\title{
GLOBALIZAÇÃO FINANCEIRA E INTEGRAÇÃ̃O DE MERCADOS FINANCEIROS NACIONAIS
}

Tese de doutorado apresentada à Faculdade de Direito da Universidade de São Paulo (FDUSP), como requisito parcial à obtenção do Grau de Doutor em Direito.

ORIENTADOR:

Prof. Dr. Umberto Celli Júnior.

Universidade de São Paulo

Faculdade de Direito

São Paulo, fevereiro de 2010 


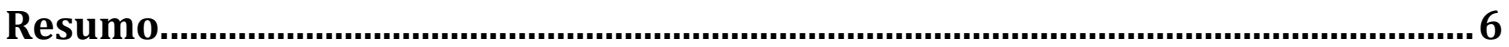

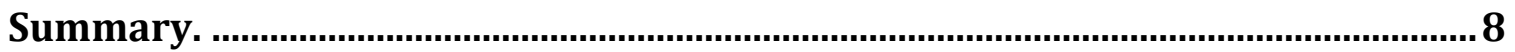

Agradecimentos.

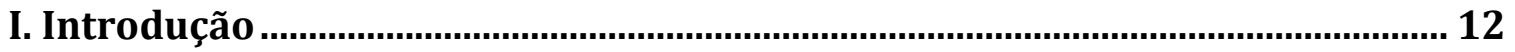

I.1. Globalização financeira e integração de mercados financeiros nacionais.......... 12

I.1.1. 0 objeto da tese: Globalização financeira e integração de mercados financeiros

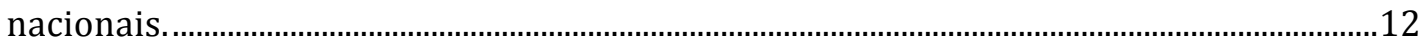

I.1.2. A tese.

I.1.3. Objetivo e proposições em que se apoiarão a tese..............................................................18

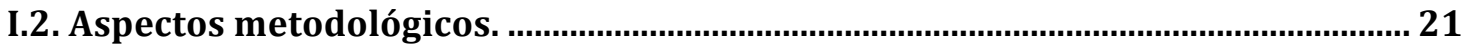

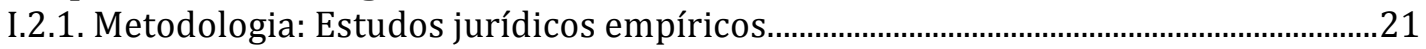

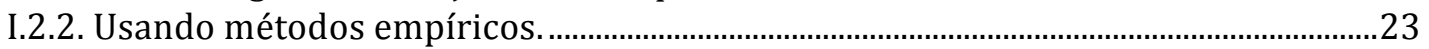

I.2.3. Parte 1 - Estrutura Jurídica da Globalização Financeira .................................................25

I.2.3.1. Capítulo 1: Governos e a formação de Sistemas Financeiros Nacionais..............................25

I.2.3.2. Capítulo 2: Governos e a internacionalização das finanças. ..................................................26

I.2.3. Parte 2 - Determinantes e feitos da globalização financeira............................................26

I.2.3.1. Capítulo 3: Análise comparativa: Processos de integração e seus efeitos.........................26

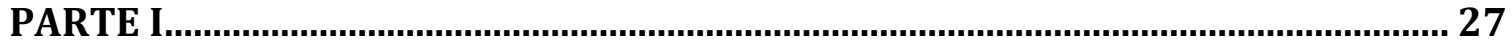

ESTRUTURA JURÍDICA DA GLOBALIZAÇÃO FINANCEIRA .................................... 27

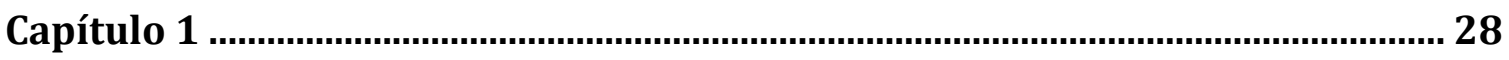

Governos e a Formação de Sistemas Financeiros Nacionais .............................. 28

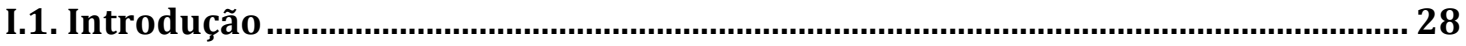

I.2. Reconstrução institucional: Casos sobre a formação de sistemas financeiros

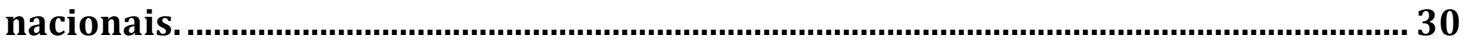

I.2.1. Pressupostos da análise.

I.2.2. 0 nascimento da atividade financeira: Os primeiros bancos e a consolidação da dominância dos governos sobre mercados nacionais. ...........................................................32 I.2.3. 0 início dos sistemas financeiros nacionais organizados pelo Estado: Bancos que

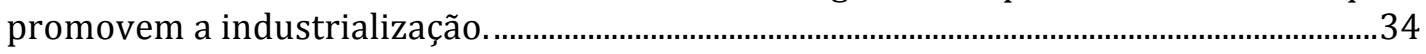

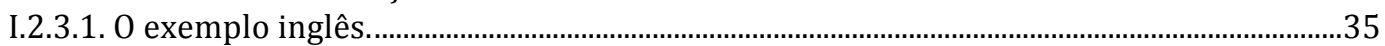

I.2.3.2. 0 exemplo francês......................................................................................................................36

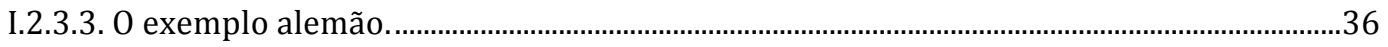

I.2.3.4. 0 exemplo norte-americano. .................................................................................................3

I.2.4. Nacionalização dos sistemas bancários: A crise dos anos 1920/1930, as guerras. e

a imposição de controles na atividade bancária e nos fluxos de capitais..............................39

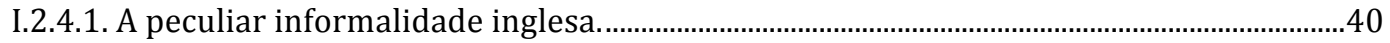

I.2.4.2. 0 dirigismo francês...................................................................................................................4

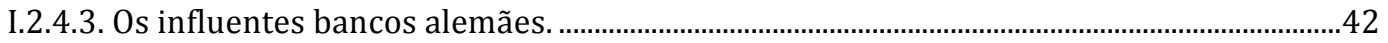

I.2.4.4. A diversidade norte-americana...........................................................................................4

I.2.5. Industrialização tardia e nacionalismo econômico: A Formação do Sistema

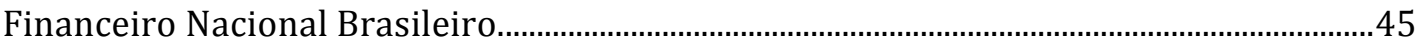

I.2.5.1. Primeira fase: Bancos a serviço da corte ..................................................................................46

I.2.5.2. Segunda fase: As primeiras instituições regulatórias............................................................46

II.2.5.3. Terceira fase: Bancos desenvolvimentistas. .........................................................................4

II.2.5.4. Quarta fase: O planejamento econômico da era militar e a intenção de se incentivarem instituições privadas. 
I.3. Moldura jurídica da formação de sistemas financeiros nacionais........................52

I.3.1. Como intervir: Instrumentos regulatórios do mercado financeiro..............................52

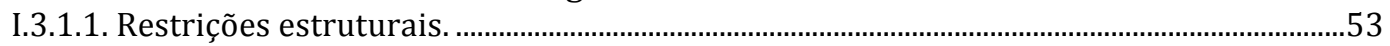

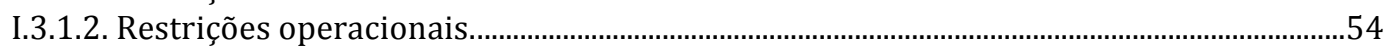

I.3.1.3. Esquemas emergenciais e de salvamento..........................................................................56

I.3.1.4. Restrições a transações internacionais....................................................................................57

I.3.!.5. Obrigações e padrões de compartilhamento de infraestrutura..........................................59

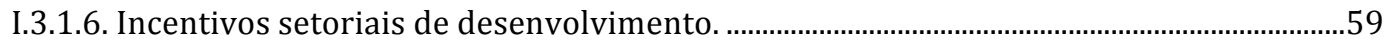

I.3.2. Por que intervir: Regulação de instituições financeiras. ...............................................60

II.3.2.1. O que fazem intermediários financeiros: Elementos de microeconomia dos intermediários financeiros...............................................................................................................61

I.3.2.2. Razões para intervenção governamental e formação de sistemas financeiros

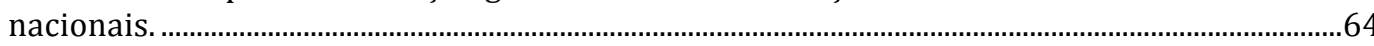

I.3.2.2.1. Consolidar a dominância governamental sobre o setor financeiro: Nacionalismo

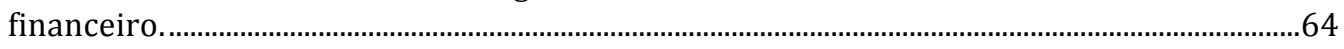

I.3.2.2.2. Implantar uma política ativa de desenvolvimento do setor financeiro. ....................65

I.3.2.2.3. Implantar políticas regulatórias de âmbito nacional. ...................................................68

I.3.2.2.4. Quadro analítico: Desenvolvimento de instrumentos de intervenção e razões

para a intervenção. ........................................................................................................................

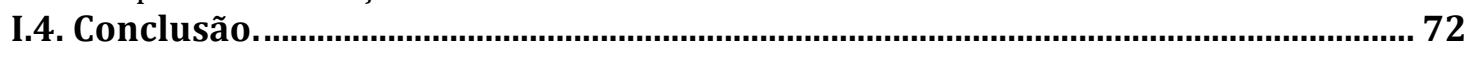

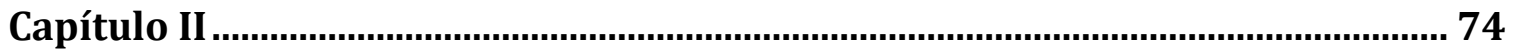

Governos e a Internacionalização das Finanças ................................................... 74

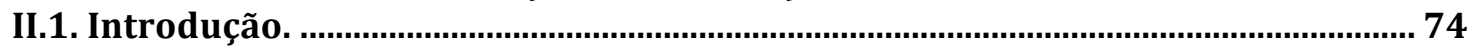

II.2. Internacionalização das finanças............................................................................... 76

II.2.1. Liberalização unilateral e reformas financeiras: O Brasil em busca de

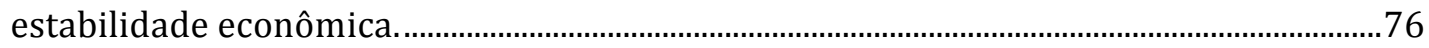

II.2.1.1. Histórico do processo de integração..................................................................................76

II.2.1.2. Objetivos do processo de integração e papéis reservados para as instituições

financeiras domésticas e estrangeiras........................................................................................... 81

II.2.1.2.1. Recapitalizar instituições domésticas problemáticas e evitar crise financeira...81

II.2.1.2.2. Recuperar a confiança dos investidores internacionais e construir uma

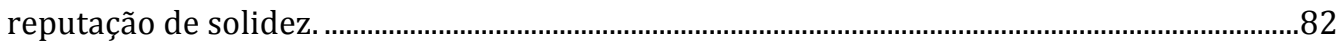

II.2.1.2.3. Fortalecer o setor financeiro privado............................................................................ 83

II.2.2. Integração financeira européia: Mercado único e a "Área Financeira Européia".84

II.2.2.1. Histórico do processo de integração. ................................................................................84

II.2.2.2. Objetivos do processo de integração e papéis reservados para as instituições

financeiras domésticas e estrangeiras................................................................................................... 88

II.2.2.2.1. Recapitalizar o sistema bancário, implantar políticas de relançamento

econômico e facilitar a estabilização econômica............................................................................8

II.2.2.2.2. Incentivar a absorção de tecnologia, desenvolvimento de novos produtos e

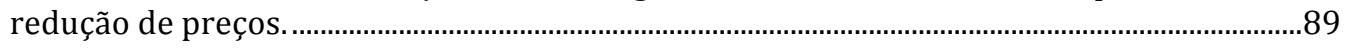

II.2.2.2.3. Aumentar a competitividade da indústria nacional frente aos estrangeiros........89

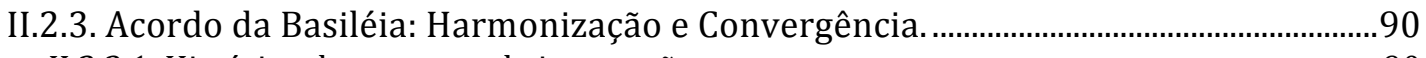

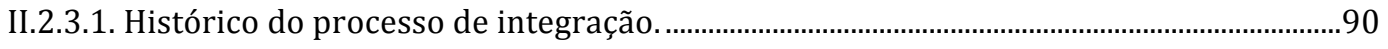

II.2.3.2. Objetivos do processo de integração e papéis reservados para as instituições

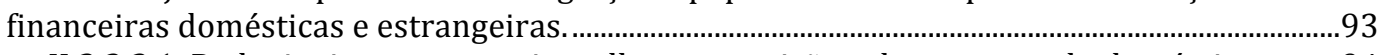

II.2.3.2.1. Reduzir riscos e garantir melhor supervisão sobre o mercado doméstico. ...........94

II.2.3.2.2. Limitar a competição entre bancos domésticos e estrangeiros..................................94

II.2.3.2.3. Reduzir o diferencial de competitividade entre bancos domésticos e

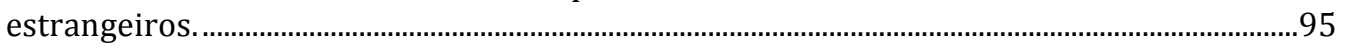

II.2.3.2.4. Melhorar a credibilidade dos bancos operando em território nacional. ................96

II.2.4. IOSCO: Cooperação entre Reguladores............................................................................97 
II.2.4.1. Histórico do processo de integração.

II.2.4.2. Objetivos do processo de integração e papéis reservados para as instituições

financeiras domésticas e estrangeiras................................................................................................100

III.2.4.2.1. Coibir fraudes e outras práticas ilícitas afetando investidores domésticos. ....100

II.2.4.2.2. Disciplinar instituições financeiras domésticas e estrangeiras. .............................101

III.2.4.2.3. Desenvolver o mercado de capitais doméstico e instituições regulatórias,

melhorando sua credibilidade, profundidade e integridade.....................................................102

II.2.5. Acordo sobre Serviços Financeiros na OMC: Integração via comércio internacional.

II.2.5.1. Histórico do processo de integração. ....................................................................................103

II.2.5.3. Objetivos do processo de integração e papéis reservados para as instituições

financeiras domésticas e estrangeiras.

II.2.5.2.1. Reduzir barreiras para fluxos de capitais e operação transfronteiriça de instituições financeiras, conseguir maior acesso a mercados estrangeiros para instituições financeiras domésticas..

II.2.5.2.2. Expor instituições financeiras domésticas à competição estrangeira, incorporar melhores práticas e tecnologia bancária..

II.2.5.2.3. Melhorar a credibilidade do sistema financeiro doméstico e restaurar a confiança de investidores estrangeiros, receber investimentos externos, e recapitalizar bancos domésticos..

II.3. Moldura jurídica da internacionalização das finanças........................................113

II.3.1. Como integrar mercados financeiros: Estruturas jurídicas.......................................113

II.3.1.1. Instrumentos jurídicos: Generalidades.............................................................................113

II.3.1.2. Estrutura jurídica liberalização unilateral brasileira.......................................................115

II.3.2.2.1. Convergência e adoção de padrões e práticas internacionais. ................................115

II.3.1.2.3. Abertura comercial unilateral. ......................................................................................117

II.3.1.3. Estrutura jurídica da integração européia........................................................................118

II.3.2.3.1. Harmonização regulatória.............................................................................................118

II.3.1.3.2. Autorização única: "Passaporte Europeu”.......................................................................119

II.3.1.3.3. Política comum para terceiros países. ...................................................................................120

II.3.1.3.4. Cooperação em supervisão financeira............................................................................120

II.3.1.3.5. Coordenação em supervisão financeira: Regra do país de origem........................120

II.3.1.4. Estrutura jurídica dos acordos da Basiléia............................................................................121

II.3.1.4.1. Regra de solução de conflitos de competência e jurisdição regulatória e de supervisão. ................................................................................................................................... 121

II.3.1.4.2. Harmonização regulatória e de padrões de supervisão............................................123

II.3.1.4.3. Cooperação em matéria regulatória e de intercâmbio de informações. ..............123

II.3.1.5. Estrutura jurídica da cooperação regulatória na IOSCO.................................................125

II.3.1.5.1. Obrigação de sigilo e limitação de uso das informações recebidas e enviadas. 125

II.3.1.5.2. Harmonização de procedimentos. ...............................................................................126

II.3.1.6. Estrutura jurídica da abertura comercial de serviços financeiros na OMC.................127

II.3.1.6.1. O GATS, suas regras e princípios fundamentais: Não-discriminação e reciprocidade. ...................................................................................................................... 127

II.3.1.6,2. Regras procedimentais, mandato negociador permanente e liberalização

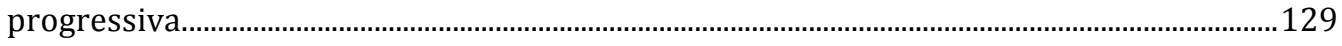

II.3.1.6.3. Subsetores, modos de prestação e listas de compromissos. ....................................131

II.3.1.6.4. Regras especiais: O Anexo sobre Serviços Financeiros. .........................................133

II.3.1.6.5. O Entendimento sobre os Compromissos em Serviços Financeiros......................136

II.3.1.6.6. Segundo e Quinto protocolos: Listas de compromissos em serviços financeiros.

II.3.2. Por que integrar mercados: Modernização e crise........................................................137

II.3.2.1. Modernização, competitividade, e estratégias de desenvolvimento..............................138

II.3.2.2. Crise financeira, regulação prudencial, estratégias de estabilização e proteção da integridade do mercado. 
II.3.2.3. Quadro Analítico: Processos de integração financeira e suas razões. .

II.4. Conclusão.

PARTE 2

EFEITOS DA GLOBALIZAÇÃO FINANCEIRA

Análise comparativa: Processos de integração e seus efeitos ..............................145

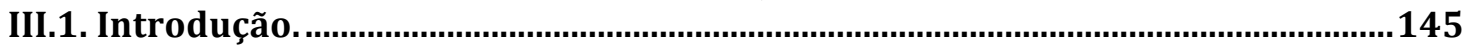

III.2. Revisão de literatura: Determinantes e efeitos da globalização financeira. .146

III.3. Formulação do modelo de analítico. ....................................................................151

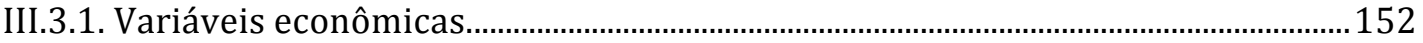

III.3.1.1. Variáveis macroeconômicas tradicionais. ......................................................................152

III.3.1.2. Indicadores setoriais bancários...................................................................................152

III.3.1.3. Indicadores setoriais de mercado de capitais..................................................................153

III.3.2. Variáveis de processos de integração financeira.......................................................153

III.3.2.1. Acordos de comércio. ........................................................................................................153

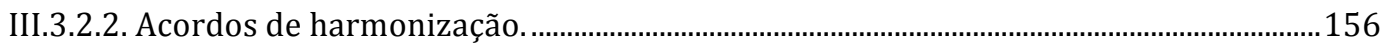

III.3.3.3. Acordos de mútuo reconhecimento..................................................................................157

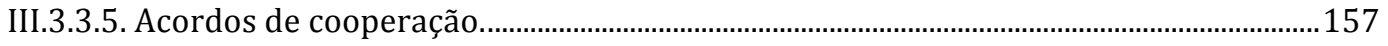

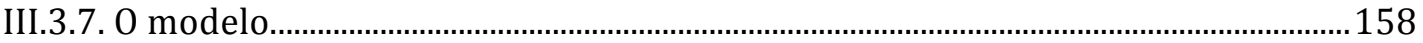

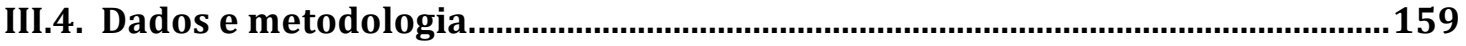

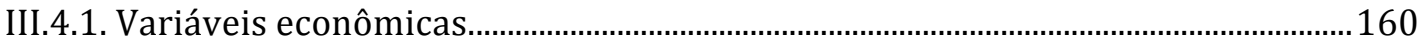

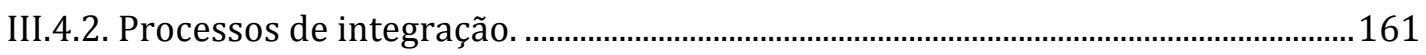

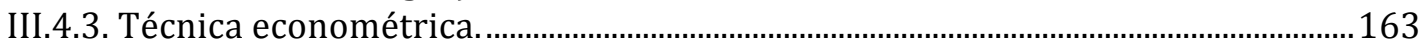

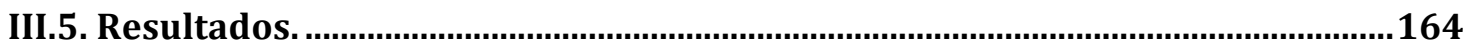

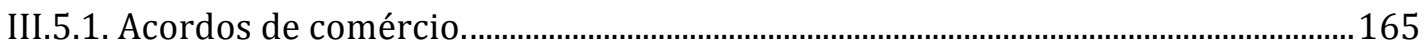

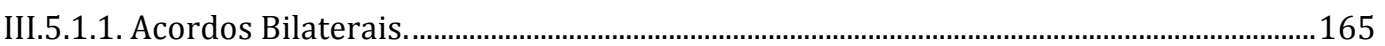

III.5.1.2. Acordos Plurilaterais........................................................................................................166

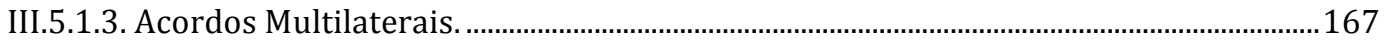

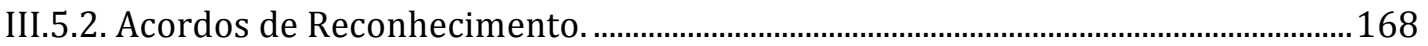

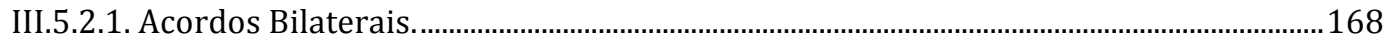

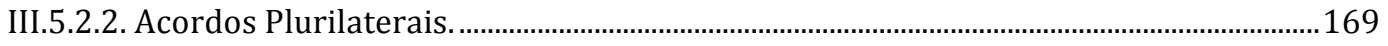

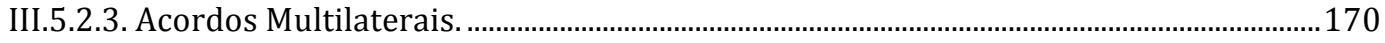

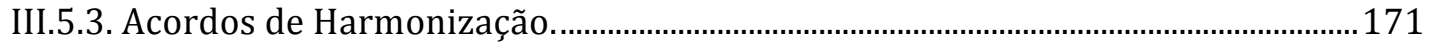

III.5.3.1. Acordos Bilaterais..........................................................................................................171

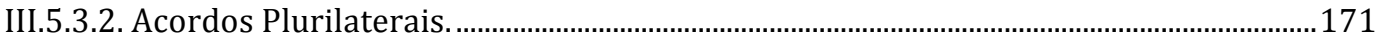

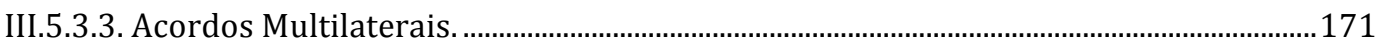

III.5.4. Acordos de Cooperação................................................................................................. 172

III.5.3.1. Acordos Bilaterais e Multilaterais.....................................................................................172

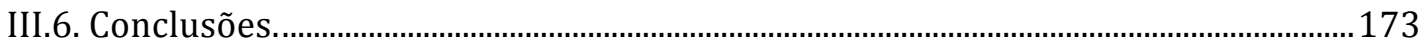

Anexo I - Lista de Acordos de Cooperação …………………………....................................174

Anexo II - Resultados das Regressões.

Considerações finais. ................................................................................................ 193

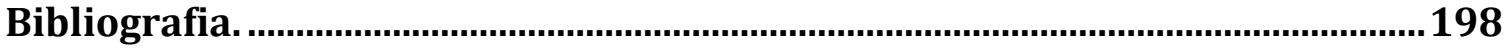




\section{RESUMO.}

O presente estudo tem dois objetivos. O primeiro (1) é substantivo: contribuir com o debate sobre globalização financeira, ajudando a nele incorporar uma dimensão que parecia um pouco fora de foco em diversas discussões - a dimensão jurídicoinstitucional empírica. O segundo (2) é metodológico, e não se relaciona diretamente com o objeto da pesquisa: ajudar a incorporar ao estudo do direito no Brasil a utilização de certas técnicas empíricas que permitiriam o exercício mais freqüente do que se será chamado aqui de "ceticismo esclarecido pela empiria" - o salutar questionamento de afirmações doutrinais peremptórias com o auxílio de evidência empírica.

Em relação ao objetivo (1), apresenta-se a seguinte tese. A globalização financeira é produto de diversos processos heterogêneos de cooperação internacional, políticas governamentais, reformas legislativas e estratégias políticas. Tais processos têm determinantes diversos, e objetivos variados, não apenas liberalização. De fato, mera liberalização unilateral não daria suporte suficiente ao aumento de fluxos financeiros transfronteiriços - a globalização só pôde e só pode ocorrer em vista da criação de uma diversidade de estruturas internacionais, incluídas aí as bilaterais, plurilaterais e multilaterais. Estas resultaram em uma densa malha jurídico-institucional que, para ser criada, demandou mudanças por diversas vezes dolorosas e custosas aos países que as implantaram, assim como grandes esforços de negociação. Somente porque existe essa malha jurídica, cuja origem é a atividade política dos governos nacionais, é que investidores e empresas financeiras puderam e podem cruzar fronteiras, deter ativos no estrangeiro, e fazê-los circular em nível global. A globalização é resultado, não da abdicação e retração dos Estados, mas do ativo engajamento de seus governos na persecução de objetivos de política pública.

Trata-se, portanto, de uma reação a interpretações concorrentes, segundo as quais a globalização financeira estaria sendo causada pela retração dos Estados Nacionais, que estariam se retirando da atividade regulatória, de forma geral, e da regulação das finanças, de formas mais específicas.

A primeira parte consiste de dois capítulos discutindo os arranjos jurídicoinstitucionais que geraram a globalização financeira. A metodologia utilizada foi 
primordialmente qualitativa. Realizaram-se reconstruções institucionais comparadas, discutindo a evolução de certos arranjos de governança do sistema financeiro. Dois conjuntos de análises de casos foram realizados: (a) uma sobre a formação comparada de Sistemas Financeiros Nacionais, e (b) outra sobre processos comparados de integração financeira.

A segunda parte consiste de um capítulo discutindo correlações entre indicadores econômicos e processos de globalização financeira. Aplicaram-se métodos econométricos sobre uma grande base de dados reunida e criada exclusivamente para esta pesquisa. 


\section{SUMMARY.}

This study has two objectives. The first (1) is substantive: to contribute to the debate on globalization by helping to incorporate to it a dimension that has been somewhat left aside in many discussions - the legal-institutional dimension. The second (2) is methodological, and not directly related to the subject of research: to help incorporating to the study of law in Brazil the use of certain empirical techniques that allow the exercise of what can be called "a skepticism enlightened by the empiricism" the healthy questioning of doctrinal statements with the aid of empirical evidence.

In relation of (1), the following thesis is advanced. Financial globalization is the product of several heterogeneous processes of international cooperation, government policies, legislative reforms and legal strategies. These processes have several determinants, and varied objectives, not just liberalization. In fact, a mere unilateral liberalization process would not give enough support to increase cross-border financial flows - globalization could only and may only occur in view of a diversity of international structures, including bilateral, plurilateral and multilateral agreements. These resulted in a dense mesh of legal and institutional structures, that to be created, demanded changes several times painful and costly to the countries that have implemented, as well as major efforts to negotiate. Only because of such legal tissue, whose origin is the political activity of national governments, is that investors and financial institutions could and can cross borders, holding assets abroad, and circulate them globally. Globalization is the result, not the abdication of the retraction, but the active engagement of governments in their pursuit of public policy objectives.

The thesis is therefore a reaction to competing interpretations, under which financial globalization was being caused by the retraction of nation states, they were withdrawing from regulatory activity, in general, and regulation of finance, more specific forms.

The first part consists of two chapters discussing the legal and institutional arrangements that led to financial globalization. The methodology was primarily 
qualitative. There were institutional compared reconstructions, discussing the evolution of certain governance arrangements of the financial system. Two sets of case studies were conducted: (a) training on a comparison of national financial systems, and (b) the other on the comparative analysis of financial integration.

The second part consists of a chapter discussing correlations between economic indicators and processes of financial globalization. Were applied econometric methods on a large database collected and created exclusively for this research. 


\section{AGRADECIMENTOS.}

A presente tese de doutorado - a bendita! - é produto de uma longa jornada que se iniciou na graduação, enfrentou a provação de dois mestrados (um no Brasil e outro nos Estados Unidos), viajou mais de uma dezena de cidades, incluindo São Paulo, Montréal, Rio de Janeiro, Brasília, Geneva, Paris, Nova Iorque, Washington, D.C., Princeton, e terminará seu percurso de gestação via eletrônica. O parto será virtual, contrações são sentidas há mais de 48 horas, mas isso é justificável porque ela terá que percorrer mais de 8 mil milhas de distância. Apertado no prazo, aos 47 minutos do segundo tempo, como sói ser.

Há fatos ainda mais surpreendentes. Nesses três anos de gestação, ela aprendey a falar três línguas fluentemente, três adicionais de forma um pouco naus precária. Conheceu pessoas de mais de 80 nacionalidades (fez quase 800 amigos no facebook). Criança travessa, brinca com conceitos jurídicos, econômicos, de ciência política e de sociologia. Foi escrita em um laptop estrategicamente posicionado no meu colo, em mesas de jantar, cozinha, sala, hotéis, cafés, bares, salas de conferência, jardins, e outros lugares ainda mais memoráveis (mas impronunciáveis). Habitou arquivos doc, docx, xls, xlsx, ppt, pptx, dta, csv, tiff, jpg, e outros não tão comuns assim.

Tem me custado neurônios, suor e lágrimas. Como da última vez que me meti a concluir algo parecido. Posso, por isso, repetir o que disse da última vez: "rendeu-me noites em claro, dias de reflexão, horas de ansiedade, infindáveis minutos de dúvida, momentos de alumbramento, segundos de inquietude e lampejos de desespero. Muito mais transpiração do que inspiração. Mas nunca arrependimento.A razão disso é uma só: não fiz só por mim ou para mim. A cada passo que dava, à medida que a pesquisa avançava, acompanhavam-me pessoas muito importantes. Nesse momento em escrevo tenho meus olhos vermelhos de cansaço, os ombros e as costas doloridos da posição extenuante de diversos dias diante da tela e do teclado. Mas me sinto cercado de olhos e mentes felizes, curiosos, ansiosos e festivos.”.

São os donos desses olhos que eu agradeço aqui.

Começo por três que me refiro como meus orientadores. Umberto Celli Júnior tem aquele idealismo e paixão, aquela fidelidade, fidedignidade e sinceridade que devem vir do lado italiano dele. Ronaldo Porto Macedo tem a clareza erudita e a persistência, o pensamento estruturado e a criatividade. Philippe Faucher tem a simplicidade, a ironia, a percepção e a facilidade de descomplicar. Nenhum podia evitar de se tornar professor. São meus exemplos mais acabados de acadêmicos e propedeutas - daqueles que seguram na nossa mão, põem-nos eu seu colo, que nos fazem rir e chorar - mas que sabem usar também da necessária faculdade repressiva.Ronaldo Porto Macedo

Uma quarta pessoa, que também deveria ser incluída nessa lista, mas que merece uma homenagem diferenciada, é Luis Fernando Schuartz. De exemplo, tornou-se símbolo, de sol tornou-se estrela. Agora me acompanha, brilhante, um pouco mais distante fisicamente, mas sempre junto no pensamento.

Os novos mentores e amigos também devem ser incluídos na lista, Merritt Fox com sua aguçada inteligência, Larry Glosten, com sua doçura e genialidade, Petros Mavroidis, com simpatia que dobra todos, e Katharina Pistor, com sua gentileza e pensamento rápido.

Merecem agradecimentos também quatro economistas amigos que me deram seu tempo e carinho: Sergio Goldbaum, Bruno Giovannetti, Eduardo Fiúza e Felipe Schwartzman.

Tive discussões longas e muito significativas com alguns professores, que sofisticaram bastante meu conhecimento de finanças e direito: John Coffee, Michael Goldstein, Craig Pirrong, Edward Greene, Ronald Gilson e Curtis Milhaupt. A eles devo o formato de muitas idéias apresentadas. Os erros ainda remanescentes são minha culpa; as idéias incorporadas, as discussões havidas e sua amizade foram presentes para mim. 
A Ricardo Terra e Marcos Nobre devo minha formação em pesquisa. Ricardo, esse mineiro que fala pouco mas diz muito, Marcos, esse líder incorporando acadêmico recebendo boêmio, foram visionários ao criarem o Núcleo Direito e Democracia no CEBRAP. Agradeço sempre que tenham me permitido fazer parte, desde 2001, desse empreendimento.

Meus grandes amigos Carlos Eduardo Batalha, Andreas Padvaiskas, Apoena Joels, Bruno Robert, Daniel Arbix, Elizabeth Fernandes, Eric Jasper, Guilherme Rafare, João Paulo Krepel, José Carlos da Matta Berardo, e Paulo Casagrande têm um coração enorme, mentes geniais e generosidade insuperável.

Compartilho com Barbara Rosenberg, Caio Mario da Silva Pereira Netto, Diogo Coutinho, Glauco Arbix, Jean Paul Veiga da Rocha, Mário Schapiro, Paulo Todescan Lessa Mattos e Rabih Nasser da visão de que o Estado continua sendo importante para o desenvolvimento. Beneficio-me das nossas discussões, leituras e projetos conjuntos. Esta dissertação é o primeiro produto da nossa convivência e amizade. Que a elas seja dedicada.

A pesquisa financiada pela Fundação Ford e desenvolvida durante os últimos sete anos no NCS - Grupo de Estudo das Negociações Comerciais sobre Serviços do IDCID e da Faculdade de Direito da USP foi o embrião de todo o trabalho desenvolvido aqui. Alberto Amaral Junior, Luiza Saito Sampaio, e Ricardo Medina Salla, vocês são geniais, obrigado pela ajuda. Ao Ricardo agradecimentos especiais por toda ajuda e pelo grande coração.

Esta pesquisa também se beneficiou imensamente da experiência que tive como integrante do Grupo Interministerial de Comércio Internacional - Seção Serviços (GICI-SV), participando das negociações sobre serviços em Genebra. Foi-me muito proveitosa a convivência e contato com os muitíssimo bem preparados diplomatas do Ministério das Relações Exteriores. Audo Faleiro permitiu-me as mais fantásticas experiências em Genebra, desde participar de sessões oficiais a jogar futebol com delegados estrangeiros. Ronaldo Costa Filho, estrategista e negociador excepcional, obrigado pela confiança depositada em mim. Michel Arslanian Neto é uma das pessoas mais incansáveis e gentis que conheço. Ernesto Henrique Fraga Araújo foi responsável por momentos memoráveis nas sessões de que participei. Rodrigo Estrela, jovem economista, além de ter se mostrado um ótimo confidente, tem um futuro brilhante na carreira.

Agradeço também as discussões que tive com outros especialistas reguladores, em Genebra, Rio de Janeiro e em Brasília. Alexandre Diniz de Freitas, Henri Eduard Stupakoff Kistler, e Marcos Pinto, Maria Helena Atrasas e Otavio Yazbek.

Encerro com os agradecimentos mais importantes (desculpas aos que vieram antes). Meus pais, Regina Mieko Sakata Mirandola, e Ademir Marcos Mirandola, meu irmão, Luis Augusto Sakata Mirandola, e minha gatchinha, Angela Fonseca suportam o grande ônus de serem aqueles com quem conto por toda a vida. São também os que me dão maior felicidade. Essa dissertação é produto de sua persistência e apoio, 


\section{INTRODUCÃ̃O}

"Ainda assim, os novos modelos econômicos em direção aos quais estamos nos dirigindo, são, em essência e por natureza, experimentos. Não temos idéias claras em nossas mentes sobre o que desejamos com exatidão. Devemos descobrir enquanto nos movemos, e temos que moldar nossa matéria prima de acordo com nossa experiência. Para esse processo, críticas severas, duras e sem remorso são condições sine qua non para eventual sucesso. Precisamos da colaboração dos espíritos mais brilhantes de nossa era." John Maynard Keynes, National Self-Sufficiency ${ }^{1}$.

\section{I.1. GLOBALIZAÇ̃̃O FINANCEIRA E INTEGRAÇÃO DE MERCADOS FINANCEIROS}

\section{NACIONAIS.}

\section{I.1.1. O OBJETO DA TESE: GLOBALIZAÇÃO FINANCEIRA E INTEGRAÇÃO DE MERCADOS FINANCEIROS NACIONAIS.}

Paul Krugman, em seu livro sobre os eventos de $2008^{2}$, descreve como a crise norte-americana acabou se tornando um problema mundial. Em sua visão, o grande culpado seria o que economistas chamam "globalização financeira", uma "transformação no caráter do sistema financeiro que aconteceu nos últimos quinze anos, principalmente

\footnotetext{
${ }^{1}$ (Keynes 1933).

2 Vide (Krugman 2008, 165-180).
} 
depois da crise asiática"3. Tal estado de coisas, segundo o autor, caracteriza-se principalmente por investidores de um país possuírem muitos ativos financeiros em outros países, ou seja, por um descolamento entre a localização dos ativos financeiros e a nacionalidade de seus proprietários. Essa definição do fenômeno, segundo a qual globalização financeira é um conjunto de transformações na organização da economia mundial em que a propriedade de ativos financeiros não mais segue uma lógica territorial, será a utilizada por esta tese.

Em verdade, a globalização financeira na forma mencionada por Krugman é um fato. As atividades financeiras de empresas multinacionais e investidores internacionais tomaram nova dimensão. No intervalo de uma década e meia o fluxo mundial de investimentos externos diretos passou aumentou quase oito vezes, saltando de USD 266 bilhões em 1994 (menos 1\% do PIB mundial) para USD 2.107 bilhões em 2008 (4\% do PIB mundial). O fluxo estrangeiro de capitais em bolsa de valores multiplicou-se na mesma proporção, crescendo de USD 421 bilhões em 1994 (1.5\% do PIB mundial) para USD 3.614 bilhões em 2007 (6.5\% do PIB mundial). Os quadros abaixo ilustram essas transformações.

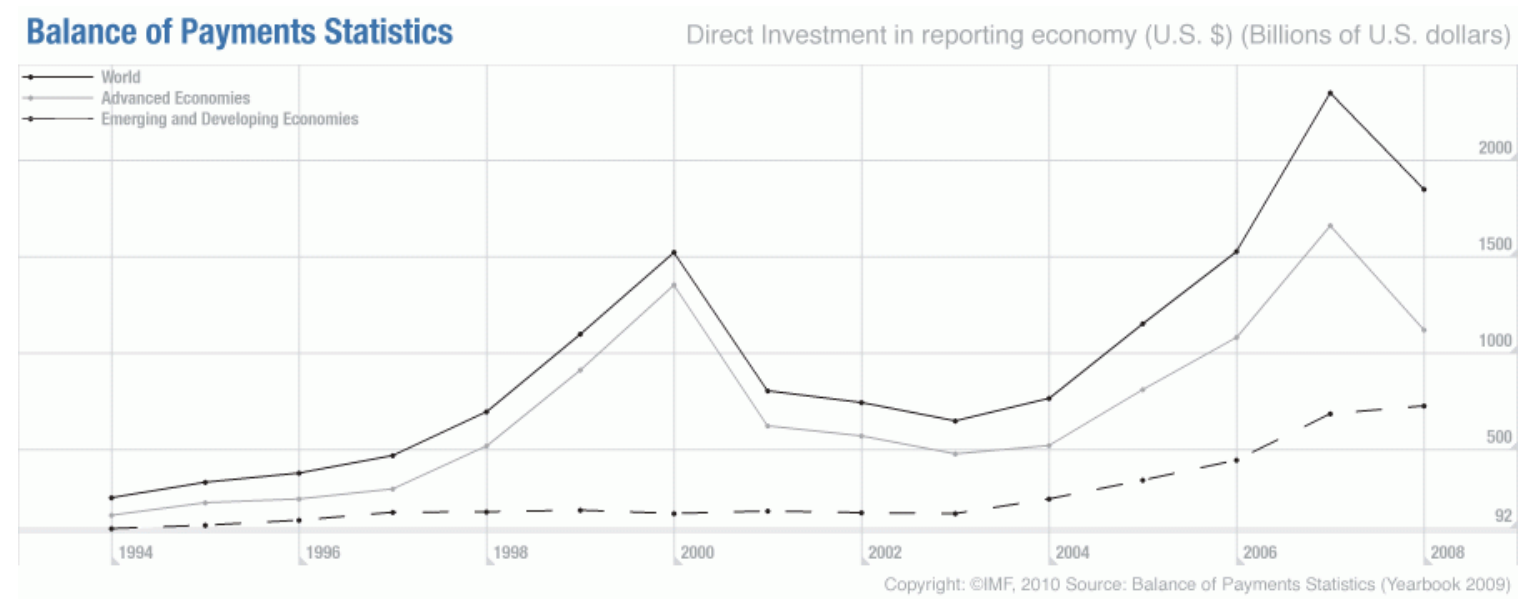

\footnotetext{
${ }^{3}$ Tradução livre. No original: "transformation in the character of the financial system over the past fifteen years, with much of it taking place after the Asian crisis". Vide (Krugman 2008, 177).
} 


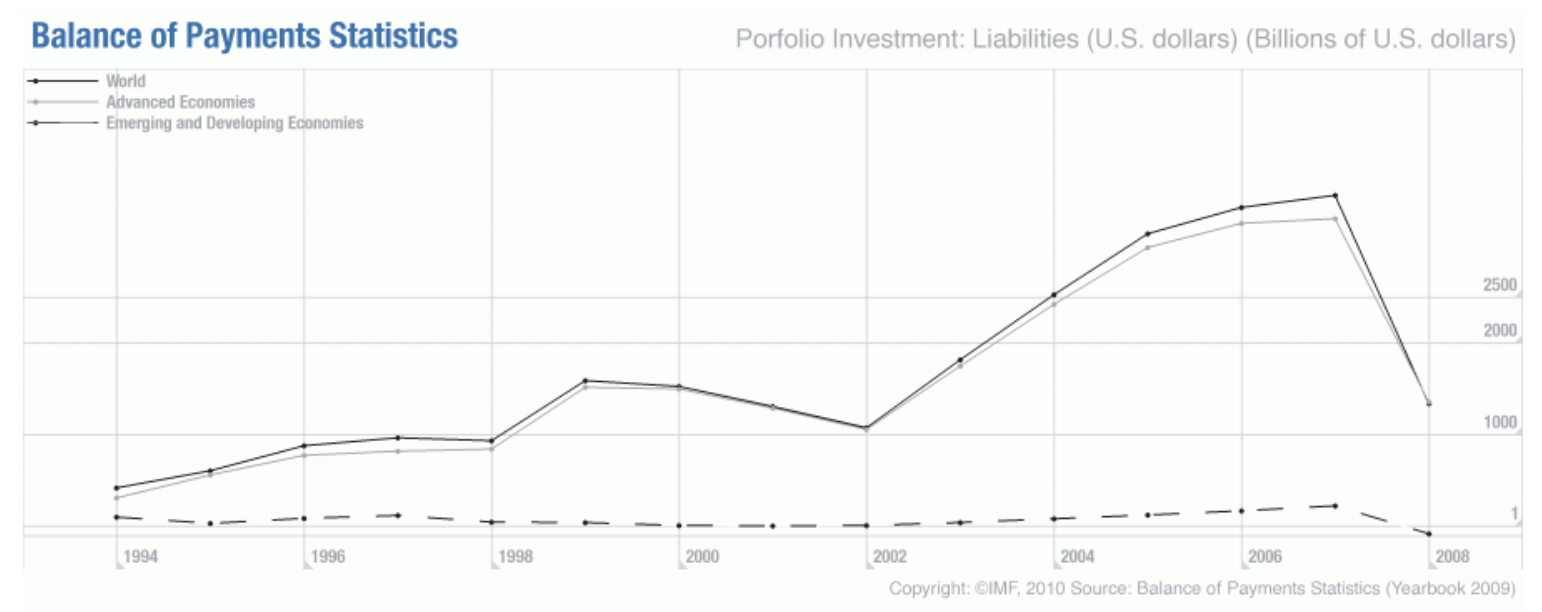

O mundo dos fluxos e instituições financeiros globais tem se ampliado de forma considerável em tempos recentes.Todavia, do mesmo modo que a globalização existe e é um fato, também existem alguns mitos, ou, ao menos, interpretações parciais e incompletas do fenômeno. O principal deles, aquele contra o qual a presente tese se insurge, é o de que a globalização financeira é causada por um (e apenas um) processo homogêneo de reformas liberalizantes, entendidas como retração dos Estados Nacionais ${ }^{4}$ no que tange a regulação dos assuntos financeiros. Mais especificamente, de que o grande mercado financeiro global, ainda em processo de formação, está a produzir-se por default, pela ausência de regras, pela desregulamentação das finanças. Sua gestação estaria sendo levada adiante primordialmente pelo mercado, e os governos nacionais teriam um papel muito mais reativo: a política teria passado ao segundo plano, e os governos teriam abdicado de grandes intervenções.

Esse mito repousa sobre três asserções que são, em grande medida, falhas ou incompletas. As duas primeiras asserções têm natureza explicativa. Segundo a (1) primeira, durante as décadas de 1980 e 1990, um número pequeno de países embarcou

\footnotetext{
${ }^{4}$ No original em inglês, retreat of the State. A expressão "retração do Estado" ou "retirada do Estado" foi cunhada por Susan Strange na segunda metade da década de $1990 \mathrm{em}$ um controverso e influente livro que almejava explicar as grandes mudanças por que estavam passando as relações econômicas internacionais (Strange 1996). Segundo a autora, globalização implicaria o declínio da autoridade dos Estados, por um lado, e a limitação da política pelas forças dos mercados, por outro. Poder e a autoridade legítima no âmbito da economia internacional estariam migrando dos governos nacionais para entidades não governamentais. Casos trabalhados pela autora incluem telecomunicações, crime internacional (a máfia), as seguradoras, as big six empresas da contabilidade, cartéis, e os econocratas de organizações internacionais.
} 
numa série de experimentos institucionais, implementando reformas liberalizantes que levaram a um aumento do seu crescimento econômico. Tais experimentos, pioneiros, tinham como principal característica sua natureza unilateral: teriam sido realizados sem o suporte de outros países e sem a criação de estruturas jurídicas internacionais. Segundo a evidência empírica reunida inicialmente, haveria certa correlação positiva entre abertura unilateral da conta de capital e crescimento econômico ${ }^{5}$.

A segunda (2) asserção implica interpretar os diversos e concomitantes processos de reformas financeira como sendo uniformes nos diversos países, e homogêneos nos resultados. Em outras palavras, é dizer que governos nacionais estão a fazer as mesmas coisas, do mesmo modo, com as mesmas intenções, buscando os mesmos objetivos. A diferença, portanto, estaria no grau de perfeição com que atingem seus objetivos. Preferencialmente, no quão mais eficientemente conseguem implantar o programa de liberalização receitado, pré-estabelecido e consensual, de modo a abrir seu setor financeiro para estrangeiros, e, com isso, fazer com que suas economias cresçam ${ }^{6}$.

A terceira (3) pretende-se por normativa e afirma que existe (ou deveria existir) apenas um modelo de reformas financeiras a ser seguido. Segundo ela, as experiências de integração financeira que foram bem-sucedidas nos últimos 15 anos teriam seguido uma forma pré-determinada. Esse modelo inclui quatro passos: (i) estabilizar a economia, (ii) abrir o país para fluxos comerciais, (iii) desregulamentar a conta de capitais (liberalizar investimentos) e (iv) desregulamentar a conta corrente (liberalizar pagamentos e câmbio $)^{7}$. As experiências mal-sucedidas foram aquelas que não seguiram tais passos. Autores adeptos desse modelo divergiriam apenas quanto à necessidade de se seguir uma

\footnotetext{
${ }^{5}$ Vide (R. I McKinnon 1973; Diaz-Alejandro 1981; Ronald I. McKinnon 1981; Edwards and Wijnbergen 1986; Ronald I. McKinnon 1991)

${ }^{6}$ A base intelectual dessa linha de argumentação está deita raízes em duas linhas de pesquisa que floresceram nos anos 1990: (i) os chamados estudos sobre finanças e crescimento, e os (ii) estudos sobre repressão financeira. Tais estudos assumem que governos estão a implantarreformas financeiras para buscar crescimento econômico. Testam, então, o sucesso dessas ações, tentando estabelecer uma correlação entre taxas de crescimento e o progresso de reformas financeiras. Vide, por exemplo, (Stiglitz 2000; Obadan 2006; Klein and Olivei 2008; E. S Prasad and Rajan 2008; Ayhan Kose, Eswar S. Prasad, and Terrones 2009; Mishkin 2009; Abbott, Andersen, and Tarp; Eun and Jinsoo Lee; Umutlu, Akdeniz, and Altay-Salih 2009).

${ }^{7}$ A discussão sobre essas quatro grandes liberalizações às vezes é confundida com o chamado Consenso de Washington. Vide (Williamson 1990). Na verdade, ela o antecede e tem vida própria na literatura de finanças internacionais. Data da década de 1970, quando das primeiras iniciativas de resregulamentação da conta de capitais no âmbito dos países da Organização de Cooperação e Desenvolvimento Econômico (OCDE). Vide, por exemplo, (Gottschalk 2000).
} 
seqüência na implementação dessas reformas. Para alguns, a seqüência não importa contanto que as reformas sejam feitas ${ }^{8}$; para outros, seqüenciamento é crucial para os resultados pretendidos ${ }^{9}$. Ambas as linhas, todavia, convergem em três pontos: (a) no diagnóstico de que as reformas são necessárias, e, logicamente, levarão a taxas maiores de crescimento econômico; (b) na análise de que tais reformas compõem um caminho unívoco que, como matéria de política pública, deve ser trilhado; (c) no postulado de que se trata de um conjunto de reformas domésticas que podem ser implantadas unilateralmente, prescindindo de acordos e cooperação internacionais para darem certo.

\section{I.1.2. A TESE.}

A tese a ser apresentada na presente pesquisa é uma reação a esse mito. Afirmarse-á que a globalização financeira é produto de diversos processos heterogêneos de cooperação internacional, políticas governamentais, reformas legislativas e estratégias políticas. Tais processos têm determinantes diversos, e objetivos variados, não apenas liberalização. De fato, mera liberalização unilateral não daria suporte suficiente ao aumento de fluxos financeiros transfronteiriços - a globalização só pôde e só pode ocorrer em vista da criação de uma diversidade de estruturas internacionais, incluídas aí as bilaterais, plurilaterais e multilaterais. Estas resultaram em uma densa malha jurídicoinstitucional que, para ser criada, demandou mudanças por diversas vezes dolorosas e custosas aos países que as implantaram, assim como grandes esforços de negociação. Somente porque existe essa malha jurídica, cuja origem é a atividade política dos governos nacionais, é que investidores e empresas financeiras puderam e podem cruzar fronteiras, deter ativos no estrangeiro, e fazê-los circular em nível global. A globalização é resultado, não da abdicação e retração dos Estados, mas do ativo engajamento de seus governos na persecução de objetivos de política pública.

Tem-se, destarte, que as três asserções mencionadas acima, de que (1) evidência empírica mostraria que liberalização gera desenvolvimento, de que (2) os países que tiveram sucesso com a liberalização seguiram um caminho único, uniforme nas causas e

\footnotetext{
${ }^{8}$ Vide, por exemplo, (Dornbusch 1998).

${ }^{9}$ Vide, por exemplo, (Edwards 1989; Falvey and Kim 1992; Fischer 1998; B. Eichengreen and Mussa 1998; Kireyev 2002).
} 
homogêneo nos resultados, e de que (3) existiria um receituário simples e único que poderia ser prescrito para diversos países, não devem ser levadas às últimas conseqüências.

Em relação à (1) primeira asserção (explicativa), um estudo mais detalhado dos diversos processos de integração que perfizeram e perfazem a estrutura jurídicoinstitucional da globalização financeira permitiria afirmar que (a) não há um único objetivo o qual todos os processos de integração perseguem, e que (b) há muita heterogeneidade nos resultados por eles conseguidos. Governos nacionais permitem e incentivam que capitais e instituições estrangeiras adentrem o território nacional também por motivos outros que o de aumentar a taxa de crescimento. Do mesmo modo, ajudam finanças e instituições financeiras domésticas a cruzarem as fronteiras nacionais por diversas razões. Isso explica, por exemplo, por que certos dados em respeito a processos de integração financeira parecem contraditórios, como: por que países que liberalizam a conta de capital tornam-se potencialmente mais instáveis ${ }^{10}$; por que países que, ao contrário, impõem restrições cambiais em tempos de crise estabilizam-se mais rápido ${ }^{11}$; por que governos que enfrentam crises financeiras, ao invés de proteger suas instituições financeiras com barreiras protecionistas, assinam acordos de abertura comercial expondoas ainda mais ${ }^{12}$. Ficarão desapontados tanto aqueles que pensam que globalização só causa mais crescimento como os que imaginam que ela só é utilizada por governos nacionais como fagulha para o desenvolvimento.

Em relação à (2) segunda asserção (explicativa), tem-se a dizer que a globalização financeira foi e vem sendo causada, ao contrário do que se sugeriu anteriormente, por uma pluralidade de processos de integração. Para os efeitos da presente pesquisa, serão chamados processos de integração financeira o conjunto de políticas públicas e reformas institucionais em que governos nacionais, visando a construir uma maior integração de seus mercados financeiros domésticos com mercados estrangeiros, negociam acordos e assumem obrigações que implicam modificações em seu regime regulatório. A formação

\footnotetext{
${ }^{10}$ Vide, por exemplo, (Edwards 2009; Henry 2007; Bekaert and Harvey 2003) discutindo situações em que a abertura da conta de capitais criou ameaças à estabilidade.

${ }^{11}$ Este foi o caso, por exemplo, da Malásia no auge da Crise Asiática, que impôs restrições temporárias à saída de capitais. Vide (Rodrik and Arvind Subramanian 2009)

${ }^{12}$ Autores defendem que o principal fator impulsionando a assinatura do Acordo sobre Serviços

Financeiros da OMC em 1997 foi a crise asiática. Vide (Kireyev 2002; Dobson, Pierre, and Jacquet 1998).
} 
da "Área Financeira Européia", os Acordos da Basiléia, o Memorando Multilateral de Entendimento da IOSCO, o Acordo de Serviços Financeiros na OMC - todos são processos de integração financeira. Liberalização financeira unilateral também se inclui nessa lista e nada mais é do que apenas um dentre vários tipos de processos de integração.

Em relação à (3) terceira (normativa), por causa da pluralidade de processos de integração financeira que dão suporte à globalização, e por causa da diversidade de objetivos que governos perseguem quando decidem permitir que estrangeiros adquiram ativos no mercado doméstico, ou que nacionais adquiram ativos no exterior, não se pode dizer, nem que liberalização seja sempre o melhor procedimento, nem que deve ou não seguir uma seqüencia qualquer. De fato, estudos empíricos parecem corroborar essa posição, indicando que os resultados de processos unilaterais de abertura financeira são mistos, e que a correlação entre liberalização e crescimento parece ser muito fraca, ou, mesmo, inexistente ${ }^{13}$. Isso faz pensar que: (a) caso governos nacionais desejem crescimento econômico, talvez a liberalização financeira unilateral não seja necessariamente o melhor instrumento; (b) não parece haver um caminho unitário e unívoco em relação à liberalização financeira; (c) talvez sejam necessários outros arranjos que não a reforma unilateral para fomentar crescimento econômico. Desapontarse-á quem pensa que globalização necessariamente deve levar a um aumento do Produto Interno Bruto.

\section{I.1.3. OBJETIVO E PROPOSIÇÕES EM QUE SE APOIARÃO A TESE.}

Para entender por que instituições financeiras passaram a cruzar com tanta freqüência as fronteiras nacionais, deixando mercados domésticos e aventurando-se em mercados estrangeiros, é necessário entender algumas coisas: por que, em primeiro lugar, elas passaram tanto tempo adstritas a seus mercados de origem; por que, em segundo, elas passaram a buscar clientes estrangeiros e a operar no exterior; como, em linhas gerais, ocorreram essas transformações; e quais os possíveis resultados e conseqüências dessas mudanças. Destarte, entender essa relação de controle que Estados almejam ter

\footnotetext{
${ }^{13}$ Para duas revisões críticas de literatura bastante recentes e cuidadosas indicando a baixa correlação entre crescimento econômico e abertura financeira vide (Rodrik and Arvind Subramanian 2009; Kose et al. 2006).
} 
sobre seu setor financeiro, sua natureza, seus instrumentos e seus usos, é o objetivo fundamental subjacente à tese.

A explicação sugerida aqui será baseada em três proposições principais.

- Proposição P1. Sistemas Financeiros Nacionais, arranjos jurídico-institucionais dominantes durante todo o período compreendido entre o final do século XIX e início do século $X X$, são conseqüencias da atividade dos Estados na consolidação de sua dominância sobre mercados nacionais, e no apoio ao desenvolvimento industrial.

Explicação E1. Nos séculos XIX e XX, os principais motivos para que governos nacionais centralizassem seus mercados financeiros e os organizassem na forma de Sistemas Financeiros Nacionais eram a consolidação de sua dominância sobre mercados nacionais e o apoio à industrialização. Eram características da época a utilização do setor financeiro para a implementação de políticas de desenvolvimento de mercados e o nacionalismo econômico. Os principais instrumentos jurídicos cultivados e utilizados pelos governos nacionais para regular as atividades das instituições financeiras, portanto, eram instrumentos de controle de mercado $^{14}$ : (i) restrições estruturais, (ii) restrições operacionais, (iii) esquemas emergenciais e de salvamento de instituições financeiras, (iv) restrições a transações internacionais, (v) obrigações e padrões de compartilhamento de infra-estrutura, e (vi) incentivos setoriais de desenvolvimento.

- Proposição P2. Processos de integração financeira internacional, arranjos jurídicoinstitucionais que se formaram e se fortaleceram a partir do final do século $X X$, são conseqüencias da atividade dos Estados nacionais de apoio à modernização, desenvolvimento e aumento de competitividade de setor financeiro doméstico, e de combate a crises, estratégias de estabilização, e proteção da integridade do mercado. Explicação E2. No período que se iniciou na segunda metade do século XX, os governos nacionais permitiam a operação de instituições domésticas no estrangeiro e de instituições estrangeiras em território nacional em dois casos principais: (i) para implantar políticas de modernização, desenvolvimento e competitividade, e (ii) para debelar crises financeiras, estabilizar e proteger a integridade do mercado doméstico. Era característica da época utilizar a exposição de instituições doméstica às

\footnotetext{
${ }^{14}$ Isso será discutido abaixo. Vide Capítulo 1.
} 
estrangeiras, seja em mercado domésticos, seja em mercados internacionais, para disciplinar as entidades nacionais. Os principais instrumentos jurídicos desenvolvidos e utilizados para esses fins são, portanto, instrumentos de integração financeira ${ }^{15}$ : (i) acordos de comércio internacional, (ii) acordos de harmonização regulatória, (iii) mútuo reconhecimento, (iv) acordos de cooperação, e (v) convergência regulatória.

- Proposição P3. Arranjos jurídico-institucionais similares no ponto de vista formal podem ter conseqüencias diferenciadas dependendo do contexto em que são invocados, e, por isso, podem ser usados por governos nacionais de forma variada. Do mesmo modo, arranjos diferentes do ponto de vista formal podem ter conseqüencias semelhantes.

Explicação E3. A forma não necessariamente anda de mãos dadas com o efeito prático no caso de arranjos jurídico-institucionais. Um mesmo instrumento jurídico pode ser utilizado de maneira completamente diversa por países operando em contextos dissimilares. Assim, por exemplo, enquanto uma economia desenvolvida pode querer usar a assinatura de acordos de comércio para barganhar garantias de acesso ao mercado do parceiro comercial para suas instituições financeiras domésticas, economias emergentes podem querer assiná-los para atrair investimentos. Do mesmo modo, instrumentos jurídicos diferentes podem ser usados para obter os mesmos resultados. É o caso, por exemplo, da regulação prudencial de bancos: um regulador pode impor requisitos de capital mais altos para seus bancos, de modo a evitar riscos excessivos. Outro regulador pode preferir determinar a participação obrigatória num esquema de um seguro instituído na forma de um fundo garantidor de crédito, por exemplo. No que tange a função prudencial, ambos os arranjos teriam resultados parecidos, diferindo todavia nos incentivos criados a cada instituição.

\footnotetext{
${ }^{15}$ Isso será discutido abaixo. Vide Capítulo 2.
} 


\section{I.2. ASPECTOS METODOLÓGICOS.}

\section{I.2.1. METODOLOGIA: ESTUDOS JURÍDICOS EMPÍRICOS.}

A presente tese preocupar-se em estudar processos jurídicos de integração financeira internacional. Metodologicamente, a pesquisa utilizará, entre outros, métodos empíricos de investigação, e filiar-se à crescente literatura chamada "estudos jurídicos empíricos".

Thomas Miles e Cass Sunstein (2008), em um artigo discutindo novas tendências no estudo do direito, notam que a academia jurídica norte-americana está num momento de "florescimento em larga escala de estudos quantitativos de fatos e resultados"16. Tais estudos produziram um movimento que os autores pretendem ver chamado de "novo realismo jurídico". Os mesmos autores aproveitam a feliz formulação de Erlanger, Garth, Larson, Mertz, Nourse e Wilkins (2005), e definem esse novo realismo jurídico como uma abordagem que "traz a teoria jurídica para perto da pesquisa empírica de modo a construir fundações mais sólidas para a compreensão do direito e formulação da política jurídica.". ${ }^{17}$

Esse novo tipo de realismo jurídico bebe nas águas da tradição do antigo realismo jurídico, corrente nascida na virada do século 20 com Holmes, Cardoso e Pound trabalhando nas escolas de direito de Columbia e Yale ${ }^{18}$, e revigorada por um curto período de tempo, no pós-guerra, por Myers MacDougal e a chamada Escola de New Haven $^{19}$. Como diferencial ${ }^{20}$, todavia, está o forte caráter empírico de suas pesquisas: o novo realismo é, na verdade, um "novo empiricismo", e está calcado necessariamente na realização de pesquisas com coleta de dados, descrição de fatos, uso de estatísticas e verificação de resultados e conseqüências. Congrega uma plêiade de abordagens e técnicas empíricas que são empregadas no estudo de fenômenos jurídicos, metodologias

\footnotetext{
${ }^{16}$ No original em inglês: "We are in the midst of a flowering of 'large-scale quantitative studies of facts and outcome.". Vide (Miles and Sunstein 2008, 831)).

${ }^{17}$ No original em inglês: "New legal realist scholars bring together legal theory and empirical research to build a stronger foundation for understanding law and formulating legal policy.". Vide (Erlanger et al. 2005, 337).

${ }^{18}$ Vide (Horwitz 2006, 169-192; Macaulay 2005, 369).

${ }^{19}$ Vide (Heise 2002, 822; Mirandola 2006, 26 e ss).

${ }^{20}$ Para uma comparação entre o novo e o antigo realismo, vide (Macaulay 2005).
} 
quantitativas e qualitativas utilizadas em ciências sociais - principalmente na economia, na sociologia, na ciência política e na psicologia.

Autores como Reise (2002: 824 e ss.) notam a força que tais abordagens têm adquirido, tanto em termos de influência sobre o meio acadêmico como sobre os tribunais. Revistas jurídicas tradicionais têm cedido cada vez mais espaço a estudos empíricos, e faculdades de direito de renome têm patrocinado o surgimento de novos títulos $^{21}$ e centros de pesquisa ${ }^{22}$. Tais revistas galgaram colocações significativas entre os periódicos de maior impacto nos Estados Unidos, todos se classificando atualmente entre os mais $\operatorname{citados}^{23}$. A literatura desenvolvida também impressiona, seja em vista de seu volume, seja por causa da qualidade. Por exemplo, a base de dados do Grupo de Pesquisa Empírica da Escola de Direito da Universidade da Califórnia registra que 792 artigos empíricos foram publicados no período de 2001 a $2008^{24}$.

Igualmente, em relação à influência de pesquisas empíricas nos tribunais, Reise (2002: 831 e ss.) também nota que é cada vez mais freqüente que juízes façam apologias públicas do recurso a técnicas empíricas de investigação quando tomam decisões. Um dos exemplos emblemáticos mencionados pelo autor é o comportamento da Suprema Corte norte-americana na decisão do caso United States v. Leon ${ }^{25}$ que versava sobre a constitucionalidade de buscas e apreensões. Em tal caso, após rever a literatura e notar a insuficiência de estudos empíricos que embasassem qualquer decisão, o Ministro Blackmun opinou que a força das conclusões do tribunal seria tão grande quanto a de seus pressupostos, e, se estes se mostrassem empiricamente frágeis no futuro, a Suprema Corte deveria revisitar o caso e decidir de acordo com os eventuais pressupostos novos.

Outrossim, grande tem sido a influência das abordagens empíricas no outro lado do Atlântico. A fundação britânica Nuffield encomendou em 2006 um estudo sobre como melhorar a compreensão do funcionamento do direito. Tal estudo, realizado sob a

\footnotetext{
${ }^{21}$ São citados como exemplos o Journal of Legal Studies, o Journal of Law and Economics, o Journal of Law, Economics \& Organization, a Law \& Society Review, a revista Law and Social Inquiry, e o Journal of Empirical Legal Studies.

${ }^{22}$ Por exemplo, as faculdades de direito das universidades de Columbia, Chicago, Harvard, Northwestern, Wisconsin, Cornell, Illinois, Califórnia (Los Angeles).

${ }^{23}$ Vide ranking de periódicos de maior impacto em http://lawlib.wlu.edu/LJ/index.aspx, visitado em $20 \mathrm{de}$ janeiro de 2009.

${ }_{24}$ Vide http://www.law.ucla.edu/home/apps/els/, visitado em 20 de janeiro de 2009.

${ }^{25}$ United States v. Leon, 468 U.S. 897 (1984).
} 
liderança de especialistas do governo britânico, da University College London (UCL), e da Queen's University Belfast ${ }^{26}$, envolveu mais de 50 acadêmicos das mais importantes universidades britânicas. Concluíram que, tendo em vista a importância e o valor crescentes das pesquisas empíricas para o judiciário, legisladores, operadores do direito e acadêmicos, medidas de política pública deveriam ser tomadas de modo a incentivar a preparação de pesquisadores aptos a conduzir estudos interdisciplinares calcados na produção e análise de dados jurídicos. Entre as recomendações feitas, estão maior investimento em ensino, financiamento de pesquisas, cooperação entre departamentos de ciências sociais e direito nas universidades, e ênfase na contratação de professores com bagagem empírica.

\section{I.2.2. USANDO MÉTODOS EMPÍRICOS.}

Sistemas financeiros, direito bancário e direito dos mercados de capitais mundo afora têm peculiaridades. Por conseguinte, processos internacionais de integração financeira padecem das mesmas características. Combinações institucionais dificilmente são iguais e a história aponta para diferentes opções políticas, idiossincrasias nacionais e locais, políticas públicas e tradições locais. Em conseqüência, compreender os determinantes de um processo de integração financeira pode ser um trabalho bastante complexo para juristas que pretendem entender os efeitos de diferentes arranjos de governança. Metodologias variadas existem e estão disponíveis para isso. De modo geral, tais metodologias são divididas em dois grandes grupos ${ }^{27}$ :

(i) Métodos qualitativos. Relacionam-se a estudos que não tentam quantificar seus resultados por meio de análises ou sumários estatísticos. Tipicamente envolvem consultas a documentos históricos e oficiais, entrevistas e observações sem mensuração formal, principalmente realizando estudo de casos.

\footnotetext{
${ }^{26}$ Respectivamente, Professores Dame Hazel Genn, Martin Partington e Sally Wheeler. Vide (Genn, Partington, and Wheeler 2006)..

${ }^{27}$ Vide (Marczyk, DeMatteo, and Festinger 2005) . Para explicações gerais sobre a aplicação de métodos quantitativos ao direito, uma boa obra de referência é (Georgakopoulos 2005).
} 
(ii) Métodos quantitativos. Envolvem estudos que utilizam análises estatísticas para fazer inferências e obter suas conclusões. Buscam, basicamente, medir diversas facetas de determinados fenômenos de modo a identificar suas dimensões. As características essenciais dessas metodologias incluem a mensuração formal e sistemática, e o uso de técnicas econométricas.

Cada conjunto de metodologias tem sua utilização, e a combinação de metodologias não é necessariamente desaprovada. Thomas Kuhn (1961: 161), inclusive, afirmava que "grandes quantidades de trabalho qualitativo têm sido pré-requisito para quantificações proveitosas"28.

No caso específico da análise pretendida, metodologias qualitativas serão úteis para isolar e estudar com detalhes eventos e casos individuais, iluminar evoluções históricas, descobrir motivações e interesses, e refletir sobre relações de causalidade. Nos casos em que a complexidade é grande, em que quantificar relacionamentos é difícil, ou em que é interessante perceber no detalhe estratégias e ações, análises qualitativas são indicadas. Em particular, identificar os papéis desempenhados ao longo de processos de integração por determinados atores como grupos burocráticos, agentes privados, coalizões de governo, e autoridades estrangeiras, qual sua relevância, e como as reformas se construíram.

Metodologias quantitativas, por sua vez, são úteis para localizar os efeitos agregados e tendências gerais relacionadas a processos de integração financeira sobre uma economia. Localizam-se variáveis explicativas de interesse, postulam-se relacionamentos entre elas, formulam-se hipóteses sobre o efeito dos processos de integração sobre tais variáveis, desenvolvem-se modelos e instrumentos de mensuração, coletam-se os dados necessários, rodam-se os modelos e avaliam-se os resultados. Em especial, seria interessante explorar a relação entre acordos de liberalização financeira e quatro elementos: aumento de fluxos de serviços financeiros, crescimento econômico,

\footnotetext{
${ }^{28}$ No original em inglês: "large amounts of qualitative work have usually been prerequisite to fruitful quantification in the physical sciences". Vide (Kuhn 1961, 161).
} 
desenvolvimento e aprofundamento de mercados financeiros, ocorrência de crises financeiras.

Vê-se, portanto, que as metodologias podem ser em muitos aspectos complementares. Por essas razões, entendeu-se ser possível organizar a pesquisa segundo $\mathrm{o}$ indicado na tabela abaixo:

\begin{tabular}{|l||}
\hline \multicolumn{2}{|c|}{ ESTRUTURA DA TESE DE DOUTORADO } \\
\hline 1. Introdução \\
PARTE 1 - Estrutura Jurídica da Globalização \\
Financeira \\
2. Estados e a formação de sistemas financeiros \\
nacionais \\
3. Estados e a internacionalização das finanças \\
PARTE 2 - Efeitos da Globalização Financeira \\
4. Análise comparativa: Processos de integração, seus \\
determinantes e seus efeitos \\
5. Considerações finais. \\
\hline
\end{tabular}

\section{I.2.3. PARTe 1 - Estrutura JURídica da GlobalizaÇão FinanCEIrA}

A primeira (1) parte consistirá de dois capítulos discutindo os arranjos jurídicoinstitucionais que geraram a globalização financeira. A metodologia a ser utilizada será primordialmente qualitativa. Realizar-se-ão reconstruções institucionais comparadas, discutindo a evolução de certos arranjos de governança do sistema financeiro. Dois conjuntos de análises de casos serão realizadas: (1) uma sobre a formação comparada de Sistemas Financeiros Nacionais, e (2) outra sobre processos comparados de integração financeira.

\section{I.2.3.1. Capítulo 1: Governos e a formação de Sistemas Financeiros Nacionais.}

O Capítulo 1 retomará a proposição $\mathrm{P} 1$ e buscará compreender como o relacionamento entre Estados e instituições financeiras levou à formação de Sistemas Financeiros Nacionais. Para esse fim, serão comparados os casos da formação dos SFNs de cinco países - Inglaterra, França, Alemanha, Estados Unidos e Brasil. O estudo de tais casos permitirá que sejam identificados os instrumentos jurídicos que foram 
desenvolvidos para permitir intervenções no setor financeiro, e as motivações dos governos nacionais para executá-las. O objetivo deste capítulo será analisar a moldura jurídica que capacitou governos nacionais a controlar, e, muitas vezes, bloquear transações financeiras transfronteiriças.

\section{I.2.3.2. Capítulo 2: Governos e a internacionalização das finanças.}

O Capítulo 2 retoma a proposição P2 e busca compreender por que e como o relacionamento entre governos e instituições financeiras se modificou a ponto de tornar mais poroso, e, em alguns casos, mesmo dissolver os Sistemas Financeiros Nacionais e permitir a ocorrência da globalização financeira. Para esse fim, serão comparados cinco processos de integração financeira: a liberalização financeira unilateral brasileira; a criação da Área Financeira Européia; os Acordos da Basiléia; o regime da IOSCO de cooperação entre reguladores; e a assinatura do Acordo sobre Serviços Financeiros da OMC. O estudo de tais casos permitirá que sejam identificados os instrumentos jurídicos que foram desenvolvidos para permitir que bancos e investidores estrangeiros adquirissem ativos financeiros em mercados domésticos, e que instituições financeiras e investidores locais passassem a operar em mercados estrangeiros. O objetivo desse capítulo será analisar a moldura jurídica utilizada por governos nacionais para a permitir e incentivar tais transações transfronteiriças.

\section{I.2.3. PARTE 2 - DETERMinANTES E FEITOS Da GLOBALIZAÇÃo FinANCEIRA.}

A segunda (2) parte consistirá de um capítulo discutindo determinantes e efeitos da globalização financeira. Aplicar-se-ão métodos econométricos sobre uma grande base de dados reunida e criada exclusivamente para esta pesquisa.

\section{I.2.3.1. Capítulo 3: Análise comparativa: Processos de integração e seus efeitos.}

O Capítulo 3 retomará a proposição $\mathrm{P} 3$, e, partindo das discussões dos capítulos anteriores sobre instrumentos jurídicos e seu uso por governos nacionais, buscará compreender determinantes e efeitos de processos de integração financeira. Para esse fim, foi construída uma grande base de dados que tabula acordos comerciais, acordos de harmonização, acordos de mútuo reconhecimento e acordos de cooperação. Tal base de dados será utilizada em análises econométricas sobre os determinantes desses processos e suas conseqüências. 
PARTE I

ESTRUTURA JURÍDICA DA GLOBALIZAÇÃO FINANCEIRA 


\section{Capítulo 1}

\section{GOVERNOS E A FORMAÇÃO DE SISTEMAS FINANCEIROS NACIONAIS}

\section{I.1. INTRODUÇ̃̃o}

Este capítulo analisará a gênese de um arranjo jurídico-institucional que precedeu a globalização financeira do final do século $\mathrm{XX}$, dominou, durante quase um século, a organização das relações entre Estado e instituições financeiras e foi reproduzido em diversos países: o Sistema Financeiro Nacional. Foi esse arranjo nacional que a globalização desintegrou.

Tal forma de organização do setor financeiro, centralizada e baseada na circunscrição das atividades de instituições financeiras ao território nacional, surgiu do interesse privilegiado que governos nutriram, desde cedo, na atividade financeira. A Thomas Jefferson é imputada, por exemplo a idéia de que bancos são mais perigosos que exércitos $^{29}$. De fato, controlar um banco dá acesso perene a uma fonte de crédito para financiar as atividades governamentais. Isso per se implica adquirir um instrumento de política inestimável, tanto em tempo de guerra, como de paz: a capacidade de levantar recursos sem aumentar impostos. Todavia, não explica por que seria necessário controlar todos os bancos operando em território nacional. Tampouco justifica a necessidade de se impor controles sobre a operação de instituições financeiras no mercado doméstico, e de

\footnotetext{
${ }^{29}$ No original em inglês, a citação é "I sincerely believe that banking establishments are more dangerous than standing armies.". Vide (Jefferson 1816).
} 
bancos nacionais no exterior. São esses questionamentos que o capítulo pretende responder.

Propõe-se aqui que Sistemas Financeiros Nacionais são conseqüências da atividade dos Estados na consolidação de usa dominância sobre mercados nacionais, e no apoio ao desenvolvimento industrial. Tal proposição advirá do estudo comparado dos processos de gênese da regulação financeira nacional e da formação do sistema financeiro nacional dos seguintes países: Grã-Bretanha, França, Alemanha, Estados Unidos e Brasil. Em cada desses casos, o objeto da análise será a relação entre Estado e instituições financeiras. Para entendê-la, será narrado um sucinto histórico jurídico-institucional dos processos, serão descritos os instrumentos jurídicos criados e utilizados, os objetivos buscados pelos governos, e os resultados atingidos em termos de reorganização do setor financeiro. Deseja-se compreender motivações, meios e conseqüências desses processos.

A estrutura do capítulo é a que se segue. O item (I.2) dividirá a formação dos Sistemas Financeiros Nacionais em três fases: (i) nascimento da atividade financeira, (ii) organização de sistemas financeiros que promovem a industrialização, e (iii) imposição de controles de fluxos de capitais e nacionalização dos mercados. Essa periodicização será aplicada ao estudo dos casos inglês, francês, alemão e norte-americano. Considera-se que tais casos são exemplares por sua diversidade e representatividade. Completar-se-á a exposição com a descrição do caso brasileiro, que ilustra processos de industrialização tardia copulada com projetos de neo-nacionalismo econômico.

O item (I.3) isolará os elementos jurídico-institucionais dos processos, descrevendo a moldura jurídica que permeou a construção dos arranjos nacionais. Iniciará por classificar e discutir seis tipos de instrumentos jurídicos desenvolvidos pelos governos nacionais, que podem ser depreendidos dos processos analisados no item anterior. São eles: restrições estruturais, restrições operacionais, esquemas emergenciais e de salvamento, restrições a transações internacionais, obrigações e padrões de compartilhamento de infraestrutura, e incentivos territoriais ao desenvolvimento. $\mathrm{Na}$ seqüência, discutirá razões para que governos utilizem os instrumentos identificados. 


\section{I.2. RECONSTRUCÃ̃O INSTITUCIONAL: CASOS SOBRE A FORMAC̃̃̃ DE SISTEMAS FINANCEIROS NACIONAIS.}

\section{I.2.1. Pressupostos da ANÁlise.}

Para estudar os casos a serem expostos neste e no próximo capítulos, partir-se-á de um pressuposto bastante importante. Interesses das instituições financeiras e dos governos podem convergir e divergir dependendo dos sistemas de representação política, por um lado, e dos sistemas de regulação que os governos podem impor sobre os bancos, por outro. Em outras palavras, confluência ou dissonância entre os interesses dos governos nacionais e dos bancos dependem do acesso que os bancos têm aos governos, e das relações de dependência e comando que os governo têm relativo aos bancos, respectivamente. Assim, a idéia de que governos são influenciados pelas instituições financeiras é germana da idéia de que têm de ser estabelecidas formas de controle sobre a atividade financeira.

Pode-se pensar em ambos os processos como sendo grandes barganhas entre governos nacionais e instituições financeiras, em que um governo, que presta contas a sua comunidade política, tenta maximizar a parcela da renda nacional que controla ${ }^{30}$. Para isso, deve definir o nível e forma de intervenção do Estado no setor financeiro. Negociase, portanto, se uma maior ou menor presença de estrangeiros em cada um dos segmentos do mercado nacional deve ser autorizada, se os agentes privados devem ter mais ou menos liberdade de ação, se intermediários financeiros controlados pelo governo devem ter mais ou menos participação. A tabela abaixo indica os tradeoffs referidos: regulação/liberalização, protecionismo/abertura financeira, e nacionalização/privatização.

\footnotetext{
${ }^{30}$ Para uma formalização do modelo analítico, vide (Mirandola 2006).
} 


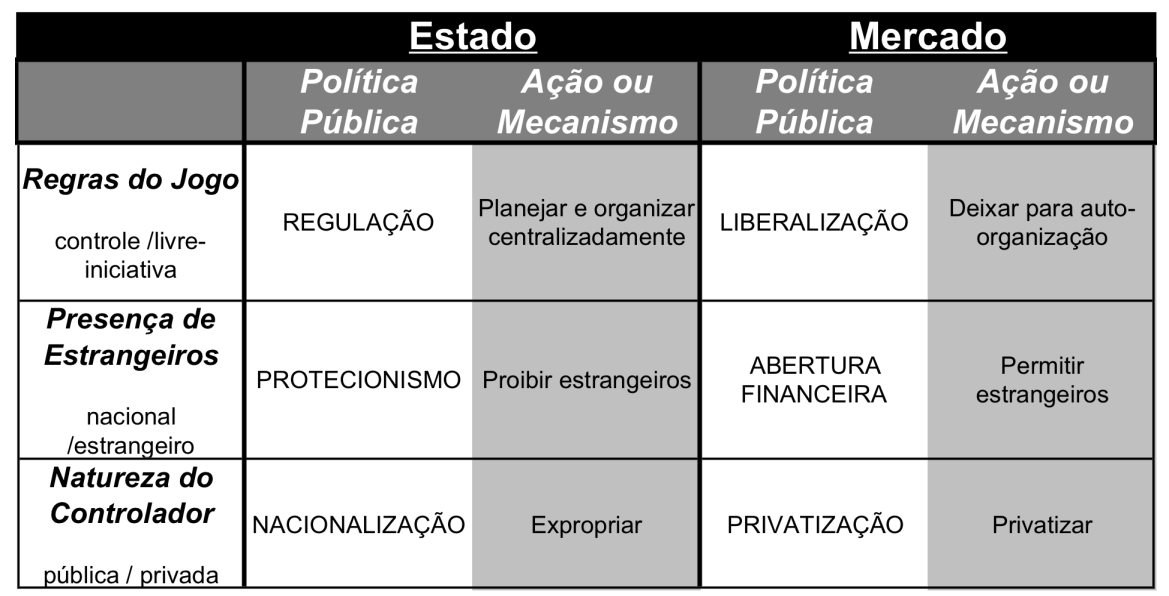

É importante notar que governos e atores privados maximizam funções-objetivo diferentes. Enquanto pode-se supor, por exemplo, que os intermediários financeiros privados estão preocupados em maximizar seus lucros, deve-se assumir que os governos maximizam uma função muito mais complexa, dando importância a variáveis como estabilidade do sistema financeiro (ou seja, as preferências dos reguladores), rendas, mordomias e desvios de recursos (as preferências dos burocratas), crescimento econômico (as preferências agregadas do eleitorado), questões horizontais ou difusas como maior proteção do consumidor (preferências da coalizão dominante), proteção e facilidades (preferências de grupos de pressão específicos), etc..

É possível saber, no entanto, quando mudanças e reformas levarão a um arranjo específico? As combinações institucionais dificilmente são as mesmas e suas histórias resultam de diversas opções políticas, idiossincrasias nacionais, e política. Destarte, descobrir qual o exato equilíbrio entre abertura financeira e proteção, liberalização e regulação, nacionalização e privatização, pode ser um trabalho bastante difícil. Entender quais são as barreiras a serem retiradas, quais segmentos de mercado devem ser liberalizados, em quais a competição e a presença estrangeira devem ser restringidas, é complicado. O efeito do direito sobre a organização econômica e sobre o bem-estar das populações nacionais é difícil de ser medido. Daí que compreender como governos nacionais escolhem sua proximidade e abertura em relação as setores financeiros nacional e internacional é tarefa controversa.

O presente capítulo (I) e o subseqüente Capítulo (II) buscarão, portanto, apresentar histórias jurídico-institucionais dos casos a serem estudados. Respectivamente, 
neste capítulo (I) ver-se-ão casos sobre formação de sistemas financeiros nacionais. No capítulo (II), serão explorados processos de integração financeira. Objeto por excelência dos estudos de caso serão os relacionamentos entre governos nacionais e instituições financeiras, suas características e os arranjos de governança criados.

\section{I.2.2. O NASCIMENTO DA ATIVIDADE FINANCEIRA: OS PRIMEIROS BANCOS E A CONSOLIDAÇÃO DA DOMINÂNCIA DOS GOVERNOS SOBRE MERCADOS NACIONAIS.}

Diz-se que os primeiros bancos nasceram provavelmente no oriente: na Babilônia templos eram utilizados como local em que se podiam depositar bens e valores em busca de segurança ${ }^{31}$. No ocidente, a primeira notícia que se tem de uma organização que centralizava depósitos e os protegia, coordenava pagamentos e fazia compensações, data de dois séculos antes de Cristo, é grega e estava localizada na cidade de Delos no Mediterrâneo. No entanto, a atividade bancária na forma hoje realizada remonta a tempos mais recentes, nos séculos XII e XIII, e relaciona-se às feiras de Champagne e ao renascimento comercial.

$\mathrm{Na}$ origem, aliás, já era internacionalizada. Mercadores de toda a Europa percorriam grandes distâncias para se encontrar e comerciar numa região parte do que viria a ser a França. Traziam consigo moedas, ouro e outros bens para troca, e, para evitar salteadores e facilitar seu deslocamento e suas negociações, deixavam tais valores sob a custódia de profissionais que se responsabilizavam pela sua segurança. O fornecimento de tais serviços era dominado por lombardos (italianos), mas judeus, cahorsianos e cavaleiros templários também tinham sua parcela no negócio ${ }^{32}$. Recibos e certificados de depósito eram fornecidos aos consumidores, e tais instrumentos, por representarem os valores depositados, serviam de moeda de troca nas feiras. As obrigações eram reguladas por normas costumeiras, as controvérsias eram dirimidas em tribunais corporativos, e executadas por armadas particulares.

Chamados campsores, os banqueiros passaram a prosperar e institucionalizar suas casas bancárias na Europa. A gama de produtos também aumentou. À modalidade de depósito foram, aos poucos, adicionados serviços de câmbio e compensação. $\mathrm{O}$ câmbio era importante tendo em vista a multiplicidade de regiões da Europa de que vinham os

${ }^{31}$ Vide (Braithwaite and Drahos 2000, 90).

${ }^{32}$ Vide (Baldwin 1968, 96). 
comerciantes. Quanto à compensação, ela surgiu quando os campsores passaram a fazer acordos pelos quais aceitavam certificados de depósito emitidos por outras casas bancárias. Era, portanto, um sistema de compensação privada. Isso obrigou ao surgimento de um outro sistema de compensações, desta vez interbancário: encontrandose nas feiras de Champagne, Lyon, Anvers e Gênova, os campsores ajustavam freqüentemente suas contas 33 .

O aumento do volume de depósitos, a redução da variedade de moedas disponíveis, e o aprendizado de técnicas de contabilidade permitiram que um outro tipo de serviço começasse a ser oferecido: os serviços de crédito e empréstimos. Na verdade, tais serviços surgiram como uma solução a um problema prático que os campsores enfrentavam: o excessivo risco de se manter entesourada num mesmo local uma grande quantidade de recursos. Emprestá-los reduzia o montante in specie sob custódia do banqueiro. No entanto, logo tal negócio mostrou-se bastante lucrativo. Já no século XIV a prática se difundiu e os banqueiros tornaram-se também financistas. Os volumes à disposição das grandes casas bancárias tornou-se tão grande que reis, rainhas e grandes mercadores europeus passaram a desenvolver estreitas relações com campsores. Os principais, as famílias italianas como Bardi, Peruzzi e Medici começaram a gozar de prestígio político junto às Coroas européias. Financiavam guerras, gastos das monarquias, a exploração de novos negócios, empreendimentos comerciais e aventuras mercantis como as grandes navegações. As finanças também internacionalizaram-se.

Comércio e serviços bancários andam de mãos dadas. Comerciantes geram recursos e os depositam junto a bancos; banqueiros reúnem tais recursos e emprestam a tomadores que desejam iniciar novas atividades comerciais; clientes descontam instrumentos de crédito e realizam compensações via sistema bancário; reis e rainhas retiram somas vultosas junto a grandes banqueiros para financiar a construção de armadas e exércitos para guerrear, conquistar, conseguir recursos, e pagar suas dívidas. Financistas como os das Casas de Fugger e de Rotschild adquiriram a proteção de governos nacionais justamente devido à dependência das coroas dos novos Estados nacionais em relação aos mercados financeiros. A Antuérpia no século XVI, Amsterdã a

\footnotetext{
${ }^{33}$ Vide (Holdsworth and Potton 1937, 128-129).
} 
partir do século XVII, e Londres no século XIX tornaram-se os centros financeiros dominantes ${ }^{34}$.

A relação entre as casas bancárias privadas e os governos nacionais desde essa época é bastante estreita e, às vezes, tensa, como se pode imaginar. Governos têm interesse de defender os interesses dos bancos de que são próximos, e bancos dependem de governos nacionais para que sejam estabelecidas políticas que os favoreçam; governos desejam ser independentes dos bancos, e bancos desejam que governos não prejudiquem suas atividades. As casas bancárias começaram a crescer de duas formas. A primeira era o financiamento do comércio internacional; a segunda eram os empréstimos para governos. O crescente papel dos financistas privados passou a preocupar os governos nacionais. Maior controle sobre as atividades domésticas dos bancos passou a ser exercido. Os Sistemas Financeiros Nacionais foram criados com o intuito de solucionar tais divergências e tensões. Diversas formas institucionais foram testadas.

O primeiro banco de depósitos controlado por um governo foi estabelecido em Gênova em $1407^{35}$. Outra experiência importante foi a criação do Banco de Amsterdam, em 1609: teve como um de seus objetivos impor uma moeda padronizada que pudesse circular por todas as Províncias Unidas, unificando o sistema financeiro. A experiência mais marcante do período, no entanto, foi a criação do Banco da Inglaterra em 1694. Para financiar a guerra com a França, a Coroa inglesa decidiu ver-se independente dos banqueiros privados. Garantiu, então, a uma companhia sediada em Londres o monopólio dos serviços financeiros e proibiu a incorporação de qualquer outra sociedade cujo objeto fosse emitir notas bancárias. O Banco da Inglaterra era um caso sui generis de banco privado controlado pelo governo ${ }^{36}$.

\section{I.2.3. O INÍCIO DOS SISTEMAS FINANCEIROS NACIONAIS ORGANIZADOS PELO ESTADO: BANCOS QUE PROMOVEM A INDUSTRIALIZAÇÃO.}

O sistema bancário contemporâneo data, no entanto, do século XIX impulsionado pela revolução industrial. Nasceu centrado no papel dos Estados nacionais na organização dos Sistemas Financeiros Nacionais. No início, a atuação dos governos teve como

\footnotetext{
${ }^{34}$ Vide (Germain 1997, 34-44).

${ }^{35}$ Vide (Kindleberger 1984, 47).

${ }^{36}$ Vide (Cameron and Neal 2003, 277).
} 
principal característica a criação de um sistema que visaria a oferecer crédito para a industrialização. Quatro experiências principais representam o movimento no período: a da Inglaterra, centrada numa versão reformada do Banco da Inglaterra; a da França, que incentivou a criação de outros bancos para diminuir a própria dependência dos Rothschild; a da Alemanha, que incentivou a criação de bancos "universais" ou "mistos"; e a dos Estados Unidos da América, por alguns chamados de "bancos livres"

\section{I.2.3.1. O exemplo inglês.}

No caso inglês, sempre foi mais fácil a abertura de empresas bancarias. O número de bancos até 1750 era aproximadamente uma dúzia; entre 100 e 150 por volta de 1775 ; acima de $800 \mathrm{em} 1810^{38}$. Uma lei adotada em 1844 reduziu o monopólio bancário do Banco da Inglaterra à emissão de notas, permitindo a abertura de outras companhias bancárias. Com isso, diversas companhias bancárias começaram a ser criadas para receber depósitos e emprestar para novos negócios, geralmente a curto prazo. Sua quantidade cresceu bastante por volta de 1870, quando começou um movimento de fusões e consolidações que reduziu o número de companhias para $40 \mathrm{em} \mathrm{1914.} \mathrm{Cinco}$ delas, Barclays, Lloyds, Midland, National Provincial e Westminster, que eram sediadas em Londres mas tinham operações nacionais, passaram a controlar mais de dois terços de todos os ativos bancários totais na Grã-Bretanha.

Além das companhias bancárias, os grandes financistas privados de Londres continuaram trabalhando com financiamento do comércio internacional, mercado de câmbio, e organizando algumas emissões de títulos estrangeiros: N. M. Rothschild \& Sons, Baring Brothers, e J.S.Morgan \& Co. (esse último, fundado por um financista norte-americano) operavam a partir do mercado de Londres, especializados em investimentos estrangeiros. Outrossim, uma diversidade de pequenas instituições especializadas como sociedades hipotecárias e caixas de poupança passaram a prosperar.

O Banco da Inglaterra, em seu turno, passou a responder por e monopolizar as quatro funções que, na atualidade, pertencem ao que se convencionou chamar de funções de bancos centrais: (i) emprestador do governo; (ii) regulador da moeda; (iii) banqueiro

\footnotetext{
${ }^{37}$ Vide (Cameron and Neal 2003, 277-285).

${ }^{38}$ Vide (Davies 1994, 286).
} 
dos bancos; (iv) emprestador de última instância ${ }^{39}$. É preciso que se tenha em mente que não existia no início do século XVIII uma teoria da moeda e de bancos centrais.

\section{I.2.3.2. O exemplo francês.}

O caso francês teve uma evolução parecida, apesar de mais tardia. O Banco da França era uma instituição estatal criada em 1800 por Napoleão para impulsionar os negócios governamentais. A tal banco foram garantidos desde cedo diversos privilégios e o monopólio da emissão de notas. Além disso, proibiu-se a criação de companhias bancárias privadas que pudessem tomar depósitos do público.

Ainda assim, subsistiu a haute banque ou haute finance parisienne, que era formada pelos financistas privados especializados em comércio internacional, câmbio e investimentos estrangeiros. Mas, na França, tais grandes banqueiros exerciam a função de financiar a expansão das ferrovias e da navegação, investimentos de grande monta organizados pelo governo francês.

A partir de 1851, visando a diminuir sua própria dependência da haute banque, Napoleão III decidiu permitir que mais instituições financeiras privadas fossem criadas. Iniciou-se assim a carreira de uma outra família de financistas, os irmãos Émile e Isaac Pereire, antigos colaboradores dos Rothschild que passaram a competidores. Em 1852 fundaram a Société Générale de Crédit Mobilier, um banco de investimentos especializado em financiar estradas de ferro, e Société Générale de Crédit Foncier, especializado em hipotecas. Além disso, os novos bancos passaram a apoiar a expansão francesa ultramar, financiando investimentos franceses no estrangeiro. Ainda assim, era o Banco da França o principal regulador do mercado, adotando políticas bastante conservadoras e restritivas em relação à presença de agentes privados.

\section{I.2.3.3. O exemplo alemão.}

O caso alemão é ainda mais tardio, até por causa das condições políticas. Durante toda a primeira metade do século XIX inexistia um Estado alemão propriamente dito porque a unificação ainda não havia ocorrido. Prússia, Baviera e Saxônia tinham, cada

\footnotetext{
${ }^{39}$ Vide (Morgan 1965, 1).
} 
uma, bancos que monopolizavam a emissão de notas, que eram regulados estritamente por seus governos, e eram especializados em financiamento governamental. Diferentemente dos casos inglês e francês, numerosos bancos privados existiam, principalmente nos importantes centros comerciais como Hamburgo, Frankfurt, Colônia, Dusseldorf, e Berlim. Tais bancos eram focados no financiamento do comércio local e internacional, e na administração de fortunas privadas.

No entanto, esses bancos dependiam da autorização do governo dos diversos principados e reinos alemães para serem incorporados - o que ocorria muito raramente. Somente em 1869 a Confederação Norte-Germânica, a Prússia alargada pela Guerra Austro-Prussiana, passou a permitir a livre-criação de bancos à exemplo da França e Inglaterra. O modelo bancário surgido, no entanto, era o dos Kreditbanken, banco "universal" ou "misto", que operava crédito de curto e longo prazos (investimentos).

Com o final da Guerra Franco-Prussiana e unificação alemã, mais de uma centena de Kreditbanken foram criados, inclusive os "D-Banken": Deutsche Bank, DiskontoGesellschaft, Dresdner e Darmstädter. No entanto, a crise de 1873 detonou um processo de concentração bancária semelhante ao inglês, e 12 grandes bancos com rede de afiliadas espalhadas por todo o território alemão passaram a dominar o mercado. Dos modelos europeus, os bancos alemães foram os que mais apoiaram a expansão industrial do país. Diz-se que os bancos alemães acompanhavam as empresas "do berço ao túmulo" ${ }^{40}$; o fato é que tais bancos investiram na expansão do comércio internacional alemão. No início do século $\mathrm{XX}$, os bancos alemães eram os mais fortes do mundo. Ademais, somente em 1875 é que foi criado, o Reichsbank, banco estatal com o monopólio de emissão de notas e funções de Banco Central.

\section{I.2.3.4. O exemplo norte-americano.}

A última experiência bancária exemplar é a norte-americana. Na verdade, pode-se considerar que ela se caracteriza pela inexistência de um modelo: durante todo o século XIX qualquer pessoa poderia criar um banco e não existiu, até 1913, uma autoridade bancária federal. Esse fato reflete fortemente as discussões entre Hamiltonianos (partidários de maior papel papel governo federal) e Jeffersonianos (partidários de maior

\footnotetext{
${ }^{40}$ Vide (Cameron and Neal 2003, 280).
} 
autonomia dos estados federados). Daí que o surgimento de um banco federal que exercesse as funções de Banco Central era bastante controversa. Em dois governos de inspiração Hamiltoniana leis autorizando a criação de um Banco dos Estados Unidos foram baixadas. O primeiro banco nasceu em 1791 e morreu em 1811 com a nãorenovação de sua carta-patente pelo Congresso; o, 80\% de seu capital era controlado por entes privados, e a maior parte de seus recursos vinha de atividades comerciais. Mas, ainda assim, assumiu funções típicas de banco central, como ser o principal depositário e agente fiscal do Tesouro, gerenciar a reserva nacional de ouro e prata, e fazer empréstimos temporários aos bancos estaduais com problemas de liquidez. $\mathrm{O}$ segundo nasceu em 1816 e morreu em 1836, assassinado igualmente pelos democratas Jeffersonianos. Teve, porém, mais poderes que seu predecessor.

A legislação bancária norte-americana até a década de 1860 era estadual, com cada estado realizando experimentos bancários. Alguns permitiam a abertura de bancos sem necessidade de autorização ("banco livre"); outros tinham bancos públicos; uns poucos tentaram proscrever a atividade bancária de forma definitiva. Os bancos norteamericanos não somente ofereciam crédito, mas, também, moeda - notas que, teoricamente, eram lastreadas em depósitos em ouro e prata. E, como eram abertos em áreas remotas do país, muitas vezes era impossível trocar as notas pelo lastro.

Durante a Guerra Civil, no entanto, o Congresso criou o Sistema Bancário Nacional por meio do National Currency Act de 1863 e do National Banking Act de 1864. Estabeleceu-se o Comptroller of the Currency, órgão federal que emitia cartaspatente permitindo a operação de bancos nacionais. A tais bancos era permitido que emitissem notas bancárias e as pusessem em circulação por seu valor integral, sendo lastreadas em títulos do governo. Além disso, obrigava-se que os bancos mantivessem reservas correspondentes às notas emitidas e depósitos recebidos. Por causa da supervisão, das políticas mais restritivas de crédito, e das limitações em fazer investimentos, o modelo do banco nacional era menos atrativo do que o do banco estadual. Por isso, o Congresso determinou em 1865 que sobre as notas emitidas pelos estaduais incidisse um imposto de $10 \%$. A intenção era fazer com que tais bancos fossem postos fora do negócio e só sobrassem bancos nacionais. No entanto, bancos estaduais 
sobreviveram devido a uma inovação financeira: os depósitos à vista em conta corrente. Isso permitiu que os bancos funcionassem sem precisar emitir notas bancárias.

O nível de regulação, tanto no âmbito federal, como no estadual, cresceu entre 1864 e meados de 1900, mas pânicos financeiros e corridas bancárias continuaram a acontecer $^{41}$. Em 1913 foi editado o Federal Reserve Act que criou uma segunda autoridade monetária nacional, a federação de doze Bancos do Sistema da Reserva Federal, que era dirigida pela Conselho da Reserva Federal. Fazer parte do sistema era obrigatório para os bancos nacionais e opcional para os estaduais. Os bancos comerciais que se juntassem ao sistema compravam ações do Banco de seu distrito e podiam participar da eleição de seis dos nove diretores da Reserva. Esta tinha poderes para fazer o redesconto de papéis de seus membros, emprestar recursos, manter reservas de seus bancos membros, e realizar operações com títulos públicos no mercado aberto. Por fim, tanto à Reserva Federal como ao Comptroller of the Currency foi dada a autoridade de supervisionar e examinar os bancos membros ${ }^{42}$.

\section{I.2.4. NACIONALIZAÇÃO DOS SISTEMAS BANCÁRIOS: A CRISE DOS ANOS 1920/1930, AS GUERRAS. E A IMPOSIÇÃO DE CONTROLES NA ATIVIDADE BANCÁRIA E NOS FLUXOS DE CAPITAIS.}

Uma das principais características do período de grande liberdade vigente no final do século XIX e início do século XX era a possibilidade de bancos instalarem-se nos diversos países sem maiores óbices. A regra geral era de liberdade do fluxo de capitais. Observava-se ao redor do mundo que os bancos mais importantes da Europa e dos Estados Unidos abriam filiais suas no estrangeiro, acompanhando os fluxos comerciais. Isso podia acontecer porque a entrada em países estrangeiros era simples, assim como a operação e a saída.

A Grande Depressão dos anos 1930 provocou mudanças sérias nesse panorama. A situação era catastrófica ${ }^{43}$. Para retirar os Sistemas Financeiros Nacionais da bancarrota, os governos nacionais passaram a implantar estritos controles e regulamentos nos

\footnotetext{
${ }^{41}$ Por exemplo, o Sistema Bancário Nacional passou por uma grande crise em 1907. Na ausência da autoridade central, foram os banqueiros privados obrigados a intervir para salvar os bancos: J.P.Morgan e James Stillwell agiram como reguladores e evitaram o desastre financeiro. Vide (Germain 1997, 50).

${ }^{42}$ Vide (Spong 2000)

${ }^{43}$ Por exemplo, se em 1921 havia nos Estados Unidos aproximadamente 30.000 bancos em funcionamento, em 1933 esse número caiu para menos da metade, totalizando 14.500 bancos em operação (Spong 2000).
} 
diversos setores financeiros, de modo a reduzir as pressões desagregadoras. Com isso, a atuação dos intermediários financeiros tornou-se cada vez mais sujeita a regras específicas dos países.

Esse movimento de aumento da intervenção dos governos no sistema financeiro foi seguido de uma onda de nacionalismo. Fluxos internacionais de capital passaram a sofrer restrições, e a operação de bancos estrangeiros em território nacional começou a ser vista com certas reservas. Mesmo no pós-II Guerra Mundial as nações mais liberais entendiam que excessiva movimentação de capitais em nível internacional poderia gerar especulação demasiada. Harry Dexter White e John Maynard Keynes, representantes respectivamente dos Estudos Unidos e da Grã Bretanha nas negociações de Bretton Woods, concluíram que uma ordem financeira liberal prejudicaria o papel do Estado no domínio doméstico ${ }^{44}$. O livre-comércio era ingrediente da receita para a paz mundial; a livre circulação de capitais, não.

Os dois fatores levaram ao surgimento simultâneo nos diversos países de uma regulação financeira protecionista, que privilegiava a estabilidade e a segurança sobre a competição e o risco ${ }^{45}$. Segmentos de mercado foram cercados e separados, e fornecedores específicos foram designados para explorá-los. O que Moran (1984: 5) chamou regulação "esotérica" - porque as regras eram tiradas do debate aberto, formal, democrático, e decididas em privado, de modo informal, e técnico - passou a imperar no planos nacionais. Novamente, expõem-se abaixo quatro casos paradigmáticos: Inglaterra, França, Alemanha e Estados Unidos.

\section{I.2.4.1. A peculiar informalidade inglesa.}

As mudanças na regulação inglesa tiveram como característica principal a informalidade: o sistema de supervisão bancária estabelecido a partir dos anos 1930 não era baseado em nenhuma lei, mas, sim, na auto-regulação. Nesse sentido, destoava sumamente do que acontecia em outros países. As "regras" informais não deixavam de ter, todavia, os mesmos efeitos encontrados nas outras jurisdições. Quando, por exemplo, o Banco Lazard necessitou em julho de 1931 de socorro, o Banco da Inglaterra não

\footnotetext{
${ }^{44}$ Vide (Meerschwam 1991, 25).

${ }^{45}$ Vide (Coleman 1996, 3).
} 
titubeou e evitou o pânico na City londrina. No entanto, como compensação, solicitou que seu Escritório de Redesconto fosse informado das posições de capital do Lazard. Caso contrário, não ofereceria acesso às suas linhas de redesconto. Isso foi repetido com outros bancos e o Redesconto tornou-se o braço supervisor de facto do Banco da Inglaterra $^{46}$.

O poder normativo do Banco da Inglaterra surgiu de maneira bastante simples: quando de sua nacionalização em 1946, a lei lhe deu poderes para emitir "orientações" para bancos em diversas questões. Todavia, tal mecanismo era considerado deveras formal e as "orientações” foram substituídas por polidas cartas dirigidas às instituições apropriadas, indicando as preocupações do regulador e como dever-se-ia proceder para sanar os problemas encontrados. As cartas não tinham força de lei, mas estavam escoradas na autoridade moral do Banco. A filosofia era de confiança nos administradores; mais burocracia poderia desencorajar diversidade e inovação ${ }^{47}$.

Quatro elementos estruturais caracterizavam a organização dos mercados financeiros ingleses até a década de 1970: (a) o mercado bancário era segmentado e havia controles quando às taxas de juros, principalmente no que se refere ao financiamento de casas, depósitos e poupança, banco postal, e compensação; (b) os mercados em geral eram auto-regulados, o que implicava, muitas vezes, o estabelecimento de cartéis, seja por segmento de mercado, seja por meio das associações de serviços específicos; (c) a auto-regulação era a tônica no mercado de valores mobiliários, com a Bolsa de Valores de Londres instituindo as principais regras para evitar fraudes, procedimentos para operação e compensação, e criação de novos mercados; (d) a City londrina era a sede dos principais Euromercados (moedas) e realizava a maior parte das transações de Eurobonds na Europa.

\section{I.2.4.2. O dirigismo francês.}

A França sofreu especialmente durante a II Guerra Mundial, mas sua reconstrução também foi uma das mais rápidas. $\mathrm{O}$ dirigismo estatal foi uma das características mais salientes nos mercados financeiros franceses. Trata-se, no entanto, de um caso de

\footnotetext{
${ }^{46}$ Vide (Coleman 1996, 176).

${ }^{47}$ Vide (Coleman 1996, 177).
} 
intervenção direta: em 1945 os quatro maiores bancos comerciais - O Crédit Lyonnais, a Société Générale, a Banque Nationale pour le Commerce et l'Industrie, e o Comptoir National d'Escompte de Paris - foram nacionalizados e reestruturados, sendo que os dois últimos foram fundidos na Banque Nationale de Paris ${ }^{48}$.

Os representantes do Estado nos conselhos diretores dos bancos utilizavam sua influência para implantar metas e objetivos de política pública. Além disso, a nacionalização era usada como uma oportunidade para promover e participar de mais fusões e parcerias, alavancando a posição francesa na economia mundial. Políticas de modernização da indústria também se tornaram possível tendo em vista que o governo podia condicionar operações financeiras a mudanças em políticas estratégicas de empresas. Uma outra função bastante importante era aquela relativa ao financiamento de infraestrutura social e habitação.

Os mercados financeiros eram bastante segmentados como na Inglaterra ${ }^{49}$. Bancos comerciais operavam sob diferentes regras em relação aos bancos de atacado, caixas econômicas, e cooperativas financeiras. Corretores de valores mobiliários monopolizavam as transações no mercado acionário. O crédito agrícola era subsidiado, havia bancos populares que distribuíam crédito para governos locais, e os mercados hipotecários eram insulados, não sendo sensíveis às variações das taxas de juros. Outrossim, os pequenos bancos podiam emprestar dinheiro diretamente do banco central, o que os fazia menos dispostos a concorrer pela captação de depósitos. Todas essas distorções faziam com que os mercados de capitais não fossem bem desenvolvidos, e que as empresas dependessem do crédito bancário para financiamentos de longo prazo.

\section{I.2.4.3. Os influentes bancos alemães.}

No caso alemão, o aspecto mais importante do sistema financeiro vigente no pósII Guerra Mundial é a relevância dos bancos no desenvolvimento de indústrias e comércio. Bancos alemães destacam-se pela ênfase que dão ao papel de mobilizar fundos para investimento, privilegiando a poupança sobre o consumo. Nesse sentido, a influência do sistema financeiro sobre as corporações é grande: mais do que somente empréstimos,

\footnotetext{
${ }^{48}$ Vide (Coleman 1996, 42-43).

${ }^{49}$ Vide (Coleman 1996, 97-100).
} 
o financiar uma empresa muitas vezes tem o caráter de relacionamento de longo prazo ${ }^{50}$. Apoiando-se num impressionante trabalho de inteligência econômica, os bancos preferem traçar planos detalhados de longo prazo para seus investimentos, analisando setores e empresas com cuidado. Empresas dependem fortemente de capital de curto e longo prazo, e utilizam mais linhas de crédito bancário do que mercados de capitais. E, muitas vezes, as alianças entre bancos e indústria são seladas com bancos assumindo posições acionárias em alguns de seus clientes. Isso implicava muitas vezes um incentivo negativo para a mudança de controle das empresas. Essa era a versão de banco universal privilegiada pelos alemães.

Historicamente, a regulação financeira alemã buscou proteger o interesse geral da economia - e não defender os poupadores individuais. Isso quer dizer que depositantes eram protegidos por esquemas voluntários; instituições financeiras como cooperativas e caixas econômicas estabeleciam mecanismos de ajuda mútua para evitar que fossem à bancarrota - e não para permitir indenizações de poupadores. A auto-regulação sempre imperou. Reflexos disso também podiam ser sentidos nos mercados de capitais: as principais instituições reguladoras eram as bolsas de valores, sendo que a supervisão por autoridades estatais era mínima. Mesmo mercados de títulos recebiam pouca atenção estatal. Outrossim, o Bundesbank tinha uma preferência por determinar taxas de juros por meio de controle de reservas bancárias e não por operações no mercado aberto - o que implicava mais um motivo para reduzir o volume de operações em mercado.

Muitas vezes a regulação privada era manipulada por bancos locais para proteger bancos domésticos em relação às empresas financeiras estrangeiras. Todos esses fatores tinham efeitos sobre o grau de desenvolvimento dos mercados de capitais em relação ao PIB. Mesmo quando se tratava de negociar papéis de empresas alemãs, muitas vezes investidores preferiam se utilizar de euromarkets e eurobonds - ou seja, negócios com títulos e ações alemães eram preferencialmente realizados em mercados no exterior, geralmente Londres.

${ }^{50}$ Vide (Coleman 1996, 123-126). 


\section{I.2.4.4. A diversidade norte-americana.}

Diferente dos mercados financeiros europeus, o mercado norte-americano caracterizava-se por ser formado por milhares de instituições financeiras que detinham, mesmo as maiores, uma parcela de mercado bastante pequena. Trata-se de mercados diversos e complexos, em que subsistem milhares de intermediários financeiros especializados. Essas diversas instituições eram também intensamente reguladas A regulação financeira norte-americana é retratada por alguns comentaristas como um produto de crises $^{51}$ : as mudanças nas regras e nas instituições regulatórias para os mercados financeiros parece sempre vir na esteira de cataclismos. No caso da regulação que perdurou da década de 1930 até o final de 1970, a crise à época foi diagnosticada como sendo o resultado de dois fatores: (i) a "excessiva e destrutiva competição" entre os bancos; e (ii) empréstimos excessivamente arriscados concedidos a especuladores da bolsa $^{52}$.

A reação a esse diagnóstico veio na forma das chamadas leis bancárias de 1933 (o Glass-Steagall Act) e 1935. Em primeiro lugar, estabeleceram-se tetos para a juros de remuneração de depósitos (o que se convencionou chamar, após, de Regulação $Q$ ). Tal regulamento surgiu com base no diagnóstico de que os banqueiros, desejando atrair mais fundos para poderem emprestar, estariam a pagar juros excessivos, o que tornaria a atividade bancária inviável.

Em segundo lugar, as disposições de "banco livre" teriam criado excessiva competição e excessiva abundância de "bancos fracos". Passou-se a exigir que, para receber uma carta-patente, um candidato a banqueiro teria de demonstrar "necessidade pública" de criação de um banco naquela região, que seria lucrativa sua operação, e que não seriam causados danos indevidos às instituições existentes. Em terceiro lugar, os critérios para determinar a solidez financeira dos futuros proprietários do banco foram tornados mais rígidos. Em quarto lugar, as atividades de banco de varejo e banco de investimento foram separadas, sendo que a mesma pessoa jurídica deixou de poder exercer ambas ao mesmo tempo.

Além dessas medidas estruturais, foi criada uma seguradora para proteger os poupadores - a FDIC - Federal Depoist Insurance Corporation. Ela tinha competência

\footnotetext{
${ }^{51}$ Vide (Spong 2000, 5).

${ }^{52}$ Vide (Burton and Lombra 2005, 231)
} 
para fazer supervisão bancária e garantir depósitos até um certo valor. A separação de atividades financeiras gerou uma segmentação de mercados mais branda do que a vigente na França e na Alemanha tendo em vista que os tetos de taxas de juros eram menos freqüentes e mais flexíveis, quando existentes. Seguiram-se à FDIC seguradoras para as cooperativas de crédito chamadas FSLIC - Federal Savings and Loans Insurance Corporation e a NCUSIF - National Credit Union Share Insurance Fund.

Para regular os investimentos, foi criada em 1934 a SEC - Securities and Exchange Commission, o regulador para mercados de capitais. A SEC tinha como função principal a proteção do investidor individual, obrigando as empresas cujas ações fossem negociadas em bolsa a disponibilizarem diversos tipos de informações financeiras e corporativas aos acionistas. A SEC também tinha competência sobre a regulação de fundos e outras atividades de mercados secundários.

Toda essa diversidade regulatória institucionalizada implicou uma grande pulverização de produtos. Além disso, a grande variedade de reguladores provocou uma segregação entre os diversos agentes financeiros - a necessidade de se manter uma correspondência entre regulador e regulado forçou essa clivagem. Ademais, na regulação financeira norte-americana existia mais uma forma de segmentação dos agentes financeiros: a segmentação territorial. Introduzida pelo McFadden Act de 1927, proibia que bancos nacionais estabelecessem filiais em outros estados norte-americanos que não aqueles em que tinham primeiramente se estabelecido. Além disso, obrigava os bancos nacionais a seguirem as regras que os estados em que estavam instalados impunham para a atividade bancária.

\section{I.2.5. INDUSTRIALIZAÇÃo TARDIA E NACIONALISMO ECONÔMICO: A FORMAÇÃo do Sistema FinANCEIRo NaCiOnal BraSiLEIRo.}

O histórico da formação do sistema financeiro brasileiro ${ }^{53}$ mescla aspectos dos dois processos descritos acima. No Brasil, a intervenção governamental para implantar uma política de industrialização veio de mãos dadas com o nacionalismo econômico.

\footnotetext{
${ }^{53}$ Para uma revisão do histórico da formação econômica do Brasil, vide entre outros: (Almeida 1992; Antônio Barros de Castro and Souza 1985; Antônio Barros de Castro and Souza 2004; Giambiagi and Villela 2005; Lorenzo-Fernández 1980; Martins 1961; Moura 2007; Neuhaus 1980; Peláez 1987; Prado Júnior 1963; Ellis 1969; Sodré 1967; Studart 1995).
} 


\section{I.2.5.1. Primeira fase: Bancos a serviço da corte.}

O surgimento de casas bancárias no Brasil foi tardio e excepcional. Até 1808, ano em que foi criado o primeiro Banco do Brasil, não havia no país nenhum banco. Com a chegada de D. João VI, foi necessário abrir uma instituição para guardar os fundos reais, organizar as finanças do império, e financiar a transferência da corte. Sua duração, no entanto, foi efêmera: abriu as portas em 1809 e encerrou suas atividades em 1829. Além de ser envolvido em desastrosos financiamentos a exportações, o banco teve seus cofres esvaziados pela independência - D. João VI teria levado boa parte do lastro metálico de volta a Portugal após 1822. Somente na década de 1830 outras experiências foram intentadas: em 1831 foi estabelecida a primeira caixa econômica, em 1833 a Lei no 59, de 08.10.1833 criou o segundo Banco do Brasil, o primeiro banco comercial privado nasceu (Banco do Ceará). A primeira faliu na seqüência, e o segundo não conseguir ter seu capital integralizado, e o terceiro fechou as portas em 1839.

Vingou, todavia, o Banco Comercial do Rio de Janeiro, e seu sucesso incentivou a o surgimento de outros bancos na Bahia, Maranhão e Pernambuco. Durante a década de 1840 o negócio bancário teve relativo sucesso, e em 1851 o Decreto $\mathrm{n}^{\mathrm{o}} 801$, de 02.08.1851 criou o terceiro Banco do Brasil, este sob controle privado. A Lei $n^{\circ} 683$, de 05.07.1853 determinou a fusão entre o BB e o Banco Comercial do Rio de Janeiro, o que criou o primeiro banco de cobertura nacional; essa operação deu origem ao quarto Banco do Brasil. Permitiu-se a criação de novos bancos, inclusive estrangeiros: entraram em funcionamento os primeiros bancos estrangeiros: o London \& Brazilian Bank e o The Brazilian and Portuguese Bank, cujas operações concentravam-se no Rio de Janeiro.

\section{I.2.5.2. Segunda fase: As primeiras instituições regulatórias.}

Os anos que se seguiram foram turbulentos. A libertação de 800.000 escravos em 1888 destruiu da noite para o dia importantes ativos de fazendeiros; alimentos tornaramse escassos, colheitas foram perdidas, e a inflação subiu. A República foi proclamada em 1889, e, no ano seguinte, foi editado o primeiro pacote de reorganização do sistema financeiro brasileiro. O objetivo era impulsionar a industrialização, e a política escolhida foi incentivar o surgimento de um mercado de capitais pujante. Em 17 de janeiro de 1890 decretou-se lei bancária autorizando emissões bancárias lastradas em títulos da dívida pública. Para canalizar os recursos provindos dessas emissões, foram criados três bancos 
regionais, na Bahia, em São Paulo e no Rio Grande do Sul, e um Banco dos Estados Unidos do Brasil (renomeado mais tarde Banco da República do Brasil), no Rio de Janeiro. Além disso, abriu-se o país para investimentos internacionais, permitindo-se a instalação de empresas de infraestrutura. Empréstimos no exterior foram feitos, o que aumentou a dívida externa. A emissão desenfreada de moeda gerou inflação, especulação e uma bolha no mercado de ações, que, ao estoxurar, levou a uma grande recessão, falências, fraudes, e a quebra da bolsa de valores.

As três décadas seguintes foram gastas na reorganização do sistema bancário. No processo, cinco medidas são notáveis. Em primeiro lugar, o Decreto $\mathrm{n}^{\mathrm{o}} 1.455$, de 30.12.1905 determinou a fusão do Banco do Brasil de 1853 com o Banco da República do Brasil, criando o quinto Banco do Brasil. Em segundo, a Lei no 4.182, de 15.11.20 (alterada pela Lei $n^{o} 4.230$, de 31.12.20, e pelo Decreto $n^{0} 19.525$, de 24.12.30) criou a Carteira de Redesconto, e o Decreto n ${ }^{\circ}$ 21.499, de 09.06.32 (alterado pelo Decreto-lei $\mathrm{n}^{\mathrm{o}}$ 6.419, de 13.04.44) estabeleceu a Carteira de Mobilização e Fiscalização Bancária. Na prática, ambas as medidas outorgaram ao Banco do Brasil poderes de autoridade monetária, respectivamente, emprestador de última instância e gerente da massa monetária.

Em terceiro, criou-se a Inspetoria Geral dos Bancos, prevista no artigo $5^{\circ}$ do Decreto $\mathrm{n}^{\mathrm{o}} 4.182$, de 13.11.20, e no artigo $2^{\circ}$ da Lei $\mathrm{n}^{\mathrm{o}} 4.230$, de 31.12.20. Alem disso, aprovou-se o regulamento para a fiscalização dos bancos e das casas bancárias (Decreto $n^{o} 14.728$, de 16.03.21). Em conseqüência, estabeleceu-se um sistema centralizado de registro e fiscalização dos bancos.

Em quarto, em 1921 criou-se a Câmara de Compensação de Cheques do Rio de Janeiro, sob a responsabilidade do Banco do Brasil, e em 1932 a Câmara de Compensação de São Paulo. Além disso, para massificar o crédito e ampliar a rede de atendimento bancário, em 1934 foram criadas as Caixas Econômicas Federais por meio do Decreto $\mathrm{n}^{\mathrm{o}}$ 24.427, de 19.06.34.

Foi, portanto, formada a espinha dorsal de um sistema financeiro nacional que se caracterizou por grande intervenção e participação direta do Estado. 


\section{II.2.5.3. Terceira fase: Bancos desenvolvimentistas.}

A terceira grande etapa do desenvolvimento do sistema financeiro brasileiro caracterizou-se pela criação de diversas instituições que visavam a dar suporte a um projeto de industrialização de cunho nacionalista. Tal projeto apoiava-se na criação de bancos de desenvolvimento públicos. Em 1942 nasceu o Banco de Crédito da Borracha para a fomentar novas atividades industriais no norte do país. Esse banco adotou posteriormente a denominação de Banco de Crédito da Amazônia, que foi mudada pela Lei $\mathrm{n}^{\mathrm{o}}$ 5.122, de 28.09.66 para Banco da Amazônia S.A. (BASA). Tratava-se de banco regional, que tinha como missão oferecer crêdito subsidiado para corrigir diferenças de desenvolvimento entre as diversas regiões do pais.

O segundo banco regional de característica desenvolvimentista, estabelecido em 1952 pela Lei $\mathrm{n}^{\circ}$ 1.649, de 19.07.52, foi o Banco do Nordeste do Brasil S.A. (BNB). A grande seca de 1951 precipitou sua criação: Horário Lafer, impressionado com a vulnerabilidade da economia nordestina às condições climáticas, sugeriu ao presidente Getúlio Vargas a criação do BNB com o objetivo de fomentar o desenvolvimento da região e torná-la mais independente da agricultura familiar.

Para a região centro-sul foi estabelecido o BNDE - Banco Nacional de Desenvolvimento Econômico, banco de fomento de característica mais agressiva e intervencionista. Criado pela Lei $\mathrm{n}^{\mathrm{o}} 1.628$, de 20.06.52, iniciou sob a forma de autarquia. Como principais missões estavam o financiamento de infraestrutura física e o incentivo a indústrias mais intensivas em capital. Do lado privado, em 1946, nasceu a primeira sociedade de crédito, financiamento e investimento (financeira). Todavia, tais sociedades não retiraram o viés intervencionista e centralizador do sistema financeiro nacional.

Do lado regulatório, a principal evolução foi a reorganização das funções do Banco do Brasil. A execução da política monetária estava dispersa dentro do banco por vários órgãos: a Carteira de Redesconto (CARED) executava as funções de emprestador de última instância; a política cambial era levada a cabo pela Carteira de Câmbio e Comércio Exterior (CACEX); operações de mercado para socorrer bancos com problemas de liquidez eram executadas pela Caixa de Mobilização Bancária (CAMOB). Além disso, a emissão de moeda era feita pela Caixa de Amortização do Ministério da Fazenda. O Decreto-Lei 7.293 de 02.02.1945 criou a Superintendência da Moeda e 
Crédito (SUMOC), presidida pelo Ministro da Fazenda. Seu Conselho era composto pelo Ministro, pelo presidente do Banco do Brasil, diretores da CARED, CACEX, CAMOB e Fiscalização Bancária, e por um Diretor Executivo.

\section{II.2.5.4. Quarta fase: O planejamento econômico da era militar e a intenção de se incentivarem instituições privadas.}

No início da década de 1960 o Sistema Financeiro Nacional Brasileiro era dominado completamente pelo governo. Tratava-se de um sistema de pouca profundidade e baixa penetração, tendo em vista o limitado escopo da captação de poupança. A maior parte dos bancos privados estava concentrada no centro-sul do pais, e os bancos de desenvolvimento regional eram responsáveis pela maior parcela do crédito ofertado à indústria.

O golpe militar de 1964 trouxe consigo um novo conceito de organização do sistema financeiro nacional ${ }^{54}$. A idéia principal era a de desenvolver os músculos do "braço privado" do sistema, que seria apoiado por pujantes mercados de capitais. Segundo os burocratas no comando das reformas de 1964/1967, o país estaria sofrendo um caso crônico de "finanças represadas" - por causa das distorções criadas pela pesada presença do Estado nos mercados financeiros, da inflação e do limite imposto pela Lei da Usura na cobrança de juros, a atividade bancária estaria submetida a um regime de retornos reais negativos, o que estaria inviabilizando maior dinamismo privado no setor bancário.

Logo em 1964 o governo aprovou um pacote de mudanças na estrutura do Sistema Financeiro Nacional. Criaram-se duas novas instituições (Lei $\mathrm{n}^{\circ} 4.595$, de 31.12.64): um Conselho Monetário Nacional (CMN), cujo papel seria regulatório e estruturante; e o Banco Central do Brasil, entidade autárquica substituta da SUMOC, que zelaria pela moeda e seria independente do Banco do Brasil. Pela primeira vez foi também editada legislação organizando o mercado de capitais brasileiro de forma centralizada (Lei $\mathrm{n}^{\mathrm{o}}$ 4.728, de 14.07.65). Ao Banco do Brasil foram reservados quatro papéis: agir como banco comercial, gerir o sistema de pagamentos do governo, financiar exportações e ofertar crédito rural, O BNDE deveria se concentrar no fomento de financiamento de longo prazo para a indústria e infraestrutura, e os bancos de

\footnotetext{
${ }^{54}$ Vide, além da bibliografia mencionada supra, (Hermann 2002; Luiz Fernando de Paula 1998)
} 
desenvolvimento regionais teriam atuação mais focada. Foi criado também o Sistema Financeiro da Habitação (SFH), financiado pela caderneta de poupança e centralizado num novo Banco Nacional da Habitação $(\mathrm{BNH})$ para oferecer crédito imobiliário e financiar a construção de casas (da Lei $n^{0}$ 4.380). Tal sistema foi fortalecido em 1970 pela criação da Caixa Econômica Federal, instituição financeira sob a forma de empresa pública (Decreto-lei no 66.303, de 06.03.70).

Uma grande mudança, todavia, estava prevista para a organização do setor bancário privado. As novas regras incentivavam a diversificação: criação de bancos comerciais para ofertar crédito de curto e médio prazo, e companhias de crédito, financiamento e investimento (financeiras) para financiar o crédito de consumo. Bancos de investimento privados foram regulados pela Resolução $\mathrm{n}^{\circ} 18$, de 18.02.66 do $\mathrm{CMN}$, sendo a eles reservado o papel de fornecer crédito de longo prazo e subscrever emissões de ações e dívida de companhias abertas. Foi regulamentado o papel das corretoras de valores: elas deveriam fomentar o crescimento dos mercados de capitais. Por último, outros tipos de intermediários financeiros foram autorizados. Em 1974, por exemplo, nasceram as sociedades de arrendamento mercantil.

A tabela abaixo mostra como evoluiu a estrutura do Sistema Financeiro Nacional Brasileiro.

\begin{tabular}{|c|c|c|c|c|c|c|c|c|c|c|c|c|c|}
\hline \multirow{3}{*}{ Ano } & \multicolumn{13}{|c|}{ Sistema Financeiro Nacional Brasileiro } \\
\hline & \multirow{2}{*}{$\begin{array}{c}\text { Total } \\
\text { Bancos }\end{array}$} & \multicolumn{3}{|c|}{ Bancos comerciais } & \multicolumn{3}{|c|}{ Bancos múltiplos } & \multicolumn{3}{|c|}{ Bancos de Investimento } & \multirow{2}{*}{ Financeiras } & \multirow{2}{*}{ Outras } & \multirow{2}{*}{ Total Geral } \\
\hline & & Total & Privados & Públicos & Total & Privado & Público & Privados & Federais & Regionais & & & \\
\hline 1964 & 362 & 362 & 312 & 50 & 0 & 0 & 0 & 0 & 2 & 1 & 134 & 26 & 525 \\
\hline 1976 & 122 & 122 & 79 & 43 & 0 & 0 & 0 & 29 & 3 & 12 & 145 & 1371 & 1682 \\
\hline 1988 & 111 & 111 & 77 & 34 & 0 & 0 & 0 & 56 & 2 & 13 & 107 & 1501 & 1790 \\
\hline
\end{tabular}

Foi também permitido às instituições privadas que captassem recursos no exterior. A Resolução $n^{\circ}$ 63, de 23.08.1967, do CMN, autorizou os bancos fazerem empréstimos no mercado financeiro internacional e trazerem os recursos ao mercado doméstico, o que provocou um grande afluxo de capitais. A maior exposição a mercados internacionais, todavia, não implicou abertura - eram apenas instituições brasileiras as responsáveis pelos empréstimos, sendo que apenas excepcionalmente agentes financeiros estrangeiros eram autorizados a operar em território nacional.

A estrutura financeira proposta pelas reformas de 1964/1967 tinha como característica a segmentação. A figura abaixo descreve o planejado: 


\begin{tabular}{|l|l|l|}
\hline \multicolumn{1}{|c|}{ Estrutura financeira proposta pelas reformas de 1964/1966 } \\
\hline Tipo de Poupança & \multicolumn{1}{|c|}{ Instituição } & Crédito rural (somente BB) \\
\hline Depósitos à vista & $\begin{array}{l}\text { Banco do Brasil } \\
\text { Bancos comerciais privados }\end{array}$ & Crédito ao consumidor \\
\hline Letras de câmbio & Companhias financeiras & Crédito de curto-prazo para empresas \\
\hline Cadernetas de poupança & Sistema Financeiro da Habitação & Capital de giro \\
\hline Hipotecas & Bancos de investimento & Crédito imobiliário \\
\hline Certificados de depósitos & Mercado acionário & Investimento de longo prazo \\
\hline Ações e debêntures & Mercado de títulos & Capitalização das empresas \\
\hline Títulos do governo & Déficits públicos \\
\hline
\end{tabular}

Fonte: adaptado de (Studart 1995, 119).

A teoria muitas vezes não se conforma à prática, todavia, e conseqüências colaterais surgiram dessa organização. Em primeiro lugar, teve início um processo de concentração bancária sem precedentes. Tamanho passou a ser importante, e os grandes conglomerados bancários que atuavam em todos os setores tinham grandes vantagens. Em segundo lugar uma nova bolha acionária foi criada e agravada por um conjunto de medidas de desoneração físcal, pela alta taxa de inflação, e pelo excesso de liquidez internacional. Em 1971 ocorreu um crash na Bolsa de Valores devido à especulação. Isso desorganizou novamente o mercado de capitais e afastou investidores. Para tentar conter os efeitos negativos da crise, em 1976 foram aprovadas duas novas leis. A primeira, a Lei das Sociedades Anônimas (Lei 6.404 de 15.12.76), estabelecia novos critérios de governança e obrigações de transparência para as companhias abertas. A segunda, a Lei da Comissão de Valores Mobiliários, (Lei $n^{0}$ 6.385, de 07.12.76), criava um novo regulador para o mercado de capitais, organizava o sistema de fiscalização e estipulava medidas para reprimir fraude a investidores.

O sistema financeiro que se seguiu tinha, no final das contas, as seguintes características. Em primeiro lugar, era inegável a importância do Estado em todos os níveis. Os maiores bancos comerciais pertenciam ao governo federal e aos governos estaduais, o crédito rural e imobiliário era estruturado por bancos estatais, a maior parcela do investimento de longo prazo saía dos cofres dos bancos de desenvolvimento nacionais 
e regionais. Em segundo lugar, havia uma grande tendência à concentração e conglomerização: as maiores instituições financeiras públicas e privadas atuavam em diversos segmentos de mercado de forma integrada, deixando poucos espaços para instituições menores. Em terceiro lugar, eram muito baixas a presença e participação de estrangeiros no mercado doméstico. Inclusive, captações internacionais, ou eram feitas diretamente pelo governo por meio de emissões soberanas de títulos em mercados estrangeiros, ou eram feitas por bancos brasileiros por meio de emissões comerciais autorizadas excepcionalmente pelos reguladores brasilerios. Em ambos os casos, após a internalização dos recursos, havia o repasse às instituições domésticas, que os distribuíam. Em quarto lugar, o mercado de capitais tinha papel secundário, sendo grande a dominância do setor bancário na atividade financeira. Em quinto lugar, foi atingido um grau superior de sofisticação e profundidade nos mercados financeiros.

\section{I.3. MOLDURA JURÍDICA DA FORMAČ̃̃o DE SISTEMAS FINANCEIROS NACIONAIS.}

A partir da comparação dos casos estudados acima, é possível identificar estruturas jurídicas e motivações da intervenção de governos nacionais no setor financeiro. Este item, portanto, tratará de analisar em (I.3.1) quais instrumentos foram criados, e em (I.3.2) a racionalidade da regulação financeira.

\section{I.3.1. COMO INTERVIR: INSTRUMENTOS REGULATÓRIOS DO MERCADO FINANCEIRO.}

Como visto acima, para impor sua dominância sobre os mercados domésticos e para utilizar o sistema financeiro nacionalizado em projetos de desenvolvimento industrial, governos nacionais tiveram que modificar sua relação com instituições financeiras domesticas. Para isso, foram criados instrumentos que implicaram a aquisição de poderes para regular os mais diversos aspectos da vida financeira. Seguindo a exposição, faz-se útil para os fins da tese apresentar organizadas algumas categorias exemplares de instrumentos utilizados para intervir em mercados financeiros que foram desenvolvidos nos últimos dois séculos.

Define-se, para tanto, seis grupos de medidas de política pública pelas quais governos substituem-se ao mercado: (i) restrições estruturais; (ii) restrições operacionais; (iii) esquemas emergenciais e de salvamento; (iv) restrições a operações internacionais; 
(v) obrigações de compartilhamento de infraestrutura; (vi) incentivos setoriais de desenvolvimento. Essas categorias foram organizadas tendo como base a bibliografia mencionada acima, os casos estudados, e diversos documentos de autoridades regulatórias internacionais ${ }^{55}$.

\section{I.3.1.1. Restrições estruturais.}

Restrições estruturais são aquelas referentes à maneira como os mercados financeiros são estruturados, ou seja: condições de entrada, saída, tipo de agente econômico, limitações quanto às atividades a serem desempenhadas, etc.. Na maior parte das vezes visam a quatro objetivos: (a) garantir níveis mínimos de solidez; (b) garantir níveis mínimos de qualificação de controladores e administradores; (c) reduzir ou controlar a competição de modo a evitar "excessos concorrenciais" e assegurar a rentabilidade das operações; (d) proteger ou isolar as empresas financeiras incumbentes (ou seja, as já presentes no mercado doméstico) de pressões competitivas. São exemplos de intervenção nos mercados as seguintes medidas:

- requisitos de entrada no mercado: requisitos de autorização, licenciamento ou permissão para entrada no mercado relacionados com capital mínimo, de justificativa econômica para a entrada de mais um fornecedor, números máximo ou mínimo de competidores (inclusive monopólios legais, duopólios, etc.), plano estratégico, etc.;

- requisitos de propriedade e administração: requisitos pessoais dos controladores e administradores como ausência de processos de inabilitação ou condenações administrativas ou criminais, exigências de especialização ou titulação, conflito de interesses, (no caso de pessoas físicas), nacionalidade (da pessoa física ou do capital), etc.;

\footnotetext{
${ }^{55}$ Além da bibliografia mencionada acima, vide (International Organization of Securities Commissions 1998b; Bank for International Settlements 2001b; Bank for International Settlements 2006; Bank of International Settlements 2006; Basel Committee on Banking Supervision 1983; Basel Committee on Banking Supervision 1992; Basle Committee on Banking Supervision (BCBS) 1988; Basle Committee on Banking Supervision (BCBS) 2006; International Monetary Fund 1999; International Organization of Securities Commissions 1998a; Bank and Fund 2005; Bank for International Settlements 1999; Bank for International Settlements 2001a).
} 
- requisitos de forma jurídica e organização societária: tipo de pessoa jurídica obrigatório, objeto social específico, vedações de participação recíproca, participação de grupo societário, natureza do controle, etc.;

- requisitos de fusão e incorporação de outros bancos: requisitos de participação ou poder de mercado máximos resultantes da operação, aprovação prévia de operações, proibições ou restrições de concentração vertical ou conglomeração, etc.

- requisitos de segregação de atividades: requisitos de separação entre atividades comerciais e de investimento, seguros e bancárias, especialização em determinados segmentos de mercado, etc.;

- requisitos de organização geográfica: restrições de abertura de filiais e agências, requisitos de cobertura geográfica mínima, segregação de mercados e praças, restrições para expansão geográfica, limitações para postos de atendimento, etc.

\section{I.3.1.2. Restrições operacionais.}

Restrições operacionais são aquelas referentes aos tipos de condutas e práticas permitidas aos agentes econômicos autorizados a operar no mercado. Visam, normalmente, a evitar riscos demasiados em operações e transações, assegurar práticas condizentes com a norma prudencial, reduzir exposição, tornar transparentes informações essenciais, coibir a competição desleal, e reprimir condutas anticoncorrenciais. São exemplos desse tipo de intervenção:

- requisitos de adequação mínima de capital e de reservas: obediência a critérios técnicos de adequação de capital e manutenção de reservas, regras de cálculo e contabilidade do capital e das reservas, adaptação do capital e das reservas ao nível de riscos da carteira e o tipo de operações em que o intermediário está envolvido, monitoramento, etc.;

- requisitos de participação em atividades especificas: restrições à participação em subscrições e distribuição de valores mobiliários, restrições de negociar em mercados secundários, de participar de emissões e outras operações; 
- requisitos de controle de riscos de gerenciamento: requisitos de conduta dos administradores, de sistemas de gerenciamento e supervisão, governança corporativa e regras específicas para conflitos de interesses;

- requisitos de processos de manejo de riscos: requisitos de sistemas de identificação, monitoramento, controle e mitigação de riscos materiais, revisão de procedimentos, rotinas de análise de riscos, rotinas de informação dos conselhos, etc.;

- requisitos de controle de risco de crédito: estratégias e sistemas de controle de risco de crédito, identificação de clientes e manutenção de banco de dados sobre situações e clientes arriscados, políticas comerciais e produtos adequados às estratégias, procedimentos adequados para aprovação de operações complexas, regras para evitar conflitos de interesse, transparência de informações de crédito, etc.;

- requisitos de controle de ativos problemáticos, provisões e reservas: requisitos de políticas e sistemas para controle de ativos problemático, cálculo de provisões e reservas, classificação de provisões para operações arriscadas, identificação e acompanhamento de deterioração de ativos e obrigações em atraso, rotinas, processos e estratégias de recuperação de ativos, sistemas de informação sobre o estado da carteira de empréstimos com atualização constante, leis, normas e regulamentos sobre classificação de ativos e lançamentos contábeis, etc.;

- requisitos de controle de exposição a grandes riscos e a outras empresas relacionadas: requisitos de sistemas de informação e controle de exposição a riscos anormais e conflitos de interesses; política de separação de ativos, identificação de transações proibidas, discriminação positiva, etc.;

- requisitos de controle de risco-país: requisitos de procedimentos e sistemas que identifiquem exposição excessiva, reservas inadequadas e avaliação de risco insuficiente em relação a ativos localizados em países de risco; procedimentos de supervisão e auditorias, etc.;

- requisitos de controle de riscos de mercado: requisitos de políticas e processos para identificação, avaliação, supervisão, monitoramento, controle de riscos de mercados, inclusive com cadeia de aprovação e responsabilização; requisitos de 
sistemas de informação atualizados com freqüência; requisitos de sistemas de coleta de dados de mercado, modelos de análise e políticas de avaliação; requisitos de estratégia para riscos; etc.;

- requisitos de controle de riscos de liquidez: requisitos de sistemas de informação e monitoramento ativos e passivos com atualização freqüente; requisitos de estratégias de gerenciamento de liquidez com supervisão dos conselhos da empresa compatíveis com estratégias de controle de risco; requisitos de sistemas de análise de passivos e ativos em moeda estrangeira compatíveis com a estratégia de gerenciamento de liquidez; etc.;

- requisitos de controle de riscos operacionais: requisitos de sistemas de informação e monitoramento de riscos operacionais; estratégias de identificação, isolamento, controle e gerenciamento de riscos operacionais, com planos de contingência; requisitos de sistemas de tecnologia e informação adequados ao volume de atividades da instituição; etc.;

- requisitos de limitação de taxa de juros: requisitos de sistemas de identificação, avaliação, monitoramento e controle de risco de taxas de juros nas carteiras de empréstimos; requisitos de políticas de taxas adequadas; etc.;

- requisitos de transparência e supervisão; requisitos de transparência de informações essenciais, controles e sistemas de supervisão adequados, adoção de sistemas contábeis e sistemas de auditoria, requisitos de comunicação com clientes, etc.;

- requisitos de controle de práticas anticompetitivas e desleais, etc.;

- requisitos de salvaguarda de ativos: requisitos de custódia, cálculo e identificação dos ativos dos clientes, requisitos de auditoria e requisitos relativos a falências, etc..

\section{I.3.1.3. Esquemas emergenciais e de salvamento.}

Regras e políticas públicas que estabelecem programas e mecanismos destinados a prover redes de proteção financeira para casos de emergências, crises e quebras. Tais mecanismos são destinados a controlar problemas de risco sistêmico, preservar 
poupadores, reduzir prejuízos de investidores, e evitar crises de grande escala. São exemplos desse tipo de intervenção:

- mecanismos emergenciais e redesconto: políticas públicas de "emprestador de última instância"; esquemas de identificação e monitoramento de problemas de liquidez em conjunto com linhas especiais de crédito direto; políticas públicas de contenção de problemas de liquidez; etc.;

- mecanismos de intervenção: regras e instrumentos de intervenção, saneamento e liquidação de instituições financeiras problemáticas com regras claras de responsabilização; etc.;

- mecanismos de salvamento de instituições financeiras: políticas públicas e esquemas de salvamento e recuperação de intermediários financeiros relevantes cuja falência provocaria repercussões sistêmicas como linhas de crédito privilegiado, reinvestimento, etc.;

- mecanismos de proteção sistêmica: políticas públicas, esquemas emergenciais e fundos de estabilização destinados a preservar a integridade do sistema financeiro nacional em caso de ameaças sistêmicas; etc.;

- mecanismos de proteção dos poupadores: fundos e esquemas de seguro para indenizar poupadores prejudicados com quebras de instituições financeiras, sejam elas bancárias, sejam elas não-bancárias, etc..

\section{I.3.1.4. Restrições a transações internacionais.}

Restrições a transações internacionais são aquelas referentes às operações transfronteiriças, ou seja, que envolvem duas ou mais jurisdições. São desenhadas tendo em vista três objetivos: (a) controlar o fluxo de capitais, seja para garantir liquidez internacional, seja para evitar a evasão; (b) evitar, mitigar ou remediar crises de liquidez e problemas cambiais; (c) combater crimes e ações criminosas de nível internacional como lavagem de dinheiro e terrorismo. São exemplos de intervenção nos mercados financeiros com tais objetivos as seguintes medidas:

- requisitos de cobertura: requisitos de cobertura de operações internacionais, operações de câmbio, operações casadas, etc.; 
- requisitos de entrada e saida de capitais: requisitos de limitações para entrada e saída de capitais, tributos, registro, proibições, controle de conta de capital, investimentos e desinvestimentos, remessas de capitais, abertura de contas no estrangeiro, controle de circulação de ativos de residentes no exterior, etc.;

- requisitos de transações permitidas: requisitos de limitações quanto aos tipos de operações internacionais realizadas; requisitos de limitações quanto à forma que as transações autorizadas são realizadas; requisitos de limitações quanto às pessoas que podem ser parte em transações internacionais; requisitos de limitações quanto às pessoas em nome das quais podem ser realizadas transações financeiras internacionais; etc.;

- requisitos de presença de presença comercial para realizar transações: transações internacionais só podem ser desenvolvidas por intermediários financeiros registrado junto às agências reguladoras, exigindo-se, para isso, presença comercial; etc.;

- requisitos de controle de movimentação de capital: requisitos de registro, propriedade, tributação, movimentação, transferência de propriedade, transações; requisitos de restrições sobre transações em paraísos fiscais, etc.;

- requisitos de transparência: requisitos de transparência de informações relevantes de transações internacionais; requisitos de bancos de dados de movimentações internacionais relevantes;

- requisitos de investimentos e participações em fundos estrangeiros e em operações internacionais: requisitos de restrições de constituição de fundos de investimento, saídas de capitais para aquisição de posições no exterior, tributação de ganhos decorrentes de investimentos internacionais, listas de exceção relativas a paraísos fiscais, etc.;

- requisitos de salvaguarda de balança de pagamento: requisitos de controles excepcionais de entradas e saídas de capitais em caso de crises de liquidez, desequilíbrios de balança de pagamentos e emergências financeiras nacionais;

- requisitos de investigação de origem dos capitais e combate à lavagem de dinheiro e ações de terrorismo: requisitos de sistemas de identificação, monitoramento e controle de práticas e clientes suspeitos; requisitos de 
transparência de informação de comportamentos, transações e clientes suspeitos; requisitos de políticas de "know your costumer"/"know your client"; requisitos de colaboração com investigações oficiais;

\section{I.3.'.5. Obrigações e padrões de compartilhamento de infraestrutura.}

Obrigações e políticas públicas que garantem a que infraestruturas financeiras compartilhadas essenciais como o sistema de pagamentos, o sistema de custódia e compensações de valores mobiliários, o sistema integrado de informações financeiras, e os cadastros de informações financeiras sejam compatíveis, seguros, estáveis, abrangentes, íntegros, e possam ser acessados pelas instituições financeiras em geral.

- acesso ao sistema de pagamentos: normas e regulações para garantir que as instituições financeiras concernidas tenham acesso ao sistema de pagamentos; além disso, deve-se garantir a segurança, continuidade, exatidão e confiabilidade do referido sistema;

- acesso a sistemas de custódia e liquidação: normas e regulações para garantir que as instituições financeiras concernidas tenham acesso ao sistema de custódia e compensações; além disso, deve-se garantir a segurança, continuidade, exatidão e confiabilidade do referido sistema;

- acesso a banco de dados e cadastros: normas e regulações devem garantir que bancos de dados financeiros sejam precisos, seguros e a informação neles contida permaneça sigilosa;

- acesso a sistemas de informação: normas e regulações devem garantir que os sistemas de informação sejam compatíveis, precisos e seguros.

\section{I.3.1.6. Incentivos setoriais de desenvolvimento.}

Políticas públicas de incentivo e fomento destinadas a desenvolver certos mercados financeiros específicos por meio de obrigações de alocação de recursos em carteira em produtos específicos, subsídios e linhas de crédito privilegiadas, etc.. Visam a tornar algumas atividades financeiras de relevância social mais atrativas, criando 
incentivos para que intermediários financeiros especializados em produtos específicos desenvolvam tais segmentos de mercado.

- subsídios setoriais ou horizontais: políticas públicas na forma de transferências diretas incondicionais, subsídios condicionais a desempenho, facilidades tributárias e outros incentivos fiscais destinados a desenvolver certa atividade financeira. Por exemplo: crédito para construção, microcrédito, crédito agrícola, etc.;

- linhas de crédito direto ou privilegiado: políticas públicas estabelecendo entre outras coisas linhas de crédito direto gerenciadas por intermediários financeiros determinados para incentivar atividades específicas;

- quotas mínimas e direcionamento de crédito: políticas públicas estabelecendo direcionamento de crédito obrigatório com especificação de porcentagem das carteira de crédito de intermediários financeiros específicos.

\section{I.3.2. POR QUE INTERVIR: REGULAÇÃO DE INSTITUIÇÕES FINANCEIRAS.}

Uma vez identificados os instrumentos pelos quais governos nacionais dos cinco países estudados intervieram na estrutura de seus mercados e na organização de suas instituições financeiras, pode-se analisar a racionalidade das intervenções. Para fazê-lo, proceder-se-á do seguinte modo. Em (I.3.2.1.) responder-se-á por que o interesse dos governos no setor financeiro. Começar-se-á por expor alguns elementos de microeconomia dos intermediários financeiros, de modo a identificar particularidades do setor que despertam o interesse dos governos. Na seqüência, o (I.3.2.2.) identificará três grupos de razões pelas quais os governos dos países estudados teriam reorganizado seus setores financeiros de forma tão intensiva. A primeira motivação identificada é consolidar a dominância governamental sobre o setor. A segunda é implantar uma política ativa de desenvolvimento para o setor financeiro de seus países. Era do interesse dos governos incentivar o aparecimento de um grupo de instituições financeiras de porte e alcance nacional que poderiam trabalhar sob a tutela governamental e servir de instrumento para a realização de políticas públicas. A terceira é implantar um conjunto de políticas regulatórias para corrigir distorções estruturais causadas pelas peculiaridades dos 
mercados financeiros. Tal regulação, devido às características e objetivos buscados, faria mais sentido se implantada em âmbito nacional.

\section{II.3.2.1. O que fazem intermediários financeiros: Elementos de microeconomia dos intermediários financeiros.}

Bancos de varejo, bancos de atacado, investidores institucionais, fundos mútuos, seguradoras, corretoras de valores imobiliários, e muitos outros partilham uma característica comum: são instituições que agem como intermediários financeiros. Até há alguns anos atrás, tais instituições eram vistas pela literatura econômica como subprodutos de custos de transação. Considerava-se que, num mundo perfeito em que não houvesse fricções nas transações econômicas intermediários financeiros, em geral, e bancos, em específico, não deveriam existir. A literatura neoclássica sobre crescimento e desenvolvimento econômico, por exemplo, considera que o setor financeiro teria um papel passivo de canalizar fundos de investimento (poupança) para seus usos mais $\operatorname{produtivos}^{56}$.

Nos últimos quinze anos, no entanto, uma importante linha de pesquisa tem sido desenvolvida no sentido de compreender o que se convencionou chamar de microeconomia dos intermediários financeiros. Os estudos dessa linha preocupam-se, principalmente, em encontrar um papel mais ativo para os intermediários financeiros. Em outras palavras, mais funções foram adicionadas ao rol de atividades exercidas pelas instituições financeiras ${ }^{57}$.

A primeira dessas funções é (i) fornecer acesso a um sistema de pagamento. Isso permite reduzir custos e aumentar a eficiência por meio da viabilização e manutenção de um sistema de pagamentos abrangente. Tal função envolve três atividades fundamentais. Primo, necessita-se gerenciar meios de pagamento, tarefa que envolve, principalmente, o câmbio e a compensação de instrumentos de pagamento. Secondo, é necessário gerenciar depósitos. Essa segunda tarefa é das mais complexas: no intento original, o dinheiro entregue pelo correntista no depósito deveria permanecer com a instituição. Isso demandaria (a) tecnologia que gerasse retornos de escala na guarda do dinheiro em

\footnotetext{
${ }^{56}$ Para uma recapitulação dessa literatura, vide (Mattoo, Rathindran, and A. Subramanian 2006).

${ }^{57}$ Vide (Freixas and Rochet 2008, 1-8)
} 
espécie; (b) incentivos para que o agente não perdesse ou investisse erradamente o dinheiro recebido; (c) regras de padronização e incentivos para que o metal precioso entregue fosse fungível de modo que não fosse necessário entregar ao sacador exatamente a mesmas moedas que ele entregou, mas, sim, uma quantia equivalente. Tertio, é necessário manter uma infraestrutura que permita a compensação de obrigações, a transferência contábil de recursos entre contas correntes, e a transferência física de fundos entre agentes econômicos.

A segunda dessas funções é (ii) a transformação de ativos. Refere-se a proporcionar liquidez de modo que agentes possam melhor escalonar no tempo o cumprimento de obrigações de acordo com sua disponibilidade de caixa. Freixas e Rochet $^{58}$ arrolam três tipos de transformações dos ativos executadas por intermediários financeiros. Primo, conveniência da denominação: é a escolha de uma unidade de conta para seus produtos que seja conveniente para seus clientes. Secondo, transformação de qualidade: ocorre quando um banco, emitindo dívida em nome próprio, consegue recursos cujas características de risco-retorno são melhores do que aquelas que conseguiria se vendesse sua carteira de empréstimos ou a securitizasse. São duas as possibilidades em que isso pode ocorrer: (a) quando existe uma assimetria de informação entre o banco (que detém a carteira) e o eventual comprador, e essa informação não é comunicável; (b) quando existirem indivisíveis que atrapalham os pequenos investidores e impedem que eles diversifiquem sua carteira. Tertio, transformação de maturidade: transformam-se os recursos recebidos do depositante ou poupador, que têm um vencimento ou maturidade em tempo indesejado, em recursos que, para o tomador, têm um vencimento ou maturidade em tempo desejado. Isso, obviamente, implica risco porque os recursos recebidos são ilíquidos a presente. No entanto, tais riscos podem ser precificados e operações de empréstimo interbancário, juntamente com derivativos financeiros (swaps e futuros, por exemplo) oferecem possibilidades de reduzir esses riscos.

A terceira (iii) função é o gerenciamento de riscos. Tem a ver com proporcionar melhor alocação de riscos, fornecer seguro e alocar perdas. Intermediários financeiros são capazes de executar melhor do que pessoas ordinárias três tipos de atividades. Primo,

\footnotetext{
${ }^{58}$ Vide (Freixas and Rochet 2008, 4-5).
} 
identificação, estimação e precificação de riscos: como são especializados (e mais eficientes, têm economias) em perceber os riscos existentes em relação aos mais diversos mercados e agentes, obter informação sobre tais riscos, e podem compará-los, os intermediários financeiros identificam, estimam e precificam com mais eficiência. Secondo, alocação de risco: a função de transformação de ativos tem implicações sobre o gerenciamento de riscos. Como têm acesso a diversos tipos de ativos com maturidades variadas, os intermediários financeiros podem alocar tais ativos eficientemente. Tertio, executar operações off the balance sheet: garantias, linhas de crédito e avais, por exemplo, não entram na contabilidade das empresas propriamente por não serem um ativo ou passivo genuíno, mas um fluxo de caixa aleatório. Nesse sentido, swaps, operações de hedge e subscrição de ações são de difícil avaliação e precificação. Intermediários têm acesso e desenvolvem tais operações.

A quarta (iv) função é o monitoramento e processamento de informação. Relações financeiras podem sofrer de problemas bastante sérios que prejudicam que transações sejam feitas: assimetria de informações e informação imperfeita. No primeiro caso, o emprestador sabe menos do que precisaria do tomador; no segundo caso, há dificuldades para conseguir a informação correta, ou racionalmente os agentes mantêm-se desinformados. Um dos motivos pode ser o de que não conseguem processar as informações recebidas. Intermediários financeiros investem em tecnologia informacional, o que lhes permite recolher, escolher, triar e armazenar informações. Bancos comerciais fazem isso por meio do desenvolvimento de relacionamentos duradouros com seus clientes (relational banking). Nesse caso, o monitoramento das práticas da empresa é menos custoso: a dependência de financiamentos e a possibilidade de que um banco the feche portas faz com que a empresa assuma a quantidade ideal de riscos no longo prazo. Do contrário, quando empresas lançam ações e títulos nos mercados de capitais, os bancos de investimento são responsáveis por coletar as informações necessárias pelos investidores para tomada de decisão.

Por último, alguns autores apresentam uma quinta (v) função de intermediários financeiros: eles seriam essenciais para o desenvolvimento econômico de um país. A partir de estudos na maior parte das vezes empíricos, estudiosos conseguem estabelecer uma correlação positiva entre a existência de um sistema financeiro bem 
desenvolvimento e o crescimento econômico de um país. Os trabalhos seminais nesse sentido, iniciadores da linha de pesquisa, foram publicados por King e Levine ${ }^{59}$. A discussão é longa e ainda não se chegou a um consenso. No entanto, a intuição teórica que tem sido utilizada para justificar o resultado empírico é que os mercados financeiros proporcionariam um processo de alocação de recursos mais consistente. E, tendo em vista que países em desenvolvimento por definição enfrentam problemas de escassez de capital, poderiam se beneficiar mais da criação de bons mercados financeiros. Os ganhos com o desenvolvimento financeiro viriam principalmente com o aumento de produtividade, incorporação de tecnologia, e formação de capital.

\section{I.3.2.2. Razões para intervenção governamental e formação de sistemas financeiros nacionais.}

I.3.2.2.1. Consolidar a dominância governamental sobre o setor financeiro: Nacionalismo financeiro.

Os governos nacionais nos casos estudados tenderam a adotar política protecionistas e discriminatórias na formação de seus sistemas financeiros nacionais. Há três motivos para isso. O primeiro é preservar uma base indígena de instituições em que se possa confiar e ter acesso direto. Em primeiro lugar, por causa do alinhamento de interesses: considerando-se que bancos domésticos, por mais internacionalizados que sejam, têm a maior parte de suas operações em território nacional, é de se ponderar que seria de seu interesse colaborar com o governo nacional quando necessário. Em segundo lugar está a questão do custo e risco. É mais barato e seguro emprestar de instituições nacionais e se financiar em moeda local - em última instância, o direito de senhoriagem gera ganhos, e o curso forçado da moeda garante que as instituições financeiras domésticas serão um público cativo e interessado em ser credor.

O segundo motivo é cultivar a subordinação e disciplina de seus bancos domésticos. Ao se colocar como fiador da proteção da indústria financeira nacional frente aos estrangeiros, o governo ganha poder de barganha, e, em conseqüência, um comportamento favorável de seus comandados. A ameaça subjacente de retirar favores

\footnotetext{
${ }^{59}$ Vide (King and Ross Levine 1993b; King and Ross Levine 1993a).
} 
estendidos à banca doméstica tem como efeito conseguir cooperação. Nesse delicado equilíbrio entre promover os interesses difusos e gerais do público e dos eleitores, poupadores e emprestadores (que gostariam de maior competição), e promover os interesses concentrados e específicos da indústria nacional (que deseja maior lucro e menor competição), um governo se põe em posição estratégica para obter a submissão dos bancos operando domesticamente.

O terceiro motivo é cultivar poder de barganha para poder se contrapor a outros governos estrangeiros. O jogo da proteção da indústria nacional é um exemplo clássico de dilema do prisioneiro aplicado às relações internacionais. Todos os governos, coletivamente, estariam num nível mais alto de bem estar se nenhum dentre eles protegesse sua indústria doméstica. Quando a proteção é disseminada, todos perdem. Livre competição entre nacionais e estrangeiros deveria, portanto, ser a regra. No entanto, os ganhos daquele que é o primeiro a burlar a regra podem ser muito grandes - assim como a tentação de fazê-lo. Ao impor um nível intermediário de proteção à sua indústria e aceitar que outros países também o façam de forma moderada, um governo aumenta sua margem de manobra perante os outros, reduzindo os ganhos da estratégia radical (não seguir a regra). Sendo assim, um acordo de requisitos mínimos de capital ${ }^{60}$, por exemplo, que seja pouco protecionista porque barra competidores mais agressivos, mas que seja respeitado multilateralmente e reduza a recompensa de estratégias protecionistas radicais, é potencialmente mais positivo do que um instável equilíbrio de ausência de regras, poderia descambar como a mesma probabilidade na livre-competição multilateral, ou no protecionismo generalizado. Para conseguir esse acordo, o governo deve ter poder barganha.

\section{I.3.2.2.2. Implantar uma política ativa de desenvolvimento do setor financeiro.}

A segunda característica similar no projeto regulatório dos governos nos casos narrados acima é o desejo de desenvolver o sistema financeiro nacional para transformálo num instrumento para realização de políticas públicas. Em conseqüência, não bastava regular seu funcionamento e relacionamento com clientes e emprestadores, protegendo as

\footnotetext{
${ }^{60}$ Vide o capítulo 2 para mais detalhes sobre a discussão do acordo sobre requisitos mínimos de capital da Basiléia.
} 
instituições domésticas da competição internacional; era também necessário promover o desenvolvimento do setor. Por meio do controle direto ou indireto dos diversos bancos em geral, governos nacionais poderiam consolidar sua dominância sobre mercados domésticos. Isso foi ainda mais patente nos países que utilizaram seus bancos para alavancar o desenvolvimento econômico, notadamente os casos da Alemanha, França, e, em grande medida, do Brasil. Um dos interesses, portanto, em passar a controlar a atividade financeira em território nacional era cultivar um aliado oferecesse um instrumento de intervenção que favorecesse a industrialização. Políticas específicas para desenvolver o setor financeiro foram necessárias tendo em vista as funções do setor financeiro apontadas acima.

Qual o ganho, no entanto, de se incentivar o desenvolvimento da atividade financeira? Em primeiro lugar, pode-se citar os ganhos microeconômicos. Seguindo Freixas e Rochet ${ }^{61}$, podem-se apontar quatro benefícios de uma política de apoio ao desenvolvimento de intermediários financeiros:

- Intermediários Financeiros reduzem custos de transação. Custos de transação são "os custos de se fazer funcionar um sistema econômico" ${ }^{\text {,62 }}$ intermediários financeiros reduzem o desperdício resultante de tais custos. Essa afirmação tem que ser entendida em seu real contexto, no entanto. Não se trata de uma redução ordinária de custos de transação, mas de uma derivada de economias de escala, de escopo, ou de qualquer outro tipo, originadas da existência de um agente especializado nessa atividade. Intermediários financeiros agregam valor porque são o menor caminho entre poupadores (investidores) e tomadores (empresários).

- Intermediários Financeiros são melhores seguradores por serem especializados em montar "pools"63 de riscos. A incerteza quanto ao futuro e às características de e outros agentes e transações, quando quantificável, pode ser precificável na forma de risco. Instituições financeiras são especialistas em agregar esses riscos de forma a diminuir e diluir no tempo e entre atores econômicos os prejuízos que puderem deles derivar.

\footnotetext{
${ }^{61}$ Vide (Freixas and Rochet 2008, 18-40).

${ }^{62}$ Trata-se de uma tradução livre de "costs of running the economic system". Vide (Arrow 1969).

${ }^{63}$ Não se conseguiu traduzir a expressão "pool” satisfatoriamente. Além disso, trata-se de termo técnico. Por isso, decidiu-se mantê-la.
} 
- Intermediários Financeiros facilitam o compartilhamento de informações. Dois agentes, um poupador, outro tomador, podem decidir não correr o risco de assinar um contrato de empréstimo porque não têm boas informações um do outro. $\mathrm{O}$ intermediário financeiro, por se relacionar com ambos freqüente e repetidamente, tem diversos mecanismos em seu poder para incentivar ambas as partes a divulgar suas informações privadas. Além disso, suas atividades gozam de sigilo legal, podendo tratar de informações críticas sem perder a confiança de seus clientes.

- Intermediários financeiros monitoram melhor o cumprimento de contratos e a divulgação de informações por parte de poupadores e tomadores. Monitoramento, na terminologia de Hellwig ${ }^{64}$, pode ter diversas significações. Pode ser triagem de projetos (ação ex ante), sendo utilizada no contexto de problemas de seleção adversa; pode ser prevenção de comportamentos oportunistas (ação ex post), sendo utilizada no contexto de problemas de risco moral; pode ser punição ou auditoria, sendo utilizada no contexto de inadimplementos, em que se quer evitar o descumprimento de contratos. Nessas três molduras, intermediários podem fazer mais eficientemente o trabalho de monitorar, seja porque se beneficiam de economias de escala e escopo advindas da especialização, seja por viabilizarem coalizões de pequenos poupadores que, caso contrário, não poderiam realizar sozinhos o trabalho de coordenação, seja porque é mais barato delegar a função de monitoramento às instituições do que realizar por si próprio.

Em segundo lugar, pode-se referir os ganhos macroeconômicos, lembrando-se do uso específico que o governo faz do sistema bancário. $\mathrm{O}$ sistema financeiro é instrumento de duas políticas macroeconômicas importantes: a política de juros e a política de câmbio. Tais políticas estão no coração das atividades que governos nacionais executam soberanamente. Quanto à política de juros, agindo como "banco dos bancos" e emprestador de última instância, o Banco Central tem a possibilidade de injetar liquidez no sistema e definir a taxa básica de juros com que todos trabalham. Além disso, existe uma série de preços que o governo define, por razões de política pública, mandatoriamente (tabelamento de juros, restrições de oferta, etc.).

${ }^{64}$ Vide (Hellwig 1991). 
Na prática, isso significa três coisas: (i) o governo faz uso estratégico do sistema financeiro para o manejo macroeconômico da economia; (ii) problemas redistributivos podem ser resolvidos via política de juros diferenciadas e subsídios; (iii) o governo, por conseqüência, cria grandes incentivos para comportamentos alinhados ou colusivos no setor. Quanto à política de câmbio, governos nacionais têm sérias preocupações quanto aos pagamentos internacionais que têm que fazer. A conta de capitais - ou seja, o item da contabilidade nacional referente ao movimento de capitais e moedas de um país - é variável importantíssima a ser considerada. Governos, portanto, impõem limitações ao livre movimento de capitais internacionais justamente porque desejam se manter líquidos e solventes em relação a suas próprias obrigações no estrangeiro. A incapacidade pública ou privada de adimplir dívidas externas é causa de graves crises financeiras. Ao impor restrições na exposição externa de agentes domésticos, limitar remessas de lucros ou repatriação de investimentos, ou controlar a entrada de agentes estrangeiros no país, governos nacionais tentam garantir sua solvência externa. Nessas situações, destarte, nacionalizar a regulação bancária implica reduzir o esforço do governo nacional na consecução dos objetivos de política macroeconômica almejados.

Em terceiro lugar está o ganho de política industrial. O setor financeiro é estratégico porque permeia a atividade econômica como um todo. Destarte, permite o direcionamento do crédito, que é crucial na atividade de indução - criar incentivos diferenciados para agentes privados, de forma a promover o crescimento de certos setores da economia, diferenciando-os dos outros setores.

\section{I.3.2.2.3. Implantar políticas regulatórias de âmbito nacional.}

Os cinco casos estudados scima e os elementos da economia bancária expostos nos itens anteriores indicam também que mercados financeiros têm uma série de peculiaridades estruturais que, se não controladas, podem levar a riscos sistêmicos, distorções alocativas, subutilização dos benefícios trazidos pela atividade financeira, e sub-investimento. Além disso, as distorções inseridas no sistema em vista das políticas protecionistas e de desenvolvimento do setor financeiro podem exacerbar os efeitos das peculiaridades estruturais da economia bancária. Nesse aspecto governos nacionais se 
vêm compungidos a implantar um regime regulatório centralizado de âmbito nacional, que possa racionalizar sua intervenção.

Quais distorções, no entanto, têm de ser enfrentadas? O primeiro aspecto genético peculiar a que se pode referir tem a ver com a propensão que os intermediários financeiros têm para correr riscos demasiados ${ }^{65}$. Por causa do instituto da responsabilidade limitada, e porque é difícil e caro calcular o risco de clientes, são grandes as probabilidades dos intermediários fazerem apostas arriscadas e tornarem-se, ou ilíquidos, ou insolventes. Isso deixa de ser um problema privado e passa a ser um problema do mercado de dois modos. Primo, existe a questão da corrida bancária ${ }^{66}$. Clientes não fazem depósitos em banco que não dá a segurança de que, quando solicitado, o dinheiro será devolvido. Se, por algum motivo, os clientes acreditarem que o banco se tornou insolvente, ele tornar-se-á insolvente - trata-se de uma profecia que se realiza sozinha. Secondo, existe o contágio: porque bancos operam em rede e podem multiplicar recursos, ou seja, produzir moeda, externalidades estão envolvidas no processo. Quando um banco enfrenta dificuldades, aumenta a probabilidade de que outros também as enfrente: um inadimplemento pode gerar reações em cadeia. Em vista de sua interconexão, é natural ver bancos operando num mesmo mercado como um sistema. Do mesmo modo, também é natural que governos nacionais queiram reservar um papel efetivo na demarcação dos limites dessas interconexões. A determinação, destarte, dos bancos que devem fazer parte do sistema nacional e dos bancos que não devem fazer passa pela definição de quais instituições serão socorridas pelos esquemas de salvamento de bancos mantido pelo governo nacional.

O segundo aspecto a ser referido relaciona-se às imperfeições e distorções no regime de competição. Governos nacionais têm interesse em nivelar o campo em que instituições financeiras competem. Todavia, só podem fazê-lo dentro do território em que têm jurisdição. Intermediários deixados ao léu podem não competir perfeitamente por uma série de razões. Em primeiro lugar, agentes financeiros operam tendo em vista a chamada assimetria de informações. Porque emprestadores têm alto custo para acessar as

\footnotetext{
${ }^{65}$ Existe uma grande literatura sobre regulação prudencial e riscos bancários. Para teoria, vide, por exemplo, (Dewatripont and Tirole 1994, 103-118; Jensen and Meckling 1976; Freixas and Rochet 2008, 191-287). Sobre práticas prudenciais e aspectos de política pública, vide (Bank and Fund 2005, 101-170).

${ }^{66}$ Vide, além da literatura mencionada anteriormente, (Diamond and Dybvig 1983; Allen and Gale 2000).
} 
informações creditícias dos tomadores, torna-se caro calcular o risco de emprestar. Daí que um agente especializado em recolher informações do mercado opera com grandes economias de escopo. Nesse sentido, a competição naturalmente torna-se restrita e, portanto, imperfeita. Após o relacionamento entre um banco e o cliente ter se estabelecido, o mecanismo chamado seleção adversa faz com que se reduzam os incentivos para que bancos roubem clientes uns dos outros: quando competem em preços, é grande a probabilidade dos bancos recrutarem clientes de grande risco sem saberem disso $^{67}$. Em segundo lugar, intermediários financeiros organizam-se em um mercado de rede - quanto maior for a participação de mercado de uma só instituição ou agente, mais o consumidor está disposto a pagar por seus serviços ${ }^{68}$. Bancos com agências em todos os estados, em que clientes podem fazer todo e qualquer tipo de transação movimentando facilmente (até pela Internet) seus recursos, são mais atrativos para o consumidor. Em terceiro lugar, os clientes têm, dificuldades para romper seu relacionamento com seu banco trocar de instituição. A esse elemento dá-se na literatura especializada o nome de switching $\operatorname{cost}^{69}$. O custo de se trocar um fornecedor por outro é muito alto, envolve burocracia e custos de oportunidade enormes. Em quarto lugar, estão as distorções causadas pela confiabilidade: um fator determinante na escolha de um banco é, justamente, sua solidez financeira ou reputação. Remuneração muito alta para depósitos, por exemplo, pode ser confundida pelo cliente com atos de desespero: trata-se de mais um caso de seleção adversa, desta vez do lado do poupador.

$\mathrm{O}$ terceiro aspecto peculiar que se quer mencionar se refere a uma função primordial dos bancos. Eles são fornecedores privilegiados de um bem público essencial: o sistema de pagamentos integrados ${ }^{70}$. Tal sistema é bastante delicado: além de ligar poupadores a tomadores, permite a circulação de riqueza, a compensação de obrigações, a redução de custos de transação, e a interligação de mercados. Reações em cadeia e a assimetria de informações entre os diversos atores do mercado o tornam bastante sensível e vulnerável. Além disso, considerando-se que se pode alegar com algum grau de certeza que o maior beneficiário individual de um sistema de pagamentos que seja o mais amplo

\footnotetext{
${ }^{67}$ Vide (Ausubel 1991; de Mello 2003; Ausubel 1999).

${ }^{68}$ Vide (Joskow and Noll 1999).

${ }^{69}$ Vide (Klemperer 1987a; Klemperer 1987b).

${ }^{70}$ Vide (Bank for International Settlements 2001a).
} 
possível é o governo nacional, tem-se mais um motivo para que a nacionalização do sistema financeiro tenha lugar.

Por essas razões, pode-se depreender dos estudos de casos descritos acima que governos nacionais tiveram grandes incentivos para fomentar a criação de sistemas financeiros nacionais, adotando o princípio de que deveriam reservar poderes incontrastáveis e efetivamente exercer regulação sobre toda a atividade financeira acontecendo em território nacional à exclusão de outros governos. Em primeiro lugar, há uma necessidade congênita de forte regulação prudencial e intervenção por parte dos governos nacionais. Estes desempenham o importante papel de assegurar a integridade e a estabilidade dos mercados financeiros, do sistema de pagamento e compensação. Além disso, em momentos de crise ou de falta de liquidez, as autoridades nacionais intervêm diretamente para evitar a desintegração do sistema financeiro nacional. Em segundo lugar, a competição perfeita enfrenta naturalmente obstáculos tendo em vista a estrutura do setor. Quanto a competição entre agentes é reduzida e a regulação e supervisão financeiras são deficientes, serviços financeiros são fornecidos e consumidos em menor quantidade do que idealmente seria necessário. Em terceiro lugar, para preservar seus instrumentos de política monetária e aumentar sua capacidade de intervenção, governos nacionais podem se sentir tentados a manipular as regras de funcionamento de seus sistemas financeiros. Por último, para garantir que o sistema de pagamentos seja o mais universal possível, abrangendo a maior parte da economia e dos agentes econômicos, e, ao mesmo tempo, reduzir a probabilidade de desagregação do sistema por causa de crises, e preservar poupadores e a poupança nacional governos agem para estabelecer políticas de incentivo à ampliação e garantia de solidez do sistema.

\section{I.3.2.2.4. Quadro analítico: Desenvolvimento de instrumentos de intervenção e razões}

para a intervenção.

Com base no histórico jurídico-institucional dos casos apresentados acima, no estudo dos instrumentos de intervenção desenvolvidos pelos governos nacionais para construir seus sistemas financeiros nacionais, e na análise das motivações para intervenção, é possível comparar a evolução de cada caso de formação de sistema 
financeiro nacional e classificá-los. Tem-se, por conseguinte, o seguinte quatro comparativo:

\begin{tabular}{|c|c|c|c|c|c|c|c|c|c|c|c|c|c|}
\hline & & \multicolumn{4}{|c|}{ Formaç̆o de SFNs (1800-1930) } & \multicolumn{4}{|c|}{ Nacionalizaçăo de SFNs (1930-1970) } & \multicolumn{4}{|c|}{ Brasil } \\
\hline & & Grä-Bretanha & Franca & Alemanha & $\begin{array}{l}\text { Estados } \\
\text { Unidos }\end{array}$ & Grã-Bretanha & Franca & Alemanha & $\begin{array}{l}\text { Estados } \\
\text { Unidos }\end{array}$ & Fase $I$ & Fase II & Fase III & Fase IV \\
\hline \multirow{3}{*}{$\begin{array}{l}\text { Restriçöes } \\
\text { estruturais }\end{array}$} & $\begin{array}{l}\text { Politicic protecionista e } \\
\text { daiscriminatória para } \\
\text { consolidar dominância }\end{array}$ & $\mathrm{x}$ & $\mathrm{x}$ & $\mathrm{x}$ & $x$ & $x$ & $x$ & $\mathrm{x}$ & $x$ & $x$ & $\mathrm{x}$ & $x$ & $x^{x}$ \\
\hline & $\begin{array}{l}\text { Poliftica ativa de } \\
\text { desenvolvimento do setor } \\
\text { financeliro }\end{array}$ & & $x$ & & & $x$ & $\mathrm{x}$ & $\mathrm{x}$ & $x$ & $x$ & $x^{x}$ & $\mathrm{x}$ & $x$ \\
\hline & \begin{tabular}{|l}
$\begin{array}{l}\text { Politica regulatória de âmbito } \\
\text { nacional }\end{array}$ \\
in
\end{tabular} & $x$ & $x$ & $\times$ & $\mathrm{x}$ & $\mathrm{x}$ & $x$ & $x$ & $x$ & $x$ & $x$ & $x$ & $x$ \\
\hline \multirow{3}{*}{$\begin{array}{c}\text { Restriçôes } \\
\text { operacionais }\end{array}$} & $\begin{array}{l}\text { Politicic protecionista e } \\
\text { discriminatória para } \\
\text { consolidar dominância }\end{array}$ & & $x$ & & & $\mathrm{x}$ & $x$ & $\mathrm{x}$ & $\mathrm{x}$ & & x & $\mathrm{x}$ & $\mathrm{x}$ \\
\hline & 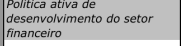 & & $\mathrm{x}$ & $\mathrm{x}$ & & $x$ & $\mathrm{x}$ & $x$ & 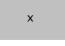 & & 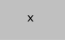 & $\mathrm{x}$ & $x$ \\
\hline & $\begin{array}{l}\begin{array}{l}\text { Polltica regulatória de âmbito } \\
\text { nacional }\end{array} \\
\text { a }\end{array}$ & $\mathrm{x}$ & $\mathrm{x}$ & $\mathrm{x}$ & $\mathrm{x}$ & $\mathrm{x}$ & $\mathrm{x}$ & $\mathrm{x}$ & $x$ & & $x$ & $\mathrm{x}$ & $\mathrm{x}$ \\
\hline \multirow{3}{*}{$\begin{array}{c}\text { Esquemas } \\
\text { emergenciais e de } \\
\text { salvamento }\end{array}$} & $\begin{array}{l}\text { Politica protecionista e } \\
\text { discriminatória para } \\
\text { consolidar dominância }\end{array}$ & & & & & & $\mathrm{x}$ & & $\mathrm{x}$ & & & $\mathrm{x}$ & $\mathrm{x}$ \\
\hline & $\begin{array}{l}\text { Politica ativa de } \\
\text { desenvovivimento do setor } \\
\text { financeiro }\end{array}$ & & & & & & $x$ & & $x$ & & & $\times$ & \\
\hline & \begin{tabular}{|} 
Politica regulatória de âmbito \\
nacional
\end{tabular} & $x$ & & $\mathrm{x}$ & 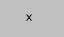 & $\mathrm{x}$ & $x$ & $\mathrm{x}$ & $x$ & & $\times$ & $x$ & $\times$ \\
\hline \multirow{3}{*}{$\begin{array}{c}\text { Restricōes a } \\
\text { transacóes } \\
\text { internacionais }\end{array}$} & $\begin{array}{l}\text { Politica protecionista e } \\
\text { discriminatória para } \\
\text { consolidar dominância }\end{array}$ & & & & & & $x$ & $\mathrm{x}$ & & & & & $x$ \\
\hline & $\begin{array}{l}\text { Politica ativa de } \\
\text { desenvvvivimento do setor } \\
\text { financeiro }\end{array}$ & & & & & & $x$ & 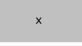 & & & & & 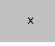 \\
\hline & $\begin{array}{l}\text { Politica regulatória de âmbito } \\
\text { nacional }\end{array}$ & & & & & & 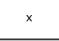 & $x$ & & & & & $x$ \\
\hline \multirow{3}{*}{$\begin{array}{c}\text { Obrigaçóes e } \\
\text { padróes de } \\
\text { ompartilihamento } \\
\text { de infraestrutura }\end{array}$} & $\begin{array}{l}\text { Pollitica protecionista e } \\
\text { discriminatória para } \\
\text { consolidar domináncia }\end{array}$ & & & & & & & & & & $x$ & $x^{x}$ & $x^{x}$ \\
\hline & 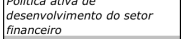 & & & & & & & & & & $x$ & $x$ & $x$ \\
\hline & $\begin{array}{l}\begin{array}{l}\text { Politica regulatória de âmbito } \\
\text { nacional }\end{array} \\
\text { in }\end{array}$ & & & & & & & & & & 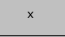 & $x$ & $x$ \\
\hline \multirow{3}{*}{$\begin{array}{l}\begin{array}{l}\text { Políticas setoriais } \\
\text { de } \\
\text { desenvolvimento }\end{array}\end{array}$} & $\begin{array}{l}\text { Politica protecionista e } \\
\text { discriminatória para } \\
\text { consolidar dominância }\end{array}$ & & $\times$ & $x$ & & $x$ & $x$ & $\mathrm{x}$ & $\times$ & & & $x$ & $\times$ \\
\hline & $\begin{array}{l}\text { Politica atva de } \\
\text { desenvolvimento do setor } \\
\text { financeiro }\end{array}$ & & $\mathrm{x}$ & $\mathrm{x}$ & & $x$ & $x$ & $\mathrm{x}$ & $\times$ & & & $\mathrm{x}$ & \\
\hline & $\begin{array}{l}\text { Politica regulatória de âmbito } \\
\text { nacional }\end{array}$ & & & & & & $\mathrm{x}$ & & $x$ & & & $\mathrm{x}$ & $x$ \\
\hline
\end{tabular}

\section{I.4. CONCLUSÃO.}

O presente capítulo apresentou reconstruções histórico-institucionais do processo de formação de cinco sistemas financeiros nacionais: Grã-Bretanha, França, Alemanha, Estados Unidos e Brasil. A narrativa dos primeiros quatro casos foi dividida em três períodos: (i) período formativo da atividade financeira, (ii) período de incentivo à industrialização, e (iii) período de reestruturação pós-crise de 1922 e guerras mundiais.

Um elemento crucial, que permeou todos os processos, foi a ativa (e criativa) intervenção do Estado. A nacionalização e o desenvolvimento dos sistemas financeiros demandou o desenvolvimento de diversos instrumentos de intervenção. Tais instrumentos foram catalogados, classificados e descritos. Também, a partir dos estudos dos cinco casos, foi possível postular que pareceram existir ao menos três grandes fatores que impulsionaram a governos nacionais a criarem sistemas financeiros nacionalizados.

Primeiro é o desejo de consolidar seu domínio sobre mercados nacionais. Isso estaria relacionado com o intuito de preservar uma base indígena de instituições 
financeiras, com cultivar subordinação e disciplina dos bancos domésticos, e com desenvolver poder de barganha para negociações com governos estrangeiros.

Em segundo lugar está e o desejo de desenvolver um setor que é instrumental na implantação de políticas públicas.. Por motivos macro e microeconômicos, políticas públicas ativas de desenvolvimento do setor foram uma característica dos processos estudado nos cinco casos.

Em terceiro lugar, está a necessidade congênita de regulação, que, por razões práticas, necessita ser implantada nacionalmente. Políticas prudenciais, de promoção da concorrência, e de ampliação do sistema de pagamentos requerem a participação de preferencialmente todos os agentes financeiros operando em território doméstico, tendo em vista seu custo e racionalidade. 
CAPÍtulo II

GOVERNOS E A INTERNACIONALIZACÃO DAS FINANCAS

\section{II.1. INTRODUÇÃO.}

Este capítulo analisará alguns dos processos que contribuíram ou estão a contribuir, na atualidade, para o aumento da porosidade dos Sistemas Financeiros Nacionais: os chamados processos de integração financeira.

Tais arranjos jurídico-institucionais têm motivações plurais, estruturas diversas e resultados assimétricos. Governos nacionais permitem, neles embarcam e deles usufruem (e, por vezes, com eles sofrem) por múltiplas razões, de variadas formas, e com diferentes conseqüências. Tais processos, todavia, têm como característica unificadora o fato de que estão a permitir o desenvolvimento de formas pelas quais a propriedade e a localização de ativos financeiros começam a divergir. Em outras palavras, estão a esgarçar o princípio organizador da lógica dos Sistemas Financeiros Nacionais, qual seja, a de que governos nacionais controlam, direta ou indiretamente, a atividade financeira em seu território.

Propõe-se aqui que processos de integração são conseqüência da atividade exercida por governos nacionais no enfrentamento de crises financeiras de grande porte, $\mathrm{e}$ de programas de modernização da indústria financeira nacional. Tal proposição será verificada no estudo comparado dos seguintes processos de integração financeira: o processo de abertura financeira unilateral do Brasil, a formação da Área Financeira Européia única, a harmonização e convergência regulatória resultante do Acordo da Basiléia, a cooperação entre reguladores no âmbito da IOSCO, e a abertura comercial de serviços financeiros na OMC. Em cada um dos casos, o objeto da análise será a forma 
como governos nacionais equilibram a relação entre instituições financeiras domésticas e estrangeiras. Para entender esse delicado equilíbrio, será narrado o sucinto histórico jurídico-institucional dos processos, serão descritos os instrumentos jurídicos criados e utilizados, a evolução dos papéis outorgados a instituições domésticas e estrangeiras, os objetivos buscados pelos governos nacionais, e os resultados atingidos em termos de integração financeira. O objetivo do capítulo é compreender motivações, meios e conseqüências desses processos.

A estrutura do capítulo é a que se segue. O item (II.2) exporá os cinco processos de integração a serem descritos, dividindo a explanação de cada um em duas partes: (i) histórico do processo e (ii) objetivos.

Na seqüência, o item (II.3) isolará os elementos jurídico-institucionais de cada processo, explicando cada um de seus arranjos, componentes e principais dispositivos. Iniciará por apresentar em detalhes a estrutura jurídica em cada um deles, classificandoos segundo o tipo predominante. Uma das razões pelas quais os casos foram escolhidos foi sua representatividade: a abertura financeira brasileira foi, em grande medida, unilateral; a integração financeira na União Européia têm fortes componentes de mútuo reconhecimento; o acordo da Basiléia baseia-se fortemente num processo de harmonização regulatória; o regime da IOSCO tem fortes componentes de cooperação administrativa; e o Acordo sobre Serviços Financeiros na OMC é um moderno caso de abertura comercial no setor financeiro. Na seqüência, enfatizar-se-á que duas motivações parecem ser predominantes nos casos estudados para que governos nacionais se envolvam em processos de integração financeira: crises econômicas e projetos de modernização. 


\section{II.2. INTERNACIONALIZACC̃̃O DAS FINANCCAS.}

\section{II.2.1. LIBERALIZAÇÃO UNILATERAL E REFORMAS FINANCEIRAS: O BRASIL EM BUSCA DE ESTABILIDADE ECONÔMICA.}

O caso primeiro processo de integração financeira a ser reconstruído tem natureza unilateral. Trata-se da abertura financeira promovida pelo governo brasileiro durante a segunda metade da década de 1990.

\section{II.2.1.1. Histórico do processo de integração.}

No início da década de 1990 o sistema financeiro nacional brasileiro ainda preservava a maior parte das características herdadas dos períodos anteriores: (i) grande participação direta do Estado; (ii) concentração; (iii) fechamento e baixa presença estrangeira; (iv) dominância do setor bancário e reduzida importância dos mercados de capitais; (v) relativa sofisticação e profundidade.

Durante todo o período de recessões e crises, o negócio bancário permaneceu estável lucrativo $^{71}$. Em verdade, entre 1980 e 1990, época chamada por muitos de "década perdida", bancos brasileiros eram ilhas de tranqüilidade num mar de calamidades. Em primeiro lugar, as altas taxas de inflação foram um grande impulso à "bancarização": a oferta de aplicações e produtos financeiros indexados, que permitiam compensar os efeitos da perda de valor da moeda, fez da classe média usuária intensiva de serviços bancários. Abrir contas, aplicar no overnight ou adquirir títulos e cotas de fundos corrigidos pela inflação tornou-se bastante comum. Em segundo lugar, ampliou-se a utilização do sistema bancário para realizar pagamentos: dinheiro vivo desvalorizava-se muito rápido, quanto mais a população mantivesse seus rendimentos em bancos, tanto menos perder-se-ia. Ganhos, portanto, com serviços secundários e tarifas bancárias eram relativamente altos. No período, investimentos em sistemas de pagamentos e automação foram grandiosos. Em terceiro lugar, déficits públicos e a crescente necessidade de financiamento por parte do governo fizeram com que o mercado de dívida pública interna crescesse vertiginosamente, e, com ele, os juros e os lucros bancários. Em quarto lugar, a

\footnotetext{
${ }^{71}$ Vide, por exemplo, (Cysne 1998; Carlos Eduardo Carvalho 2003; Hermann 2002; Luiz Fernando de Paula 1998; Luis Fernando R. Paula 2004; Luis Fernando R. Paula and Marques 2006).
} 
estrutura concentrada, verticalizada e isolada de pressões internacionais sob as quais os bancos operavam permitia grande diversificação de risco, e proteção contra a competição. Bancos, de meros intermediários, tornaram-se também grandes investidores, controlando uma grande gama de ativos não-financeiros e formando conglomerados giganatescos. A óbvia conseqüência foi o inchaço: durante o período, a participação do setor financeiro no PIB era de $15 \%$ em $1993^{72}$.

Havia certa acomodação dos diversos níveis de governo em relação a essas características. O raciocínio era simples: por serem controladores de bancos comerciais públicos, o governo federal e os governos estaduais beneficiavam-se em grande medida desse contexto. Tinham acesso facilitado a financiamento, por um lado, e recebiam os proventos de lucrativas operações de seus bancos comerciais, por outro.

A primeira ruptura em relação a esse modelo foram as chamadas reformas de $1987 / 1988^{73}$. As principais mudanças introduzidas foram as seguintes. Em primeiro lugar, extinguiu-se o instrumento da carta-patente e permitiu-se a criação dos chamados bancos múltiplos. Essa última medida implicou um golpe na política de segmentação de mercado. Em segundo lugar, permitiu-se que fundos e empresas estrangeiras passassem a investir em renda fixa no Brasil. Posteriormente, em 1991, essa autorização foi ampliada para investimentos em bolsa de valores e na compra de ações de empresas privatizadas.

Um grande empecilho, todavia, à volta dos investidores internacionais eram as reminiscências da Crise da Dívida da década de 1980. Em vista da inadimplência das obrigações internacionais, instituições financeiras estrangeiras mostravam-se reticentes em negociar com o governo e com empresas brasileiras - não, ao menos, sem impor condições não punitivas.

Grandes mudanças, no entanto, vieram com o Plano Real, as reformas liberalizantes e o programa de estabilização implantados a partir do meio da década de 1990. Cinco foram seus pilares ${ }^{74}$ : (i) controle da inflação; (ii) privatização; (iii) abertura ao investimento estrangeiro; (iv) abertura comercial; (v) ajuste fiscal ${ }^{75}$. Esse programa de

\footnotetext{
${ }^{72}$ Vide (Luis Fernando R. Paula 2004).

${ }^{73}$ Vide (Carlos Eduardo Carvalho 2003; Cysne 1998; Luis Fernando R. Paula 2004).

${ }^{74}$ Vide (Anaya 2003; Armijo 2005; Armijo and Faucher 2002; Averbug 2002; Marcus Faro de Castro and Maria Izabel Valladao de Carvalho 2003; Cysne 1998; Franco 1995; Mollo and Saad-Filho 2006; Pinheiro, Giambiagi, and Moreira 2001; Purcell and Roett 1997; Samuels 2003).

${ }^{75}$ Vide, por exemplo, (Cysne 1998).
} 
reformas, inicialmente de natureza macroeconômica, teve efeitos poderosos sobre o sistema financeiro. Em primeiro lugar, para serem efetivadas com sucesso, gerarem receitas e atraírem propostas financeiras viáveis, as privatizações necessitavam financiamento. Todavia, o capital era escasso nos mercados domésticos tendo em vista o aperto fiscal pelo qual o governo passava. Foi necessário, assim, atrair investimentos estrangeiros, o que demandou a retirada de diversas barreiras regulatórias à entrada de capitais vindos do exterior. Contribuiu também com a mudança de humor dos investidores estrangeiros a renegociação da dívida externa, concluída em 1994 com a conclusão do chamado Plano Brady. Com mais essa página virada, mais recursos externos puderam ser atraídos, e com o dinheiro estrangeiro vieram também instituições financeiras estrangeiras.

Em segundo lugar, privatização, investimento estrangeiro e abertura comercial implicaram um choque de concorrência que obrigou empresas domésticas a aumentarem sua competitividade. Isso fez com que a procura por crédito aumentasse. Com isso, aumentou a pressão sobre os bancos, que passaram a ser vistos como grande gargalo para o crescimento da economia. Com isso, reduziu-se o apoio político à proteção do setor financeiro doméstico. A liberalização da entrada de bancos estrangeiros passou a ser defendida como medida para melhorar a eficiência geral do mercado de crédito brasileiro.

Em terceiro lugar, com o final abrupto da inflação, quase que da noite para o dia desapareceu uma grande fonte de renda do sistema bancário: o chamado float (manutenção no passivo dos bancos de saldos não-remunerados, que, aplicados, rendiam algo próximo à correção monetária) ${ }^{76}$. A tabela abaixo, retirada de Paula ${ }^{77}$ mostra a importância dessa queda. Alguns bancos, menos eficientes, passaram a sentir sua receita ser comprimida, o que os levou em diversos casos a prejuízos. Bancos públicos e privados foram igualmente atingidos, sendo que os mais ineficientes sofreram mais.

\footnotetext{
${ }^{76}$ Vide, por exemplo, (Luis Fernando R. Paula and Marques 2006).

77 Vide (Luis Fernando R. Paula 2004).
} 


\begin{tabular}{|c|c|c|c|c|c|c|}
\hline \multicolumn{7}{|c|}{ Receitas inflacionárias das instituições bancárias (\%) } \\
\hline Ano & Privado & Público & Total & Privado & Público & Total \\
\hline 1990 & 1.4 & 2.6 & 4 & 31.3 & 38.7 & 35.7 \\
\hline 1991 & 1.4 & 2.4 & 3.8 & 34.7 & 46.5 & 41.3 \\
\hline 1992 & 1.7 & 2.3 & 4 & 31.3 & 55.5 & 41.9 \\
\hline 1993 & 1.6 & 2.7 & 4.3 & 19.6 & 67.7 & 35.3 \\
\hline 1994 & 0.7 & 1.3 & 2 & 11.1 & 38.4 & 20.4 \\
\hline 1995 & 0 & 0.1 & 0.1 & -0.9 & 2.5 & 0.6 \\
\hline
\end{tabular}

Em quarto lugar, o ajuste fiscal demandou medidas de controle de gasto e dívida de estados, o que incluiu restrições ao relacionamento entre os bancos estaduais e respectivos governos controladores. Bancos estaduais, já em muito prejudicados pelas condições econômicas gerais, perderam parte da garantia implícita de que seriam salvos pelo governo federal. Agravando a situação, a crise fiscal atingiu seus controladores e maiores devedores - os governos estaduais. Isso foi duplamente prejudicial à saúde dos balanços dos referidos bancos: de um lado, como controlador, o governador estadual pressionava para receber mais dividendos; do outro, como devedor, declarava calote e repúdio a dívidas contraídas. Com isso, problemas de caixa agravaram-se, e faltou crédito para refinanciar posições a descoberto.

Duas grandes crises instalaram-se no mercado financeiro brasileiro, apontando para a possibilidade de ocorrência de uma crise sistêmica. A primeira crise foi de solvência e liquidez bancária. Bancos descapitalizados, depósitos em baixa, créditos podres e fraudes em instituições bancárias de importância sistêmica colocaram o sistema financeiro sob tensão. Juros interbancários subiram, reservas reduziram-se. A segunda crise, todavia, foi de confiança. Aumentou o perigo de corrida bancária e perda massiva de recursos no sistema bancário. Ações rápidas e eficazes tornaram-se necessárias para também para assegurar ao público poupador que as instituições financeiras brasileiras em geral eram sólidas.

As ações do governo foram vigorosas ${ }^{78}$. Primeiro, tratou-se de oficializar a implementação do Acordo da Basiléia sobre requisitos mínimos de capital, por meio da Resolução 2.099/94. Em segundo, foi decretada intervenção em uma série de bancos públicos e privados, que foram colocados sob Regime de Administração Especial Temporária (RAET). O RAET era um instrumento jurídico criado pelo Decreto-lei 2.321

\footnotetext{
${ }^{78}$ Vide (Beck, Crivelli, and Summerhill; Carlos Eduardo Carvalho 2003; Cysne 1998; Hermann 2002; Lundberg 1999; Luis Fernando R. Paula 2004; Luis Fernando R. Paula and Marques 2006)..
} 
de 25.02.87 que, mais brando que intervenção, permitia o uso de recursos públicos para realização de empréstimos a bancos com problemas de liquidez. Os casos mais significativos foram os do BANESPA e do BANERJ, os dois maiores bancos estaduais pertencentes, respectivamente, ao governo do estado de São Paulo e do Rio de Janeiro, e dos bancos Econômico e Nacional, instituições privadas líderes no mercado da Bahia e em Minas Gerais, respectivamente.

Segundo, com o agravamento da crise, foi criado o PROER - Programa de Estímulo à Reestruturação e ao Fortalecimento do Sistema Financeiro Nacional. O elemento mais importante desse programa era a criação de uma linha de financiamento do Banco Central que permitia que fossem oferecidas condições mais vantajosas para que instituições financeiras de melhor saúde absorvessem instituições fragilizadas. Em outras palavras, uma linha de crédito subsidiado para apoiar a fusão ou aquisição de bancos problemáticos em prol da higidez do sistema financeiro. Outra medida importante foi a criação do Fundo Garantidor de Crédito (FGC), um fundo alimentado com recursos de todas as instituições financeiras que serviria de seguro aos depositantes em geral.

A terceira medida foi o PROES - Programa de Incentivo à Redução do Setor Público Estadual na Atividade Bancária. O principal objetivo do PROES era a redução da participação do estado (leia-se governos estaduais) no sistema financeiro. Virtualmente todos os bancos estaduais à época apresentavam problemas de caixa, por um lado, e haviam sido proibidos de emprestar recursos aos governos controladores, por outro. $\mathrm{O}$ PROES fornecia condições privilegiadas de crédito aos governos estaduais, muito endividados à época, caso cumprissem uma das quatro condições, a saber: (a) liquidassem seus bancos estaduais controlados; (b) permitissem que o governo federal os privatizassem; (c) privatizassem os bancos por conta própria; (d) reestruturassem suas instituições financeiras controladas, transformando-os em agências de fomento.

A quarta medida foi flexibilizar a entrada e participação de capital estrangeiro para adquirir instituições financeiras no território nacional. Em função do Art. 52 das disposições transitórias da Constituição de 1988, o aumento da participação estrangeira no mercado financeiro nacional estava vedado até a regulamentação do art. 192 da CF/88 sobre o Sistema Financeiro Nacional. Todavia, a vedação não se aplicava a autorizações resultantes de acordos internacionais, reciprocidade, ou interesse do governo brasileiro. 
Editou-se, então, a Exposição de Motivos n.3116, que declara ser do interesse do governo a maior participação estrangeira. Pedidos de estrangeiros de estabelecimento no mercado doméstico passaram a ser analisados caso-a-caso.

Com o PROES em marcha e as autorizações para a participação de bancos estrangeiros garantida, iniciou-se um grande processo de privatização bancária. Instituições privadas nacionais e estrangeiras assumiram os bancos estaduais, a concentração financeira aumentou ainda mais, e a participação estrangeira tornou-se mais relevante. Em agosto de 1996, havia 36 instituições financeiras estaduais, 23 delas eram bancos múltiplos ou comerciais. Já em 1998, 10 tinham sido extintas, 6 privatizadas pelos governos estaduais, 7 federalizadas para posterior privatização, e apenas 3 não participaram do programa ${ }^{79}$. Bancos importantes como o BANESPA, o Econômico, o Bamerindus, e, mais recentemente, o Real, foram à época adquiridos, respectivamente, por Santander, Bilbao-Vizcaya, HSBC e ABN-Amro.

\section{II.2.1.2. Objetivos do processo de integração e papéis reservados para as instituições financeiras domésticas e estrangeiras.}

Três objetivos para o processo unilateral de integração brasileiro podem ser identificados: (i) atrair capital estrangeiro para recapitalizar instituições domésticas problemáticas e evitar uma grande crise financeira; (ii) sinalizar aos investidores internacionais que um processo de abertura e modernização econômica estava em curso, e que o setor financeiro nacional era estável; (iii) fortalecer o braço privado do setor financeiro nacional, reduzindo a dependência das empresas em relação ao financiamento público e aumentando a eficiência da indústria financeira no geral.

\section{II.2.1.2.1. Recapitalizar instituições domésticas problemáticas e evitar crise financeira.}

O primeiro objetivo que pode ser depreendido do relato acima sobre o processo unilateral de integração financeira brasileira é levantar fundos para capitalizar instituições financeiras domésticas com problemas de balanço e de liquidez, e reduzir a possibilidade de ocorrência de crise financeira. Principalmente no período pós-Plano Real, era necessário um profundo programa de reforma financeira que, no curto prazo, pudesse

\footnotetext{
${ }^{79}$ Vide (Lundberg 1999; Beck, Crivelli, and Summerhill; Nakane and Weintraub 2005).
} 
auxiliar a prevenir a desestruturação do sistema financeiro nacional, no médio prazo implementasse melhores práticas bancárias, esquemas de supervisão e garantia de crédito mais eficazes, e, no longo prazo, colocasse as instituições operando no mercado doméstico em patamar prudencial semelhante às instituições estrangeiras.

Nessa perspectiva, ao liberalizar a entrada de instituições estrangeiras ao mesmo tempo em que construía um quadro regulatório prudencial mais efetivo e uma estrutura de mercado mais aberta, o governo brasileiro interessava-se por mobilizar investidores para recapitalizar instituições locais, reduzir os custos para o erário das políticas anticrise, reduzir o custo social das falências dos bancos problemáticos, e aumentar a eficiência e segurança do sistema financeiro nacional. Aos estrangeiros, portanto, foram reservados três papéis essenciais. O primeiro era de injetar capital nas instituições descapitalizadas. O segundo era de assumir o controle e administração de bancos domésticos, públicos ou privados, de importância sistêmica, modificando sua administração, instalando melhores práticas, recuperando a confiabilidade, e emprestando sua reputação de solidez. A terceira era pressionar as instituições domésticas a competirem mais, por um lado, e a adotarem boas práticas bancárias internacionais, por outro, facilitando a aplicação de requisitos e padrões regulatórios internacionais. Aos bancos privados locais foi reservado o papel de concorrer com os bancos estrangeiros, modernizando-se, baixando os custos de capital, desenvolvendo novos produtos e expandido mercados, e aumentando a eficiência geral do sistema. Outrossim, os atores domésticos privados e públicos tinham um grande papel na manutenção de um sistema de pagamentos eficiente, coeso e estável, que fosse aberto, integrado e que servisse indiscriminadamente a todas as instituições financeiras.

\section{II.2.1.2.2. Recuperar a confiança dos investidores internacionais e construir uma reputação de solidez.}

O segundo objetivo que pode ser identificado no relato do histórico do processo de integração financeira unilateral brasileira é recuperar a confiança dos investidores estrangeiros e criar reputação de ambiente mais acolhedor para investimento internacional. Após a crise da dívida na década de 1980, os mercados financeiros internacionais fecharam-se, em certa medida, a captações brasileiras. O programa de estabilização, abertura e modernização da economia na forma definida pelo banco central 
demandava um grande ajuste fiscal, significando que o governo perderia, em grande medida, seu poder de investimento. Assim sendo, atrair capitais internacionais era essencial para manter um ritmo de crescimento econômico aceitável e compatível com a necessidade de transformação da economia.

Nessa perspectiva, um papel essencial reservado às instituições financeiras estrangeiras era o de servir de fiadoras do processo de modernização da economia brasileira. $\mathrm{O}$ aumento da exposição do sistema financeiro nacional a atores internacionais era visto como elemento essencial à estratégia de internacionalização brasileira. A presença de bancos estrangeiros permitiria a produção de informações mais acuradas sobre a economia, reduzindo a assimetria de informação entre nacionais e estrangeiros. Além disso, por exporem-se mais ao Brasil, bancos estrangeiros poderiam auxiliar no desenvolvimento de novos negócios, na identificação de oportunidades, e na intermediação entre clientes brasileiros e estrangeiros. Por fim, a ação de assegurar a presença e operação de estrangeiros no pais em igualdade de condições em relação às instituições domésticas seria per se importante e relevante, posto que implicaria sinalização muito forte do compromisso brasileiro em criar um ambiente de investimentos, competitivo, livre de discriminação, balanceado, estável e equilibrado. Às instituições financeiras domésticas, nesse caso, foi reservado o papel de firmar parcerias e fazer negócios com as estrangeiras, exercendo atividades complementares, coletando clientes e desenvolvendo relacionamentos.

\section{II.2.1.2.3. Fortalecer o setor financeiro privado.}

O terceiro objetivo encontrado no relato é fortalecer o braço privado do setor financeiro nacional, reduzindo sua dependência dos cofres públicos e de subsídios, e aumentando a eficiência da indústria financeira no geral. Com o setor público descapitalizado e incapacitado pela necessidade de realizar o ajuste fiscal, o fornecimento de crédito e o financiamento da atividade econômica passou a depender da atuação forte dos bancos privados. Todavia, considerava-se que anos de funcionamento simbiótico com os bancos públicos e os ganhos fáceis do float teriam distorcido o negócio bancário no Brasil, fazendo com que a indústria financeira nacional não estivesse preparada para funcionar eficientemente em ambiente de estabilidade econômica. Além disso, caso as privatizações implicassem mera alienação dos ativos públicos aos grandes grupos 
privados brasileiros, os problemas causados pela concentração bancária poderiam se agravar, gerando represamento de crédito, encarecimento da captação de recursos, e outras ineficiências. Concluiu-se que abrir o mercado para instituições financeiras internacionais serviria melhor aos propósitos da reforma financeira porque envolveria a entrada de novas instituições financeiras com fôlego, experiência e recursos para efetivamente competir com os incumbentes.

Nessa perspectiva, ao permitir que instituições financeiras estrangeiras adentrassem o mercado financeiro nacional, interessava ao governo brasileiro introduzir uma crível competição potencial, de modo a disciplinar o possível exercício de poder de mercado das instituições domésticas. Além disso, era importante garantir níveis mínimos de capital, expertise e confiabilidade. Foi, portanto, reservado aos bancos estrangeiros o papel de estimuladores da concorrência, provedores de capital novo, e introdutores de tecnologia bancária. Também se tinha em vista a necessidade de tornar as instituições domésticas mais competitivas e sofisticadas, promovendo maior inovação e uma atualização dos produtos ofertados.

\section{II.2.2. INTEGRAÇÃO FINANCEIRA EUROPÉIA: MERCADO ÚNICO E A "ÁREA FINANCEIRA EUROPÉIA $"$.}

A segunda experiência de integração financeira a ser analisada tem natureza plurilateral. Trata-se do longo processo de formação e consolidação do Mercado Único Europeu para serviços financeiros.

\section{II.2.2.1. Histórico do processo de integração.}

Como um projeto, a integração econômica européia nasceu em 1953, com a assinatura do Tratado de $\operatorname{Roma}^{81}$. Previa como norte a consecução plena de quatro liberdades no seio da Comunidade Econômica Européia: o livre-movimento de bens,

\footnotetext{
${ }^{80}$ Quando lançou o projeto de aprofundamento do Mercado Comum Europeu, nos idos de 1987, a Comissão Européia referiu-se à remoção de barreiras a movimentos de capitais e ao estabelecimento de uma moldura regulatória de um mercado comunitário europeu para serviços financeiros como "Área Financeira Européia". Vide (Commission of the European Communities 1987).

${ }^{81}$ Vide o Tratado Estabelecendo a Comunidade Econômica Européia (European Economic Community 1957) [doravante Tratado de Roma].
} 
pessoas, serviços e capitais. O compromisso de seus seis membros iniciais ${ }^{82}$ era o de “estabelecer um mercado comum e progressivamente aproximar as políticas econômicas dos Estados Membros" $"$. Todavia, nos primeiros trinta anos, a Comunidade centrou suas preocupações em tarifas sobre bens, harmonização de imposto sobre valor agregado, e fortalecimento da união aduaneira. Somente em 1979 foi criado o Sistema Monetário Europeu (SME), e o foco de seu estabelecimento era facilitar as trocas comerciais em moedas européias ${ }^{84}$.

Com a incorporação, em 1973, de mais três membros ${ }^{85}$, maiores problemas de coordenação surgiram. A garantia de dois direitos derivados do Tratado de Roma, a liberdade de estabelecimento ${ }^{86}$ e a liberdade de fornecimento de serviços ${ }^{87}$, não tinha se efetivado. Além disso, a grande recessão causada pelo primeiro choque do petróleo (1973) e agravada pelo segundo (1979) criaram grande pressão para que reformas econômicas fossem implantadas. Era agudo o sentimento de que o dinamismo havia deixado a Europa e que as crises econômicas apontavam para um período de declínio da pujança do velho continente ${ }^{88}$. Estados Unidos e Japão recuperavam-se mais rapidamente da desaceleração econômica; questões relativas ao orçamento da Comunidade, à Política Agrícola Comum (PAC), e ao uso de barreiras não-tarifárias ao comércio de bens passaram dividir os governos nacionais ${ }^{89}$.

Impulsionar o processo de integração em geral, e dos mercados financeiros, em específico, eram vistos como sendo partes essenciais de uma estratégia visando a tirar a Europa da estagnação. O maior entrave, no entanto, eram as regras nacionais que, segundo se argumentava, fragmentavam o espaço europeu e permitiam a subsistência de mercados nacionais. Experiências prévias de harmonização, como a Primeira Diretiva

\footnotetext{
${ }^{82}$ Alemanha Ocidental, Bélgica, França, Itália, Luxemburgo, e Países Baixos.

${ }^{83}$ Art. 1 do Tratado de Roma.

${ }^{84}$ Vide (Key 1989; Osborne 1993)

85 Dinamarca, Irlanda e Reino Unido.

${ }^{86}$ Direito de uma pessoa natural ou empresa, nacional de um Estado-Membro da Comunidade, de criar um negócio ou estabelecer filiais, agencias, ou subsidiárias no território de outro Estado-Membro.

${ }^{87}$ Direito de uma pessoa natural ou empresa, nacional de um Estado-Membro da Comunidade, de fornecer serviços no território de outro Estado-Membro sem precisar se estabelecer em tal Estado.

${ }^{88}$ Vide (Key 1989).

${ }^{89}$ Vide (Commission of the European Communities 1985; Key 1989; Osborne 1993; Barry Eichengreen 2008b, 336-337).
} 
Bancária $^{90}$, que estabelecia uma regulação harmonizada dos procedimentos para autorizar o funcionamento de "instituições de crédito", tinham se mostrado complexas tecnicamente, demasiado onerosas politicamente, e limitadas em excesso. Nesse contexto, a Comissão Européia propôs uma nova abordagem almejando a acelerar a redução de restrições à livre circulação de bens, serviços, capitais e pessoas dentro da área econômica européia ${ }^{92}$. Tal proposta foi encampada pelo Conselho Europeu, sendo transformada em normativa européia pelo Ato Único Europeu de $1986^{93}$.

O Ato Único Europeu estabeleceu um ambicioso programa para a criação de "uma área sem fronteiras internas em que o livre movimento de bens, pessoas, serviços e capital [seria] assegurado" 94 . Tal programa, por prever como data-limite 31 de dezembro de 1992, foi chamado de "Programa 1992". Em matéria financeira, seu coração era a Segunda Diretiva Bancária ${ }^{95}$ de 15 de dezembro de $1989^{96}$. Seus pontos principais eram $^{97}$ : (1) estabelecer critérios mínimos para autorização de instituições de crédito; (2) introduzir o conceito de "autorização bancária única" (também chamado de "passaporte único"); (3) política comum em relação a instituições de crédito de terceiros países; (4) harmonização mínima dos requisitos prudenciais; (5) limitada harmonização de medidas de proteção ao consumidor.

No início da década de 1990, todavia, uma outra evolução teve lugar. Os desequilíbrios entre as políticas monetárias e cambiais dos principais membros das Comunidades Européias tornou à agenda política, e um movimento com o objetivo de criar uma moeda única européia ganhou força ${ }^{98}$. Negociações políticas levaram a um plano de três estágios: (1) 1990-1993: coordenação monetária, remoção de controles de

${ }^{90}$ Vide (Council of the European Communities 1977).

${ }^{91}$ Considerando as diversas definições nacionais para instituições financeiras ou bancos, o Conselho Europeu cunhou a expressão "instituições de crédito" para abarcá-las todas.

${ }^{92} \mathrm{O}$ bojo dessa proposta está contida no documento chamado Completing the Internal Market: White Paper (Commission of the European Communities 1985). Vide também o Comunicado sobre a Criação da Área

Financeira Européia (Commission of the European Communities 1987).

${ }^{93}$ Vide (European Economic Community 1987)

${ }^{94}$ Artigo 8A do Ato Único Europeu (European Economic Community 1987).

${ }^{95}$ Vide (Council of the European Communities 1989b).

${ }^{96}$ Outras Diretivas também fazem parte do Programa Financeiro 1992. Vide, entre outras, a Diretiva sobre Fundos Próprios (Council of the European Communities 1989a), Diretiva sobre a Índices de Solvência (Council of the European Communities 1989c), a Diretiva sobre Monitoramente e Controle de Grandes Exposições (Council of the European Communities 1992), e a Diretiva sobre Adequação de Capital (Council of the European Communities 1993).

${ }^{97}$ Uma discussão mais aprofundada será feita abaixo no item II.3.2.2.

${ }^{98}$ Para um histórico mais detalhado do processo, vide (Barry Eichengreen 2008b, 346-357). 
capitais, e reforço da independência dos bancos centrais nacionais; (2) 1994-1999: maior convergência, criação do Instituto Monetário Europeu, e ajustes para garantir a viabilidade da nova moeda; (3) 1999-em diante: união monetária. Tal plano foi inscrito no Tratado de Maastricht ${ }^{99}$, assinado em 1992. O restante da década foi consagrado a uma intensa preparação institucional tendo em vista permitir a introdução do euro ${ }^{100}$. Foi decidido isso deveria acontecer em 1 de janeiro de 1999.

Com a data da adoção do euro aproximando-se, o Conselho Europeu calculou que uma janela para o lançamento de um novo período de reformas poderia surgir. Na reunião de Cardiff, em 1998, o Conselho solicitou que a Comissão Européia apresentasse uma moldura para aprimorar o mercado único em serviços financeiros ${ }^{101}$. Durante todo o processo, crises financeiras sucessivas aconteceram. Em 1991, uma grande recessão ocorreu na Europa; o Sistema Monetário Europeu enfrentou grandes turbulências em 1992, sendo que a libra britânica, sob intenso ataque especulativo, teve de deixar o Mecanismo Europeu de Câmbio ${ }^{102}$. No final do período seguiu-se um ambiente de crise financeira internacional (a crise asiática de 1997 e a crise russa de 1999), e aumentou a percepção de que a indústria financeira européia deixava a desejar em relação à norteamericana $^{103}$. Como resposta ao mandato recebido, a Comissão elaborou o Plano de Ação sobre Serviços Financeiros ${ }^{104}$.

Diferentemente do Programa 1992, que enfatizava as instituições de crédito, o Plano de Ação focava principalmente nos mercados de valores mobiliários e derivativos, nas bolsas de valores, nas instituições provedoras dos chamados "serviços de investimento". Foram arroladas as seguintes prioridades ${ }^{105}$. Para mercados de atacado: (1) regras comuns para mercados financeiros; (2) reduzir barreiras para que empresas levantassem capital por toda a Europa; (3) harmonizar regras para demonstrações

\footnotetext{
${ }^{99}$ Vide (European Union 1992).

${ }^{100}$ O Tratado de Maastricht não previa um nome para a nova moeda. A denominação "euro" foi escolhida em 1995.

${ }^{101}$ Diz o Parágrafo 17 das Conclusões Presidenciais do Conselho: "The European Council therefore (...) invites the Commission to table a framework for action by the time of the Vienna European Council to improve the single market in financial services" (Council of the European Union 1998).

${ }^{102}$ Respectivamente, EMS - European Monetary System e ERM - European Exchange Rate Mechanism. Para um relato da crise monetária européia, vide (Barry Eichengreen 2008b, 357-366).

${ }^{103}$ Vide (Commission of the European Union 1998, 1-3)

${ }^{104}$ Vide (Commission of the European Union 1999).

${ }^{105}$ Vide (Commission of the European Union 1999, 5-15)
} 
financeiras; (4) moldura regulatória unificada para fundos de pensão; (5) regras para garantias; (6) melhor e mais transparente ambiente para reestruturações societárias. Para mercados de varejo: (1) informação e transparência nos mercados de capitais; (2) regras para proteção de investidores; (3) aplicação balanceada das regras de proteção ao consumidor; (4) comércio eletrônico; (5) seguros; (6) pagamentos transfronteiriços.

O coração do Plano de Ação é a Diretriz sobre Mercados em Instrumentos Financeiros (MiFID) ${ }^{106}$, de 21 de abril de $2004^{107}$. Ela prevê (1) "passaporte único" para as empresas cobertas; (2) categorização dos clientes para efeitos de proteção do consumidor; (3) regras para direcionamento de operações em bolsa de valores; (4) transparência pré e pós-negócio em bolsa de valores; (5) regras de melhor execução de operações em bolsa; (6) regras para agentes, corretores e distribuidores de ações.

\section{II.2.2.2. Objetivos do processo de integração e papéis reservados para as instituições financeiras domésticas e estrangeiras.}

Três objetivos para o processo de integração europeu podem ser identificados: (i) fortalecer bancos europeus na saída de grandes crises financeiras, (ii) promover a modernização das instituições financeiras operando na Europa, e (iii) promover o aumento de competitividade das instituições financeiras européias no mercado global.

II.2.2.2.1. Recapitalizar o sistema bancário, implantar políticas de relançamento econômico e facilitar a estabilização econômica.

O primeiro objetivo que pode ser encontrado no relato sobre o processo de integração financeira europeu é facilitar a superação de crises econômicas bastante sérias por que passou o continente. Principalmente no período dos grandes choques do petróleo (1973-1979), mas também no pós-crise asiática e russa, estavam presentes as idéias de que uma maior integração financeira entre os países europeus poderia gerar um aumento da estabilidade macroeconômica, e de que seria mais rápida a recuperação das crises.

\footnotetext{
${ }^{106}$ Vide (European Parliament and Council of the European Union 2004). [Doravante MiFID].

${ }^{107}$ Um programa bastante extenso de diretrizes, ainda mais do que no Programa 1992, teve de ser implantado para poder transpor o Plano de Ação. Vide (Commission of the European Union 1999).
} 
Nessa perspectiva, ao permitir que instituições financeiras de outros países europeus adentrassem seus mercados domésticos, interessava aos governos nacionais europeus atrair capital externo, promover instituições mais saudáveis, e reduzir os custos domésticos de combater a crise. Em grande medida, são essas as razões políticas que levaram os governos nacionais representados no Conselho das Comunidades Européias e no seu sucessor, Conselho da Europa, a impulsionar o processo de integração e respaldar as ações da Comissão Européia. Aos mais fortes bancos europeus, portanto, estava reservado o papel de recapitalizar instituições domésticas com problemas, modificar a governança de instituições problemáticas, e reduzir restrições de crédito. Aos bancos domésticos em dificuldades, restou o papel de aliarem-se à grandes instituições européias e contribuírem para o ajuste. Bancos estrangeiros vindos de países terceiros não tiveram papel relevante no processo. Não foi observada uma intensa onda de fusões e aquisições transatlântica no período.

II.2.2.2.2. Incentivar a absorção de tecnologia, desenvolvimento de novos produtos e redução de preços.

O segundo objetivo que pode ser depreendido do relato acima é impulsionar a modernização da indústria financeira européia. Principalmente em relação ao Plano de Ação, é visível a preocupação com incentivar a incorporação de inovações técnicas e tecnológicas, criando instituições e mercados com massa crítica para permitir investimentos em desenvolvimento de novos produtos.

Nessa perspectiva, interessava aos governos nacionais permitir que instituições financeiras de outros países europeus, com maior know-how e maior gama de produtos, adentrassem seus mercados domésticos e operassem em território nacional. Aos mais inovativos e maiores bancos europeus estava reservado o papel de difundir tecnologia e desenvolver novos mercados para produtos financeiros, oferecendo a clientes por toda Europa acesso a produtos financeiros sofisticados. Aos bancos domésticos restou o papel de aliarem-se ou servirem de veículos para o aprofundamento dos mercados financeiros. Bancos estrangeiros vindos de países terceiros provinham a pressão para promover um ambiente inovador.

II.2.2.2.3. Aumentar a competitividade da indústria nacional frente aos estrangeiros. 
O terceiro objetivo que pode ser identificado no relato acima é promover o aumento da competitividade das instituições financeiras européias. Em ambos os principais períodos de modernização, do Programa 1992 e do Plano de Ação financeiro, é patente a ação conjunta dos governos europeus para promover aumento de escala da operação de suas instituições financeiras.

Nessa perspectiva, para um governo nacional europeu, a política de integrar mercados financeiros (mercado bancário e mercado de capitais) em nível comunitário implica ampliar o horizonte de ação das instituições financeiras domésticas sem ampliar o acesso de instituições provindas de países terceiros. Às mais fortes instituições européias foi reservado o papel de crescerem e tornarem-se competitivas, desenvolvendo musculatura para concorrer com bancos globais provenientes de países terceiros. Aos bancos domésticos de menor tamanho, restou forjarem alianças com os maiores europeus ou competir por nichos. Bancos estrangeiros de países terceiros ofereciam pressão competitiva.

\section{II.2.3. ACORdo da BaSiléia: HaRmonização e CONVERgêNCIA.}

O terceiro processo de integração financeira a ser relatado tem uma natureza bastante interessante. Apesar do Acordo da Basiléia ter se iniciado como uma acordo de harmonização regulatória de natureza plurilateral que envolvia apenas um seleto grupo de países desenvolvidos, tornou-se desde logo um projeto multilateral: foi, em pouco tempo, adotado por uma centena de países.

\section{II.2.3.1. Histórico do processo de integração.}

Em $1974^{108}$ foi criado um Comitê sobre Regulação Bancária e Práticas de Supervisão no âmbito do Banco Internacional de Compensações ${ }^{109}$. Tal comitê foi formado por representantes dos bancos centrais e supervisores bancários dos países pertencentes ao chamado G10 ${ }^{110}$. A razão inicial foi a tumultuosa falência do Herstaat

\footnotetext{
${ }^{108}$ Vide (Scott 2008, 235-318; Tarullo 2008, 45-86).

${ }^{109}$ BIS - Bank of International Settlements. [Doravante BIS].

${ }^{110} \mathrm{O}$ G10, por razões histórias era formado, na verdade, por 12 membros: Alemanha, Bélgica, Canadá, Estados Unidos, França, Itália, Japão, Luxemburgo, Países Baixos, Reino Unido, Suécia e Suíça. Espanha juntou-se ao grupo em 2001.
} 
Bank: à época, foi notado que a falta de coordenação entre supervisores bancários nacionais teria permitido ao banco multinacional driblar sua fiscalização. No ano de 1975 assinou-se a Concordata da Basiléia, que alocava a responsabilidade de supervisão entre país-origem a países hóspedes. Foi o primeiro acordo de cooperação bancária multijurisdicional assinado, garantindo que pelo menos uma autoridade no mundo faria a supervisão das atividades consolidadas de todos os bancos. A Concordata foi revisada e ganhou musculatura no final dos anos 1980 em vista do escândalo do Banco de Crédito e Comércio Internacional ${ }^{111}$, em que diversas fraudes e esquemas de evasão regulatória foram descobertos. Impressionou o vulto das operações offshore do banco, cuja fiscalização passou a ser tratada como essencial para a estabilidade internacional.

$\mathrm{O}$ comitê não tinha (e até o presente ainda não tem) personalidade jurídica internacional ou funcionários permanentes, sendo apenas um fórum de coordenação para reguladores. Chamado mais modernamente de Comitê da Basiléia sobre Supervisão Bancária ${ }^{112}$, passou a se reunir periodicamente para discutir padrões e práticas internacionais para fiscalização. Sua primeira incursão no universo das regras substantivas e da harmonização foi a adoção de requisitos mínimos de capital ${ }^{113}$. Em 1986 os Estados Unidos e o Reino Unido uniram-se para pressionar os membros europeus e japoneses do G10 e aprovar um conjunto de normas que obrigavam bancos a resguardar uma porção de seu capital que fosse proporcional ao risco dos ativos que possuíam.

Existem várias razões para que isso fosse intentado. Em primeiro lugar, está o intenso processo de competição internacional em que os bancos multinacionais envolveram-se à época. Durante as décadas de 1970 e 1980, governos nacionais haviam reduzido radicalmente controles de capitais e proibições para entrada de estrangeiros, reformando seus quadros regulatórios nacionais ${ }^{114}$. Os mercados de câmbio cresceram

\footnotetext{
${ }^{111}$ BCCI - Bank of Credit and Commerce International.

112 BCBS - Basel Committee on Banking Supervision. [Doravante BCBS].

${ }^{113}$ Requisito mínimo de capital é a porcentagem mínima de seus ativos que um banco deve resguardar, de modo a proteger-se contra inadimplência, e, ainda assim, conseguir honrar saques. Funciona como uma apólice de seguro, provê um colchão mínimo de liquidez, e permite que a instituição financeira se autoproteja de calotes.

${ }^{114}$ Alguns estudos indicam que as barreiras em países desenvolvidos caíram mais de 50\%. Para uma tabulação da entrada em vigor das reformas, vide (Kaminsky and Schmukler 2002).
} 
enormemente, assim como os de empréstimos ${ }^{115}$. Bancos japoneses, norte-americanos e europeus começaram a competir vigorosamente entre si. Isso significou menores margens de lucros, mais inovação, novos produtos e menores preços, por um lado, mas, também, mais riscos, por outro. Pode-se dizer que o surgimento de um acordo sobre requisitos mínimos resultou da operação de três forças:

- preocupação dos reguladores de todos os países do G10 com os riscos trazidos aos mercados domésticos pelas operações dos bancos estrangeiros;

- lobby dos bancos domésticos junto aos reguladores para reduzir a competição trazida pelos novos entrantes estrangeiros;

- preocupação dos reguladores norte-americanos e britânicos com a perda de competitividade das instituições financeiras anglo-saxãs diante dos bancos japoneses e continentais, que operavam sob menores restrições de capital mínimo.

Aos três fatores estruturais, juntou-se um quarto, conjuntural: a repercussões da crise da dívida de 1982. Todos os países do G10 encontravam-se numa situação de exposição: seus bancos tinham emprestado a governos de países emergentes, mas não tinham contabilizado de forma correta o risco. Para todos os governos nacionais, era necessário implantar regulação mais restritiva. Todavia, havia um problema de coordenação: os primeiros países a implantar tais regras fariam seus bancos sofrer mais e pagar uma parte maior do ajuste. Nenhum governo gostaria, portanto, de mover-se antes dos outros. Um acordo internacional evitaria esse empecilho.

As negociações foram duras, mas em julho de 1988 foi aprovado o chamado Acordo da Basiléia ${ }^{116}$. Tal acordo estabelecia fórmulas harmonizadas para (i) a definição de capital, (ii) a ponderação do risco dos ativos em posse dos bancos, (iii) requisitos mínimos de capital, estabelecidos em 8\%, e (iv) cronograma de implementação desses requisitos mínimos.

O mais impressionante de todo o processo, todavia, não foi a aprovação de regras harmonizadas para os países do G10 - foi a sua extensão para outros países. Num curto período de menos de 5 anos, mais de uma centena de países, os quais não haviam

\footnotetext{
${ }^{115}$ Sobre o crescimento do mercado de câmbio, vide (Singer 2007, 36-43). Sobre o mercado de dívida externa, vide supra, nota Error! Bookmark not defined. e texto acompanhando.

${ }^{116}$ No original em inglês, Basel Accord, que mais tarde passou a ser chamado Basiléia I (Basel I). Vide (Basle Committee on Banking Supervision (BCBS) 1988).
} 
participado das negociações do Acordo, adotaram-no de forma voluntária. A esse processo, autores dão o nome de convergência, contrastando-o com harmonização ${ }^{117}$; em harmonização há discussão e negociação direta dos standards, em convergência, não. Trata-se, portanto, de um padrão que iniciou como um acordo plurilateral, mas que se tornou rápida e verdadeiramente multilateral em pouquíssimo tempo.

Há grande discussão sobre as razões pelas quais ocorreu essa convergência. Alguns autores argumentam que as forças do mercado foram o principal fator ${ }^{118}$. Para tais autores, trata-se de uma questão de sinalização: uma vez estabelecido um padrão prudencial internacional, caso alguma jurisdição não o adotar, estará sinalizando ao restante do mercado uma pior qualidade de supervisão, e piores padrões prudenciais. Em conseqüência, seus bancos sofrerão com menor credibilidade.

Outros autores, todavia, ressaltam o papel da coerção externa e pressão de outros governos nacionais ${ }^{119}$. Dentro dessa perspectiva, o poder político e econômico de outros países, ampliado pela ação de organizações internacionais como o FMI e Banco Mundial, e aliado com a vulnerabilidades criadas por uma conjuntura econômica negativa (crise ou ameaça de crise) poderiam também ter influência no processo.

Um terceiro fator também lembrado é a exposição de bancos domésticos a mercados externos ${ }^{120}$ : considerando-se que filiais estrangeiras de bancos domésticos têm muitas vezes que seguir as regras impostas pelo país-hóspede, instituições nacionais cujas operações no exterior são vultosas têm um incentivo e uma facilidade natural para aderir a padrões estrangeiros.

\section{II.2.3.2. Objetivos do processo de integração e papéis reservados para as instituiçães financeiras domésticas e estrangeiras.}

Quatro são os objetivos identificados para o processo de adoção de regras sobre requisitos de capital: (i) reduzir riscos e garantir melhor supervisão bancária; (ii) limitar competição entre bancos nacionais e estrangeiros, (iii) diminuir o diferencial de competitividade entre bancos, principalmente japoneses, e ocidentais, notadamente norte-

\footnotetext{
${ }^{117}$ Vide infra sobre convergência e harmonização. Vide também (Singer 2004).

118 Vide (Goldstein 2000; Ho 2002; Kapstein 2006; Mosley 2003; Simmons 2006b; Singer 2007, 58-62).

119 Vide (Chey 2007).

${ }^{120}$ Vide novamente (Chey 2007).
} 
americanos e britânicos; (iv) melhorar a credibilidade dos bancos operando em território nacional.

II.2.3.2.1. Reduzir riscos e garantir melhor supervisão sobre o mercado doméstico.

O primeiro objetivo que pode ser encontrado no relato acima é coibir em nível mundial práticas excessivamente arriscadas de bancos privados, estabelecendo padrões harmonizados de cooperação e supervisão entre reguladores.

Como fiadores da saúde das instituições financeiras a que o público doméstico está exposto, governos nacionais ao redor do mundo têm um interesse compartilhado e geral de manter a higidez bancária. Nessa perspectiva, ao cooperar com autoridades estrangeiras, governos nacionais garantem quatro resultados. O primeiro é a redução de riscos sistêmicos. Com a generalização de bons padrões prudenciais, evita-se a competição regulatória, que pode impactar negativamente a operação dos bancos nacionais. Reduz-se, portanto, o risco de contágio e falências em cascata. O segundo é garantir maior segurança para bancos domésticos operando no exterior. Ao garantir que países estrangeiros adotem bons padrões prudenciais, governos nacionais contribuiriam para reduzir os riscos e a exposição de bancos nacionais. O terceiro é garantir que as instituições estrangeiras operado em território nacional tenham suas operações estrangeiras supervisionadas adequadamente, o que reduziria os riscos que tais instituições aportariam ao mercado doméstico. O quarto é evitar conflitos de jurisdição e competência, e regras contraditórias. Tais situações podem levar a falhas de supervisão, posto que instituições multinacionais têm incentivos para jogar com as regras e encontrar brechas.

Dentro dessa estratégia, portanto, o papel dos bancos adaptados aos requisitos harmonizados, sejam eles instituições domésticas ou estrangeiras, é exercer pressão sobre autoridades e bancos que não seguem os padrões internacionais.

\section{II.2.3.2.2. Limitar a competição entre bancos domésticos e estrangeiros.}

O segundo objetivo encontrado no relato acima sobre a criação de regras multilaterais sobre requisitos de capital é limitar a competição internacional entre bancos. Trata-se de uma motivação controversa: em qualquer manual ou texto básico de economia, competição é sempre apresentada como virtude, e medidas regulatórias que 
limitem a concorrência são execradas. É difícil, inclusive, apresentar uma tal política e defendê-la em público - fazê-lo implica reconhecer que o setor financeiro recebe tratamento privilegiado em relação a outros setores da economia. Todavia, historicamente, ainda que de forma sub-reptícia, governos nacionais apresentam um viés protecionista em suas políticas públicas para bancos ${ }^{121}$.

Nessa perspectiva, ao limitar o acesso de seus cidadãos a serviços financeiros providos por instituições financeiras estrangeira, governos nacionais reduzem o papel de bancos estrangeiros em seu mercado nacional. Com isso, a base doméstica de bancos é preservada. O governo ganha, assim, poder de barganha e aliados junto ao setor financeiro doméstico. A instituições financeiras nacionais é reservado o papel de apoiar suas autoridades regulatórias e coalizão no comando, seja por meio de crédito e financiamento ao governo, seja seguindo orientações. Destarte, cultiva-se subordinação e alinhamento.

II.2.3.2.3. Reduzir o diferencial de competitividade entre bancos domésticos e estrangeiros.

O terceiro objetivo depreendido do relato supra é reduzir o diferencial de competitividade dos bancos nacionais em relação aos bancos estrangeiros. Tal motivação parece bastante clara na posição norte-americana em relação aos bancos japoneses. Quando autoridades domésticas de um país A impõem regras mais severas de adequação de capital, elas reduzem de forma assimétrica a competitividade de bancos multinacionais: os bancos mais expostos ao mercado financeiro de A são mais atingidos do que os menos expostos. Por isso, instituições financeiras provenientes de mercados cujas autoridades são mais permissivas podem ter uma vantagem competitiva quando atuando em países estrangeiros: com o mesmo capital, elas podem oferecer mais empréstimos no exterior.

Nessa perspectiva, para um governo mais rigoroso, a política de estabelecer critérios multilaterais harmonizados de capital implica reduzir a desvantagem competitiva de instituições financeiras cujas principais operações encontram-se em mercados

\footnotetext{
${ }^{121}$ Alguns autores como (Moran 1986; Moran 1991) chamam esse tipo de regulação, técnica e isolada das discussões públicas, de "regulação esotérica".
} 
domésticos. Aos bancos globais baseados em países mais rigoroso foi reservado o papel de fazer pressão sobre autoridades estrangeiras a reduzir a permissividade de suas políticas. Aos bancos locais operando nos mesmos países, for reservado o papel de se aliarem aos bancos globais e pressionarem seus governos contra a competição estrangeira. Aos bancos globais com sede em países menos exigentes, cumpriu o papel de exercerem pressão competitiva e introduzirem novos produtos e inovações, conformandose, no entanto, e alinhando-se a seus concorrentes na questão do capital, evitando retaliações e ondas protecionistas.

\section{II.2.3.2.4. Melhorar a credibilidade dos bancos operando em território nacional.}

O quarto objetivo que pode ser identificado do relato acima é melhorar a credibilidade do sistema financeiro doméstico, sinalizando aos potenciais credores estrangeiros melhorias nas condições de estabilidade, qualidade institucional e higidez dos bancos locais. Como se pode depreender do discutido supra, tal objetivo foi especialmente caro aos países emergentes, principalmente aos que buscavam reabrir linhas de crédito internacionais que haviam se fechado em vista da crise da dívida e da redução de liquidez internacional provocada pelas políticas monetárias dos países centrais.

Nessa perspectiva, ao adotar unilateralmente regras negociadas entre governos de países estrangeiros, as autoridades financeiras dos países em desenvolvimento buscavam, em primeiro lugar, introduzir nos mercados domésticos aquilo o que consideravam melhores práticas internacionais. Em segundo lugar, ao fazê-lo, exibiriam inequivocamente sua disposição para tomar decisões difíceis em prol da saúde e segurança do mercado financeiro doméstico. Tal compromisso serviria para estabilizar expectativas e garantir que o risco nacional estava sendo reduzido. Aos grandes bancos locais, por isso, foi reservado o papel de adaptarem-se e fortalecerem-se, de modo a retornar à saúde financeira e alavancar empréstimos. Dadas as potenciais dificuldades que instituições menores enfrentariam para se adaptarem a critérios mais exigentes de capital, reservou-se também aos grandes bancos nacionais e aos bancos estrangeiros o papel de adquirir ou ajudar na recapitalização das instituições locais necessitadas. Dos bancos estrangeiros também se esperava que pressionassem pela adoção de regras mais 
demandantes. Finalmente, os governos de países em desenvolvimento esperavam dos governos de países desenvolvidos e das organizações financeiras multilaterais que chancelassem essa política de convergência unilateral, sinalizando a seus respectivos investidores que voltassem a confiar na recuperação dos mercados emergentes.

\section{II.2.4. IOSCO: COOPERAÇÃO ENTRE REGULADORES.}

\section{II.2.4.1. Histórico do processo de integração.}

Ao final da década de 1980 , com a redução dos controles de capitais ${ }^{122}$, restrições para investidores internacionais diminuíram de forma significativa. Investimentos passaram a cruzar fronteiras com mais freqüência, e o movimento estrangeiro em bolsas domésticas aumentou de forma significativa. Como conseqüência, aumentaram também as oportunidades para esquemas de manipulação e fraudes internacionais. Grandes problemas de segurança nos mercados foram criados: como assegurar a honestidade de investidores operando a partir de jurisdições estrangeiras? Como investigar práticas suspeitas planejadas e executadas em outros países? Como conseguir evidências, e como processar investidores operando ultramar?

$\mathrm{O}$ caso basilar, primeiro indicador de que o aumento de fluxos internacionais poderia criar problemas, foi BSI/St. Joe ${ }^{123}$. Tratou-se de um substancial esquema de uso indevido de informações privilegiadas ${ }^{124}$ envolvendo a compra de ações e opções da empresa St. Joe Minerals, negociada no mercado acionário norte-americano. Um dia antes de uma oferta da Seagram pela St. Joe, operando a partir de contas do Banca Della Svizzera Italiana (BSI), corretores entraram massivamente no mercado e adquiriram 3.000 ações e opções sobre mais de 100.000 ações. Dados os indícios de fraude, a autoridade regulatória dos Estados Unidos ${ }^{125}$ iniciou procedimentos investigatórios regulares e tentou obter o congelamento dos proventos do negócio junto ao executor da ordem, a empresa Irving Trust. Todavia, a SEC não sabia a identidade dos investidores e o BSI se recusou a revelá-las alegando as leis de sigilo da Suíça, seu país-sede. O

\footnotetext{
${ }^{122}$ Vide supra. Vide também (Kaminsky and Schmukler 2002).

123 SEC v. Banca Della Svizzera Italiana and Certain Purchasers of Call Options for the Common Stock of St. Joe Minerals Corp. (“BSI/St. Joe”), 92 FRD 111 (SDNY1981).

${ }^{124}$ No jargão, insider trading.

${ }^{125}$ SEC - Securities and Exchange Commission [doravante SEC]
} 
processo tornou-se uma explosiva ameaça à confiabilidade do mercado norte-americano: caso a impunidade permanecesse, restaria reconhecido que a SEC não teria controle sobre uma grande parcela dos investidores, os estrangeiros. Com isso, manipulações poderiam acontecer em grande escala, prejudicando milhares de poupadores. $\mathrm{O}$ caso durou meses nos tribunais, e, ao final, o BSI informou à SEC que seu cliente era um italiano operando a partir de uma empresa de investimentos da Suíça. Os norte-americanos conseguiram reaver parte dos proventos da venda fraudulenta.

Casos assim podem prejudicar em muito a confiabilidade dos mercados em vista do vulto e da potencial lesividade. A repressão e persecução têm que ser céleres, eficientes e efetivas. Para contornar os problemas gerados pela abertura dos mercados acionários norte-americanos aos investidores estrangeiros, a SEC tratou de buscar soluções. A primeira tentada foi a utilização da Convenção de Haia Sobre Cooperação Judiciária em Matéria Civil ou Comercial ${ }^{126}$, de 1970. Tal caminho enfrentou diversos percalços: em primeiro lugar, não eram muitos os países signatários. Em segundo, seu mecanismo, baseado em cartas rogatórias, uso de funcionários consulares e comissários privados, tornava muito longa a tramitação de qualquer pedido de informação. Em terceiro o procedimento garantia pouco controle sobre a qualidade da diligência solicitada. Muitas vezes as informações solicitadas eram muito específicas ou especializadas, e o uso da justiça comum prejudicava os resultados.

A segunda tentativa foi a utilização de tratados bilaterais de cooperação chamados Tratados de Mútua Assistência Legal ${ }^{127}$. Tais tratados, todavia, são geralmente celebrados dentro de um contexto amplo de cooperação judiciária entre promotores, tribunais e Ministérios da Justiça, o que os faz também demasiado amplos. O primeiro tratado entre a Suíça e os Estados Unidos, por exemplo, havia entrado em vigor em $1977^{128}$. Tentou-se usá-lo no segundo caso internacional de grande repercussão, Santa

\footnotetext{
${ }^{126}$ Hague Convention on the Taking of Evidence Abroad in Civil or Commercial Matters, aberta para assinaturas em 18 de maio de 1970, 847 U.N.T.S. 231 [doravante Convenção de Haia].

${ }^{127}$ MLATs - Mutual Legal Assistance Treaties [doravante MLATs].

${ }^{128}$ Treaty Between the United States of America and the Swiss Confederation on Mutual Assistance in Criminal Matters, U.S.-Switz., May 25, 1977, 20 U.S.T. 2019.
} 
$\mathrm{Fe}^{129}$, ocorrido em 1981. Somente em 1986 a SEC conseguiu obter as medidas judiciárias buscadas.

A terceira tentativa, todavia, tornou-se a base de uma grande modificação na estrutura da cooperação internacional em matéria de valores mobiliários. Em 1982 a SEC e o governo suíço celebraram um Memorando de Entendimentos sobre intercâmbio de informacões ${ }^{130}$. Porque insider trading não era crime na Suíça, o mecanismo também incluía um acordo privado entre a SEC e a Associação Suíça dos Banqueiros. A iniciativa simplificou os procedimentos de investigação, e passou a ser utilizada em outros contextos. Nos anos seguintes, a SEC celebrou quase $50 \mathrm{MoUs}$ com autoridades de mais de 20 países ${ }^{131}$, formando uma densa malha jurídica de cooperação bilateral.

Na seqüência, os norte-americanos utilizaram essa teia de acordos como alavanca para a formação de um acordo multilateral de cooperação. Já em novembro de 1986, a questão foi levada à Organização Internacional de Comissões de Valores Mobiliários ${ }^{132}$, e uma foi aprovada uma resolução urgindo que um regime de assistência recíproca entre reguladores fosse criado ${ }^{133}$. Outras resoluções foram aprovadas em 1989 e $1994^{134}$. Grandes esforços foram feitos para ampliar a abrangência dessa cooperação. Em 1991, os membros da IOSCO adotaram o documento Princípios sobre Memoranda de Entendimento $^{135}$, que detalha melhores práticas a serem utilizadas na confecção de acordos bilaterais. Em 1997, uma nova resolução foi aprovada, apoiando a coleta de informação e manutenção de registros. Essa resolução foi incorporada no documento de

\footnotetext{
${ }^{129}$ SEC v. Certain Unknown Purchasers of the Common Stock of, and Call Options for the Common Stock of, Santa Fe Intl. Corp. (“Santa Fe”), [1983-1984 Transfer Binder] FedSecurLRptr (CCH) 99,424 (SDNY1983).

${ }^{130}$ Memorandum of Understanding concerning the exchange of information between the Government of the United States of America and the Government of Switzerland. [doravante MoU US-Switzerland] .Vide (Government of the United States of America and Government of Switzerland 1982).

${ }^{131}$ Segundo a SEC, foram assinados MoUs em matéria de cooperação investigativa com Alemanha (novembro de 1993; março de 1994; outubro de 1997), Argentina (dezembro de 1991), Austrália (outubro de 1993), Brasil (julho de 1988), Canadá (janeiro de 1988), Chile (junho de 1993), Espanha (julho de 1992), França (dezembro de 1989), Hong Kong (outubro de1995), Israel (fevereiro de 1996), Itália (maio de 1993), Japão (maio de 1986; maio de 2002; janeiro de 2006), Jersey (maio de 2002), México (outubro de 1990), Noruega (setembro de 1991), Países Baixo (dezembro de 1989; julho de 1992), Portugal (outubro de 1997), Reino Unido (setembro de 1986, setembro de 1991), Suíça (agosto de 1982; novembro de 1987; novembro de 1993), Singapura (maio de 2000). Vide http://www.sec.gov/about/offices/oia/oia_cooparrangements.htm.

${ }_{132}$ IOSCO - International Organization of Securities Commissions. [doravante IOSCO].

${ }^{133}$ Vide (Mann and Barry 2005).

${ }^{134}$ Vide (International Organization of Securities Commissions 1994).

${ }^{135}$ Vide (International Organization of Securities Commissions 1991).
} 
princípios da IOSCO, publicado em $1998^{136}$. Outra resolução a ser mencionada é a Resolução sobre Princípios para Manutenção de Registros, Coleta de Informações, e Poderes para a Aplicação da Legislação de Valores Mobiliários e Futuros ${ }^{137}$.

Em 2001 iniciaram-se negociações para um projeto mais ambicioso: o Memorando de Entendimento Multilateral da $\mathrm{IOSCO}^{138}$. O MoU IOSCO tem duas seções principais: (i) especificação dos tipos particulares de informação que deve ser compartilhada (identidade de clientes, registros de atividade negocial, informação de investigações); (ii) provisões de confidencialidade e sigilo (a informação pode ser utilizada em investigações e processos administrativos e penais, em cumprimento a determinações legais, mas não pode ser divulgada para outros fins). Até o momento, 63 autoridades adotaram-no e outras 29 assinaram o chamado "Apêndice B" - o procedimento inicial para aceitar o Memorando.

\section{II.2.4.2. Objetivos do processo de integração e papéis reservados para as instituições financeiras domésticas e estrangeiras.}

Três objetivos para esse processo de integração podem ser identificados: (i) coibir fraudes e outras práticas ilícitas afetando investidores domésticos, (ii) disciplinar instituições financeiras domésticas e estrangeiras, recuperando ativos e ressarcindo vitimas, (iii) desenvolver o mercado de capitais doméstico, melhorando sua credibilidade, aumentando sua profundidade, e atraindo investidores estrangeiros.

\section{III.2.4.2.1. Coibir fraudes e outras práticas ilícitas afetando investidores domésticos.}

O primeiro objetivo que pode ser encontrado no relato acima é aumentar o potencial preventivo das ações de autoridades domésticas em relação ao policiamento dos mercados de capitais nacionais. Com o aumento de fluxos transfronteiriços de investimentos, potenciais lacunas apareceram. Principalmente em relação aos Estados Unidos, principal mercado de capitais mundial, problemas de jurisdição administrativa e criminal tornaram-se explosivos, e se não fossem resolvidos, implicariam grandes danos à reputação e segurança das transações de valores mobiliários.

\footnotetext{
${ }^{136}$ Vide (International Organization of Securities Commissions 1994).

${ }^{137}$ Vide (International Organization of Securities Commissions 1998b).

${ }^{138}$ Vide (International Organization of Securities Commissions 2002) [doravante MoU IOSCO]
} 
Nessa perspectiva, ao conseguir de governos estrangeiros a assinatura de acordos de cooperação que se mostraram bastante efetivos, os governos interessados (em especial o governo norte-americano) agiram para resolver dois problemas principais. Em primeiro lugar, conseguiram formas de garantir a rápida investigação e produção de provas contra fraudadores, o que per se ajudaria a pacificar outros investidores locais e retomar a confiança perdida. Em segundo, pavimentaram o caminho para que investidores estrangeiros sérios passassem a cruzar com mais freqüências as fronteiras nacionais e o fluxo internacional de capitais aumentasse. Isso porque, ao ampliar o alcance das jurisdições de níveis de qualidade mais altos, uma verdadeira competição entre mercados capitais pôde começar a ser gestada. Aos maiores investidores e instituições financeiras ao redor do globo, então, foi reservado o papel de promover a competição internacional entre mercados de capitais, buscando melhores praças de negócios com maior avidez, e pressionando reguladores, autoridades e bolsas de valores a melhorarem. Às instituições financeiras intermediadoras de negócios foi incumbido o papel de conhecer clientes e suas operações internacionais, assumindo sua responsabilidade de prevenir negócios escusos ou limítrofes.

\section{II.2.4.2.2. Disciplinar instituições financeiras domésticas e estrangeiras.}

O segundo objetivo encontrado no relato acima foi o de permitir a punição efetiva e célere de fraudadores internacionais que anteriormente se escudavam sob o manto de complexas relações inter-jurisdicionais e burocráticos tratados de cooperação judiciária. Com isso, o compartilhamento de informações sigilosas entre autoridades tornou-se mais rotineiro, por um lado, e a recuperação de ativos e coleta de indenizações por danos causados, por outro lado, tornou-se mais célere.

Nessa perspectiva, interessava aos governos nacionais a criação de uma efetiva rede internacional de cooperação entre autoridades administrativas e judiciárias que permitisse atividades repressivas a fraudes de alcance transnacional. Destarte, os governos nacionais participantes desejavam criar mecanismos para permitir que investidores locais e estrangeiros ativamente persigam suas pretensões punitivas e satisfaçam suas necessidades de ressarcimento. Aos investidores internacionais, portanto, foi reservado o papel de ativamente participar na investigação de fraudes internacionais, agora em investigações e processos de natureza transfronteiriça. Em vista da estrutura 
jurídica posta em funcionamento, o sistema adversarial, litigioso e desconcentrado foi preservado, e a recuperação de ativos com indenização de investidores lesados foram mantidos como pedra fundamental do sistema.

III.2.4.2.3. Desenvolver o mercado de capitais doméstico e instituições regulatórias, melhorando sua credibilidade, profundidade e integridade.

O terceiro objetivo que pode ser depreendido do relato é auxiliar no desenvolvimento do mercado de capitais doméstico, principalmente nos casos dos países em desenvolvimento que assinaram o Memorando de Entendimentos Multilateral. Ao promover a cooperação internacional de forma multilateral, a estrutura jurídica criada proporcionou o compartilhamento de informações e coordenação de ações, por um lado, e, por outro, o aprendizado institucional e a redução de custos para reguladores com pouca experiência, por outro.

Nessa perspectiva, autoridades regulatórias mais jovens beneficiam-se ao participar de interações assimétricas envolvendo autoridades nacionais possuidoras de maior experiência. Além disso, caso fraudes envolvendo jurisdições jovens e experientes ocorram, o intercâmbio e a coordenação poderiam baixar os custos das investigações. Outrossim, essa interação mais próxima gera padronização de procedimentos e expediência nas investigações. Com mais agências trabalhando de forma parecida, a segurança jurídica e institucional aumenta, e investidores internacionais têm seus custos reduzidos também porque passam a existir ganhos de escala e escopo. Estar inserido em tais redes de cooperação, por fim, importa ganhos de reputação e de qualidade institucional. Encontra-se, portanto, um papel relevante para investidores e instituições financeiras internacionais: pressionar por mudanças, pela construção de instituições mais efetivas, e pela modernização dos procedimentos. Por outro lado, investidores e instituições locais passam a poder desfrutar de mercados estrangeiros, o que reduz os custos de captação, aumenta os ganhos de dispersão de risco, e faz crescer a sofisticação do mercado. 


\section{II.2.5. ACORDO SOBRE SERVIÇOS FINANCEIROS NA OMC: INTEGRAÇÃO VIA COMÉRCIO INTERNACIONAL.}

O Acordo Sobre Serviços Financeiros da OMC tem natureza multilateral e estrutura jurídica complexa. Foi produto de mais de uma década de negociações e inserese num contexto mais amplo Além de envolver dezenas de países, trata-se de um processo de integração assimétrico, em que diversos interesses e objetivos tiveram de ser compatibilizados. Trata-se, outrossim, de acordo com grande impacto na arquitetura financeira global.

\section{II.2.5.1. Histórico do processo de integração.}

O Acordo sobre Serviços Financeiros da OMC foi finalizado em 13 de dezembro de $1997^{139}$. Trata-se de um dos mais complexos e abrangentes acordos sobre serviços financeiros da história: 102 países negociaram durante mais de 5 anos compromissos de liberalização do comércio de serviços financeiros. Além disso, é pontuado por peculiaridades. Em primeiro lugar, é um dos subprodutos da Rodada Uruguai de negociações comerciais internacionais. Isso implica estar inserido dentro do contexto do Acordo Geral sobre Comércio de Serviços ${ }^{140}$, de sua dinâmica política, e quadro jurídico $^{141}$. Em segundo lugar, todavia, trata-se de um acordo sui generis dentro da dinâmica do GATS: foi finalizado três anos depois da Rodada ter sido concluída, o que indica certa autonomia em sua dinâmica política; possui uma moldura jurídica própria, idealizada especificamente para negociações de serviços financeiros, que o diferencia juridicamente dos outros setores de serviços.

Apesar da Rodada Uruguai ter sido lançada em 1986 em Punta del Este, foi somente em 1991 que progressos substanciais foram conseguidos na área de serviços: até então o que se havia conseguido eram definições conceituais. De outro modo dito, foram necessários 5 anos para chegar a soluções sobre como aplicar os conceitos desenvolvidos durante os mais de 40 anos da prática do Acordo Geral de Comércio e Tarifas ${ }^{142}$. Classicamente, acordos de comércio internacional apóiam-se em dois princípios

\footnotetext{
${ }^{139}$ FSA - Financial Services Agreement, também chamado de Quinto Protocolo ao GATS. [doravante FSA ou Quinto Protocolo]. Vide (Committee on Trade in Financial Services 1997; World Trade Organization 1997).

${ }^{140}$ GATS - General Agreement on Trade in Services [doravante GATS]. Vide (World Trade Organization 1994).

${ }^{141}$ Sobre aspectos do quadro jurídico do GATS, vide infra.

${ }^{142}$ GATT - General Agreement on Trade and Tariffs [doravante GATT].
} 
fundamentais: não-discriminação e reciprocidade. Abaixo, eles serão explicados com maior detalhe. No momento é suficiente dizer que, no GATT, governos nacionais recorrem a ambos princípios para barganhar concessões comerciais, tentando assim obter maior acesso a mercados estrangeiros para seus produtores nacionais.

Em relação a serviços financeiros, alguns governos convenceram-se que a Rodada Uruguai poderia ser utilizada para conseguir a garantia de maior acesso a mercado e menos discriminação para suas instituições financeiras. Os Estados Unidos e certos países das Comunidades Européias e da Europa ${ }^{143}$ foram os países que apoiaram com maior intensidade a idéia de adaptar a moldura do GATT para negociações sobre serviços. Empresas como Citibank, American Express, AIG, Lloyds, e SwissRe tiveram papel importante no convencimento de seus respectivos governos ${ }^{144}$. Diversos estudos técnicos foram contratados, debates intermináveis ocorreram entre diplomatas, e grande pressão política foi feita ${ }^{145}$. Em julho de 1990 uma minuta de acordo-quadro, feito nos moldes do GATT, todavia adaptado às particularidades das negociações sobre serviços, ficou pronta. Esse texto daria origem ao GATS.

Baseado nesse conjunto de regras, as negociações setoriais começaram a progredir. Os principais alvos eram países asiáticos e mercados emergentes. Em particular, os Estados Unidos tinham grande preocupação em utilizar a pressão multilateral para dobrar o Japão, fazendo o país abrir mais seus mercados financeiros à concorrência internacional. Como isca, os EUA colocaram na mesa de negociações uma significativa sua proposta sobre serviços financeiros .

Em 1991, todavia, decidiram-se por retirar retirá-la em vista da insatisfação com a contrapartida recebida: o nível de abertura proposto para os setores bancário e mercado de capitais não foi aceito pelos EUA ${ }^{146}$. Com o abrupto fechamento da Rodada Uruguai que aconteceu em 15 de dezembro de 1993, precipitado pelo término da autoridade negociadora dada pelo Congresso americano ao Presidente Clinton ${ }^{147}$ - tal impasse não foi solucionado. Dado que o consenso não foi alcançado, EUA e CEs patrocinaram um

\footnotetext{
${ }^{143}$ Vide (Mirandola 2006, 143-163; Drake and Nicolaidis 1992).

${ }^{144}$ Vide (Drake and Nicolaidis 1992).

145 Vide (Jones and Ruane 1990; Griffiths 1975; Feketekuty 1988; Djajic and Kierzkowski 1995; Casas 1983; van Marrewijk, Stibora, and de Vaal 1996; Mirandola 2006)..

${ }^{146}$ Vide (Drake and Nicolaidis 1992).

147 Trata-se da chamada Fast-track Negotiating Authority. Vide (U.S. International Trade Commission 1993).
} 
uma solução híbrida que foi aceita pelos Ministros e negociadores na conclusão da Rodada em Marraqueche. As negociações sobre serviços seriam encerradas e as listas de compromissos fariam parte do Ato Único ${ }^{148}$ que incorporava todos os resultados da Rodada Uruguai. No entanto, em setores específicos (serviços financeiros incluso) e com mandatos especiais, negociações continuariam. Em outras palavras, a Rodada Uruguai terminou, mas o imbróglio do Acordo sobre Serviços Financeiros continuou.

No pós-Marraqueche, o primeiro grande impasse a ser resolvido tinha como personagens principais os Estados Unidos e o Japão. Norte-americanos viam-se prejudicados sensivelmente no setor de seguros no que tange o tratamento nacional e a obtenção de efetivas condições de competir no mercado japonês. Para resolver tal problema, ambos os países entraram em negociações bilaterais e, em setembro/outubro de 1994, foi acordada uma Moldura para a Nova Parceria Econômica EUA-Japão relativa a medidas no setor de seguros ${ }^{149}$. Tal acerto envolvia medidas em cinco áreas diferentes: (i) transparência e proteções administrativas para seguradoras estrangeiras; (ii) medidas de desregulamentação do mercado de seguros; (iii) empresas estatais de seguros; (iv) medidas relativas à competição; (v) consultas e implementação das medidas. Em 13 de fevereiro de 1995 tal moldura foi transformada num acordo bilateral.

Com as divergências entre os dois grandes parceiros parecendo reduzir-se, outros países sentiram-se seguros para colocar propostas de liberalização financeira sobre a mesa de negociação. Até 7 de junho de 1995 dezesseis países haviam submetido listas de compromissos revisadas ${ }^{150}$. Além disso, mais oito países haviam submetido indicações de suas futuras listas ${ }^{151}$. Entretanto, na penúltima ${ }^{152}$ reunião antes do vencimento do prazo final, uma grande reviravolta ocorreu. Argumentando que diversos países, incluindo países em desenvolvimento, estariam "pegando carona" (free riding) nas suas ofertas, os Estados Unidos anunciaram duas decisões. A primeira foi a de manter na mesa uma

\footnotetext{
${ }^{148} \mathrm{Na}$ expressão original em inglês, single undertaking.

${ }^{149}$ Vide (Interim Group on Financial Services 1994).

${ }^{150}$ São eles: África do Sul, Austrália, Brasil, Canadá, Colômbia, Comunidades Européias, Coréia, Estados Unidos, Hong Kong, Japão, México, Marrocos, Nova Zelândia, Noruega, República Dominicana e Suíça. Vide (World Trade Organization, Council on Trade in Services, Committee on Trade in Financial Services 1995a).

${ }^{151}$ São eles: Chile, Polônia, Romênia, Singapura, República Eslovaca, República Tcheca, Turquia e Venezuela.

${ }^{152}$ Vide (World Trade Organization, Council on Trade in Services, Committee on Trade in Financial Services 1995b).
} 
oferta que protegesse as atividades dos prestadores financeiros instalados no território nacional; e a segunda foi não tornar vinculante sua oferta feita, e não aplicar o tratamento nacional a novos entrantes. Os Estados Unidos decidiram, na prática, retirar suas ofertas nos setores de serviços bancários, valores mobiliários, seguro, gerenciamento de fundos, e outros produtos financeiros.

Tal atitude foi recriminada pelas Comunidades Européias, Japão, Austrália, Suíça, Hong Kong, Suíça, Nova Zelândia, Canadá, e Noruega, gerando muita discórdia e debate. A reunião subseqüente ${ }^{153}$, que tinha sido agendada para o dia seguinte, começou tensa. Sem acordo em vista, decidiu-se por assegurar o progresso conseguido e protelar decisões mais drásticas até os ânimos esfriarem: aprovou-se decisão que congelou as ofertas feitas e adiou quaisquer decisões até dia 28 de julho de $1995^{154}$. Quase um mês passou-se e, em 21 de julho de $1995^{155}$, as Comunidades Européias propuseram que os Membros mantivessem suas melhores propostas, submissões escritas e indicações feitas bilateralmente, na forma de compromissos multilaterais na base MFN que vigeriam por um tempo determinado (até 31 de dezembro de 1997). Seria um acordo, portanto, entre todos os membros que haviam submetido ofertas à exceção dos Estados Unidos. Essa proposta causou bastante discussão, mas dela nasceu um consenso que se materializou no "Segundo Protocolo ao GATS". O Protocolo passou a ser chamado "Acordo Interino". No cômputo final, 29 Membros (as Comunidades Européias contando apenas como um) submeteram listas de compromisso revisadas para serem anexadas ao Segundo Protocolo $^{156}$. Além disso, 13 membros submeteram listas de exceções MFN revisadas ${ }^{157}$. Tais Membros comprometeram-se a enviar o referido Segundo Protocolo à ratificação para que o acordo entrasse em vigor em 20 de junho de 1996.

\footnotetext{
${ }^{153}$ Vide (World Trade Organization, Council on Trade in Services, Committee on Trade in Financial Services 1995c)

${ }^{154}$ Vide (World Trade Organization, Council on Trade in Services 1995)

${ }^{155}$ Vide (World Trade Organization, Council on Trade in Services, Committee on Trade in Financial Services $1995 \mathrm{~d})$.

${ }^{156}$ Os países foram: Austrália, Brasil, Canadá, Chile, República Tcheca, República Dominicana, Egito, Comunidades Européias, Hong Kong, Hungria, Índia, Indonésia, Japão, Coréia, Kuwait, Malásia, México, Marrocos, Noruega, Paquistão, Filipinas, Polônia, Singapura, República Eslovaca, África do Sul, Suíça, Tailândia, Turquia, e Venezuela.

${ }^{157}$ Os países foram: Canadá, República Tcheca, Hong Kong, Indonésia, Coréia, Malásia, Filipinas, Singapura, República Eslovaca, Suíça, Tailândia, Turquia e Venezuela.
} 
Com a aceitação do "Acordo Interino", na prática, os países ganharam um prazo de dois anos para continuar as negociações sobre serviços financeiros. A vigência do "Acordo Interino", em conseqüência, funcionava como uma ameaça crível de que as negociações deveriam acabar até o final do prazo estabelecido. $\mathrm{O}$ assunto tornou-se, entretanto, morno. Foi só na Conferência Ministerial de Singapura de dezembro de 1996 que reviveu: determinou-se que as conversações fossem retomadas em abril de 1997. A Declaração Ministerial registrou que os membros se comprometeriam a alcançar "melhorias nos compromissos sobre acesso a mercado, com um nível de participação mais amplo"158. Além disso, com o prazo acertado na Segunda Decisão sobre Serviços Financeiros, os países teriam sessenta dias entre $1^{\circ}$ de novembro de 1997 e 30 de dezembro do mesmo ano para poder modificar ou retirar compromissos de suas listas, e arrolar exceções ao tratamento MFN.

Em 10 de abril o negociadores reuniram-se novamente e deram partida ao processo de negociação ${ }^{159}$. Discutiu-se um cronograma que previa compactos de negociações em junho, julho, setembro, outubro, novembro e dezembro. A fórmula decidida incluía sempre a realização de reuniões bilaterais e uma sessão multilateral de conversas. Entretanto, até 18 de setembro apenas 19 ofertas de acesso a mercado estavam sobre a mesa de negociações ${ }^{160}$.

Foi a crise asiática que mudou o panorama negocial. Quando irrompeu, trouxe certa incerteza. Membros desenvolvidos, no entanto, manifestaram-se afirmando que a oportunidade deveria ser utilizada para que países em desenvolvimento enviassem sinais de seu compromisso com a estabilidade dos mercados para investidores estrangeiros. Em vista da sensibilidade dos países em desenvolvimento às condições internacionais, Estados Unidos e Comunidades Européias passaram a fazer pressão no sentido de se aumentar o nível de compromissos dos países. Na reunião de 17 de outubro ${ }^{161}$, por exemplo, as Comunidades pronunciaram-se reiterando que o objetivo das negociações, em sua opinião, seria não apenas consolidar o presente grau de abertura comercial, mas,

\footnotetext{
158 (World Trade Organization 1996).

${ }^{159}$ (World Trade Organization, Council on Trade in Services, Committee on Trade in Financial Services 1997a).

${ }^{160}$ (Multilateral Trade Negotiations, Trade Negotiations on Services 1991).

161 (World Trade Organization, Council on Trade in Services, Committee on Trade in Financial Services 1997b).
} 
também, criar bases para mais comércio e investimento. Sua indústria financeira estava interessada em investir no estrangeiro, mas somente quando houvesse um ambiente previsível para investimento e operação nos países hóspedes. Os Estados Unidos confirmaram que desejavam melhorias substanciais que garantissem o direito de estabelecimento, permitissem controle estrangeiro majoritário, tratamento nacional, e que mantivessem os direitos existentes de prestadores estrangeiros em diversos subsetores. Por fim, conforme previsto, as minutas das decisões e do Protocolo que incorporaria os compromissos dos países sobre serviços financeiros circulou para avaliações.

O número de ofertas submetidas na reunião seguinte ${ }^{162}$ subiu bastante, passando a trinta e duas. A principal questão, no entanto, foi a discussão sobre as Minutas de Protocolo e das duas Decisões que o acompanhariam. Foi definido que o prazo final para a aceitação do acordo deveria ser 29 de janeiro de 1999. Posteriormente esse prazo foi postergado para $1^{\circ}$ de março do mesmo ano. Foi constatada, outrossim, a necessidade de se realizar uma reunião antecedendo a reunião final.

Em 8 de dezembro de 1997 o número de ofertas tinha subido para 45 e outras ainda estavam por $\operatorname{vir}^{163}$. Cinco dias para o encontro final ainda restavam e alguns pontos que deveriam ser fechados em reuniões bilaterais para que o acordo geral acontecesse. $\mathrm{O}$ clima das negociações, no entanto, era positivo e mesmo os Estados Unidos apresentaram uma oferta melhorada. Esse clima favorável foi refletido na reunião de 12 de dezembro $^{164}$, programada para concluir as negociações sobre serviços financeiros. No total, 56 ofertas representando 70 membros foram submetidas. Os Estados Unidos pronunciaram-se registrando que o pacote resultante era impressionante em vista de sua abrangência: cobria mais de $95 \%$ do total do comércio de serviços financeiros, representando US\$ 17 trilhões de dólares em ativos em valores mobiliários, US\$ 38 trilhões em empréstimos bancários, e US\$ 22.2 trilhões em prêmios de seguros. O acordo

\footnotetext{
${ }^{162}$ (World Trade Organization, Council on Trade in Services, Committee on Trade in Financial Services 1997c)2/11/10 5:15 PM2/11/10 5:15 PM.

${ }^{163}$ Vide (World Trade Organization, Council on Trade in Services, Committee on Trade in Financial Services 1997d).

${ }^{164}$ Vide (World Trade Organization, Council on Trade in Services, Committee on Trade in Financial Services 1997e).
} 
assinado foi nomeado "Quinto Protocolo ao GATS", também conhecido como "Acordo sobre Serviços Financeiros - FSA"165.

Foi decidido que o FSA se aplicaria apenas aos países que expressamente o aceitassem, o que não impediu que outros países apresentassem ofertas no setor de serviços diferentes das constantes do FSA. Na data de entrada em vigor do FSA $-1^{\circ}$ de março de 1999 - , os 52 membros que completaram os procedimentos de implementação domésticas decidiram que o protocolo permaneceria aberto para novas adesões até 15 de junho de 1999. Com isso, no total, 102 membros comprometeram-se com a liberalização do setor financeiro ${ }^{166}$ : em relação às tratativas da Rodada Uruguai, 70 países melhoraram suas ofertas iniciais e 32 mantiveram as concessões feitas. Os EUA retiraram suas exceções ao tratamento MFN aos setores bancário e mercado de capitais mas, em larga medida retaliando a Malásia por políticas que afetaram as seguradoras Aetna e AIG, exerceram a exceção do Artigo II em relação ao setor de seguros.

\section{II.2.5.3. Objetivos do processo de integração e papéis reservados para as instituições financeiras domésticas e estrangeiras.}

Acordos multilaterais tão complexos, produtos de longas e aprofundadas negociações, só se tornam possíveis porque, de algum modo, incorporaram interesses e preocupações bastante diversas, e, não freqüentemente, contraditórias. A existência de consenso sobre o acordo implica que diversos objetivos foram contemplados. A partir do relato acima, podem-se identificar, portanto, ao menos três objetivos bastante heterogêneos para que governos nacionais embarcassem no processo de integração financeira via abertura comercial: (i) reduzir barreiras para o fluxo de capitais e conseguir maior acesso a mercados estrangeiros; (ii) expor instituições financeiras domésticas à competição estrangeira e incorporar tecnologia estrangeira; (iii) receber investimentos externos, recapitalizar bancos domésticos com problemas, e melhorar a credibilidade do sistema financeiro doméstico diante de investidores estrangeiros;

\footnotetext{
${ }^{165}$ Na sigla em inglês, FSA - Financial Services Agreement. Para evitar confusão com o "Acordo", será mantida a terminologia FSA para referências. Sobre o FSA, vide infra.

${ }^{166}$ Vide (Dobson and Jacquet 1998).
} 
II.2.5.2.1. Reduzir barreiras para fluxos de capitais e operação transfronteiriça de instituições financeiras, conseguir maior acesso a mercados estrangeiros para instituições financeiras domésticas.

O primeiro objetivo que pode ser encontrado no relato sobre o processo de integração financeira via acordo comercial na $\mathrm{OMC}$ é a redução de barreiras à operação das grandes multinacionais financeiras internacionais. Tema caro principalmente para os países-sede dos maiores bancos internacionais, a remoção de obstáculos para a operação transfronteiriça de instituições financeiras envolve a liberalização de fluxos de capitais, proteção de investimento estrangeiro em território nacional, remoção de barreiras discriminatórias, e modificações regulatórias. Tais problemas são mais caros a países com aproximadamente o mesmo nível de sofisticação bancária, o que implica a discussão de um processo de abertura financeira mais homogêneo.

Nessa perspectiva, ao utilizar a estrutura jurídica do GATS para negociar reformas regulatórias, governos nacionais pretendem resolver dois problemas principais. O primeiro é um problema de ação coletiva e barganha: quando a abertura comercial é assimétrica e unilateral, países têm incentivos a serem protecionistas porque o último a liberalizar ganha mais. Um segundo é um problema de coordenação. Abertura financeira demanda reformas regulatórias simultâneas em diversos países, e um grande esforço doméstico dos respectivos governos. Para otimizar esse esforço e potencializar a integração, é interessante que sejam adotados, na medida do possível, padrões e regras comuns. Em tal quadro, reserva-se um papel essencial aos bancos multinacionais. Em primeiro lugar, espera-se que pressionem os governos de seu país-sede e dos países de suas filiais, impulsionando-os às negociações. Em segundo, tem-se que eles podem funcionar como fiéis da balança, calibrando a distribuição de vantagens por meio de arbitragem. Reduzem, assim, o benefício do retardatário protecionista, criando incentivos para movimentos conjuntos. Em terceiro, estruturas transfronteiriças tem papel relevante na coleta e disseminação de informações sobre diferenças regulatórias e institucionais. Como são organizações unitárias que operam em mais de uma jurisdição, podem oferecer insumos únicos para que sejam estabelecidos regimes regulatórios compatíveis. Aos bancos locais, governos nacionais podem genericamente reservar o papel de contraponto ao poder de arbitragem dos bancos transnacionais. Esse ponto ficou patente no imbróglio envolvendo Estados Unidos, Japão e outros países asiáticos, em relação aos setores de 
seguros e mercado de capitais. A pressão de instituições domésticas impulsionou os asiáticos a manterem posições bastante protecionistas. Foi necessário que os países chegassem antes a um acordo bilateral para destravar as negociações multilaterais.

II.2.5.2.2. Expor instituições financeiras domésticas à competição estrangeira, incorporar melhores práticas e tecnologia bancária.

O segundo objetivo que pode ser depreendido do relato acima é expor instituições financeiras nacionais à competição estrangeira e incentivar a modernização bancária da indústria nacional. No ambiente das discussões da integração apoiada no GATS, tal tema surge principalmente relacionado a projetos de modernização em mercados emergentes. A idéia subjacente é utilizar a entrada de bancos estrangeiros para aplicar um choque competitivo no setor financeiro doméstico, provocando mudanças estruturais.

Nessa perspectiva, interessava aos governos nacionais criar um desenho institucional que permitisse a entrada controlada de instituições financeiras estrangeiras, de modo a otimizar três elementos principais: (i) o acesso a capitais internacionais e investidores; (ii) o acesso a tecnologia, novos produtos e know how operacional estrangeiro; (iii) maior competição, juros mais baixos, mais diversidade, maior profundidade e completude nos mercados. Diversas estruturas jurídicas foram utilizadas, criando múltiplas formas de relacionamento entre instituições nacionais e estrangeiras. Houve países, por exemplo, que recorreram à $\mathrm{OMC}$ para chancelar seus programas de privatização de bancos públicos (Brasil e México) e de joint ventures e parcerias entre instituições domésticas e globais (Malásia). Nesses casos, o papel das instituições internacionais era o de investir, aportando capital, de trazer tecnologia administrativa, e de criar novos produtos, estabelecendo-se firmemente em território nacional, e operando por conta própria ou em conjunto com sócio controlador. Já o papel das instituições domésticas era facilitar a transição entre o antigo controlador (nacional) e o novo (nacional+estrangeiro), transmitir conhecimentos do ambiente institucional, e suavizar o relacionamento entre autoridades nacionais e estrangeiras. Outros países recorreram às negociações da OMC para sinalizar que desejavam firmar parcerias estratégicas com investidores internacionais sem, no entanto, deixar que o controle de bancos nacionais fosse alienado a estrangeiros (China). $\mathrm{O}$ intuito dessa estratégia seria permitir maior transmissão de conhecimento, um prazo mais longo, e evitar a desnacionalização do 
setor. O papel das instituições estrangeiras seria, portanto, o de um ativo investidor minoritário. Nacionais deveriam manter-se na direção dos bancos, submetidos, no entanto, a uma melhor estrutura de governança.

II.2.5.2.3. Melhorar a credibilidade do sistema financeiro doméstico e restaurar a confiança de investidores estrangeiros, receber investimentos externos, e recapitalizar bancos domésticos.

O terceiro objetivo que pode ser depreendido do relato acima é auxiliar países atingidos pela seqüência de crises acontecida na segunda metade da década de 2000 a se recuperarem. Após os baques recebidos pelo México em 1995 e pela Malásia, Tailândia e outros países asiáticos, em 1997, os mercados financeiros internacionais sofreram com problemas de liquidez. Principalmente países em desenvolvimento tiveram seu acesso a investidores internacionais reduzido. As negociações na OMC foram, portanto, utilizadas como instrumento para reabrir e descongelar os fluxos de capitais para países em desenvolvimento.

Nessa perspectiva, ao assumir obrigações de acesso a mercado e nãodiscriminação no âmbito do Quinto Protocolo ao GATS, interessava aos governos nacionais dos mercados emergentes afetados sinalizar que ofereciam garantias extras aos investidores estrangeiros de que mais dinheiro não seria perdido, e que o governo não promoveria intervenções heterodoxas na economia apesar da crise. Além disso, a assunção de compromissos na OMC foi copulada à realização de outras reformas liberalizantes unilaterais, e à aceitação de obrigações junto a órgãos financeiros multilaterais como o FMI. Às instituições financeiras estrangeiras operando em território nacional foi reservado, portanto, o papel de investidores privilegiados, fontes de capital externo, e fiadores da estabilização. Em relação ao primeiro papel, o que se desejava era deixar claro que o capital estrangeiro investido estaria protegido contra expropriação do governo apesar do tumulto macroeconômico. Em relação ao segundo papel, tendo em vista que a situação de diversas outras instituições locais havia deteriorado, era necessário que se injetasse mais capital na economia, de modo a recuperá-las e evitar uma crise sistêmica. Em relação ao terceiro papel, a presença de bancos estrangeiros atuando em território nacional servia de âncora estabilizadora: a exposição de bancos estrangeiros a países emergentes em crise serviria para aumentar o interesse dos governos dos países- 
sede na situação das filiais estrangeiras de seus campeões. Com isso, socorro se tornaria mais provável.

\section{II.3. MOLDURA JURÍDICA DA INTERNACIONALIZAC C̃o DAS FINANCAS.}

\section{II.3.1. COMO INTEGRAR MERCADOS FINANCEIROS: ESTRUTURAS JURÍDICAS.}

\section{II.3.1.1. Instrumentos jurídicos: Generalidades.}

Apenas para os efeitos da presente tese, os processos de integração financeira que foram descritos acima serão classificados em cinco categorias, segundo sua natureza jurídica:

- Convergência, liberalização unilateral ou abdicação regulatória. Essa categoria se caracteriza justamente pela ausência de uma estrutura internacional stricto sensu dando suporte ao processo de integração. Implica a adoção unilateral de regimes regulatórios estrangeiros, eliminação unilateral de barreiras e regulamentos, ou, em casos mais radicais, supressão unilateral da própria capacidade regulatória, com delegação a autoridades estrangeiras ou internacionais. Geralmente baseado em mudanças regulatórias domésticas tal modalidade de integração pode envolver reformas estruturais profundas na moldura regulatória de um setor ou atividade econômica. Maiores explicações serão dadas quando da descrição da estrutura jurídica do processo de liberalização financeira unilateral brasileira da década de 1990.

- Acordos de reconhecimento. Estrutura jurídica de integração econômica que visa a estabelecer condições em que a outorga de direitos a um agente privado ou reconhecimento de um status jurídico por parte de um País $\mathrm{P}_{\mathrm{i}}$, terá validade e será respeitada no território do país $\mathrm{P}_{\mathrm{j}}$. Celebrado por dois ou mais países, geralmente é utilizado no contexto de autorizações e permissões concedidas pela autoridade do país $\mathrm{P}_{\mathrm{i}}$ a um determinado particular $p$. Se o país $\mathrm{P}_{\mathrm{j}}$ reconhecer autorizações concedidas por $\mathrm{P}_{\mathrm{i}}$, o particular $p$ poderá operar no território de $\mathrm{P}_{\mathrm{j}}$ sem solicitar nova autorização ao governo local, tendo como fundamento o acordo de reconhecimento (observadas, é 
claro, eventuais restrições incluídas no acordo). Maiores explicações serão dadas quando da descrição da estrutura jurídica do mercado financeiro único europeu.

- Acordos de harmonização. Estrutura jurídica de integração econômica que visa a estabelecer padrões e regras uniformes para a adoção de normas e regulamentos domésticos. Celebrados entre dois ou mais países, podem ter os mais diversos conteúdos: desde classificações harmonizadas de produtos até procedimentos padronizados, passando por requisitos mínimos homogêneos e regras de prestação de serviço. Maiores explicações serão dadas quando da descrição da estrutura jurídica do Acordo da Basiléia.

- $\quad$ Acordos de cooperação. A expressão será utilizada aqui de forma bastante estrita para identificar uma estrutura jurídica de integração econômica que visa a estabelecer procedimentos de colaboração entre autoridades executivas e agências reguladoras de dois ou mais países. Não necessitam ter a natureza de tratado internacional, podendo incluir meros acordos executivos - como, aliás, freqüentemente é o caso. Geralmente versam sobre intercâmbio de informações, confidencialidade, e execução de tarefas e procedimentos conjuntos.Maiores explicações serão dadas quando da descrição da estrutura jurídica do Memorando Multilateral de Entendimentos da IOSCO.

- Acordos comerciais. Estrutura jurídica de integração econômica das mais antigas, acordos comerciais visam a reduzir barreiras à importação e exportação de bens e serviços. Originalmente concebidos como tratados bilaterais de amizade entre nações, são caracterizados pela obediência a, ao menos, dois princípios essenciais: o de tratamento de nação mais favorecida ${ }^{167}$ e de reciprocidade. Hodiernamente são utilizados de formas bastante sofisticadas para incluir, além de comércio de bens e serviços, aspectos de investimentos, propriedade intelectual, concorrência e até regulação do trabalho, meio ambiente e compra governamentais. Maiores explicações serão dadas quando da descrição da estrutura jurídica do Acordo sobre Serviços Financeiros da OMC.

${ }^{167}$ MFN-Most Favoured Nation. 


\section{II.3.1.2. Estrutura jurídica liberalização unilateral brasileira.}

O processo de integração financeira brasileira é, por excelência, um caso de liberalização unilateral. $\mathrm{Na}$ forma descrita acima, implicou, em diversas dimensões, a adaptação a padrões internacionais, adoção unilateral de práticas regulatórias compartilhadas, compatibilização de estruturas de mercado, e remoção de barreiras à operação de instituições financeiras estrangeiras. Necessitou, portanto, um grande esforço de reforma institucional, com modificação da estrutura de órgãos regulatórios, aprovação de substanciais mudanças no conteúdo de leis e regulamentos internos.

Dois tipos de estratégias jurídicas foram intentadas. Em primeiro lugar está o que se pode chamar de convergência - a adoção unilateral de padrões e práticas internacionais. Normas brasileiras incorporaram conteúdos harmonizados, instituições nacionais foram adaptadas para mimetizar o funcionamento de instrumentos de intervenção necessários aos reguladores nacionais, mudanças tiveram de ser feitas na legislação e regulação para que boas práticas internacionais pudessem ser adotadas no pais. Em segundo lugar, barreiras à entrada de estrangeiros tiveram de ser removidas, e diversos segmentos de mercado tiveram de ser liberalizados, de modo a tornar o setor financeiro brasileiro mais atrativo a estrangeiros.

\section{II.3.2.2.1. Convergência e adoção de padrões e práticas internacionais.}

A convergência institucional ocorreu em dois níveis. Em primeiro lugar está o nível prudencial: adoção de padrões prudenciais vigentes internacionalmente. Como caso exemplar e central está a internalização do Acordo da Basiléia sobre requisitos de capital ${ }^{168}$ por meio da Resolução 2.099/94 do Conselho Monetário Nacional. A referida resolução estipulou prazos, regras de transição e procedimentos para que todas as instituições financeiras brasileiras abrangidas pelo Acordo da Basiléia se ajustassem.

Em segundo lugar está o nível institucional. A prática internacional sugere a criação de órgãos de supervisão que sejam independentes de pressão política (afinal, terão de tomar decisões difíceis que afetam interesses bastante organizados), estruturas de

\footnotetext{
${ }^{168}$ Sobre o Acordo da Basiléia, vide infra.
} 
prevenção a crises (que possam identificar problemas prontamente e intervir para corrigilos) e arranjos de salvamento e mitigação de danos (que permitam reduzir as perdas dos poupadores e preservar a higidez do sistema financeiro). Em relação ao insulamento, decidiu-se por modificar a composição do Conselho Monetário Nacional (CMN). O art. 8 da Medida Provisória 542 de $30.06 .1994^{169}$ alterou a Lei $n^{0} 4.595$ de 31.12.64 para manter apenas os Ministros da Fazenda e do Planejamento e o Presidente do Banco Central na composição do $\mathrm{CMN}$, excluindo outros $\operatorname{Ministros}^{170}$, presidentes de outros bancos públicos ${ }^{171}$, e membros da iniciativa privada.

Em relação às estruturas de prevenção à crise, duas foram as grandes mudanças. A primeira foi a criação de programas de empréstimos subsidiados e estímulo à reorganização do setor financeiro: o PROER, criado por meio da Medida Provisória 1.179, de 03.11.95 para abranger instituições privadas, e o PROES, criado por meio da Medida Provisória 1.514 de 05.09.96 para abranger instituições públicas. A segunda foi o fortalecimento dos instrumentos à disposição do Banco Central do Brasil, notadamente regimes de intervenção, liquidação extrajudicial, e regime de administração especial temporária (RAET). Interventores, liquidantes e diretores de RAET, com autorização do BC, passaram a ter o poder de transferir bens, direitos e obrigações, alienar ou ceder bens e direitos e acordar a assunção de obrigações, bem como proceder à constituição ou reorganização de sociedades.

Em relação aos arranjos de salvamento e mitigação de danos, a medida mais importante foi a autorização de criação do Fundo de Garantia de Créditos (FGC) (Resolução 2.127, de 31.08.95) e aprovação de seus estatuto e regulamento (Resolução 2.211, de 16.11.95). O mecanismo do FGC foi em grande parte baseado no Federal Deposit Insurance Corporation (FDIC) norte americano. Na adaptação brasileira, decidiu-se por criar uma associação civil sem fins lucrativos de prazo indeterminado de duração, sociedade de direito privado cujo objeto é dar cobertura a depósitos e aplicações nas hipóteses de decretação de intervenção, liquidação extrajudicial ou falência de instituição que participe do referido fundo, ou, ainda, de reconhecimento pelo $\mathrm{BCB}$, de estado de insolvência da instituição que, nos termos da legislação vigente, não esteja

\footnotetext{
${ }^{169}$ Convertida, com a aprovação do Congresso Nacional, na lei 9.069 de 27.06.95.

${ }^{170}$ Indústria e Comércio, Trabalho, Agricultura e Previdência.

${ }^{171}$ BASA, BB, BNB, BNDES e CEF.
} 
sujeita aos regimes acima mencionados. Protege créditos de depositantes (depósitos à vista, depósitos de poupança, letras de câmbio, letras imobiliárias e letras hipotecárias, de emissão ou aceite de instituição financeira ou associação de poupança e empréstimo) até um limite de $\mathrm{R} \$ 20.000,00$. Devem participar todas as instituições financeiras com exceção das cooperativas de crédito e as seções de crédito das cooperativas, contribuindo mensalmente com $0.025 \%$ do saldo das contas correspondentes às obrigações.

\section{II.3.1.2.3. Abertura comercial unilateral.}

A segunda estratégia jurídica implantada foi a abertura comercial unilateral - a redução ou remoção de barreiras explícitas e implícitas à entrada e operação, no mercado doméstico, de instituições financeiras estrangeiras. Isso implica a implementação de dois tipos de medidas: medidas não-discriminatórias e medidas de melhoria de acesso a mercado.

O grande empecilho do processo de abertura era constitucional. O artigo 52 do Ato das Disposições Constitucionais Transitórias da CF/88 veda, até a regulamentação do art. 192 da Constituição, que estrangeiros se instalem no pais ou ampliem sua participação no capital de instituições domésticas. A solução encontrada foi recorrer a uma exceção a essa regra. Permite-se no parágrafo único do mesmo artigo que a vedação seja afastada no caso de acordos internacionais, reciprocidade ou interesse do Governo Brasileiro. O que se decidiu foi regulamentar a cláusula sobre interesse governamental por meio da Exposição de Motivos n ${ }^{\circ} 3116$, de 23/8/95, permitindo que o Presidente da República pudesse autorizar caso a caso e em caráter excepcional a entrada de bancos estrangeiros no país. Essa medida se juntou a outras formas de investimentos no setor financeiro progressivamente permitidas desde o final da década de 1980: investimentos em renda fixa e ações nos termos dos anexos I, II, III e IV da Resolução n ${ }^{\circ} 1.289$ de março de 1987 e suas modificações contidas nas Resoluções 1.806/91, 1.832/91, 1.907/92 e 2.034/93.

Menciona-se também a extinção da carta-patente e criação dos bancos múltiplos, que auxiliaram na racionalização do funding dos bancos ao mesmo tempo que reduziram as restrições à abertura de novas instituições financeiras. A partir da Resolução CMN 1.524, passou-se a condicionar a abertura de instituições financeiras a critérios 
relacionados com níveis de capital, grau de alavancagem máximo e idoneidade do controlador. Não havia mais restrições quantitativas como cartas-patente - autorizações de abertura de bancos que são negociáveis e transferíveis.

\section{II.3.1.3. Estrutura jurídica da integração européia.}

O processo de integração financeira européia é, por excelência, um projeto de integração regional plurilateral. Nos termos narrados acima, congrega dois momentos. O primeiro foi levado a cabo por meio do Programa 1992 e foi centrado na integração dos mercados bancários. O segundo teve como foco os mercados de valores mobiliários e foi efetivado por meio do Plano de Ação para Serviços Financeiros.

Em ambos os casos a estratégia jurídica utilizada foi semelhante na sua complexidade. Iniciou-se com a autoridade comunitária (Parlamento Europeu ou Conselho Europeu, ou ambos) editando diretivas explicitando as metas de harmonização e as condições gerais de mútuo reconhecimento; envolveu uma intensa negociação com os governos nacionais e com as autoridades financeiras domésticas; apoiou-se na edição de normas de diversas naturezas: desde normas comunitárias como diretivas e regulamentos, até as normas que possibilitaram a incorporação doméstica das normativas comunitárias, como leis e decretos.

Como resultado, o pacote de medidas e mudanças institucionais não teve um viés único, assumindo aspectos de acordos comerciais, harmonização, reconhecimento, cooperação internacional e convergência. Ressaltam-se aqui cinco elementos principais:

\section{II.3.2.3.1. Harmonização regulatória.}

Foi essencial nas diversas etapas do processo de integração financeira europeu que critérios mínimos para autorização e operação de instituições financeiras fossem acordados. Isso implicou:

(1) Negociação e edição de normativas contendo critérios harmonizados mínimos. Conduzido pela Comissão Européia em ambos os casos, o processo de desenvolvimento e adoção de diretivas visando à adoção de normas harmonizadas foi bastante técnico e complexo. Autoridades nacionais, em conjunto com a Comissão Européia, desenvolveram um conjunto de normas comuns sobre 
diversos aspectos das atividades financeiras. Tais normas foram, então, introduzidas como Diretivas pelo Conselho e pelo Parlamento Europeu.

(2) Processo de adaptação e implementação das normativas nacionais. Uma vez aprovadas as diretivas harmonizadoras, foi necessário garantir que os governos nacionais aprovassem reformas regulatórias. Um intenso programa de monitoramento foi posto em prática.

(3) Isolamento técnico-burocrático. Matérias de natureza financeira são tradicionalmente tratadas pela União Européia e seus governos nacionais como técnicas e sensíveis. A participação de burocratas é privilegiada, sendo que é bastante raro participação direta do Parlamento Europeu ou de grupos da sociedade civil. Escaldado com as dificuldades por que passou a implementação do Programa 1992, a União Européia, para aprovar as modificações, decidiu adotar o chamado "Processo Lamfalussy" - abordagem de quatro níveis, quais sejam: (i) Parlamento Europeu e Conselho da União Européia adotam legislação estabelecendo valores e princípios, linhas-mestras e cronograma para implementação de diretivas; (ii) comitês específicos são constituídos com representantes nacionais, reguladores nacionais servem de consultores, e detalhes técnicos são decididos e trazidos a voto; (iii) reguladores nacionais implementam as normas específicas aprovadas pelos comitês nacionais; (iv) a implementação em nível nacional das normas é supervisionada.

(4) Elementos-chave. São elementos-chave das obrigações de harmonização contidas nas diretivas aprovadas no bojo de ambos programas : (i) procedimentos de autorização; (ii) condições de operação; (iii) supervisão e instituições reguladoras nacionais; (iv) condições de cooperação entre autoridades nacionais; (v) relacionamento com terceiros países.

\section{II.3.1.3.2. Autorização única: "Passaporte Europeu".}

Ao lado do sistema harmonizado de autorização para operação de instituições financeiras européias, as diretivas estabelecem um sistema de reconhecimento mútuo. Uma vez que a autoridade nacional de qualquer um dos países-membros autorize a abertura, seja de uma instituição de crédito, seja de uma empresa de investimento, tal 
autorização é automaticamente estendida às operações da referida instituição nos outros países-membros.

\section{II.3.1.3.3. Política comum para terceiros países.}

As diretrizes prevêem também princípios comuns para (i) tratamento de instituições financeiras cujo país sede seja um terceiro país, (ii) regras de cooperação com autoridades de terceiros países, (iii) normas sobre o tratamento de investidores estrangeiros ou de terceiros paises, (iv) normas comuns de reciprocidade e tratamento nacional para instituições de terceiros países, (v) normas sobre reconhecimento de regras editadas por autoridades estrangeiras. Em relação às duas últimas categorias, são dados à Comissão Européia poderes para rever a compatibilidade e propriedade do tratamento outorgado pela autoridade européia à autoridade do terceiro pais.

\section{II.3.1.3.4. Cooperação em supervisão financeira.}

As diretrizes estabelecem também regras harmonizadas sobre poderes, mandato, procedimentos de investigação e punição de infrações, e outros aspectos institucionais dos reguladores nacionais em matéria financeira. Entre as regras harmonizadas, menciona-se: (1) regras sobre poderes e autoridades dos reguladores nacionais; (2) regras sobre sanções e poderes de investigação de infrações regulatórias; (3) regras sobre revisão de decisões administrativas; (4) regras de sigilo; (5) regras de cooperação entre autoridades.

\section{II.3.1.3.5. Coordenação em supervisão financeira: Regra do país de origem.}

Ao lado do sistema harmonizado de supervisão e operação dos reguladores financeiros domésticos, foram também estabelecidas regras de reconhecimento mútuo. Uma vez que uma instituição financeira é autorizada a funcionar por determinado paísmembro (chamado de país de origem), tal país retém autoridade para aplicar suas normas e seu regime regulatório à exclusão da autoridade do país-hóspede, salvo exceções. Em conseqüência, o país de origem é responsável pela supervisão consolidada das operações da instituição financeira e pela análise das atividades das filiais estrangeiras. Além disso, a instituição deve cumprir os requisitos estabelecidos pelos reguladores do país-origem. 


\section{II.3.1.4. Estrutura jurídica dos acordos da Basiléia.}

Os acordos da Basiléia podem ser classificados como um resultado de movimento plurilateral de harmonização de normas sobre supervisão bancária, e como episódio multilateral de convergência regulatória. Conforme narrado acima, apesar de originaremse de um acordo entre um restrito grupo de países - o G10 -, os acordos tiveram repercussão sobre um grande número de países que não fez parte das discussões originais.

Em teoria, as regras não teriam natureza vinculante alguma. Não foram propostas na forma de tratados, acordos executivos ou mesmo memorandos de entendimentos. Seriam apenas padrões de adesão voluntária, melhores práticas a serem implantadas ao sabor das necessidades e interesses dos países envolvidos. Todavia, por razões referidas supra, adquiriram contornos de obrigatoriedade quase que inescapável.

Em termos substantivos, os acordos da Basiléia lidam com dois tipos básicos de normas: regulação prudencial mínima e padrões mínimos de supervisão. Em relação ao primeiro tipo, determinam critérios harmonizados para requisitos de capital e fórmula para seu cálculo e apuração. Trata-se de harmonização regulatória. Em relação ao segundo, determinam regras para solucionar conflitos de competência e jurisdição, procedimentos e elementos institucionais de supervisão, e regras de intercâmbio de informações regulatórias. Trata-se de esquemas de reconhecimento mútuo, harmonização, e cooperação. Ressaltam-se aqui três elementos principais:

\section{II.3.1.4.1. Regra de solução de conflitos de competência e jurisdição regulatória e de} supervisão.

O primeiro elemento substancial incluído na estrutura jurídica dos acordos de Basiléia é relativo ao estabelecimento de critérios objetivos para definição de competência e jurisdição regulatória e de supervisão. Em relação a instituições financeiras que operam de forma integrada em mais de uma jurisdição, que atravessam, portanto, fronteiras nacionais, buscou-se responder questões como: Qual país deve ter competência de ditar regras prudenciais? A quais regras e a quais autoridades deve este banco obedecer? A autoridade de que país deve ficar responsável pela verificação do cumprimento de quais regras prudenciais? 
A Concordata de 1975 definia que a responsabilidade deveria ser conjunta, do país-origem e país-hóspede. As subsidiárias e joint ventures deveriam estar submetidas às regras do país-hóspede; já filiais e agências sem personalidade jurídica submetiam-se às regras do país de origem. Tal divisão de tarefas nada mais era do que a prevalência do princípio territorial como regra de solução de conflito inter-jurisdicional, solução que não gerava atritos excessivos entre autoridades e reduzia a necessidade de colaboração entre reguladores. Tampouco havia nos termos da Concordata a sugestão de que deveria haver um supervisor consolidado.

Sob o impacto da crise do BCCI, todavia, esse arranjo não resistiu: os Bancos Centrais dos países do G10 decidiram modificar suas práticas e passar a reconhecer a jurisdição de países estrangeiros sobre bancos operando em território nacional. A Concordata Revisada, de 1983, também definia uma fórmula de alocação de responsabilidades, mas a complementava com exigências de compartilhamento de informações e cooperação.

A solução jurídica encontrada, destarte, era baseada em dois predicados: (i) regulação e supervisão "chave dupla"172, e (ii) eleição de um consolidador. Em relação ao (i) primeiro, quer dizer que os países-hóspedes também deveriam se sentir confortáveis com a supervisão incidindo sobre a instituição-matriz. Teriam, assim, o direito de recusar que a filial se instalasse ou operasse em seu território caso a matriz não estivesse em conformidade com as regras locais. Quanto ao (ii) segundo, a preocupação dirigia-se principalmente às organizações bancárias complexas, aquelas entremeadas por holdings e empresas não-bancárias. A demanda era, nesses casos, de que as autoridades de referência envidassem esforços para trabalhar em conjunto e consolidar a supervisão dessas organizações que, de resto, seriam excepcionais. No primeiro (i) caso, portanto, sugeriu-se o reconhecimento de uma certa projeção extraterritorial de autoridade regulatória e de supervisão, legitimando-se o uso os ativos em território doméstico como fonte de poder de barganha para garantir a aplicação das regras locais; no segundo (ii) caso, demandou-se a intensificação da colaboração bilateral.

\footnotetext{
${ }^{172}$ No original em inglês, dual key.
} 
Outrossim, em termos materiais, passou-se a exigir que três aspectos fossem enfocados por países-hóspedes na supervisão de instituições estrangeiras: (i) solvência, (ii) liquidez, e (iii) operações de câmbio e posições cambiais.

\section{II.3.1.4.2. Harmonização regulatória e de padrões de supervisão.}

Com o início da operação dessa tímida versão de política de reconhecimento mútuo, problemas e atritos surgiram, principalmente no que tange a definição de critérios para avaliar solvência e liquidez. Era necessário, destarte, reduzir os pontos de fricção. Discussões tiveram que ser aprofundadas, e em 1988 foram adotados critérios harmonizados para contabilização de ativos e requisitos mínimos de capital $^{173}$. A definição de capital adotada tinha duas partes: (i) constituintes do capital, e (ii) critérios de ponderação. Quanto à (i) primeira parte, são dois os itens fundamentais: principal (fundos ou ativos próprios) ${ }^{174}$ e reservas. Quanto à (ii) segunda parte, trata-se de fatores de ponderação que devem ser aplicados às diversas categorias de ativos fazendo parte do capital do banco. O risco da contraparte entra, portanto, no cálculo do valor do ativo. Tais fatores são talvez os pontos mais controversos do acordo.

A determinação do segundo elemento do Acordo, requisitos mínimos de capital, também causou controvérsia. Quedou, no entanto, acertada para 8\%, sendo estabelecido um prazo para que fosse implantado.

Mais uma vez, é importante frisar: trata-se de um acordo que, apesar de sua falta de obrigatoriedade ou auto-executoridade, teve uma impressionante adesão entre os países que os negociaram. Mais relevante ainda foi a adoção dos acordos por parte de países que não participaram das negociações originais.

\section{II.3.1.4.3. Cooperação em matéria regulatória e de intercâmbio de informações.}

O reconhecimento da necessidade de consolidação regulatória e de supervisão, por um lado, e o inesperado aumento do público a que se dirigiam os acordos da Basiléia, por outro, criaram novas necessidades. O país-origem da instituição financeira poderia ser diferente do país-origem do grupo ou holding; ambos países poderiam reivindicar o

\footnotetext{
${ }^{173}$ Supra, quando da exposição do histórico do processo, mencionaram-se as motivações políticas e nuances da definição do processo. Cumpre aqui apenas expor a estrutura jurídica pela qual tais decisões foram postas em prática.

${ }^{174}$ Chamado de core capital no Acordo da Basiléia.
} 
status de regulador-supervisor consolidado. Além disso, os acordos passaram a cobrir o relacionamento entre países desenvolvidos e emergentes. Com isso, a discrepância de qualidade da regulação e dos supervisores aumentou também. Essa discrepância foi ficando mais relevante na mesma proporção em que a exposição dos bancos multinacionais aos mercados emergentes aumentou.

Nesse contexto, os acordos da Basiléia passaram exercer uma outra função: a de instrumento de coordenação e cooperação financeira entre autoridades de países desenvolvidos e emergentes. O principal mecanismo jurídico que permitiu essa evolução foi a condicionalidade. Com a extraterritorialidade da supervisão reconhecida, as autoridades dos países-origem passaram a exercer de forma mais assertiva a possibilidade a elas aberta de impor condições sobre a operação no estrangeiro de instituições financeiras doméstica. Em particular, a idéia de que poderiam impor requisitos diferenciados de capital para subsidiárias e filiais em países de supervisão e regulação considerada insatisfatória tornou-se um eficaz instrumento para exercer pressão sobre autoridades bancárias estrangeiras.

Além disso, havia o reconhecimento de que países-hóspedes também poderiam questionar a qualidade de supervisão do país-origem e impor maiores restrições (inclusive restrições discriminatórias) às atividades em mercado doméstico de instituições financeiras estrangeiras baseadas em países emergentes. Bancos cuja matriz estava localizada, ou em mercados emergentes ou em mercados menores, estavam sujeitos aos padrões estipulados pelos maiores mercados, e as autoridades dos mercados menores viram-se pressionadas a promover mudanças em suas práticas e regras de supervisão, até para evitar que suas instituições indígenas fossem punidas em mercados estrangeiros grandes.

Esse conjunto de mecanismos jurídicos e informais de aplicação extra-territorial gerou, portanto, condições ideais para o surgimento de um mecanismo de cooperação regulatória e intercâmbio de informações que tinha como foco coordenador as autoridades financeiras de países de grande poder de barganha em vista do tamanho de seus mercados. 


\section{II.3.1.5. Estrutura jurídica da cooperação regulatória na IOSCO.}

A cooperação regulatória entre membros da IOSCO está bastante vinculada ao desenvolvimento da malha de acordos de cooperação bilateral desenvolvida pelas autoridades regulatórias norte-americanas em seu esforço no sentido de viabilizar a aplicação de sua legislação sobre investidores baseados no estrangeiro. Conforme narrado acima, o modelo transplantado para a arena multilateral bebe na solução bilateral adotada pelos Estados Unidos para conseguir maior eficácia em suas investigações de ilícitos no mercado de capitais. Baseia-se em acordos executivos infra-legais entre reguladores, e não tratados internacionais entre governos. Tais acordos são bastante restritos quanto ao escopo e especializados quanto ao tipo de colaboração solicitada. De fato, pode-se dizer que o acordo multilateral só pode ser implantado porque muito das resistências que eventualmente pudessem se apresentar já haviam sido limadas pela estratégia bilateral norte-americana.

A linguagem do Memorando de Entendimento Multilateral e a de muitos dos compromissos bilaterais é eivada de obrigações de "melhores esforços". Isso quer dizer que o grau de vinculação criado é baixo, e os documentos deixam bastante espaço para discricionariedade. A cooperação, portanto, é baseada na reciprocidade quotidiana e na reputação das agências reguladoras. Ao mesmo tempo, todavia, os memorandos são autorizativos: constituem-se fundamentos jurídicos para a cooperação, justificando e legitimando a eventual ação de cooperação dos burocratas, e autorizando atos praticados em cumprimento do objeto e no escopo do acordado.

Em termos substantivos, é dominante o aspecto cooperativo dos acordos. Existe também um viés de harmonização de procedimentos institucionais, que, apesar de secundário, é importante. Ressaltam-se aqui dois elementos principais:

\section{II.3.1.5.1. Obrigação de sigilo e limitação de uso das informações recebidas e enviadas.}

A obrigação mais forte inscrita no Memorando Multilateral e nos Memorandos Bilaterais é aquela que garante o sigilo das informações repassadas ao mesmo tempo que permite seu uso em procedimentos investigatórios e judiciais. É importante ressaltar dois aspectos de tais garantias. Primeiro, como garantia de devido processo, ela permite que evidências e documentos coletados por meio de recurso à cooperação internacional sejam 
utilizadas para fazer prova. Isso implica blindagem jurídica da informação enviada, dificultando sua impugnação.

Segundo, ao proteger o sigilo das informações e limitar sua utilização, a cláusula resguarda a contraparte na cooperação - a autoridade requisitada tem maiores garantias de que as informações produzidas não serão utilizadas para fins não desejados. Isso tem como efeito o aumento da credibilidade na cooperação, e torna as autoridades estrangeiras mais afeitas ao trabalho conjunto. Como conseqüência, tem-se uma melhor blindagem jurídica do acordo de cooperação transjuridiscional em si, preservando as autoridades de questionamentos.

\section{II.3.1.5.2. Harmonização de procedimentos.}

Em suas definições e nos procedimentos que descrevem, o Memorando Multilateral e grande parte dos Memorandos de Entendimento bilaterais determinam um protocolo básico de cooperação. Incluem-se nesse protocolo requisitos do requerimento básico, da resposta, e do processamento, com indicação das autoridades competentes e das ações esperadas.

Isso implica padronização de trâmite junto aos reguladores, definição de uma linguagem harmonizada que facilita a comunicação inter-agências regulatórias, e torna a tramitação dos pedidos mais expedita. A rotinização em nível internacional da assistência mútua permite que comparações internacionais sejam estabelecidas entre o funcionamento dos órgãos de fiscalização. Cria, portanto, incentivos para que a relação entre as agências suba de patamar, e, em certo grau, dá condições para que certa competição regulatória tenha lugar, o que pode trazer melhoras do ponto de vista da organização de procedimentos internos.

Regras claras e harmonizadas de cooperação geram também economias de escopo e escala, ao lado de ganhos com consistência, certeza jurídica e previsibilidade. Reduzem-se, portanto, os custos gerais de se cooperar, e aumentam a efetividade.

Um outro aspecto importante é que, ao clarificar e padronizar tais procedimentos, o Memorando Multilateral estabelece balizas que podem inspirar as regras de agências que, ou não podem por motivos de incompatibilidade aderir ao sistema multilateral de cooperação, ou não o desejam fazer por motivos de oportunidade e estratégia. No primeiro caso, podem servir de guia para reformas regulatórias; no segundo caso dão 
previsibilidade ao permitir o dimensionamento dos custos e benefícios de participação do sistema multilateral.

\section{II.3.1.6. Estrutura jurídica da abertura comercial de serviços financeiros na OMC.}

O Acordo de Serviços Financeiros da OMC é um complexo exemplo de tratado multilateral de comércio. É instrumento intergovernamental que é negociado por diplomatas, e precisa ser ratificado para ter efeitos jurídicos. Conforme narrado acima, no caso específico dos serviços financeiros da $\mathrm{OMC}$, as negociações envolveram todos os países membros, e resultaram em concessões comerciais de mais de 70 países.

Apesar do objeto e do estilo de negociação serem contemporâneos, aplicam-se as regras procedimentais e materiais do clássico direito internacional público. Além disso, por estarem submetidas ao contexto negociador do sistema GATT/OMC, utilizam-se a linguagem, os conceitos normativos e regras jurisprudenciais desenvolvidas por mais de meio século de negociações multilaterais de comércio internacional. Com a entrada em vigor $^{175}$ do Quinto Protocolo sobre o GATS (“Acordo sobre Serviços Financeiros" FSA), sete instrumentos (tratados) perfazem a estrutura jurídica que molda a liberalização no setor de serviços financeiros. São eles: (1) GATS; (2) O Anexo do GATS sobre Serviços Financeiros; (3) o Entendimento sobre Compromissos nos Serviços Financeiros; (4) o Anexo do GATS sobre as Isenções do Artigo II e as Listas de Isenções do Artigo II; (5) as Listas sobre Compromissos Específicos; (6) o Segundo Protocolo sobre o GATS; e (7) o Quinto Protocolo sobre o GATS.

O objetivo de todo o sistema é auxiliar na redução de barreiras aos fluxos econômicos entre os países, aumentando a interdependência das economias, promovendo uma mais eficiente organização mundial da produção, e criando um mundo mais estável. Trata-se, portanto, de um acordo comercial, com todos os predicados a ele relacionados. Tem em vista facilitar a operação transfronteiriça e o movimento internacional de consumidores e prestadores de serviços financeiros. Ressaltam-se desse emaranhado de regras os seguintes elementos principais:

II.3.1.6.1. O GATS, suas regras e princípios fundamentais: Não-discriminação e reciprocidade.

${ }^{175}$ Vide supra para o histórico das negociações. 
O GATS é um acordo-moldura composto por 29 artigos divididos em seis partes, quais sejam: (i) Escopo e Definições (Artigo I); (ii) Obrigações e Disciplinas Gerais (Artigos II a XV); (iii) Compromissos Específicos (Artigos XVI a XVIII); (iv) Liberalização Progressiva (Artigos XIX a XXI); (v) Provisões Institucionais (Artigos XXII a XXVI); (vi) Provisões Finais (Artigos XXVII a XXIX). Suas regras têm quatro funções principais: (a) facilitar negociações visando à abertura de mercados, (b) conseguir aderência das partes, (c) proporcionar critérios para interpretação, e (d) estruturar mecanismos institucionais para gerenciar procedimentos de solução de controvérsias.

No cerne do acordo estão dois tipos de obrigações essenciais: obrigações de nãodiscriminação e obrigações de reciprocidade. Com base nesses dois elementos, é negociado acesso a mercado - como e em que condições instituições financeiras estrangeiras e outros prestadores de serviços podem adentrar o mercado doméstico. Como será visto abaixo, com acesso a mercado aponta-se para obrigações de redução de barreiras comerciais a importações, independentemente delas serem discriminatórias ou não. Já o termo não-discriminação implica dois tipos de obrigações:

- Tratamento (ou cláusula) de Nação Mais Favorecida ${ }^{176}$. Num contexto bilateral, significa que governo que a assume se compromete a outorgar automaticamente ao parceiro comercial as melhores condições acertadas com qualquer terceira parte. Num contexto multilateral, significa que o governo que a assume se compromete a outorgar automaticamente a todos os parceiros comerciais as melhores condições acertadas com qualquer parte ou terceira ou não.

- Tratamento Nacional $^{177}$. Num contexto bilateral, significa que o governo que a assume se compromete a outorgar automaticamente ao parceiro comercial as mesmas condições recebidas pela indústria domestica. Num contexto multilateral, significa que o governo que a assume se compromete a outorgar automaticamente a todos os parceiros comerciais as mesmas condições recebidas pela indústria doméstica.

Quando um país A negocia um acordo comercial sobre serviços financeiros com um país B, o que deseja é conseguir compromissos de duas ordens do país B: (i) que o

${ }^{176}$ MFN - Most Favoured Nation. [doravante MFN].

${ }^{177}$ NT - National Treatment [doravante NT]. 
país B retire medidas que impedem importações de serviços fornecidos por instituições financeiras do país A e vice-versa; ou (ii) que o país B pare de discriminar serviços adquiridos do país A. A discriminação se concretiza, seja por meio de (a) tratamento menos favorável em relação ao recebido pelas instituições financeiras provenientes de qualquer outro parceiro comercial, seja por (b) tratamento menos favorável em relação ao recebido pelas instituições financeiras nacionais.

Em relação às regras substanciais, muitas das outras obrigações contidas no GATS podem ser entendidas, ou como exceções a um dos princípios (ou a ambos), ou como aplicações dos princípios a casos específicos. Encontram-se nessa situação a maior parte das regras da Parte I do acordo, notadamente as regras referentes a regionalismo, regulação doméstica, reconhecimento mútuo, monopólios, práticas mercantis, salvaguardas e outras medidas emergenciais, compras governamentais, e exceções gerais e específicas. O restante do acordo trata, seja de processo negocial (mandato dos negociadores, harmonização de linguagem, regulação de ofertas e pedidos, formalidades em relação a compromissos, prazos e procedimentos), seja de aspectos institucionais (órgãos a serem criados, poderes e solução de controvérsia).

\section{II.3.1.6,2. Regras procedimentais, mandato negociador permanente e liberalização progressiva.}

No que tange às regras procedimentais, o coração da disciplina é o Artigo XIX da

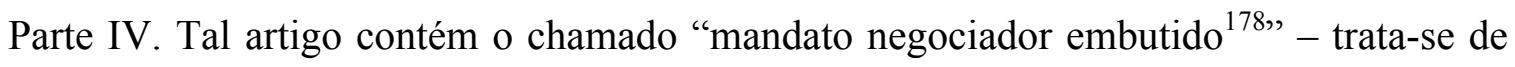
disposição que estabelece uma obrigação de se realizar rodadas de negociação periódicas, dando prazos e condições para que elas aconteçam.

O Parágrafo 3 induz negociadores a intercambiar compromissos em duas dimensões: horizontal (a linguagem é "comércio de serviços em termos gerais" ${ }^{179}$ ) e

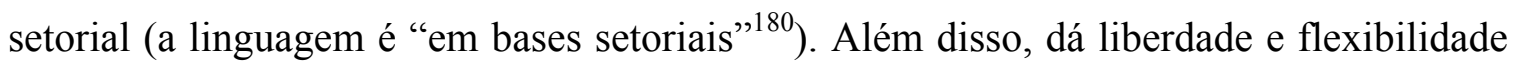
para a adoção de diferentes dinâmicas negociadoras. A atual, por exemplo, foi definida em 2001 no documento $\mathrm{S} / \mathrm{L} / 93^{181}$. Trata-se de uma formalização e racionalização do

\footnotetext{
${ }^{178} \mathrm{Na}$ terminologia de comentadores, o built-in mandate.

${ }^{179}$ No original: trade in serviços in overall terms.

${ }^{180}$ No original: on a sectoral basis.

${ }^{181}$ Vide (World Trade Organization, Council on Trade in Services 2001).
} 
procedimento utilizado durante a Rodada Uruguai e durante as negociações do segundo e quinto protocolos. Os principais pontos do procedimento adotado são:

- As negociações devem ocorrer em Sessões Especiais do Conselho sobre Comércio de Serviços;

- As negociações devem se transparentes e abertas a todos os Membros, e seu ponto de partida devem ser as listas de compromissos existem, sem prejuízo ao conteúdo dos pedidos de outros Membros;

- As negociações devem avançar por meios bilateriais, plurilateriais e multilaterais;

- A principal fórmula de negociação deve ser a de "pedido-e-oferta".

Esses elementos apontam para um tradicional e complexo método de negociação que remonta à técnica "linha por linha" utilizada no GATT até a Rodada Kennedy. Nela, obter maior acesso a mercado implica sentar-se com diversos parceiros comerciais e discutir com eles individualmente concessões bilaterais. Com a fórumula "pedido-eoferta”, a seqüência de passos é a seguinte. Numa primeira fase, os países iniciam por consultar suas empresas de serviços domésticas sobre quais mercados estrangeiros gostariam de ver abertos. Isso implica descobrir qual setor, em primeiro lugar, e qual país, em segundo lugar, interessam a suas companhias. Todas essas informações são reunidas na forma de pedidos.

$\mathrm{Na}$ segunda fase, tais países consultam bilateralmente os parceiros cujos mercados específicos interessam, e a cada um deles entregam seus pedidos. Países que fazem pedidos são chamados demandeurs. Os negociadores dos países demandados levam, então, os pedidos recebidos às capitais. O governo de cada país discute internamente o que podem ofertar, descobrindo o teto de sua posição negociadora. Com fundamento nesse teto, definem uma estratégia.

$\mathrm{Na}$ terceira fase, é marcada uma data na qual as ofertas iniciais serão apresentadas. Normalmente, tais ofertas são um piso - uma sinalização de prioridades. Isso é assim porque as ofertas não são feitas bilateralmente - elas são entregues de forma centralizada ao Secretariado da OMC, que se encarrega de as revelar a todos os outros países simultaneamente. Pedidos, portanto, são muitos; ofertas, ao contrário, são listas unitárias, consolidadas por país. Para incentivar Membros a entregarem ofertas, a partir 
da data-limite só têm acesso às ofertas de outros parceiros aqueles que já fizeram sua parte e entregaram suas ofertas.

Na quarta fase, é marcada uma data na qual serão feitas as chamadas ofertas melhoradas. De posse das ofertas iniciais, os Membros as confrontam com seus pedidos. Têm, então, prazo até a data da entrega das ofertas melhoradas para negociar bilateralmente com os parceiros cuja oferta inicial, em sua opinião, deixou a desejar. Podem oferecer em troca melhorias em sua própria oferta, de modo a contemplar o parceiro. Negociações bilaterais ocorridas, novamente listas consolidadas são entregues ao Secretariado, que centraliza o processo. Terminado o prazo das ofertas melhoradas, o secretariado revela aos Membros as ofertas consolidadas. Com todas as listas de ofertas na mesa, os Membros decidem coletivamente, então, se aceitam o que foi oferecido.

\section{II.3.1.6.3. Subsetores, modos de prestação e listas de compromissos.}

Para que a fórmula "pedido-e-oferta" funcione, é necessário saber sobre o que se negocia. Em outras palavras, é preciso que se padronize o conteúdo dos pedidos e ofertas. Isso é feito duas formas. Em primeiro lugar, estabeleceu-se uma lista classificatória de serviços, a chamada lista W120 ${ }^{182}$. Nessa lista, o setor de serviços financeiros aparece dividido em dois subsetores principais - o (A) Subsetor de Seguros e Relacionados aos Seguros e (B) o Subsetor de Serviços Financeiros Bancários e Outros (excluídos os seguros). Além disso, o Artigo 5 do Anexo sobre Serviços Financeiros traz uma lista contendo definições de serviços financeiros:

${ }^{182}$ (Multilateral Trade Negotiations, Trade Negotiations on Services 1991) 
5. Definitions

For the purposes of this Annex:

(a) A financial service is any service of a financial nature offered by a financial service supplier of a Member. Financial services include all insurance and insurance-related services, and all banking and other financial services (excluding insurance). Financial services include the following activities:

Insurance and insurance-related services

(i) Direct insurance (including co-insurance):

(A) life

(B) non-life

(ii) Reinsurance and retrocession;

(iii) Insurance intermediation, such as brokerage and agency;

(iv) Services auxiliary to insurance, such as consultancy, actuarial, risk assessment and claim settlement services.

Banking and other financial services (excluding insurance)

(v) Acceptance of deposits and other repayable funds from the public;

(vi) Lending of all types, including consumer credit, mortgage credit, factoring and financing of commercial transaction;

(vii) Financial leasing;

(viii) All payment and money transmission services, including credit, charge and debit cards, travellers cheques and bankers drafts;

(ix) Guarantees and commitments;

(x) Trading for own account or for account of customers, whether on an exchange, in an over-the-counter market or otherwise, the following:

(A) money market instruments (including cheques, bills, certificates of deposits);

(B) foreign exchange;

(C) derivative products including, but not limited to, futures and options;

(D) exchange rate and interest rate instruments, including products such as swaps, forward rate agreements;

(E) transferable securities;

(F) other negotiable instruments and financial assets, including bullion.

(xi) Participation in issues of all kinds of securities, including underwriting andplacement as agent (whether publicly or privately) and provision of services related to such issues;

(xii) Money broking;

(xiii) Asset management, such as cash or portfolio management, all forms of collective investment management, pension fund management, custodial, depository and trust services;

(xiv) Settlement and clearing services for financial assets, including securities, derivative products, and other negotiable instruments;

(xv) Provision and transfer of financial information, and financial data processing and related software by suppliers of other financial services;

(xvi) Advisory, intermediation and other auxiliary financial services on all the activities listed in subparagraphs ( $v$ ) through (xv), including credit reference and analysis, investment and portfolio research and advice, advice on acquisitions and on corporate restructuring and strategy.

(b) A financial service supplier means any natural or juridical person of a Member wishing to supply or supplying financial services but the term "financial service supplier" does not include a public entity.

Em segundo, foi definido que cada um dos compromissos a serem assumidos, além de nomear o subsetor a que se relaciona, deve identificar um ou mais modos de prestação de referência.. Os modos básicos de prestação de serviços foram definidos como sendo quatro: 
- Modo 1: comércio transfronteiriço de serviços - Identifica uma forma de prestação evolvendo o movimento do próprio serviço entre países membros. Portanto, as medidas restritivas atacadas são aquelas que evitam um serviço de cruzar as fronteiras dos países.

- Modo 2: consumo no exterior. Liga-se ao movimento de consumidores. Assim, as medidas restritivas atacadas são aquelas que impedem ou dificultam que consumidores deixem seu país de origem - ainda que virtualmente, como no caso do comércio eletrônico - e dirijam-se a outro país para consumir determinado serviço.

- Modo 3: presença comercial. Relaciona-se com o movimento do fornecedor ou prestador de serviço. Destarte, as medidas restritivas atacadas são aquelas que impedem ou dificultam que fornecedores vão ou se estabeleçam em países estrangeiros para levar seus serviços aos consumidores de outro país.

- Modo 4: presença de pessoas físicas. Também refere-se a um movimento do fornecedor ou prestador de serviço. Todavia, as medidas restritivas atacadas nesse caso são aquelas que impedem ou dificultam que pessoas físicas entrem em países estrangeiros com o objetivo de prestar serviços aos consumidores destes países.

\section{II.3.1.6.4. Regras especiais: O Anexo sobre Serviços Financeiros.}

Como parte integrante do GATS, o Anexo se relaciona diretamente ao acordomoldura, de modo a adaptá-lo às especificidades dos serviços financeiros. É vinculante para todos os Membros da $\mathrm{OMC}^{183}$. Define (i) o escopo do GATS em relação a serviços financeiros e (ii) impõe certas regras específicas do setor ${ }^{184}$. É dividido em cinco seções que correspondem, de forma geral, à estrutura do GATS. Vejamos:

\footnotetext{
${ }^{183}$ Vide Artigo XXIX do GATS.
}

${ }^{184}$ Vide (Leroux 2002). 


\begin{tabular}{|c|c|c|c|c|}
\hline \multicolumn{2}{|c|}{$\begin{array}{l}\text { Seção do Anexo Sobre } \\
\text { Serviços Financeiros }\end{array}$} & \multicolumn{2}{|c|}{$\begin{array}{l}\text { Corresponência } \\
\text { com o GATS. }\end{array}$} & \multirow[t]{2}{*}{ Comparação } \\
\hline Número & Matéria & Número & Artigos & \\
\hline Seção 1 & $\begin{array}{l}\text { Escopo e } \\
\text { Definição }\end{array}$ & Parte I & I & $\begin{array}{l}\text { Especifica o escopo do Anexo - serviços financeiros - } \\
\text { e estabelece a aplicação das } 4 \text { modalidades de } \\
\text { prestação de serviço do Artigo I:2 do GATS. } \\
\text { Especifica em relação a serviços financeiros o conceito } \\
\text { de serviços prestados no exercício da autoridade } \\
\text { governamental. } \\
\text { Isenta o setor de serviços financeiros da aplicação do } \\
\text { artigo I(3)(c). }\end{array}$ \\
\hline Seção 2 & $\begin{array}{l}\text { Regulação } \\
\text { Domésitica }\end{array}$ & Parte II & VI & $\begin{array}{l}\text { Amplia exceções do GATS, estabelecendo regime } \\
\text { específico para regulação prudencial. } \\
\text { Estabelece exceções em relação ao sigilo e } \\
\text { confidencialidade de informações. }\end{array}$ \\
\hline Seção 3 & Reconhecimento & Parte II & VII & $\begin{array}{l}\text { Autoriza e especifica o regime de reconhecimento para } \\
\text { medidas prudenciais através de acordos. } \\
\text { Estabelece obrigação de oferecer "oportunidade } \\
\text { adequada" a outros membros que desejem participar } \\
\text { de regime de reconhecimento de medidas prudenciais } \\
\text { acordadas. }\end{array}$ \\
\hline Seção 4 & $\begin{array}{l}\text { Solução de } \\
\text { Disputas e } \\
\text { Aplicação }\end{array}$ & Parte V & XXIII & $\begin{array}{l}\text { Especifica que os painéis para disputas referenes a } \\
\text { medidas prudenciais e ioutras matérias devem possuir } \\
\text { expertise relevante ao serviço financeiro em disputa. }\end{array}$ \\
\hline Seção 5 & Definções & $\begin{array}{l}\text { Parte I } \\
\text { e } \\
\text { Parte VI }\end{array}$ & $\begin{array}{l}\mathrm{I} \\
\mathrm{e} \\
\mathrm{XXVIII}\end{array}$ & $\begin{array}{l}\text { Especifica as categorias de pretação de serviços } \\
\text { financeiros, listando } 16 \text { tipos separados em dois } \\
\text { grupos - (i) seguros e relacionados e (ii) bancários e } \\
\text { outros. }\end{array}$ \\
\hline
\end{tabular}

Fonte: Elaboração própria.

Definições. "Serviços financeiros" são definidos de maneira ampla e nãoexaustiva como serviços de natureza financeira prestados nas quatro modalidades do GATS por qualquer prestador de serviços financeiros ${ }^{185}$ de um Membro ${ }^{186}$. Além disso, considerando-se que o Anexo afirma abranger "medidas afetando a prestação de serviços financeiros", expressão também utilizada no GATS Artigo I:1, tem-se que o âmbito de aplicação do Anexo deve ser interpretado de maneira a não limitar sua aplicação ao domínio regulatório ${ }^{187}$.

${ }^{185}$ A expressão "prestador de serviço" é definida de maneira residual pelo artigo 5(b) como qualquer pessoa, natural ou jurídica, que deseja prestar ou presta serviços financeiros, à exclusão as entidades públicas. Estas últimas são definidas no Artigo 5(c) como (i) autoridade governamental, banco central ou autoridade monetária no exercício de funções governamentais ou atividades com o propósito governamental ou (ii) entidade privada executando as funções relacionadas em (i). Entre as atividades e funções relacionadas com o exercício de autoridade governamental estão as relativas a: (a) políticas monetárias e cambiais; (b) regulação de seguridade social ou pensões e aposentadorias públicas; (c) garantia de depósitos e utilização de recursos financeiros. Vide Arigo 1(b) do Anexo.

${ }_{186}$ Vide Artigo I :2 do GATS, 1(a) e 5(a) do Anexo.

${ }^{187}$ Ao interpretar tal disposição do GATS no caso Bananas III, o Órgão de Solução de Controvérsias afirmou que o termo "afetando" deve ser compreendido como relativo a medidas aplicadas por governos de 
Regras específicas. Uma das questões mais delicadas nas negociações sempre foi a preservação dos poderes regulatórios e da autonomia soberana dos Estados nacionais em definir regras talhadas para garantir a solvência e o bom funcionamento do sistema financeiro. Daí estarem intimamente imbricadas as questões relativas à regulação prudencial e à autonomia de reconhecimento de medidas prudenciais. Quanto às primeiras, o Anexo garante aos Membros a ampla possibilidade de imposição de regras que visem à proteção de investidores, depositantes e detentores de apólices de seguros. No entanto, tais medidas restritivas não podem ser utilizadas como forma de circunvenção das obrigações de liberalização assumidas - seu intuito único é o de preservação da integridade e estabilidade do sistema financeiro ${ }^{188}$. O parágrafo 2 (a) do Anexo engloba o que a literatura especializada convencionou chamar prudential carveout - exceções prudenciais às obrigações de liberalização que não precisam estar relacionadas na lista do Artigo II $^{189}$.

Quanto às segundas, elas referem-se à possibilidade de Membros decidirem soberanamente sobre acordos de reconhecimento de regimes prudenciais. Abrem, portanto, espaço para a compatibilidade com o sistema multilateral de regulação do comércio de sistemas como o europeu, em que o princípio da harmonização e do mútuo reconhecimento, aliados à necessidade de padrões mínimos, permitem a convivência da diversidade regulatória. No entanto, tentam conter um pouco da bilateralização indiscriminada dos acordos, o que geraria instabilidade regulatória, fragmentação das obrigações multilaterais e discrepâncias regulatórias devido à falta de coordenação do sistema. Esse passo é dado com a exigência de que seja oferecida a outros Membros interessados "adequada oportuinidade" para também celebrarem acordos de reconhecimento em termos comparáveis.

Por último, existe no Acordo uma cláusula referente à solução de controvérsias. Ela obriga que, na seleção do painel, seja observada a exigência de expertise no setor

Países-Membros, sejam emanadas de órgãos não-governamentais ou instâncias nacionais, regionais ou locais - no exercicio de poderes governamentais.

${ }^{188}$ Vide Artigo 2(a) do Anexo.

189 Vide (Jarreau 1999; Leroux 2002; Dobson and Jacquet 1998). 
financeiro. Leroux ${ }^{190}$ afirma que a interpretação deste parágrafo 4 do Anexo não obrigatoriamente exige que todos os seus membros sejam experts na matéria em questão.

\section{II.3.1.6.5. O Entendimento sobre os Compromissos em Serviços Financeiros.}

Diferentemente do Anexo, o Entendimento não é parte integral do GATS - apesar de assinado a propósito da Rodada Uruguai, não participou do single undertaking. De fato, configurou-se como acordo plurilateral em que um grupo de países - na sua maior parte desenvolvidos, membros da OCDE - acordou diversas obrigações que, de certo modo, iam além daquelas assumidas no âmbito dos Artigos XVI, XVII e XVIII (Parte III) do GATS. Diz-se que o Entendimento perfaz um "approach alternativo" às negociações (Leroux, 2002; Jarreau, 1999). Por meio dele, compromissos-padrão de 4 tipos foram acordados entre os chamados "Membros interessados": (i) obrigação de stand still (não ampliação das restrições, limitações ou qualificações dos compromissos assumidos para além das existentes); (ii) acesso a mercado (incluindo disposições específicas sobre redução do âmbito e amplitude de direitos de monopólio, tratamento nacional e MFN no que tange a compras de serviços feitas por entidades públicas, comércio transfronteiriço, presença comercial, novos serviços financeiros, transferências e processamento de informação, entrada temporária de pessoal, medidas não-discriminatórias); (iii) tratamento nacional (acesso a câmaras de compensação e sistemas de pagamento públicos, empréstimos de último resort e acesso ou participação em canais regulatórios).

O objetivo do Entendimento seria conciliar o ímpeto negociador dos países (principalmente desenvolvidos) que desejavam obter mais integração de seus mercados financeiros através de garantias ampliadas de previsibilidade de regras e cooperação regulatória, com o temor dos países (principalmente em desenvolvimento) que preferiam um ritmo mais vagaroso de liberalização. Destarte, por meio do Entendimento, foi acertada uma integração "a duas velocidades".

II.3.1.6.6. Segundo e Quinto protocolos: Listas de compromissos em serviços financeiros.

${ }^{190}$ Vide (Leroux 2002). 
O Segundo e o Quinto protocolos são tratados internacionais assinados após a conclusão da Rodada Uruguai que congregam compromissos de abertura de mercado no setor de serviços financeiros da OMC. O segundo protocolo teve validade de aproximadamente dois anos (21 de junho de 1995 a 31 de dezembro de 1997). No cômputo final, 29 Membros (as Comunidades Européias contando apenas como um) submeteram listas de compromisso revisadas para serem anexadas a ele. Tais membros comprometeram-se a enviar o referido Segundo Protocolo à ratificação para que o acordo entrasse em vigor em 20 de junho de 1996. Foi chamado "Acordo Interino". O Quinto Protocolo veio em substituição ao acordo interino. No total, 102 membros comprometeram-se com a liberalização do setor financeiro ${ }^{191}$ : em relação às tratativas da Rodada Uruguai, 70 países melhoraram suas ofertas iniciais e 32 mantiveram as concessões feitas. Foi chamado de "Acordo sobre Serviços Financeiros". Já que se trata de tratado internacional, para entrarem em vigor, os protocolos tiveram de ser enviados as congressos nacionais de cada país para serem submetidos a um processo de ratificação.

\section{II.3.2. Por QUE INTEGRAR MERCAdOS: MODERNIZAÇÃo E CRISE.}

A análise dos casos descritos acima permite entender um pouco mais sobre as motivações dos governos nacionais ao buscarem participar de processos de integração financeira internacional. A tabela abaixo resume as informações sobre natureza, tipo e setor abrangido em cada processo.

\begin{tabular}{|c|c|c|c|c|}
\hline \multirow[t]{2}{*}{ Processo de Integração } & \multirow[t]{2}{*}{ Natureza } & \multirow[t]{2}{*}{ Tipo } & \multicolumn{2}{|c|}{ Setor } \\
\hline & & & Bancário & $\begin{array}{c}\text { Mercado de } \\
\text { capitais }\end{array}$ \\
\hline 1. Abertura unilateral brasileira & Abertura unilateral & Uniletaral & $x$ & $x$ \\
\hline 2. Integração financeira européia & $\begin{array}{l}\text { Reconhecimento e } \\
\text { Harmonização }\end{array}$ & Plurilateral & $x$ & $x$ \\
\hline 3. Acordo da Basiléia sobre requisitos de capital & $\begin{array}{l}\text { Harmonização e } \\
\text { Convergência }\end{array}$ & $\begin{array}{l}\text { Plurilateral e } \\
\text { Multilateral }\end{array}$ & $\mathrm{x}$ & \\
\hline 4. Cooperação entre reguladores na IOSCO & Cooperação & $\begin{array}{l}\text { Bilateral e } \\
\text { Multilateral }\end{array}$ & & $\mathrm{x}$ \\
\hline 5. Acordo sobre serviços financeiros na OMC & $\begin{array}{c}\text { Comércio de } \\
\text { serviços }\end{array}$ & Multilateral & $\mathrm{x}$ & $x$ \\
\hline
\end{tabular}

191 (Dobson and Jacquet 1998). 
Como será explicitado infra, governos nacionais implementam mudanças regulatórias e institucionais (no plano doméstico) e participam da criação de regras, regimes e acordos (no plano externo) visando a conseguir objetivos de política pública determinados. Os estudos de caso apresentados no presente capítulo parecem favorecer a idéia de que há um padrão nas mudanças institucionais que levaram à globalização financeira. Segundo se pode notar das descrições, governos nacionais envolveram-se em processos de abertura financeira mais freqüentemente em dois tipos de situações, quais sejam, situações em que desejam promover a modernização do setor financeiro doméstico, e situações em que são impingidos a lidar com e debelar crises financeiras.

\section{II.3.2.1. Modernização, competitividade, e estratégias de desenvolvimento.}

O primeiro grupo de objetivos buscados pelos governos nacionais ao se envolver em processos de integração financeira é relacionado com a modernização e desenvolvimento do setor financeiro doméstico. Uma das características fundamentais da organização dos sistemas financeiros nacionais é seu relativo insulamento em relação às pressões externas. Escolher participar de um processo de integração financeira específico, portanto, implica promover uma abertura controlada - o governo nacional escolhe a forma pela qual deseja expor seus bancos domésticos a instituições financeiras estrangeiras.

Dentro da rubrica modernização e desenvolvimento, encontram-se quatro categorias principais de objetivos:

(i) Aumento de competição: incluem-se objetivos relacionados a aumentar a competição entre instituições financeiras operando em mercado doméstico. Maior integração implica mais exposição a novos entrantes. Entre os benefícios buscados, encontram-se: custo de capital mais baixo para a economia nacional; maior profundidade do mercado financeiro; maior liquidez do mercado de capitais e menores custos de captação; melhores produtos e maior sofisticação

(ii) Aumento de competitividade: incluem-se objetivos relacionados a melhorar a competitividade das instituições financeiras nacionais na competição com instituições estrangeiras, tanto nos mercados domésticos como nos mercados internacionais. Entre os benefícios buscados encontram-se: melhores produtos, 
maior eficiência organizacional, melhor governança e processos internos, incorporação tecnológica e de know-how, maior acesso e menor discriminação em mercados estrangeiros.

(iii) Maior investimento estrangeiro: incluem-se objetivos relacionados aumentar investimentos estrangeiros em mercados domésticos, em geral, e nos mercados financeiros domésticos, em especial. Entre os benefícios buscados encontram-se: maior crédito doméstico privado, mais crédito e menor custo de captação para governos nacionais, menor exposição e dependência à conjura doméstica com melhor diversificação de riscos, obtenção de mais divisas e rendas para o governo, maior pressão sobre instituições domésticas e incorporação de boas práticas/padrões prudenciais internacionais.

(iv) Desenvolvimento institucional: incluem-se objetivos relacionados a melhorar a qualidade das instituições nacionais. Entre os objetivos buscados estão: maior profundidade e liquidez de mercados; melhoria da qualidade dos regulados e dos reguladores; incorporação de boas práticas e padrões prudenciais internacionais; redução dos riscos institucionais; redução de rendas e aumento de eficiência da burocracia.

\section{II.3.2.2. Crise financeira, regulação prudencial, estratégias de estabilização e proteção da integridade do mercado.}

O segundo grupo de objetivos buscados pelos governos nacionais ao se envolver em processos de integração financeira está relacionado com a recuperação de crises econômicas, estabilização e proteção de investidores. Ao escolher participar de um processo de integração por essas razões, governos nacionais desejam estancar a deterioração de instituições financeiras domésticas e condições econômicas nacionais, utilizando a exposição dos estrangeiros ao país para alavancar a recuperação de capitais, credibilidade e ajuda institucionais.

Dentro da rubrica estabilização e proteção, encontram-se três categorias principais de objetivos:

(i) Melhoria das condições de solvência: incluem-se objetivos relacionados a melhorar as condições de solvência das instituições financeiras operando em 
mercado doméstico. Entre os benefícios buscados, encontram-se: levantar mais capital, nacional ou estrangeiro, para capitalizar e instituições domésticas; mais capital, nacional ou estrangeiro, para financiar o governo; maior acesso a fontes de moeda forte e reservas internacionais; redução de restrições de crédito internacional; melhoria da percepção, confiança, credibilidade e reputação internacionais do pais e das instituições domésticas.

(ii) Melhoria da regulação prudencial:__incluem-se objetivos relacionados a melhorar a regulação prudencial e as condições de governança sob as qual as instituições financeiras operando em mercado doméstico operam. Reformas prudenciais, como quaisquer reformas regulatórias, são complicadas politicamente de serem implantadas considerando-se que contrapõem diversos interesses consolidados. Entre os benefícios buscados, encontram-se: retirar instituições financeiras problemáticas do mercado; colocar seus ativos sob o controle de instituições mais eficientes; modificar coalizões e a conformação das pressões políticas domésticas, criando condições para aprovação de medidas regulatórias mais restritivas; modificar a estrutura de governança das instituições financeiras domésticas; incorporar know how prudencial e melhores práticas financeiras internacionais; aumentar a pressão sobre agências reguladoras e burocracias; alocar e dispersar em nível internacional riscos, e garantir o estabelecimento no mercado doméstico de instituições financeiras com melhores condições de alocar perdas e se proteger.

(iii) Melhoria da proteção de investidores e da poupança nacional: incluem-se objetivos relacionados a melhorar proteção de investidores, auxiliando na prevenção de fraudes, punição de fraudadores e recuperação de perdas. Entre os benefícios buscados, encontram-se: coibir práticas ilícitas afetando investidores nacionais e estrangeiros (fraudes); melhorar o sistema de prevenção e persecução de criminosos no estrangeiro; recuperar ativos e aprimorar o sistema de ressarcimento de investidores fraudados; garantir a credibilidade e a integridade sistêmica dos mercados financeiros e bancários; oferecer maiores garantias a investidores nacionais e estrangeiros. 


\section{II.3.2.3. Quadro Analítico: Processos de integração financeira e suas razões.}

Com base no histórico jurídico-institucional dos casos apresentados acima e no estudo das motivações dos processos de integração financeira, é possível comparar os casos entre si e classificá-los segundo os dois grupos explicitados acima. Tem-se, por conseguinte, o seguinte quadro comparativo:

\begin{tabular}{|c|c|c|}
\hline Processo de Integração e Objetivos & $\begin{array}{r}\text { Modernização e } \\
\text { desenvolvimento }\end{array}$ & $\frac{\text { Estabilização e }}{\text { proteção }}$ \\
\hline \multicolumn{3}{|l|}{ 1. Abertura unilateral brasileira } \\
\hline Recapitalizar instituições domésticas problemáticas e evitar crise financeira. & & $x$ \\
\hline Recuperar a confiança dos investidores internacionais e construir uma reputação de solidez. & & $\mathrm{x}$ \\
\hline Fortalecer o setor financeiro privado. & $\mathrm{x}$ & \\
\hline \multicolumn{3}{|l|}{ 2. Integração financeira européia } \\
\hline $\begin{array}{l}\text { Recapitalizar o sistema bancário, implementar políticas de relançamento econômico e facilitar a } \\
\text { estabilização econômica. }\end{array}$ & & $\mathrm{x}$ \\
\hline Incentivar a absorção de tecnologia, desenvolvimento de novos produtos e redução de preços. & $x$ & \\
\hline Aumentar a competitividade da indústria nacional frente aos estrangeiros. & $x$ & \\
\hline \multicolumn{3}{|l|}{ 3. Acordo da Basiléia sobre requisitos de capital } \\
\hline Reduzir riscos e garantir melhor supervisão sobre o mercado doméstico. & & $x$ \\
\hline Limitar a competição entre bancos domésticos e estrangeiros. & & $x$ \\
\hline Reduzir o diferencial de competitividade entre bancos domésticos e estrangeiros. & $\mathrm{x}$ & \\
\hline Melhorar a credibilidade dos bancos operando em território nacional. & $x$ & \\
\hline \multicolumn{3}{|l|}{ 4. Cooperação entre reguladores na IOSCO } \\
\hline Coibir fraudes e outras práticas ilícitas afetando investidores domésticos. & & $x$ \\
\hline Disciplinar instituições financeiras domésticas e estrangeiras. & $x$ & $x$ \\
\hline $\begin{array}{l}\text { Desenvolver o mercado de capitais doméstico e instituições regulatórias, melhorando sua } \\
\text { credibilidade, profundidade e integridade. }\end{array}$ & $\mathrm{x}$ & \\
\hline \multicolumn{3}{|l|}{ 5. Acordo sobre serviços financeiros na OMC } \\
\hline $\begin{array}{l}\text { Reduzir barreiras para fluxos de capitais e operação transfronteiriça de instituições financeiras, } \\
\text { conseguir maior acesso a mercados estrangeiros para instituições financeiras domésticas. }\end{array}$ & $\mathrm{x}$ & \\
\hline $\begin{array}{l}\text { Expor instituições financeiras domésticas à competição estrangeira, incorporar melhores } \\
\text { práticas e tecnologia bancária. }\end{array}$ & $\mathrm{x}$ & \\
\hline $\begin{array}{l}\text { Melhorar a credibilidade do sistema financeiro doméstico e restaurar a confiança de investidores } \\
\text { estrangeiros, receber investimentos externos, e recapitalizar bancos domésticos. }\end{array}$ & & $x$ \\
\hline
\end{tabular}

\section{II.4. CONCLUSÃO.}

O presente capítulo apresentou reconstruções histórico-institucionais dos seguintes processo de integração financeira: a abertura financeira unilateral brasileira; a formação do mercado financeiro único europeu; a adoção de regras harmonizadas de requisitos de capital do Acordo da Basiléia; a celebração do Memorando Multilateral de Entendimento no âmbito da IOSCO; a assinatura do Acordo sobre Serviços Financeiros 
da OMC. As narrativas tentaram identificar atores, motivações, racionalidades e resultados, de modo a descrever os referidos processos.

Notou-se que, ao contrário do que aduz a hipótese da retração do Estado mencionada na introdução, foi o ativo engajamento de governos nacionais, com objetivos bastante específicos e estratégias definidas de intervenção, que levou à construção de regimes de integração financeira. Cada um dos regimes têm características e naturezas diferenciadas, em vista tanto de seus condicionantes como dos objetivos pretendidos. Também, a partir dos cinco casos analisados, notou-se que ao menos dois fatores impulsionaram governos nacionais a envolverem-se em processos de integração financeira.

O primeiro é a perseguição de estratégias de modernização e desenvolvimento. Essa rubrica diz respeito a políticas de apoio à indústria bancária doméstica, de promoção da concorrência em mercados internos, aprofundamento de mercados financeiros e desenvolvimento institucional.

O segundo é a reação ou combate a crises financeiras domésticas e internacionais. Sob tal categoria incluem-se ações visando à proteção da integridade de mercados financeiros, manutenção da higidez do sistema financeiro, recuperação de liquidez, e fortalecimento institucional.

Percebeu-se também que as estruturas jurídicas criadas também são diversas e sofisticadas. O reconhecimento dessas características torna difícil sustentar que foi a desregulamentação unilateral e liberalização pura e simples que criou condições para o surgimento de mercados financeiros de escala mundial.

Os processos de integração descritos parecem ter criado uma teia jurídica. Formam, portanto a estrutura jurídica descentralizada, multi-polar, heterogênea e de diferentes tecituras, que permitiu o surgimento e operação de instituições financeiras em dois âmbitos:

(i) Ambito multijurisdicional. Instituições operando de forma integrada em diversos países;

(ii) Ambito virtual. Instituições operando sem estarem atreladas a determinado país, ou com tênues relações com uma jurisdição específica. Incluem-se os chamados 


\author{
centros offshore $^{192}$, as Plataformas Multilaterais de Negociação ${ }^{193}$, e os mercados \\ internacionais de valores mobiliários ${ }^{194}$.
}

\footnotetext{
${ }^{192}$ Não existe uma definição conceitual precisa para o termo offshore (International Monetary Fund 2000). Vide também (Roberts 1994). A acepção adotada pelo FMI inclui "where the bulk of financial sector activity is offshore on both sides of the balance sheet, (that is the counterparties of the majority of financial institutions liabilities and assets are non-residents), where the transactions are initiated elsewhere, and where the majority of the institutions involved are controlled by non-residents." (International Monetary Fund 2000). Para esses fins, o Fundo publica uma lista e acompanha as evoluções de diversas localidades. Vide http://www.imf.org/external/np/mae/oshore/2000/eng/back.htm\#tablel.

${ }^{193}$ MTF - Multilateral Trading Facilities [doravante MTPs] são definidas na MiFID como "a multilateral system, operated by an investment firm or a market operator, which brings together multiple third-party buying and selling interests in financial instruments - in the system and in accordance with non-discretionary rules - in a way that results in a contract". Vide Artigo 1(15) da MiFID (European Parliament and Council of the European Union 2004).

${ }^{194}$ Incluem-se aqui os eurobonds markets e os global bonds markets. Vide (Scott and Wellons 2002, 145195).
} 
PARTE 2

EFEITOS DA GLOBALIZAÇÃO FINANCEIRA 


\section{CAPítulo III}

\section{ANÁLISE COMPARATIVA: PROCESSOS DE INTEGRAÇÃO E SEUS EFEITOS}

\section{III.1.INTRODUÇÃO.}

Este capítulo buscará compreender o relacionamento de processos de integração financeira com variáveis econômicas específicas. Partindo das discussões dos capítulos anteriores sobre instrumentos jurídicos e seu uso por governos nacionais no contexto da globalização financeira, realizará uma intensiva análise comparada que utilizará metodologias quantitativas. Para esse fim, construiu-se uma grande base de dados que tabula acordos comerciais, acordos de harmonização, acordos de mútuo reconhecimento e acordos de cooperação.

Tal base de dados será utilizada em análises econométricas que testarão a força da relação entre os processos e indicadores econômicos escolhidos. O que se quer é utilizar a econometria para estabelecer correlações entre integração de mercados financeiros e a ocorrência de determinado processo de integração - aspectos econômicos e aspectos institucionais.

Tradicionalmente, relaciona-se globalização financeira com liberalização, e liberalização com crescimento econômico. Como mostrado acima, há razões para que se duvide de tal explicação simplificadora. Ao estudar alguns casos exemplares de integração financeira, identificou-se uma pluralidade de processos dando suporte à globalização, uma diversidade de objetivos perseguidos por governos para autorizar que estrangeiros adquiriram ativos no mercado doméstico, ou que nacionais adquiram ativos no exterior, e uma atividade política muito relevante de construção institucional acompanhando movimentos de internacionalização. Quer-se agora aprofundar quantitativamente o escopo dessa constatação. 
A estrutura do capítulo é a que se segue. O item (III.2) procederá com uma breve revisão crítica da literatura sobre estudos que tratam de globalização financeira e processos de integração. Na seqüência, em (III.3), proporá um modelo de análise econométrica que incorporará a discussão dos capítulos anteriores. O item (III.4) exporá a metodologia e explicitará informações sobre a base de dados construída paras as análises que se seguem. Finalmente, o item (III.5) discutirá os resultados das regressões realizadas.

\section{III.2. REVISÃO DE LITERATURA: DETERMINANTES E EFEITOS DA GLOBALIZACC̃̃O FINANCEIRA.}

Durante os últimos vinte anos, nota-se a emergência de uma literatura econômica consistente que estuda determinantes e efeitos da globalização financeira. Originalmente, os estudos preocupavam-se com aspectos relativos à liberalização da chamada conta de capitais. Trata-se de um problema bastante restrito e localizado, que envolve um conjunto definido de políticas públicas - aquelas que se referem ao controle direto de fluxos financeiros. Investimentos internacionais, impostos sobre transações financeiras transfronteiriças, restrições a saídas de capitais - era esse o foco de tal linha de pesquisa $^{195}$.

Nesse período inicial a discussão é colocada como uma busca de justificativas para apoiar políticas liberalizantes. A questão subjacente aos textos parece ser a seguinte: existem razões teóricas ou empíricas para que a eliminação de controles de capitais seja implantada unilateralmente por governos nacionais? Na seqüência de artigos, transparece uma tendência a se responder positivamente à pergunta. Do ponto de vista teórico, a liberalização é defendida como medida que tornaria mais eficiente a alocação internacional de fatores de produção (capital e trabalho): países em que o capital é mais escasso passariam a receber investimentos tendo em vista que o rendimento é maior ${ }^{196}$. Com base nessa intuição, diversos autores apresentaram modelos tentando detalhar os mecanismos e canais pelos quais o capital fluiria de países desenvolvidos (em que o

\footnotetext{
${ }^{195}$ Para um rápido sobrevôo sobre estudos, vide (Henry 2007).

${ }^{196}$ Vide (R. I McKinnon 1973; Edwards and Wijnbergen 1986; Dornbusch 1998).
} 
capital abunda) para países em desenvolvimento (em que o trabalho é proporcionalmente menos escasso) ${ }^{197}$.

Do ponto de vista empírico, diversos nós precisavam ser desatados. O primeiro deles era um problema de natureza histórica: ainda que os modelos teóricos previssem uma forte tendência do capital fluir dos países mais ricos para os mais pobres, a maior parte dos fluxos financeiros dava-se entre países desenvolvidos ${ }^{198}$. O segundo era mais sutil. Na teoria, os maiores beneficiários da liberalização da conta de capitais deveriam ser os países em desenvolvimento. Todavia, a evidência desses ganhos eram dúbias e, muitas vezes, inconclusivas. Era difícil encontrar correlações entre crescimento econômico e abertura da conta de capitais ${ }^{199}$. Em terceiro lugar, os dados empíricos passaram a revelar algumas tendências surpreendentes e inesperadas, não previstas pela teoria. Dentre as mais preocupantes estava a relação entre abertura da conta de capitais e crises financeiras. Em alguns estudos e na experiência prática, o aumento da probabilidade de ocorrência de crises financeiras aparecia perigosamente correlacionado com o aprofundamento da liberalização ${ }^{200}$.

Mantendo o viés favorável à liberalização, uma segunda geração de estudos tentou lidar com os percalços enfrentados pela geração anterior. Para esses fins, necessitou ampliar o escopo das análises incluindo elementos institucionais. A intuição subjacente era a seguinte: se a teoria está certa e abertura da conta de capitais é benéfica, algo deve estar bloqueando seus efeitos positivos. A agenda de pesquisa de muitos pesquisadores, portanto, tornou-se buscar as causas das distorções. O escopo da linha de pesquisa ampliou-se, deixando de ser somente políticas referentes à balança de capitais para se transformar em reformas financeiras em geral.

O primeiro caminho explorado foi a questão do seqüenciamento. Autores passaram a postular que a ordem de eliminação das restrições ao fluxo internacional de capitais importava ${ }^{201}$. Nos escritos, é um pouco nebulosa a fundamentação dessa tese.

\footnotetext{
${ }^{197}$ Vide (R. I McKinnon 1973; Fischer 1998; Obstfeld 1998; Rogoff 1999).

${ }^{198}$ Vide, por exemplo, (Helpman and Krugman 1987; Krugman, Obstfeld, and Wesley 2008, 114-153; Obstfeld and Taylor 2004, 230-258).

${ }^{199}$ Vide, por exemplo, (Vittorio Grilli and Gian Maria Milesi-Ferretti 1995; Alesina, V. Grilli, and G. M Milesi-Ferretti 1994)

${ }^{200}$ Vide (Fischer 1998; Bordo 2008; Bordo and Haubrich 2009).

${ }^{201}$ Vide (Diaz-Alejandro 1981; Ronald I. McKinnon 1981; Edwards 1984; Edwards 1989; Falvey and Kim 1992; Mohieldin 1994; Fischer 1997; B. Eichengreen and Mussa 1998; Edwards 2009).
} 
Parece uma idéia bastante intuitiva, imaginar que interações entre políticas públicas poderiam produzir resultados inesperados. Em verdade, do ponto de vista de uma parcela importante do público dessa discussão - organizações internacionais, governos nacionais e responsáveis por políticas públicas - tratava-se de uma solução bastante atrativa. Implicava manter o receituário, mas estabelecer um programa de implementação. Todavia, do ponto teórico, foi uma solução bem pouco elegante. Grosso modo, implicava afirmar que a ordem dos fatores alterava o produto.

O segundo caminho foi ampliar a gama de políticas públicas incluídas sob a rubrica "abertura financeira". Passou-se a se tratar, não mais de abertura da conta de capitais, mas, também, de liberalização de fluxos comerciais e remoção de outros entraves a investidores externos ${ }^{202}$. Foram incluídos no pacote outras grandes reformas macroeconômica e programas de estabilização, o que tornou o conceito abertura algo mais complexo e demandante. Tal aumento de complexidade gerou ganhos em termos de ampliar o campo de pesquisa. Um maior número de fatores passou a ser considerado, e a busca de "determinantes" do crescimento econômico tornou-se mais importante ${ }^{203}$. Talvez tenha também contribuído com a idéia de eventualmente localizar as possíveis fontes de interferências que estariam a distorcer os resultados da liberalização. Em outras palavras, de certo modo essa estratégia ampliou o poder explicativo potencial da teoria. Todavia, em termos práticos, pouco foi o ganho em termos de confirmação ou corroboração empírica. Os mesmos resultados ambíguos subsistiram em diversas análises, e sérias crises financeiras em países que implantaram reformas macroeconômicas nos termos postulados pela teoria voltaram a ocorrer ${ }^{204}$.

O terceiro caminho foi adicionar uma nova dimensão às análises: a dimensão da qualidade das instituições domésticas. Alguns autores passaram a postular que a qualidade do ambiente institucional doméstico nos países em desenvolvimento também teria conseqüências ${ }^{205}$. Em particular está o desenvolvimento dos mercados fínanceiros

\footnotetext{
${ }^{202}$ Vide (B. Eichengreen and Mussa 1998; Gore 2000; Williamson 1990; Kaminsky and Schmukler 2002; Hoxha, Kalemli-Ozcan, and Vollrath 2009; Marangos 2009).

${ }^{203}$ Vide (Klein and Olivei 2008; Henry 2007; Stiglitz 2000; Vittorio Grilli and Gian Maria Milesi-Ferretti 1995; Lemmen and Eijffinger 1996; Vo and Daly 2007)

${ }^{204}$ Vide (Abbott, Andersen, and Tarp; Aizenman, Chinn, and Ito 2008; Bekaert and Harvey 2003; Mishkin 2005; Obstfeld 2009; Stulz 2005)

${ }^{205}$ Vide, por exemplo, (King and Ross Levine 1993a; King and Ross Levine 1993b; Klerman and Mahoney 2007a; Aggarwal and Goodell 2009).
} 
internos. A idéia era a de que, em países que promoveram abertura financeira, o aumento do acesso a capitais internacionais não estaria sendo traduzido em maior crescimento porque aos países em desenvolvimento faltariam instrumentos para aproveitar a maior integração aos mercados financeiros estrangeiros. São duas as intuições por trás dessa abordagem. Em primeiro lugar, está-se a considerar que o direito e as instituições domésticas importam. Em segundo lugar, tem-se que a profundidade e sofisticação dos mercados financeiros domésticos determinam a capacidade de absorver capital internacional. Existem ao menos duas interpretações dessa linha de pensamento. Numa (i) visão mais exigente, o diferencial de sistemas jurídicos implicaria uma barreira difusa ao ingresso de capitais ${ }^{206}$ e certas políticas públicas poderiam implicar repressão financeira ${ }^{207}$. Numa (ii) visão mais benevolente, haveria a necessidade de desenvolver-se estruturas e arranjos que permitam aos investidores estrangeiros operarem no mercado interno $^{208}$. Há na atualidade fortes críticas à primeira (i) interpretação. As mais contundentes são a de que (a) ela não se comprovaria em dados empíricos, (b) a de que estaria baseada numa artificial distinção em common law e civil law que seria excessivamente simplificadora, (b) e a de que levaria a um programa de reformas que seria impraticável por ser excessivamente longo, complexo, e, principalmente, $\operatorname{artificial}^{209}$. Implicaria sempre a importação de instituições estrangeiras, o que, na prática internacional, teria resultados dúbios ${ }^{210}$.

O quarto caminho foi utilizar métodos estatísticos mais sofisticados, tentando isolar supostas interferências de fatores institucionais e eliminar potenciais ruídos que as técnicas econométricas anteriormente utilizadas não davam conta ${ }^{211}$. Essa segunda geração de estudos empíricos tem grandes méritos, principalmente no que tange a melhoria da técnica, por um lado, e a grande produção de dados primários, por outro. Em relação a esta segunda benesse, grandes bancos de dados foram compilados, produzidos e

\footnotetext{
${ }^{206}$ Vide, por exemplo, (Coffee 2007; Daron Acemoglu and Simon Johnson 2005a; Djankov et al. 2003; Klerman and Mahoney 2007b)

${ }^{207}$ Vide, por exemplo, (Amsden and Euh 1993; Calvo 2005; Demirguc-Kunt and Ross Levine 2008; Lardy 2008; Mishkin 2005; Obstfeld 2009).

${ }^{208}$ Vide, por exemplo, (Daron Acemoglu and Simon Johnson 2005b).

${ }^{209}$ Vide, por exemplo, (Klerman and Mahoney 2007b; Roe 2008; Roe and Siegel)

${ }^{210}$ Vide, por exemplo, (Pistor and $\mathrm{Xu} 2005$; Pistor and $\mathrm{Xu}$ 2004)

${ }^{211}$ Vide, por exemplo, (Lemmen and Eijffinger 1996; Kireyev 2002; Vo and Daly 2007; Hoxha, KalemliOzcan, and Vollrath 2009; Ayhan Kose, Eswar S. Prasad, and Terrones 2009; Lagoarde-Segot 2009; Eun and Jinsoo Lee)
} 
disponibilizados, o que provocou um inegável salto de qualidade dos estudos ${ }^{212}$. Todavia, apesar de ampliar a qualidade e quantidade de material disponível para se trabalhar, essa linha ainda é limitada. Suas análises, muitas vezes, são inconclusivas porque dependem de melhores hipóteses para tentar analisar ${ }^{213}$. Prescindem, destarte, de melhores de modelos econométricos e especificações mais robustas - em resumo, de melhor teoria. A grande dificuldade enfrentada por esse tipo de análise é, realmente, a de apoiar-se na suposição da existência de uma direção de causalidade que, na maioria das vezes, parece ser dúbia. As correlações encontradas revelam padrões de ocorrência simultânea. Em vista dos parâmetros analisados, todavia, torna-se difícil concluir se são ou não os processos de integração que causariam crescimento econômico.

Por causa das insuficiências apontadas, uma terceira geração de estudos dá sinas de despontar no horizonte ${ }^{214}$. Em comum com as análises anteriores, apresentam as seguintes preocupações. Em primeiro lugar, concedem grande ênfase ao aspecto empírico: utilizam metodologias quantitativas sofisticadas e trabalham com grandes bancos de dados. Em segundo lugar, parecem dar destaque a aspectos institucionais. Em terceiro lugar, tratam a questão da abertura financeira como um abrangente conjunto de reformas, não se atendo a mera política de abertura da conta de capitais. Entretanto, existe ao menos uma grande diferença fundamental em relação aos estudos anteriores: a nova geração parece não confiar tanto no pressuposto de que a liberalização teria efeitos positivos. Nesse sentido, dá maior peso teórico às evidências de que liberalização financeira unilateral pode gerar instabilidade e agravar desequilíbrios internacionais, levando potencialmente a crise financeiras de grande repercussão. Além disso, não assume uma relação de causalidade direta entre reformas e abertura financeira, de um lado, e crescimento econômico e crise, de outro. Apenas tentam constatar a freqüência com que tais eventos ocorrem simultaneamente, muitas vezes sem incorrer em afirmações peremptórias sobre se crise ou crescimento são causas ou conseqüências do aparecimento de certas regras e regimes.

\footnotetext{
212 Vide, por exemplo, (Abiad, Detragiache, and Tressel 2008; Kose et al. 2006).

213 Vide, por exemplo, (E. S Prasad, Rajan, and A. Subramanian 2007).

214 (Stulz 2005; Rodrik and Arvind Subramanian 2009).
} 


\section{III.3. FormulaÇ̃̃o dO MODELO DE ANALítico.}

A análise a ser descrita e os modelos econométricos a serem explicitados infra dialogam, tanto com a literatura exposta acima, como com os capítulos anteriores. Para compreender processos de integração financeira, suas causas e efeitos, tentar-se-á medir o relacionamento entre certas variáveis institucionais bem determinadas (processos de integração financeira) e algumas variáveis econômicas pré-definidas. Trata-se, portanto, de análise empírica, cujo modelo analítico é inspirado em hipóteses extraídas de estudos recentes e da análise qualitativa referida em capítulos supra.

A intuição subjacente ao modelo é a seguinte. Se os mercados financeiros de dois países $\mathrm{P}_{\mathrm{i}}$ e $\mathrm{P}_{\mathrm{j}}$ se integram, certas variáveis econômicas chave passarão a se comportar de maneira semelhante, posto que supostamente sujeitas a influências parecidas. Ao contrário, quanto menos integrados são os mercados financeiros dos países $P_{i}$ e $P_{j}$, menos relacionado será o comportamento de variáveis chave - o comportamento delas será mais aleatório. Trata-se, portanto, de uma análise de convergência e divergência: o que se quer descobrir é quais processos de integração financeira estão relacionados a que processos de convergência/divergência de indicadores econômicos, e quais não estão. Os processos de integração a serem analisados serão de quatro tipos: (a) acordos de comércio de serviços financeiros, (b) acordos de mútuo reconhecimento, (c) acordos de harmonização, e (d) acordos de cooperação técnica.

Uma das inovações da presente análise é justamente verificar se é possível correlacionar instituições e regras jurídicas, criadas no ambiente externo a determinado par de países $\mathrm{P}_{\mathrm{i}}$ e $\mathrm{P}_{\mathrm{j}}$, e a integração dos mercados financeiros domésticos de ambos os países. Até o momento, outros estudos empíticos caminhavam para considerar apenas instituições e reformas financeiras domésticas e seu impactos em mercados domésticos.

Outro ponto a ser destacado é o relacionamento da presente análise com a terceira geração de estudos sobre globalização financeira mencionada supra, que são críticos do pressuposto de que liberalização levaria à globalização. De certo modo, trata-se aqui de estudar justamente a hipótese contrária à de que a globalização financeira é gerada pela destruição de instituições e regras domésticas. Em última instância, quer-se conhecer um pouco mais da relação entre a emergência de regras e instituições jurídicas internacionais 
e aumento da integração financeira - portanto, como mais regulação (internacional) gera maior integração.

Por último, nota-se que, a priori, quer-se evitar inferências relacionadas à direção da causalidade. Não se pressupõe aqui que processos de integração levam à convergência; tampouco que a convergência causa processos de integração. Analisa-se apenas a existência de maior ou menor correlação entre os fenômenos. Nesse sentido, pode-se dizer que se trata de estudo cujo valor é mais marcadamente explicativo do que normativo, e cuja tônica é a comparação entre processos de integração.

\section{III.3.1. VARIÁVEIS ECONÔMICAS.}

A unidade básica de análise será um par de países $P_{i}$ e $P_{j}$ e o conjunto de atributos de seu relacionamento. Quer-se verificar a força da correlação entre determinados tipos de acordo ou processo internacional de integração financeira (variáveis independentes) e a convergência de certas variáveis representativas dos mercados financeiros domésticos.

Foram escolhidos três tipos de variáveis econômicas: (1) variáveis macroeconômicas gerais (taxa de crescimento do PIB, taxa de inflação e taxa de câmbio); (2) indicadores de setoriais do mercado bancário (relação capital/ativos, taxas de juros, volume de crédito); (3) indicadores setoriais do mercado de capitais (investimento estrangeiro, capitalização número de empresas e volume de negócios em bolsa de valores).

\section{III.3.1.1. Variáveis macroeconômicas tradicionais.}

A primeira sub-hipótese a ser analisada é a de que existiria uma correlação entre os processos de integração financeira e a convergência de certas variáveis macroeconômicas que são relevantes para a economia e para o setor financeiro dos países envolvidos. As variáveis escolhidas para esse fim foram o Produto Interno Bruto (PIB), inflação medida pelo índice de preços ao consumidor, e taxa de câmbio.

\section{III.3.1.2. Indicadores setoriais bancários.}

A segunda sub-hipótese a ser analisada é a de que existiria uma correlação entre processos de integração financeira e a convergência de indicadores do setor bancário dos 
países envolvidos. As variáveis escolhidas foram a relação capital/ativos financeiros, taxas de juros para depósitos e para empréstimos, prêmio de risco, e crédito doméstico.

\section{III.3.1.3. Indicadores setoriais de mercado de capitais.}

A terceira sub-hipótese a ser analisada é a de que existiria uma correlação entre processos de integração financeira e a convergência de indicadores do setor de mercado de capitais dos países envolvidos. As variáveis escolhidas foram indicadores de investimento estrangeiro e financiamento internacional, movimentação de bolsa de valores, capitalização bursátil e desenvolvimento do mercado acionário.

\section{III.3.2. VARIÁVEIS de PROCESSOS DE INTEGRAÇÃo FINANCEIRA.}

O centro do presente estudo são os diferentes processos de integração financeira. Nos termos descritos nos capítulos anteriores, serão considerados cinco diferentes processos de integração financeira: (1) acordos de comércio envolvendo serviços financeiros, (2) acordos de harmonização regulatória financeira, (3) acordos de mútuo reconhecimento, e (4) acordo de cooperação regulatória.

Cada um dos processos mencionados têm estrutura e componentes específicos, servem a diferentes propósitos, são utilizados de forma diversa pelos governos nacionais, e geram conseqüências diferenciadas. São justamente essas idiossincrasias que se tentará explorar.

Em relação a cada um dos processos de integração arrolados identificam-se três modalidades principais: processos bilaterais, plurilaterais (regionais) e multilaterais. Além disso, tendo-se em vista que no âmbito da regulação financeira internacional ainda persiste uma divisão entre mercado bancário e mercado de capitais, faz-se importante separar acordos referentes a bancos e acordos referentes a bolsas de valores.

\section{III.3.2.1. Acordos de comércio.}

A inclusão de obrigações de abertura comercial para serviços financeiros em acordos de comércio é relativamente nova. As informação mais relevantes sobre acordos de comércio, portanto, são sua existência e data de entrada em vigor. Trata-se, assim, de variável binária que indica a entrada em vigor de acordo assinado entre dois ou mais 
países, uma dummy que assume o valor 1 a partir do ano em que o acordo passa a vigorar entre dois países.

Com base nos dados conseguidos junto à Organização Mundial de Comércio, levantaram-se informações sobre todos os acordos bilaterais, plurilaterais e multilaterais assinados e comunicados ao Sistema de Informação sobre Acordos Regionais ${ }^{215}$ da instituição.

${ }^{215}$ Vide Regional Trade Agreements Information System (RTA-IS),

http://rtais.wto.org/UI/PublicMaintainRTAHome.aspx. 


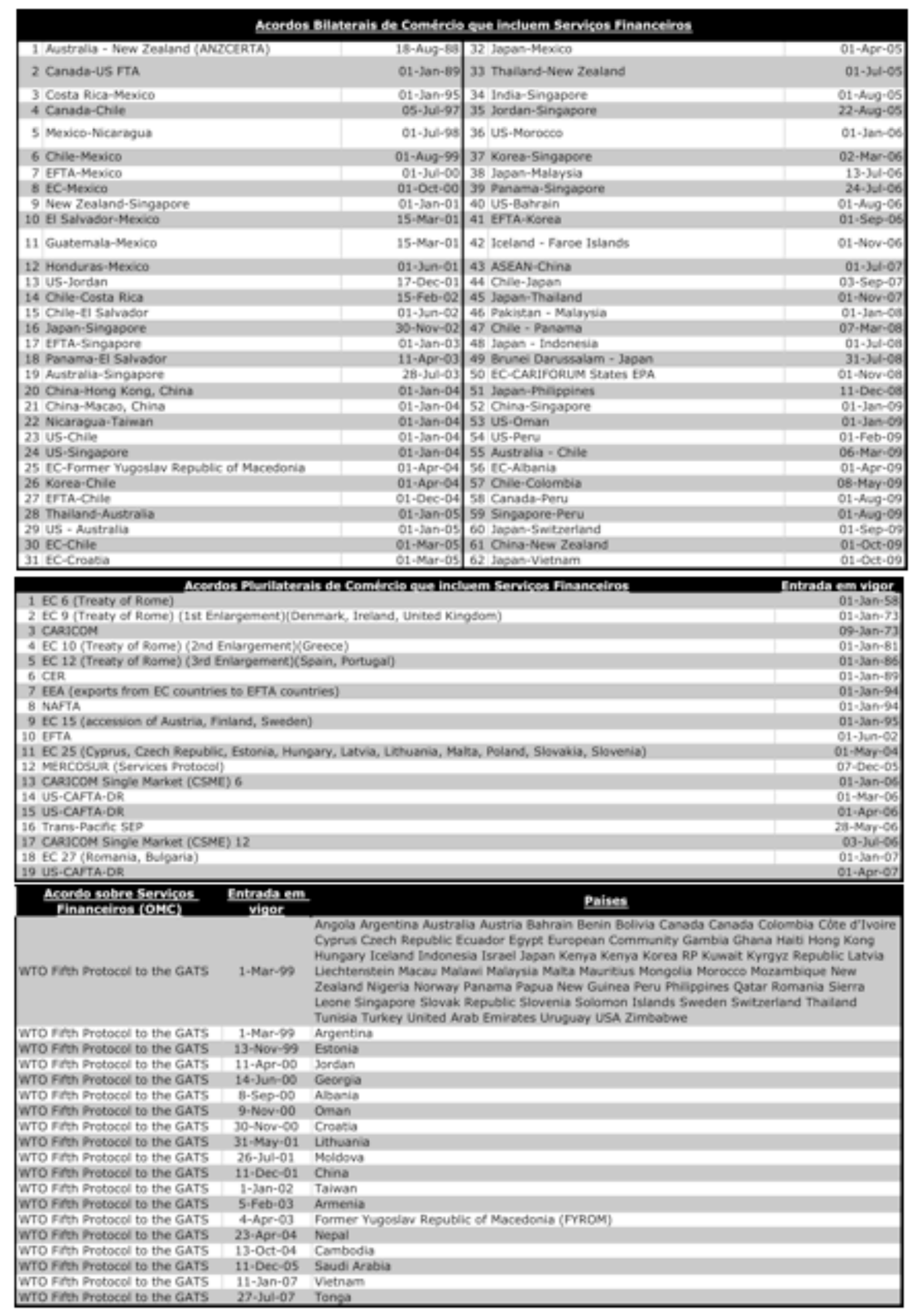


A figura abaixo e os quadros acima registram quais acordos foram encontrados e quando tais acordos entraram em vigor. Entre 1958 e 2009 registrou-se a entrada em vigor de 62 acordos bilaterais, 19 acordos plurilaterais e 1 acordo multilateral prevendo a liberalização do comércio de serviços financeiros, sendo que mais de $85 \%$ de tais acordos foram assinados após o ano 2000. Tais acordos foram analisados e classificados segundo o tipo (bilaterais, plurilaterais e multilaterais) o setor de abrangência (setor bancário ou setor de valores mobiliários).

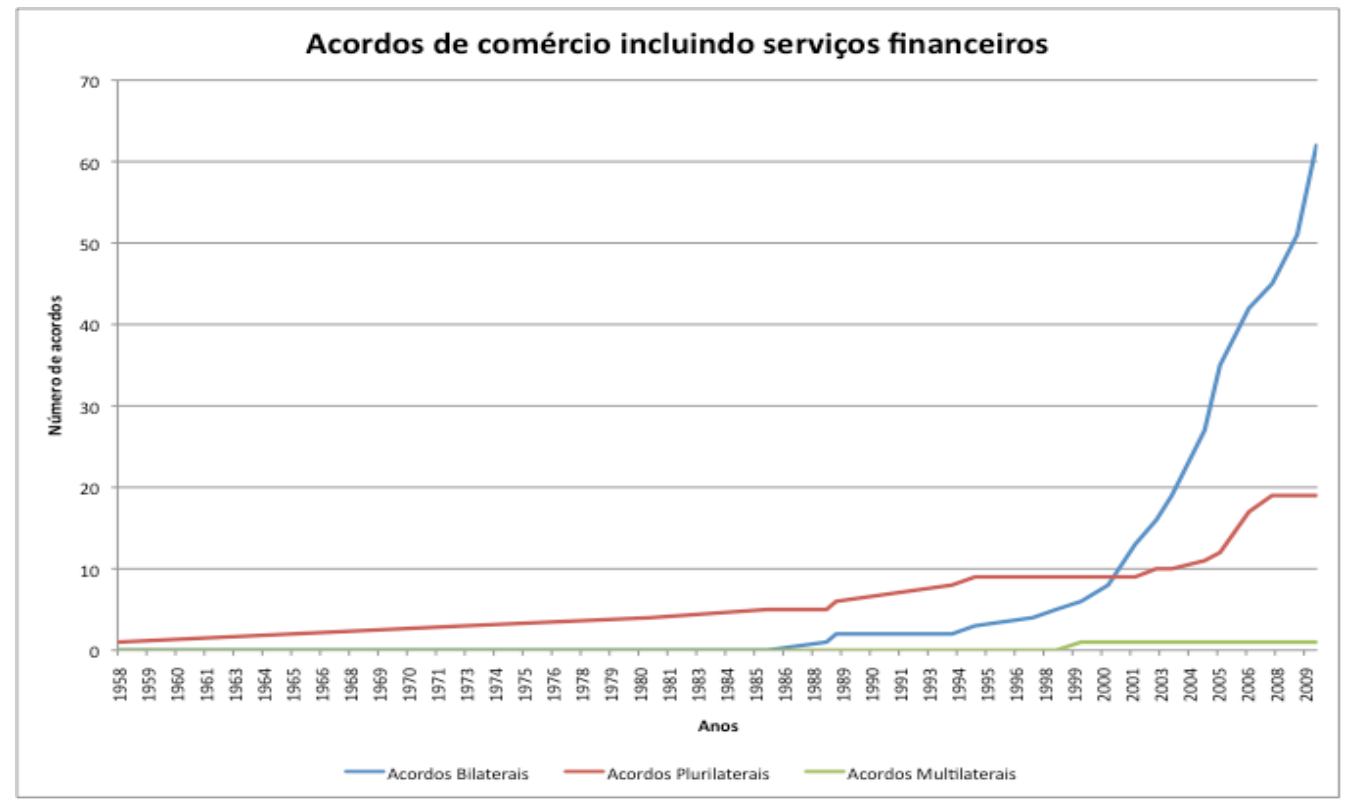

\section{III.3.2.2. Acordos de harmonização.}

Acordos internacionais com dispositivos que impliquem harmonização regulatória em matéria financeira são bastante sofisticados e extremamente difíceis de negociar. Isso os torna muitíssimo importantes e raros. Novamente, a informação mais relevante é sua existência e vigência. Trata-se, portanto, de variável binária (dummy) que indica a entrada em vigor de acordo assinado entre dois ou mais países. A tabela abaixo indica quais acordos foram encontrados a partir da literatura pesquisada. Os acordos foram classificados segundo seu tipo (bilaterais, plurilaterais e multilaterais) e setores de referência (bancário e mercado de capitais). 


\begin{tabular}{|l|c|c|}
\hline \multicolumn{2}{|l|}{ Acordos de Harmonização Regulatória } & Entrada em vigor \\
\hline 1 & Second Council Directive 89/646/EEC (Second Banking Directive) & 01 -Jan-93 \\
\hline $2 \begin{array}{l}\text { Second Council Directive 89/646/EEC (Second Banking Directive)(accession of } \\
\text { Austria, Finland, Sweden) }\end{array}$ & 01 -Jan-95 \\
\hline $3 \begin{array}{l}\text { Second Council Directive 89/646/EEC (Second Banking Directive)(Cyprus, Czech } \\
\text { Republic, Estonia, Hungary, Latvia, Lithuania, Malta, Poland, Slovakia, Slovenia) }\end{array}$ & 01 -May-04 \\
\hline $4 \begin{array}{l}\text { Second Council Directive 89/646/EEC (Second Banking Directive)(Romania, } \\
\text { Bulgaria) }\end{array}$ & 01 -Jan-07 \\
\hline $5 \begin{array}{l}\text { Multijurisdictional Disclosure and Modifications to the Current Registration and } \\
\text { Reporting System for Canadian Issuers (MJDS) }\end{array}$ & 01 -Jul-91 \\
\hline 6 & Capital Accord (Basel I) & 01 -Jan-88 \\
\hline 7 & Core Principles for Effective Banking Supervision & $01-S e p-97$ \\
\hline 8 & Objectives and Principles of Securities Regulation & 01 -Sep-98 \\
\hline 9 & Market in Financial Instruments Directive & 30 -Apr-04 \\
\hline
\end{tabular}

\section{III.3.3.3. Acordos de mútuo reconhecimento.}

De modo bastante similar aos acordos de harmonização regulatória, acordos internacionais com dispositivos de mútuo reconhecimento aplicados à matéria financeira são raros. Novamente, a informação mais relevante é sua existência e vigência, codificadas como variável binária que assume o valor 1 quando de sua data de entrada em vigor (dummy). A tabela abaixo indica quais acordos contendo provisões de harmonização regulatória foram encontrados a partir da literatura pesquisada.

\begin{tabular}{|l|l|c|}
\hline \multicolumn{2}{|l|}{ Acordos de Reconhecimento Mútuo } & Entrada em vigor \\
\hline 1 & $\begin{array}{l}\text { Australia - New Zealand (ANZCERTA) - Services protocol } \\
2\end{array}$ & $\begin{array}{l}\text { Multijurisdictional Disclosure and Modifications to the Current Registration and } \\
\text { Reporting System for Canadian Issuers (MJDS) }\end{array}$ \\
\hline 3 & US-Australia (Mutual Recognition in Securities Regulation) & 01 -Jul-91 \\
\hline 4 & WTO GATS & 25 -Aug-08 \\
\hline 5 & $\begin{array}{l}\text { First Council Directive 77/780/EEC (coordination of laws regulations and } \\
\text { administrative provisions) }\end{array}$ & 01 -Jan-95 \\
\hline 6 & Second Council Directive 89/646/EEC (Second Banking Directive) & 12 -Dec-77 \\
\hline 7 & Market in Financial Instruments Directive & 01 -Jan-93 \\
\hline
\end{tabular}

\section{III.3.3.5. Acordos de cooperação.}

Acordos de cooperação regulatória em matéria financeira têm normalmente natureza administrativa, não implicando, portanto, a assinatura de tratados internacionais. Do levantamento feito nota-se que tratam com regularidade de intercâmbio de informações, confidencialidade, cooperação técnica e facilitação de procedimentos investigativos, o que implica a criação de poucas obrigações legais stricto sensu. Tais 
acordos, principalmente na área de regulação de mercado de capitais, são muito mais freqüentes. Não foram encontrados registros públicos de acordos de cooperação entre autoridades regulatórias bancárias.

Novamente, a informação mais relevante é sua existência e vigência. Trata-se, portanto, de variável binária que indica a entrada em vigor de acordo assinado entre dois ou mais países. Com base nos dados disponíveis junto à Organização Internacional de Comissões de Valores Mobiliários (IOSCO), levantaram-se informações sobre todos os acordos assinados e comunicados ao registro global da instituição ${ }^{216}$. As figuras abaixo e tabelas anexas registram quais acordos foram encontrados e quando tais acordos entraram em vigor. Os acordos foram classificados segundo seu tipo (bilaterais, plurilaterais e multilaterais) e setores de referência (bancário e mercado de capitais). Entre 1982 e 2009 registrou-se a entrada em vigor de 383 acordos bilaterais, 1 acordo plurilateral e 1 acordo multilateral de natureza administrativa, prevendo a cooperação entre agências reguladoras de mercado de capitais.

\section{III.3.7.O MODELO.}

Com o modelo de análise, quer-se verificar a convergência de uma variável econômica medida em relação ao país $\mathrm{P}_{\mathrm{i}} \mathrm{e}$ uma variável econômica medida em relação ao país $P_{j}$ na presença de um processo de integração $I_{a}$ que foi estabelecido entre os países $\mathrm{P}_{\mathrm{I}, \mathrm{j}}$. Em vista dessa discussão, define-se o modelo econométrico a ser testado na seguinte forma:

$\mathrm{Z}_{i, t}=\alpha_{i}+\beta_{j} \mathrm{Z}_{j, t}+\sum_{a=1}^{A} \omega_{a} I_{a t}^{j}+\sum_{a=1}^{A} \hat{\omega_{a}} I_{a t}^{i j} \mathrm{Z}_{j, t}+\varepsilon_{i j t}$

em que:

$\mathrm{Z}_{i, t}=$ variável econômica dependente, medida em relação ao país $P_{i}$ no ano $t$; $\beta_{j} \mathrm{Z}_{j, t}=$ variáveis econômicas independentes, medida em relação ao pais $\mathrm{P}_{\mathrm{j}}$ no

ano $t$;

$\alpha_{i}=$ intercepto;

\footnotetext{
${ }^{216}$ Vide List of Bilateral MOUs signed by IOSCO members, http://www.iosco.org/library/index.cfm?section=mou.
} 
$\sum_{a=1}^{A} \omega_{a} I_{a t}^{j}=$ processos de integração financeira $\mathrm{I}_{\mathrm{a}}$ e seus coeficientes $\omega_{a} ;$

$\sum_{a=1}^{A} \hat{\omega}_{a} I_{a t}^{i j} \mathrm{Z}_{j, t}=$ processos de integração financeira $\mathrm{I}_{\mathrm{a}}$ interagidos com variável

econômica independente $Z_{\mathrm{j}}$, e seus coeficientes $\omega_{a}$;

$\varepsilon_{i j t}=$ resíduo.

O coeficiente que se quer ver estimado é $\omega_{a}$ de $I_{a t}^{i j} \mathrm{Z}_{j, t}$.

\section{III.4. DAdOS E METOdologiA.}

A unidade de análise escolhida são relacionamentos entre pares de países $\mathrm{P}_{\mathrm{ij}} \mathrm{e}$ seus predicados $Z_{i, j}$ e $I_{i j}$. Foram escolhidos 91 países, que, pareados, geraram 8.281 possibilidades de relacionamentos (91 x 91). A lista de países escolhidos segue abaixo. Em vista da assimetria constatada em diversos dos relacionamentos incluídos, foi necessário considerar que a relação $P_{i j}$ é diferente da relação $P_{\mathrm{ji}}$.

\begin{tabular}{|c|c|c|c|c|c|c|c|}
\hline \multicolumn{8}{|c|}{ Países } \\
\hline 1 & Albania & 25 & Egypt & 49 & Kyrgyz Republic & 73 & South Africa \\
\hline 2 & Algeria & 26 & El Salvador & 50 & Latvia & 74 & Spain \\
\hline 3 & Argentina & 27 & Estonia & 51 & Lithuania & 75 & Sri Lanka \\
\hline 4 & Australia & 28 & Ethiopia & 52 & Madagascar & 76 & Sweden \\
\hline 5 & Austria & 29 & Finland & 53 & Malaysia & 77 & Switzerland \\
\hline 6 & Azerbaijan & 30 & France & 54 & Mexico & 78 & Taiwan \\
\hline 7 & Bangladesh & 31 & Georgia & 55 & Morocco & 79 & Tanzania \\
\hline 8 & Belarus & 32 & West Germany & 56 & Mozambique & 80 & Thailand \\
\hline 9 & Belgium & 33 & Ghana & 57 & Nepal & 81 & Tunisia \\
\hline 10 & Bolivia & 34 & Greece & 58 & Netherlands & 82 & Turkey \\
\hline 11 & Brazil & 35 & Guatemala & 59 & New Zealand & 83 & Uganda \\
\hline 12 & Bulgaria & 36 & Hong Kong & 60 & Nicaragua & 84 & Ukraine \\
\hline 13 & Burkina-Faso & 37 & Hungary & 61 & Nigeria & 85 & United Kingdom \\
\hline 14 & Cameroon & 38 & India & 62 & Norway & 86 & United States \\
\hline 15 & Canada & 39 & Indonesia & 63 & Pakistan & 87 & Uruguay \\
\hline 16 & Chile & 40 & Ireland & 64 & Paraguay & 88 & Uzbekistan \\
\hline 17 & China & 41 & Israel & 65 & Peru & 89 & Venezuela \\
\hline 18 & Colombia & 42 & Italy & 66 & Philippines & 90 & Vietnam \\
\hline 19 & Costa Rica & 43 & Jamaica & 67 & Poland & 91 & Zimbabwe \\
\hline 20 & Côte dIvoire & 44 & Japan & 68 & Portugal & & \\
\hline 21 & Czech Republic & 45 & Jordan & 69 & Romania & & \\
\hline 22 & Denmark & 46 & Kazakhstan & 70 & Russia & & \\
\hline 23 & Dominican Republic & 47 & Kenya & 71 & Senegal & & \\
\hline 24 & Ecuador & 48 & Korea & 72 & Singapore & & \\
\hline
\end{tabular}

Os relacionamentos foram observados por um período de 36 anos iniciado em 1973 e terminado em 2008, o que gerou 298.116 entradas de dados (8.281 x 36). Em 
relação a cada entrada, buscaram-se 48 variáveis, dentre as quais 24 processos de integração e 31 econômicas.

\begin{tabular}{|c|c|c|c|c|}
\hline \multicolumn{2}{|r|}{ Economic Variables } & \multicolumn{3}{|r|}{ Financial Intergration Processes } \\
\hline 1 i_co 2000100 & Consumer price index $(2000=100)$ & & jxmablbk & Bilateral Trade Agreements - Banking \\
\hline 2 i_inflatio 1 & Inflation, consumer prices (annual \%) & 2 & $j \times r c m / b k$ & Plurilateral Trade Agreements - Banking \\
\hline 3 i_official ne & Official exchange rate (LCU per US\$, period average) & 3 & jxmablsc & Multilateral Trade Agreements - Banking \\
\hline 4 i_realeffe $\sim x$ & Real effective exchange rate index $(2000=100)$ & 4 & jxmaplsc & Bilateral Trade Agreements - Securities \\
\hline 5 i_tradeins $\sim p$ & Trade in services (\% of GDP) & 5 & jxrcplsc & Plurilateral Trade Agreements - Securities \\
\hline 6 i_gdpconst $\sim s$ & GDP (constant 2000 US\$) & 6 & jxrcm/sc & Multilateral Trade Agreements - Securities \\
\hline 7 i_gdpgrowt I & GDP growth (annual \%) & 7 & jxhmblbk & Bilateral Harmonization Agreements - Banking \\
\hline 8 i_gdpperca s & GDP per capita (constant 2000 US\$) & 8 & $j \times h m p l b k$ & Plurilateral Harmonization Agreements - Banking \\
\hline 9 i_gdpperca / & GDP per capita growth (annual \%) & 9 & jxhmplsc & Multilateral Harmonization Agreements - Banking \\
\hline 10 i_bankcapi o & Bank capital to assets ratio (\%) & 10 & $j \times h m m / s c$ & Bilateral Harmonization Agreements - Securities \\
\hline 11 i_banknonp r r & Bank nonperfoming loans to total gross loa & 11 & jxcoblbk & Plurilateral Harmonization Agreements - Securities \\
\hline 12 i_depositine & Deposit interest rate $(\%)$ & 12 & jxcoplbk & Multilateral Harmonization Agreements - Securities \\
\hline 13 i_lendingine & Lending interest rate (\%) & 13 & jxcomlbk & Bilateral Recognition Agreements - Banking \\
\hline 14 i_interest $\sim m$ & Interest rate spread (lending rate minus deposit rate, \%) & 14 & jxmaplbk & Plurilateral Recognition Agreements - Banking \\
\hline 15 i_realinte e & Real interest rate $(\%)$ & 15 & jxrcplbk & Multilateral Recognition Agreements - Banking \\
\hline 16 i_riskprem $\sim m$ & Risk premium on lending (prime rate minus treasury bill rate, $\%$ ) & 16 & $j \times h m m / b k$ & Bilateral Recognition Agreements - Securities \\
\hline 17 i_domestic n & Domestic credit provided by banking sector ( $\%$ of GDP) & 17 & jxcoblsc & Plurilateral Recognition Agreements - Securities \\
\hline 18 i_foreignd / & Foreign direct investment, net inflows ( $\%$ of GDP) & 18 & $j \times m a m / b k$ & Multilateral Recognition Agreements - Securities \\
\hline 19 i_foreignd f & Foreign direct investment, net outflows (\% of GDP) & 19 & jxmam/sc & Bilateral Cooperation Agreements - Banking \\
\hline 20 i_portfolinu & Portfolio investment, equity (DRS, current US\$) & 20 & jxrcblbk & Plurilateral Cooperation Agreements - Banking \\
\hline 21 j_portfoli c & Portfolio investment, excluding LCFAR (BoP, current US\$) & 21 & jxrcblsc & Multilateral Cooperation Agreements - Banking \\
\hline 22 i_financin $\sim t$ & Financing via international capital markets (gross, $\%$ of GDP) & 22 & $j \times h m b l s c$ & Bilateral Cooperation Agreements - Securities \\
\hline 23 i_listeddo / & Listed domestic companies, total & 23 & jxcop/sc & Plurilateral Cooperation Agreements - Securities \\
\hline 24 i_marketca o & Market capitalization of listed companies ( $\%$ of GDP) & 24 & $j \times c o m / s c$ & Multilateral Cooperation Agreements - Securities \\
\hline 25 i_marketca s & Market capitalization of listed companies (current US\$) & & & \\
\hline 26 i_netdomes u & Net domestic credit (current LCU) & & & \\
\hline 27 i_netforei u & Net foreign assets (current LCU) & & & \\
\hline 28 i_spglobal a & S\&P Global Equity Indices (annual \% change) & & & \\
\hline 29 j_stockstr $\sim p$ & Stocks traded, total value (\% of GDP) & & & \\
\hline 30 i_stockstr u u & Stocks traded, total value (current US\$) & & & \\
\hline 31 i_stockstr o & Stocks traded, turnover ratio (\%) & & & \\
\hline
\end{tabular}

\section{III.4.1. VARIÁVEIS ECONÔMICAS.}

A fonte primária das séries históricas das variáveis econômicas é o serviço estatístico do Fundo Monetário Internacional (FMI ${ }^{217}$. Utilizou-se o aplicativo de extração de informações do banco de dados Estatísticas Financeiras Internacionais ${ }^{218}$. Para cada um dos 91 países foram baixadas séries anuais (1973-2008) referentes a cada uma das variáveis escolhidas. Nem todas as séries estavam completas, o que reduziu o número de observações utilizáveis em cada série. No total, foram obtidas 5.695.417 observações. Abaixo segue um sumário estatístico dessas observações.

${ }^{217}$ Vide http://www.imf.org/external/data.htm.

${ }^{218}$ International Financial Statistics. Vide (Rodrik and Arvind Subramanian 2009). 


\begin{tabular}{|c|c|c|c|c|c|}
\hline Variável & Obs & Média & Desvio Padrão & Min & Max \\
\hline i_co 2000100 & 255073 & $158 . \overline{5173}$ & 5538.402 & $4.49 \bar{E}-10$ & 293318 \\
\hline i_inflatio / & 252798 & 47.79935 & 562.8376 & -13.84541 & 24411.03 \\
\hline i_official e & 266630 & 259.3059 & 1317.639 & $2.23 \mathrm{E}-12$ & 16302.25 \\
\hline i_realeffe $\sim x$ & 149331 & 3654.312 & 114881.3 & 20.76 & 4617941 \\
\hline$i$ tradeins $\sim p$ & 236873 & 14.57572 & 10.72924 & 0.9823381 & 89.77061 \\
\hline i_gdpconst $\sim s$ & 271089 & $2.88 \mathrm{E}+11$ & $9.72 E+11$ & 829000000 & $1.16 \mathrm{E}+13$ \\
\hline i_gdpgrowt / & 270452 & 3.509021 & 4.790957 & -44.9 & 34.5 \\
\hline i_gdpperca s & 271089 & 7037.552 & 9146.16 & 102.286 & 42683.59 \\
\hline i_gdpperca / & 270543 & 2.006935 & 4.691038 & -44.0663 & 33.03049 \\
\hline i_bankcapi o & 52507 & 8.635875 & 3.525142 & 2.6 & 30.5 \\
\hline i_banknonp r & 53872 & 7.647128 & 7.661826 & 0.2 & 34.9 \\
\hline i_depositi e & 203203 & 85.3925 & 2317.188 & 0.01 & 107379.1 \\
\hline i_lendingine & 189280 & 82.90851 & 2674.366 & 1.664833 & 121906 \\
\hline i_interest m & 176358 & 17.28251 & 335.9603 & -1027.885 & 14526.86 \\
\hline i_realinte e & 186186 & 5.976095 & 22.22795 & -97.81207 & 789.799 \\
\hline i_riskprem m & 105924 & 6.815589 & 24.99359 & -19.80833 & 605.7333 \\
\hline i_domestic $n$ & 254709 & 64.94358 & 48.34186 & -12.42665 & 312.7838 \\
\hline i_foreignd I & 245154 & 2.233262 & 4.066299 & -15.1032 & 92.67347 \\
\hline i_foreignd ff & 178906 & 1.363883 & 4.00077 & -5.02957 & 89.45302 \\
\hline i_portfoli u & 271089 & 1930000000 & 12100000000 & -98100000000 & $1.98 \mathrm{E}+11$ \\
\hline i_portfoli $\sim$ C & 196651 & 3130000000 & 43100000000 & $-2.93 E+11$ & $8.51 E+11$ \\
\hline i_financin $\sim t$ & 28756 & 3.399976 & 4.429634 & 0 & 29.24664 \\
\hline i_listeddo / & 130312 & 559.7877 & 1152.923 & 2 & 8851 \\
\hline i_marketca o & 128583 & 49.20145 & 60.043 & 0.0041374 & 561.439 \\
\hline i_marketca u & 128765 & $3.83 E+11$ & $1.55 \mathrm{E}+12$ & 2000000 & $1.99 E+13$ \\
\hline i_netdomes u & 257803 & $2.87 E+14$ & $1.4 \mathrm{E}+16$ & $-1.4 \mathrm{E}+12$ & $7.47 E+17$ \\
\hline i_netforei u & 258440 & $4.05 E+12$ & $5.69 E+13$ & $-3.16 E+13$ & $2.69 E+15$ \\
\hline i_spglobal a & 49595 & 14.92678 & 62.20289 & -84.23 & 912.2813 \\
\hline i_stockstr p p & 126399 & 31.0038 & 53.01717 & 0 & 442.7917 \\
\hline i_stockstr u & 126581 & $4.39 \mathrm{E}+11$ & $2.55 \mathrm{E}+12$ & 0 & $4.26 E+13$ \\
\hline i_stockstr $\sim 0$ & 102466 & 54.17349 & 60.0736 & 0 & 497.38 \\
\hline
\end{tabular}

\section{III.4.2. ProceSSOS DE INTEGRAÇÃo.}

Os dados sobre acordos internacionais de integração financeira são basicamente dummies - variáveis que assumem o valor "0" (zero) quando inexistir acordo internacional entre dois países $\mathrm{P}_{\mathrm{i}}$ e $\mathrm{P}_{\mathrm{j}}$, e " 1 " (um) quando existir.

As séries históricas sobre acordos internacionais são não existiam anteriormente. São produtos da elaboração do autor. Para compilá-las, foi necessário, em primeiro lugar, identificar o conjunto de acordos internacionais referidos nos anexos infra.

A lista de acordos sobre serviços financeiros é uma derivação dos dados disponíveis junto à $\mathrm{OMC}$, conforme referido acima. A referida organização internacional mantém um banco de dados com informações sobre assinatura de acordos plurilaterais e bilaterais notificados nos termos do Artigo XXV do GATT e V do GATS ao Secretariado, e com informações sobre acordos multilaterais assinados em seu âmbito. $\mathrm{O}$ texto de tais acordos teve que ser explorado para verificar a existência de compromissos 
sobre serviços financeiros e classificá-los segundo o setor a que se referem - bancário ou mercado de capitais. As datas de vigência e membros iniciais foram pacientemente catalogados, assim como eventuais acessões posteriores. Foi dada atenção especial à ampliação e transformação das Comunidades Européias em União Européia, e à situação dos países que acederam mais tardiamente à OMC. Acordos entre blocos comerciais e países individuais foram analisados, e, em vista do conteúdo de suas obrigações e estrutura jurídica geralmente utilizada, foi decidido classificá-los como sendo bilaterais.

As listas de acordos de mútuo reconhecimento e de acordos de harmonização regulatória são produtos da consulta de extensa bibliografia ${ }^{219}$. Os principal dispositivo multilateral de harmonização considerado foi o primeiro Acordo da Basiléia (no caso do setor bancário). Não foi encontrado nenhum acordo semelhante para o setor de mercado de capitais $^{220}$. Sobre mútuo reconhecimento, foi considerado que a cláusula de mútuo reconhecimento constante do GATS (no caso de serviços financeiros em geral) serve a este fim. Sobre acordos plurilaterais, novamente normas da União Européia foram preocupações principais. Considerou-se que a Segunda Diretiva Bancária (para o setor bancário) e a Diretiva sobre Mercados de Instrumentos Financeiros (MiFID) (para o setor de mercado de capitais) foram os marcos europeus. Outros processos plurilaterais também foram analisados ${ }^{221}$, buscando-se informações sobre conteúdo de suas obrigações, setor de referência, data de entrada em vigor, membros iniciais e acessões. $\mathrm{O}$ mesmo aconteceu com os poucos casos de acordos bilaterais e mútuo reconhecimento (não foi encontrado nenhum caso de harmonização bilateral via acordo).

Não foram encontrados registros confiáveis de acordos de cooperação bancária. Quanto à cooperação em matéria de valores mobiliários e bolsas, no nível multilateral o

\footnotetext{
${ }^{219}$ Vide (Tarullo 2008; Bank of International Settlements 2006; Barth, Caprio, and R. Levine 2004; Basel Committee on Banking Supervision 1983; Basel Committee on Banking Supervision 1992; Basle Committee on Banking Supervision (BCBS) 1988; Chey 2007; Claessens, Underhill, and Zhang 2008; Demirguc-Kunt and Detragiache 2009; Ethan Barnaby Kapstein 1992; Goldberg 2009; Goldstein 2000; Gup 2004; Ho 2002; Tan Chong Lee 1989; Scott 2008; Simmons 2006a; Singer 2004; Singer 2007; Tarbert 2000; Kalemli-Ozcan, Papaioannou, and Peydró 2009; de Bruijn, Kox, and Lejour 2008; Barry Eichengreen 2008a; Kasman, Kirbaskasman, and Turgutlu 2008; Amurgo Pacheco 2007; Buonanno 2006; Adrian Richardson - RMIT Publishing - RMIT Training PTY LTD (http://www. rmitpublishing.com.au) 2006; Trachtman 2006; Demirguc-Kunt, Detragiache, and Tressel 2006; Scott 2005; Productivity Commission 2004; Shaffer 2002; Simmons 2001; Benink 1999; White 1996).

${ }^{220}$ Existem interessantes estudos comparando a emergência de regras harmonizadas sobre requisitos mínimos de capital para bancos e a ausência delas para bolsas de valores. Vide, por exemplo, (Singer 2007). ${ }^{221}$ Vide lista supra.
} 
principal acordo reconhecido é o Memorando de Entendimento Multilateral. Existe também um Memorando de Entendimento de natureza plurilateral no âmbito europeu. Todavia, a esmagadora maioria dos acordos levantados é de natureza bilateral.

As informações foram transladas para um banco de dados que indica quais pares de países $\mathrm{P}_{\mathrm{A}}-\mathrm{P}_{\mathrm{B}}$ fazem parte do mesmo acordo bilateral, plurilateral e multilateral, e em que ano tal acordo entrou em vigor. No total, foram obtidas 7.154.784 observações. Abaixo segue um sumário estatístico dessas observações.

\begin{tabular}{|c|c|c|c|c|c|}
\hline Variável & Observações & Média & Desvio Padrão & Min & $\operatorname{Max}$ \\
\hline mablbk & 298116 & 0.0194958 & 0.1382597 & 0 & 1 \\
\hline maplbk & 298116 & 0.0297804 & 0.1699811 & 0 & 1 \\
\hline mamlbk & 298116 & 0.1367253 & 0.3435577 & 0 & 1 \\
\hline mablsc & 298116 & 0.0194958 & 0.1382597 & 0 & 1 \\
\hline map/sc & 298116 & 0.0297804 & 0.1699811 & 0 & 1 \\
\hline mamlsc & 298116 & 0.1478351 & 0.354937 & 0 & 1 \\
\hline rcblbk & 298116 & 0.0111299 & 0.1049098 & 0 & 1 \\
\hline rcplbk & 298116 & 0.0235948 & 0.1517834 & 0 & 1 \\
\hline rcm/bk & 298116 & 0.2867743 & 0.452256 & 0 & 1 \\
\hline rcblsc & 298116 & 0.0112574 & 0.105502 & 0 & 1 \\
\hline rcplsc & 298116 & 0.010989 & 0.1042511 & 0 & 1 \\
\hline $\mathrm{rcm} / \mathrm{sc}$ & 298116 & 0.2867743 & 0.452256 & 0 & 1 \\
\hline$h m b l b k$ & 298116 & 0.010989 & 0.1042511 & 0 & 1 \\
\hline hmplbk & 298116 & 0.0235948 & 0.1517834 & 0 & 1 \\
\hline$h m m / b k$ & 298116 & 0.478022 & 0.4995176 & 0 & 1 \\
\hline$h m b / s c$ & 298116 & 0.0111098 & 0.1048159 & 0 & 1 \\
\hline hmplsc & 298116 & 0.010989 & 0.1042511 & 0 & 1 \\
\hline $\mathrm{hmm} / \mathrm{sc}$ & 298116 & 0.010989 & 0.1042511 & 0 & 1 \\
\hline coblbk & 298116 & 0.010989 & 0.1042511 & 0 & 1 \\
\hline coplbk & 298116 & 0.010989 & 0.1042511 & 0 & 1 \\
\hline comlbk & 298116 & 0.010989 & 0.1042511 & 0 & 1 \\
\hline coblsc & 298116 & 0.0357747 & 0.1857282 & 0 & 1 \\
\hline coplsc & 298116 & 0.010989 & 0.1042511 & 0 & 1 \\
\hline com/sc & 298116 & 0.0494975 & 0.2169047 & 0 & 1 \\
\hline
\end{tabular}

\section{III.4.3. TÉCNICA ECONOMÉTRICA.}

Para realizar as estimações, utilizaram-se técnicas de análise de dados longitudinais, também chamadas técnicas de painel. Foi empregado um modelo linear com efeitos aleatórios (xtreg re). Trata-se de estimador de método generalizado de momentos (GMM - Generalized Method of Moments), que é uma média ponderada por matriz dentre e entre (within and between) estimadores. 


\section{III.5. RESULTADOS.}

Inicialmente procedeu-se com um teste do colinearidade. Descartou-se as séries em que foi detectada colinearidade. Tal resultado apareceu principalmente em relação a séries de acordos de reconhecimento e de harmonização na modalidade plurilateral e bilateral. Nota-se que essa ocorrência era previsível tendo em vista que, principalmente em casos envolvendo a União Européia, um mesmo acordo integra elementos de harmonização e reconhecimento, o que torna difícil separar os efeitos de cada tipo de acordo. Também foi notada a ocorrência de colinearidade entre os acordos de comércio em relação às séries que abrangiam mercados bancários e as séries que abrangiam mercados de capitais, principalmente nas modalidades plurilateral e bilateral. Isso também era previsível posto que os acordos plurilaterais e bilaterais nesses casos, por serem bastante abrangentes, prevêem abertura generalizada para os dois setores. É, destarte, igualmente difícil separar os efeitos para ambos os setores bancários e de mercado de capitais. Também foram descartadas séries muito estáveis, como em situações em que não foram encontrados nenhum processo de integração. Esse foi o caso, por exemplo, dos acordos de harmonização bilateral e cooperação bilateral, plurilateral e multilateral para o setor bancário.

Os resultados completos das regressões encontram-se nos quadros anexos. Para facilitar a interpretação dos resultados, lembra-se que o coeficiente que se quer ver estimado é $\omega_{a}$ de todas as variáveis $\mathrm{Z}_{j, t}$ interagidas com os acordos $I_{a t}^{i j}$. Para auxiliar na compreensão dos anexos, preparou-se o quadro abaixo. As células preenchidas com a expressão "ns" indicam que os coeficientes encontrados não foram considerados estatisticamente significantes. A notação “_“ (sinal de negativo) implica dizer que foi encontrada uma correlação estatisticamente significante e negativa entre a variável econômica dependente $\mathrm{Z}_{i, t}$ e a variável econômica independente $\mathrm{Z}_{j, t}$ interagida com todos os acordos $I_{a t}^{i j}$. A notação “+” (sinal de positivo) indica que foi encontrada correlação estatisticamente significante e positiva. Em outras palavras, "+” quer dizer que o processo de integração está correlacionado com uma convergência entre as variáveis econômicas, e “_“" quer dizer que o processo de integração está correlacionado com uma divergência entre as variáveis econômicas. 


\begin{tabular}{|c|c|c|c|c|c|c|c|c|c|c|c|c|c|c|}
\hline Variable & jxmablbk & jxmaplbk & jxmamlbk & jxmamlsc & jxrcblbk & jxrcplbk & jercmlbk & jxrcblsc & jxrcplsc ; & jxhmplbk & jxhmmlbk & jxhmblsc & jxcoblsc & jxcomlsc \\
\hline $\begin{array}{l}\text { Consumer price index }(2000= \\
100)\end{array}$ & ns & ns & ns & ns & ns & sd & ns & ns & ns & [dropped] & ns & ns & sd & ns \\
\hline $2 \begin{array}{l}\text { Inflation, consumer prices (annual } \\
\% \text { ) }\end{array}$ & [dropped] & ns & ns & ns & ns & [dropped] & ns & ns & ns & ns & ns & ns & ns & ns \\
\hline $\begin{array}{l}\text { Official exchange rate (LCU per } \\
\text { US\$, period average) }\end{array}$ & + & ns & sd & - & [dropped] & ns & - & ns & [dropped] & [dropped] & - & [dropped] & ns & ns \\
\hline $\begin{array}{l}4 \begin{array}{l}\text { Real effective exchange rate } \\
\text { index }(2000=100)\end{array}\end{array}$ & ns & ns & ns & ns & ns & ns & ns & ns & [dropped] & [dropped] & ns & ns & ns & ns \\
\hline 5 Trade in services (\% of GDP) & - & ns & ns & ns & ns & - & - & $\mathrm{ns}$ & + & [dropped] & + & ns & - & $\mathrm{ns}$ \\
\hline 6 GDP (constant 2000 US\$) & - & ns & ns & - & ns & - & ns & - & + & [dropped] & - & ns & + & ns \\
\hline 7 GDP growth (annual \%) & - & + & ns & + & ns & ns & - & ns & ns & [dropped] & + & sd & + & ns \\
\hline $\boldsymbol{8} \begin{array}{l}\text { GDP per capita (constant } 2000 \\
\text { US } \$ \text { ) }\end{array}$ & - & ns & - & - & ns & + & ns & - & + & [dropped] & - & ns & + & ns \\
\hline 9 GDP per capita growth (annual & - & + & ns & ns & ns & + & - & ns & [dropped] & [dropped] & + & ns & + & ns \\
\hline 10 Bank capital to assets ratio (\%) & [dropped] & + & ns & ns & + & [dropped] & + & ns & [dropped] & - & [dropped] & [dropped] & ns & ns \\
\hline $\begin{array}{l}11 \text { Bank nonperfoming loans to total } \\
\text { gross loans }(\%)\end{array}$ & ns & ns & - & - & ns & ns & - & ns & [dropped] & [dropped] & [dropped] & [dropped] & ns & ns \\
\hline 12 Deposit interest rate (\%) & ns & ns & ns & ns & ns & ns & ns & [dropped] & ns & [dropped] & ns & [dropped] & ns & ns \\
\hline 13 Lending interest rate (\%) & ns & ns & ns & ns & ns & ns & ns & ns & ns & [dropped] & ns & ns & ns & ns \\
\hline $14 \begin{array}{l}\text { Interest rate spread (lending rate } \\
\text { minus deposit rate, \%) }\end{array}$ & ns & ns & ns & ns & ns & [dropped] & ns & [dropped] & [dropped] & ns & ns & [dropped] & ns & ns \\
\hline 15 Real interest rate (\%) & ns & ns & ns & ns & ns & ns & ns & [dropped] & [dropped] & [dropped] & + & ns & + & ns \\
\hline $16 \begin{array}{l}\text { Risk premium on lending (prime } \\
\text { rate minus treasury bill rate, \%) }\end{array}$ & ns & ns & - & + & ns & ns & ns & ns & [dropped] & [dropped] & ns & ns & ns & ns \\
\hline $17 \begin{array}{l}\text { Domestic credit provided by } \\
\text { banking sector (\% of GDP) }\end{array}$ & ns & - & ns & ns & ns & + & ns & ns & ns & [dropped] & ns & ns & + & sd \\
\hline $\begin{array}{l}18 \text { Foreign direct investment, net } \\
\text { inflows (\% of GDP) }\end{array}$ & - & + & ns & ns & ns & - & ns & ns & - & [dropped] & ns & [dropped] & - & + \\
\hline $\begin{array}{l}19 \begin{array}{l}\text { Foreign direct investment, net } \\
\text { outflows (\% of GDP) }\end{array}\end{array}$ & - & ns & ns & ns & ns & ns & + & $\mathrm{mr}$ & $\mathrm{mr}$ & [dropped] & - & ns & + & + \\
\hline $20 \begin{array}{l}\text { Portfolio investment, equity (DRS, } \\
\text { current US } \$ \text { ) }\end{array}$ & - & ns & ns & ns & ns & ns & + & - & + & [dropped] & - & [dropped] & + & + \\
\hline $\begin{array}{l}21 \text { Portfolio investment, excluding } \\
\text { LCFAR (BoP, current US\$) }\end{array}$ & ns & ns & ns & ns & ns & ns & ns & - & + & [dropped] & ns & + & - & ns \\
\hline $22 \begin{array}{l}\text { Financing via international capital } \\
\text { markets (gross, \% of GDP) }\end{array}$ & ns & sd & ns & ns & + & ns & + & [dropped] & [dropped] & [dropped] & [dropped] & [dropped] & ns & ns \\
\hline 23 Listed domestic companies, total & ns & + & ns & ns & - & - & ns & + & + & [dropped] & ns & - & ns & ns \\
\hline $\begin{array}{l}24 \\
\text { Market capitalization of listed } \\
\text { companies (\% of GDP) }\end{array}$ & + & ns & - & ns & ns & + & - & ns & ns & [dropped] & - & ns & + & + \\
\hline $\begin{array}{l}25 \\
\text { Market capitalization of listed } \\
\text { companies (current US\$) }\end{array}$ & - & ns & ns & ns & ns & [dropped] & - & ns & + & ns & - & ns & + & + \\
\hline 26 Net domestic credit (current $L C U$ ) & ns & ns & ns & ns & ns & ns & ns & ns & [dropped] & [dropped] & ns & [dropped] & ns & ns \\
\hline 27 Net foreign assets (current $L C U$ ) & + & ns & ns & ns & ns & ns & - & ns & ns & [dropped] & ns & ns & - & ns \\
\hline $\begin{array}{l}28 \text { S\&P Global Equity Indices (annual } \\
\% \text { change) }\end{array}$ & + & ns & - & ns & ns & ns & - & [dropped] & [dropped] & [dropped] & [dropped] & [dropped] & + & + \\
\hline $29 \begin{array}{l}\text { Stocks traded, total value (\% of } \\
\text { GDP) }\end{array}$ & - & - & ns & - & ns & + & ns & - & + & [dropped] & - & + & + & + \\
\hline $30 \begin{array}{l}\text { Stocks traded, total value } \\
\text { (current US\$) }\end{array}$ & - & ns & ns & - & ns & ns & ns & - & + & [dropped] & - & + & + & ns \\
\hline 31 Stocks traded, turnover ratio (\%) & ns & + & ns & + & ns & + & + & ns & ns & [dropped] & ns & ns & + & + \\
\hline
\end{tabular}

\section{III.5.1. ACORDOS DE COMÉRCIO.}

\section{III.5.1.1. Acordos Bilaterais.}

A tabela abaixo resume os resultados. Foi encontrada correlação positiva entre a existência de acordo bilateral de comércio de serviços bancários e taxa de câmbio oficial, capitalização de mercado de companhias listadas em bolsa, ativos estrangeiros líquidos e índices S\&P.

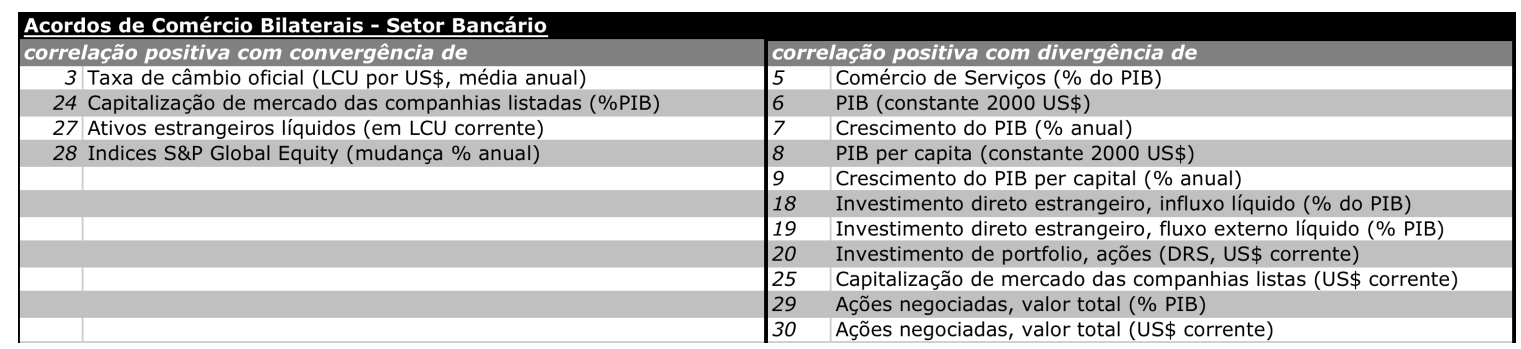


Nota-se que as variáveis econômicas que convergem são poucas e marcadamente relativas a mercado de capitais. Faz-se necessário lembrar que este se trata de caso em que a série relativa ao setor de mercado de capitais havia sido descartada devido à alta colinearidade com a do setor bancário.

É perceptível também que em diversos casos a assinatura de tais acordos está correlacionada à divergência nas variáveis econômicas, principalmente as macroeconômicas: comércio de serviços, PIB (valor, crescimento e per capita), investimento estrangeiro (influxo e saídas). Uma hipótese que explicaria essa correlação negativa é a existência de uma relação de complementaridade entre as economias envolvidas. É, assim, mais provável que surjam acordos bilaterais de comércio em serviços financeiros quando a interdependência entre duas economias é grande. Não se faz especulações sobre a direção da causalidade, lembra-se. Essa hipótese é especialmente atrativa em relação aos fluxos de investimento e fluxos de comércio. Todavia, essa hipótese é menos satisfatória em relação aos dados de PIB. Nesse caso, uma outra hipótese para explicar tal correlação negativa é a existência de uma relação de dependência unilateral ou vulnerabilidade entre as economias envolvidas. Acordos bilaterais de comércio entraram em vigor, assim, quando uma das economias se tornasse vulnerável economicamente por causa da queda de seu PIB. Nesse caso, a outra economia, mais pujante, teria condições de obter condições privilegiadas de acesso ao mercado da outra.

\section{III.5.1.2. Acordos Plurilaterais.}

Em relação aos acordos plurilaterais, novamente a série sobre o setor de mercado de capitais teve que ser descartada devido à colinearidade com a série referente ao setor bancário. Foi encontrada correlação estatisticamente relevante de acordos plurilaterais envolvendo comércio de serviços bancários com convergência de crescimento do PIB (nível e per capita), relação capital/ativos bancários, investimento direto estrangeiro e movimento em bolsa de valores (companhias listadas e ações negociadas). 


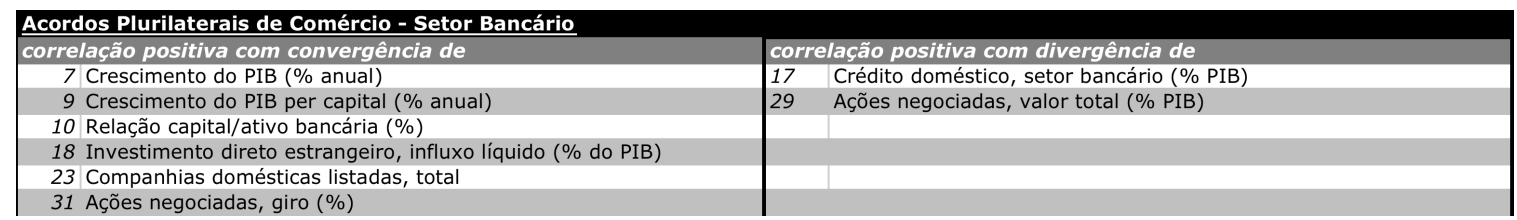

Tais correlações positivas parecem evidenciar um processo mais homogêneo de integração que não seria passível de ser relacionado, seja com relações de dependência, ou relações de vulnerabilidade.

\section{III.5.1.3. Acordos Multilaterais.}

Os acordos multilaterais de comércio em serviços financeiros parecem ser os mais heterogêneos. A evidência de convergência parece ser bastante menos substanciosa do que nas duas modalidades de acordo anteriores.

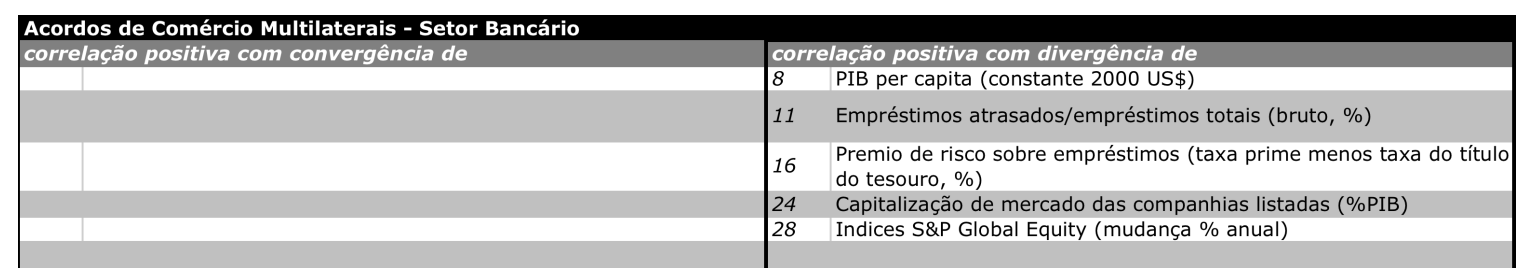

Em verdade, em ambos os setores bancário e de mercado de capitais, a evidência de correlações negativas (divergência) entre as variáveis econômicas e a assinatura de acordos parece ter mais peso. Isso fortalece a hipótese de dependência ou vulnerabilidade. A probabilidade de que dois países $P_{i}$ e $P_{j}$ participarão de um acordo de comércio multilateral de serviços financeiros parece aumentar quando as macroeconomias têm sinais inversos (PIB de $\mathrm{P}_{\mathrm{i}}$ acelera e taxa de câmbio valoriza, e, PIB de $\mathrm{P}_{\mathrm{j}}$ desacelera e taxa de câmbio desvaloriza, ou vice-versa), o setor bancário dos dois países andam em direções opostas (em $\mathrm{P}_{\mathrm{i}}$ a taxa de empréstimos atrasados aumenta e o prêmio de risco sobe, em $\mathrm{P}_{\mathrm{j}}$ a inadimplência diminui e o prêmio cai, ou vice-versa), e os mercados acionários descolam-se (capitalização bursátil, ações negociadas e índice de bolsa de valores sobe em $\mathrm{P}_{\mathrm{i}}$ e decresce em $\mathrm{P}_{\mathrm{j}}$, e vice-versa). 


\begin{tabular}{|c|c|}
\hline correlação positiva com convergência de & correlação positiva com divergência de \\
\hline 7 Crescimento do PIB (\% anual) & Taxa de câmbio oficial (LCU por US\$, média anual) \\
\hline $\begin{array}{l}16 \text { Premio de risco sobre empréstimos (taxa prime menos taxa do título } \\
\text { do tesouro, \%) }\end{array}$ & PIB (constante 2000 US\$) \\
\hline 31 Ações negociadas, giro (\%) & PIB per capita (constante 2000 US\$) \\
\hline & Empréstimos atrasados/empréstimos totais (bruto, \%) \\
\hline & Ações negociadas, valor total (\% PIB) \\
\hline & Ações negociadas, valor total (US\$ corrente) \\
\hline
\end{tabular}

De fato, a evidência de correlação negativa segue em linha com os relatos sobre o contexto de crise de mercados emergentes (Ásia e América Latina) e estabilidade em mercados desenvolvidos que foram referidos no capítulo anterior em relação à conclusão do Acordo sobre Serviços Financeiros da OMC.

\section{III.5.2. ACORDOS DE RECONHECIMENTO.}

\section{III.5.2.1. Acordos Bilaterais.}

Em relação aos acordos bilaterais de reconhecimento, a evidência em relação ao setor bancário parece diferir da em relação ao setor de mercado de capitais.

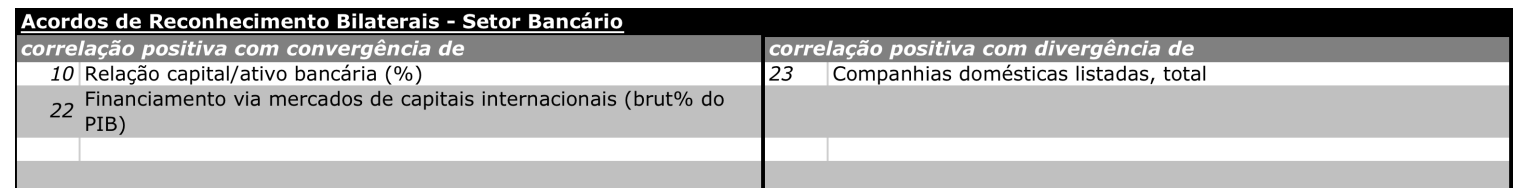

No setor bancário a entrada em vigor de acordos parece estar correlacionada com aumento da convergência da relação capital/ativo bancário e do nível de financiamento via mercados de capitais internacionais.

\begin{tabular}{l} 
Acordos de Reconhecimento Bilaterais - Mercado de Capitais \\
\begin{tabular}{|c|l|l|}
\hline correlação positiva com convergência de & \multicolumn{2}{|l|}{ correlação positiva com divergência de } \\
\hline 23 Companhias domésticas listadas, total & 6 & PIB (constante 2000 US\$) \\
& 8 & PIB per capita (constante 2000 US\$) \\
& 20 & Investimento de portfolio, ações (DRS, US\$ corrente) \\
& 21 & Portfolio investment, excluding LCFAR (BoP, current US $\$$ ) \\
& 29 & Ações negociadas, valor total (\% PIB) \\
30 & Ações negociadas, valor total (US\$ corrente)
\end{tabular} \\
\hline
\end{tabular}

Já no setor de mercado de capitais, as relações de divergência são mais importantes. Países entre os quais acordos de reconhecimento mútuo em matéria de 
valores mobiliários parecem ser características heterogêneas, ao menos em relação a PIB e mercado de capitais.

\section{III.5.2.2. Acordos Plurilaterais.}

Acordos plurilaterais de reconhecimento, todavia, apresentam uma figura completamente diferente dos acordos bilaterais. A evidência empírica parece mostrar que há grande correlação positiva entre a entrada em vigor de tais acordos e a convergência de diversas variáveis econômicas.

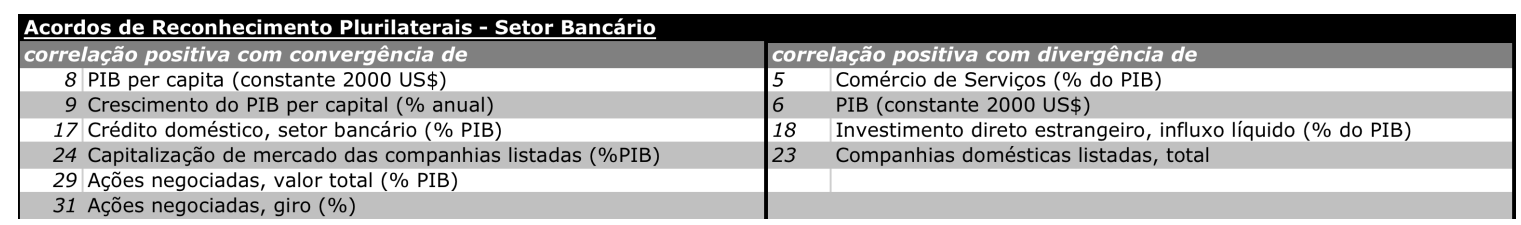

No que tange o setor bancário, a convergência de variáveis macroeconômicas como indicadores de PIB e o indicador de crédito bancário doméstico parece estar correlacionada com a assinatura dos acordos de reconhecimento. Interessantemente, mesmo as divergências parecem corroborar positivamente essa conclusão. Entre os indicadores estatisticamente relevantes são aqueles relacionados com comércio de serviços e influxo de investimento estrangeiro direto, o que fortalece a hipótese de interdependência.

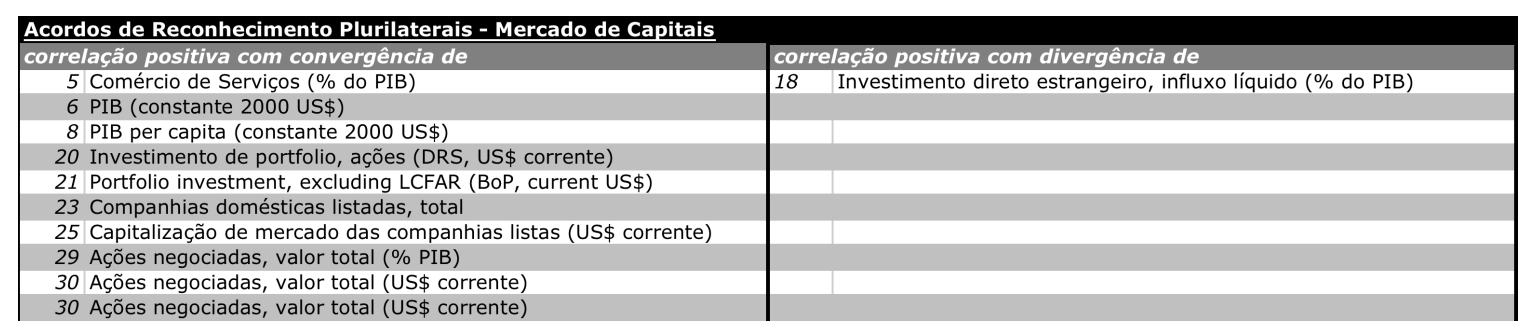

Em relação ao setor de mercado de capitais, a correlação parece ser mais relevante ainda, pois envolve relevantes indicadores macroeconômicos (comércio de serviços, PIB e PIB per capita) e diversos indicadores de mercado de capitais.

Faz-se mister recordar que processos de integração financeira via reconhecimento e harmonização, principalmente no que tange a União Européia, são imbricados, o que 
torna difícil separar os efeitos de cada tipo de processo. Inclusive, as séries relativas a processos de harmonização plurilateral tiveram de ser descartadas por colinearidade.

A assinatura de acordos plurilaterais de reconhecimento, portanto, parece apresentar grande correlação com a convergência de indicadores econômicos e setoriais.

\section{III.5.2.3. Acordos Multilaterais.}

A figura não parece ser tão clara em relação aos acordos multilaterais de reconhecimento. Os indicadores positivos estatisticamente relevantes são relacionados principalmente à relação capital/ativos, investimentos estrangeiros (saídas de investimentos diretos e investimento de portfólio), e empréstimos externos. Parece haver, portanto, correlação entre a assinatura do acordo multilateral incluindo a cláusula de reconhecimento (o GATS em 1994) e uma convergência dos indicadores de investimentos.

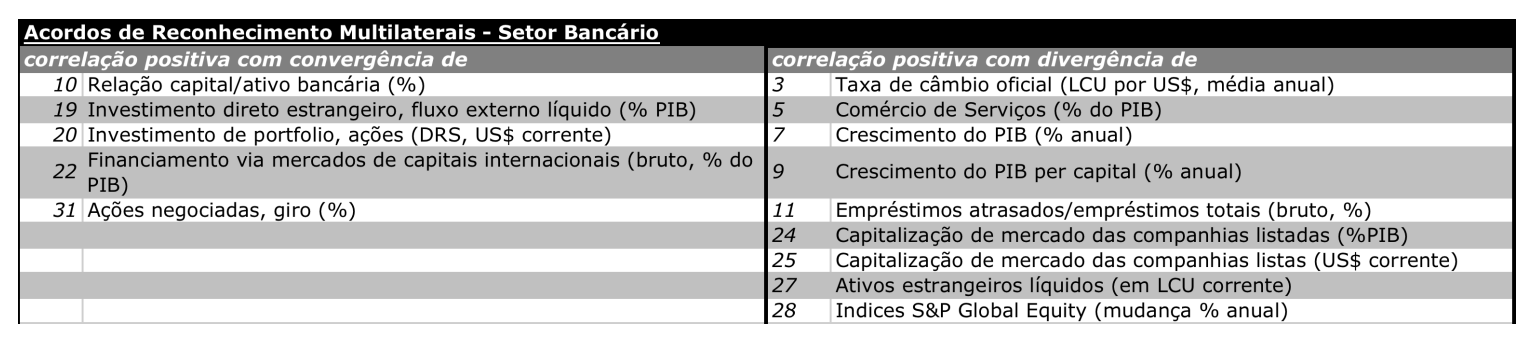

Todavia, o motivo da correlação parece não ser tão claro. Uma hipótese que poderia justificar sua ocorrência é a existência de conjuntura de liquidez internacional favorável, em que os diversos países estariam adotando políticas de captação de recursos externos que seriam aproximadamente homogêneas. O contexto doméstico dos países, todavia, parece ser bastante heterogêneo - é isso, ao menos, que os dados sobre divergência parecem indicar. 


\section{III.5.3. ACORDOS DE HARMONIZAÇÃO.}

\section{III.5.3.1. Acordos Bilaterais.}

A série referente à harmonização bilateral bancária teve de ser descartada em vista de colinearidade. Todavia, nota-se correlação estatisticamente significante entre acordos bilaterais em valores mobiliários e convergência de indicadores de mercados de capitais.

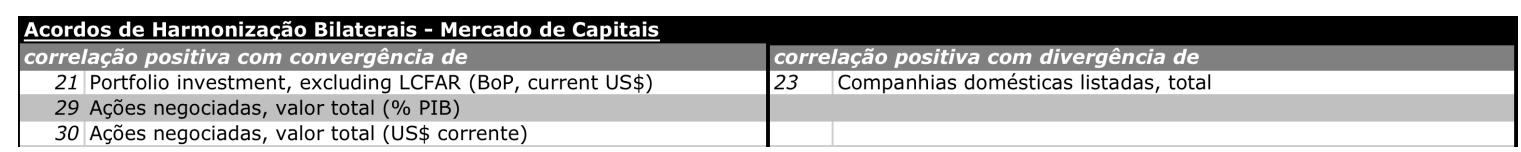

\section{III.5.3.2. Acordos Plurilaterais.}

Os processos de integração via harmonização plurilateral, como referido acima, são bastante difíceis de serem desentranhados dos processos de integração via reconhecimento. Isso implica que as séries foram descartadas devido a colinearidade.

\section{III.5.3.3. Acordos Multilaterais.}

Em relação à integração via harmonização multilateral, vale notar uma idiossincrasia importante. Trata-se de caso singular em que o processo estudado é a adoção do Acordo da Basiléia sobre requisitos de capital, que tem componentes de harmonização (entre os países do G10) e convergência (para todos os outros países).

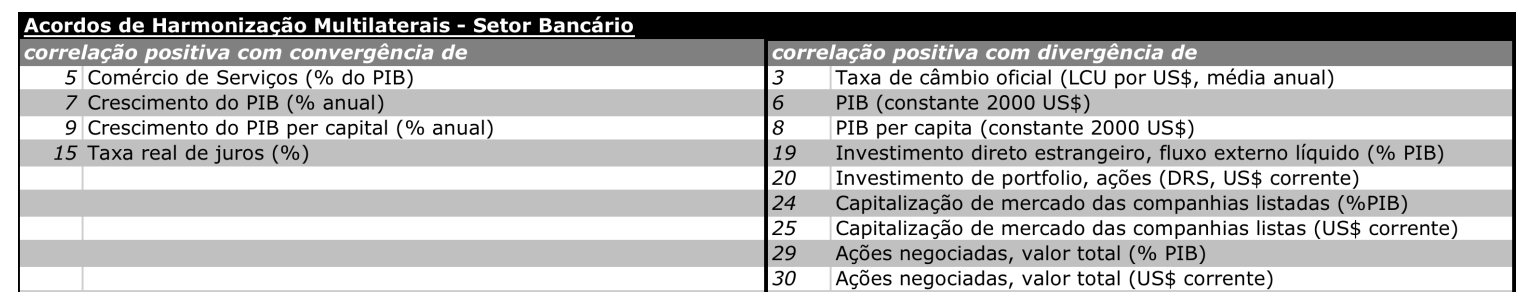

As correlações encontradas indicam que a adoção do acordo de Basiléia estaria correlacionado com convergência de taxas de crescimento do PIB e taxas reais de juros. 
Todavia, ao mesmo tempo tem-se correlação com divergência dos níveis do PIB, investimentos e mercados acionários. Tais resultados apontam grande heterogeneidade na situação econômica dos diversos países.

\section{III.5.4. ACORDOS DE COOPERAÇÃo.}

\section{III.5.3.1. Acordos Bilaterais e Multilaterais.}

Em relação à integração financeira via cooperação executiva entre autoridades regulatórias, registra-se que os únicos processos relevantes encontrados aconteceram no setor de valores mobiliários. Não havia séries disponíveis em relação ao setor bancário.

\begin{tabular}{|c|c|}
\hline correlação positiva com convergência de & correlação positiva com divergência de \\
\hline 6 PIB (constante 2000 US\$) & Comércio de Serviços (\% do PIB) \\
\hline 7 Crescimento do PIB (\% anual) & Investimento direto estrangeiro, influxo líquido (\% do PIB) \\
\hline 8 PIB per capita (constante 2000 US\$) & Portfolio investment, excluding LCFAR (BoP, current US\$) \\
\hline 9 Crescimento do PIB per capital ( $\%$ anual) & Ativos estrangeiros líquidos (em LCU corrente) \\
\hline \multirow{2}{*}{\multicolumn{2}{|c|}{$\begin{array}{l}15 \text { Taxa real de juros (\%) } \\
17 \text { Crédito doméstico, setor bancário (\% PIB) }\end{array}$}} \\
\hline & \\
\hline \multicolumn{2}{|l|}{19 Investimento direto estrangeiro, fluxo externo líquido (\% PIB) } \\
\hline \multicolumn{2}{|l|}{20 Investimento de portfolio, ações (DRS, US\$ corrente) } \\
\hline \multirow{2}{*}{\multicolumn{2}{|c|}{$\begin{array}{l}24 \text { Capitalização de mercado das companhias listadas (\%PIB) } \\
25 \text { Capitalização de mercado das companhias listas (US\$ corrente) }\end{array}$}} \\
\hline & \\
\hline \multicolumn{2}{|l|}{28 Indices S\&P Global Equity (mudança \% anual) } \\
\hline \multicolumn{2}{|l|}{29 Ações negociadas, valor total (\% PIB) } \\
\hline 30 Ações negociadas, valor total (US\$ corrente) & \\
\hline 31 Ações negociadas, giro (\%) & \\
\hline
\end{tabular}

Pode-se afirmar com segurança que a cooperação em matéria de valores mobiliários foi a que apresentou maior correlação com convergência dos indicadores setoriais de mercados de capitais. As séries de investimento estrangeiro, capitalização de mercado e ações negociadas, quando interagidas com ambos os tipos de acordos, bilaterais e multilaterais, correlacionam-se positivamente com a assinatura dos acordos de cooperação.

\begin{tabular}{|c|c|}
\hline correlação positiva com convergência de & correlação positiva com divergência de \\
\hline 18 Investimento direto estrangeiro, influxo líquido (\% do PIB) & \\
\hline 19 Investimento direto estrangeiro, fluxo externo líquido (\% PIB) & \\
\hline 20 Investimento de portfolio, ações (DRS, US\$ corrente) & \\
\hline 24 Capitalização de mercado das companhias listadas (\%PIB) & \\
\hline 25 Capitalização de mercado das companhias listas (US\$ corrente) & \\
\hline 28 Indices S\&P Global Equity (mudança \% anual) & \\
\hline 29 Ações negociadas, valor total (\% PIB) & \\
\hline 31 Ações negociadas, giro (\%) & \\
\hline
\end{tabular}




\section{III.6. CONCLUSÕES.}

O presente capítulo apresentou os resultados de um exercício econométrico que buscou correlações entre a convergência e divergência de variáveis econômicas de pares de países, e dummy de processos de integração financeira. Os processos estudados foram acordos de comércio, acordos de reconhecimento, acordos de harmonização, e acordos de cooperação, nas modalidades bilateral, plurilateral e multilateral. Analisou-se 91 x 91 pares de países por 36 anos (1973 a 2008). Buscou-se correlações entre 31 pares de variáveis econômicas de três diferentes tipos: macroeconômicas, setoriais bancárias e setoriais de mercados de capitais.

Entre os acordos de comércio, notou-se bastante heterogeneidade nos resultados, principalmente no que se refere às modalidades. Acordos bilaterais e plurilaterais parecem estar relacionados a uma convergência um pouco maior de variáveis macroeconômicas (PIB) e divergência de indicadores de investimento. Em acordos multilaterais as divergências são ainda mais fortes, o que parece implicar bastante heterogenia.

Os acordos de reconhecimento bilaterais, principalmente em mercado de capitais, aparecem correlacionados convergência de PIB e indicadores de mercado acionário. Nos acordos plurilaterais, foi encontrada correlação também com convergência de indicadores bancários (setor bancário) e mercado de capitais. Em relação aos acordos multilaterais, os indicadores parecem ser mais dúbios e menos coerentes, o que dificultou a interpretação.

Em relação aos acordos de harmonização, os resultados foram prejudicados pelo descarte de algumas séries tendo em vista colinearidade, principalmente com séries relativas a acordos reconhecimento. Os resultados mais relevantes vieram dos processos de integração multilateral. Todavia, encontrou-se muita heterogeneidade: correlação positiva com convergência de taxas de crescimento de PIB, mas negativa (divergência) com níveis de PIB, investimentos e indicadores de mercados acionários.

Finalmente, em relação aos acordos de cooperação, encontrou-se correlação com convergência em diversos dos indicadores analisados, macroeconômicos e setoriais. 
Anexo I - Lista de ACORdos de COOPERAÇÃo

\begin{tabular}{|c|c|c|c|}
\hline & Acor: & po & vigor \\
\hline 1 & $\begin{array}{l}\text { Memorandum of Understanding concerning the exchange of information between the Governmen } \\
\text { America and the Government of Switzerland. }\end{array}$ & Bilateral & 31-Aug-82 \\
\hline 2 & $\begin{array}{l}\text { Memorandum of Understanding concerning the exchange of information between the Commodity Futures Trading } \\
\text { Commission and the United States Securities and Exchange Commission, and the Department of Trade and Industry and } \\
\text { the Financial Services Authority of the United Kingdom. (September } 23,1986 \text { / November 22, 1988) }\end{array}$ & Bilateral & 23-Sep-86 \\
\hline 3 & $\begin{array}{l}\text { Memorandum of Understanding between the Financial Services Agency of Japan and the Department of Trade and Industry } \\
\text { of the United Kingdom. }\end{array}$ & Bilateral & 08-Apr-87 \\
\hline 4 & $\begin{array}{l}\text { Memorandum of Understanding concerning Mutual Co-operation, the Exchange of Information and Investigative Assistance } \\
\text { between the United States Securities and Exchange Commission, the Ontario Securities Commission, the Commission des } \\
\text { valeurs mobiliéres du Québec and the British Columbia Securities Commission. }\end{array}$ & Bilateral & 07-Jan-88 \\
\hline 5 & $\begin{array}{l}\text { Memorandum of Understanding regarding the Exchange of Information and Co-operation in general between the } \\
\text { Kredittilsynet of Norway, the Finanstilsynet of Denmark, the Finansinspektionen of Finland, the Sedlabanki Islands of } \\
\text { Iceland and the Finansinspektionen of Sweden. }\end{array}$ & Bilateral & 31-May-88 \\
\hline 6 & $\begin{array}{l}\text { Memorandum of Understanding concerning the exchange of information and general cooperation between the } \\
\text { Finanstilsynet of Denmark, the Financial Supervision Authority of Finland, the Sedlabanki Islands (Iceland), the Bank } \\
\text { Inspection Board of Sweden and the Kredit Tilsynet of Norway. }\end{array}$ & Bilateral & 31-May-88 \\
\hline 7 & $\begin{array}{l}\text { Memorandum of Understanding concerning the Exchange of Information between the Comissão de Valores Mobiliários of } \\
\text { Brazil and the Securities and Exchange Commission of the United States. }\end{array}$ & Bilateral & 01-Jul-88 \\
\hline 8 & $\begin{array}{l}\text { Memorandum of Understanding between the Financial Services Authority and the Department of Trade and Industry of the } \\
\text { United Kingdom, and the Financial Services Agency of Japan. }\end{array}$ & Bilateral & 03-Oct-88 \\
\hline 9 & $\begin{array}{l}\text { Memorandum of Understanding concerning cooperation in supervision, including the exchange of information between the } \\
\text { Financial Services Authority of the United Kingdom and the Kredit Tilsynet of Norway. }\end{array}$ & Bilateral & 01-Dec-88 \\
\hline 10 & $\begin{array}{l}\text { Memorandum of Understanding concerning financial supervision of the U.K branches of Swedish banks between the } \\
\text { Financial Services Authority, the Securities Association of the United Kingdom and the Bank Inspection Board of Sweden }\end{array}$ & Bilateral & 01-Dec-88 \\
\hline 11 & $\begin{array}{l}\text { Administrative Agreement concerning the Exchange of Information between the Securities Board of the Netherlands and } \\
\text { the United States Securities and Exchange Commission. }\end{array}$ & Bilateral & 11-Dec-89 \\
\hline 12 & $\begin{array}{l}\text { Administrative Agreement concerning mutual assistance between the United States Securities and Exchange Commission } \\
\text { and the Commission des Opérations de Bourse of France. }\end{array}$ & Bilateral & 14-Dec-89 \\
\hline 13 & $\begin{array}{l}\text { Memorandum of Understanding concerning the exchange of information between the United States Securities and } \\
\text { Exchange Commission and the Institut Monétaire Luxembourgeois. }\end{array}$ & Bilateral & 23-May-90 \\
\hline 14 & $\begin{array}{l}\text { Agreement concerning technical assistance for the development of the Hungarian securities market between the United } \\
\text { States Securities and Exchange Commission, and the Hungarian Financial Supervisory Agency and the Budapest Stock } \\
\text { Exchange. }\end{array}$ & Bilateral & 22-Jun-90 \\
\hline 15 & $\begin{array}{l}\text { Memorandum of Understanding concerning consultation, technical assistance and mutual assistance for the exchange of } \\
\text { information between the United States Securities and Exchange Commission and the Comisión Nacional Bancaria y de } \\
\text { Valores of Mexico. }\end{array}$ & Bilateral & $18-$ Oct-90 \\
\hline 16 & $\begin{array}{l}\text { Memorandum of Understanding between the Superintendencia General de Valores of Costa Rica and the Comisión Nacional } \\
\text { Bancaria y de Valores of Mexico. }\end{array}$ & Bilateral & 01-Nov-90 \\
\hline 17 & $\begin{array}{l}\text { Memorandum of Understanding concerning Consultation and Technical Assistance between the Comissão de Valores } \\
\text { Mobiliários of Brazil and the Comisión Nacional Bancaria y de Valores of Mexico. }\end{array}$ & Bilateral & 16-Nov-90 \\
\hline 18 & $\begin{array}{l}\text { Memorandum of Understanding on Consultation and Technical Assistance between the Comisión Nacional de Valores of } \\
\text { Argentina and the Comisión Nacional Bancaria y de Valores of Mexico. }\end{array}$ & Bilateral & 19-Nov-90 \\
\hline 19 & $\begin{array}{l}\text { Memorandum of Understanding concerning Co-operation and Exchange of Information between the Superintendencia de } \\
\text { Valores y Seguros of Chile and the Comisión Nacional Bancaria y de Valores of Mexico. }\end{array}$ & Bilateral & 31-Mar-91 \\
\hline 20 & $\begin{array}{l}\text { Memorandum of Understanding concerning consultation and cooperation in the administration and setting up of laws } \\
\text { regarding securities between the United States Securities and Exchange Commission and the Kredit Tilsynet of Norway. }\end{array}$ & Bilateral & 24-Sep-91 \\
\hline 21 & $\begin{array}{l}\text { Memorandum of Understanding concerning the Exchange of Information and Technical Co-operation between the } \\
\text { Commission des valeurs mobilières du Québec and the Hungarian Financial Supervisory Authority. }\end{array}$ & Bilateral & $02-0 c t-91$ \\
\hline 22 & $\begin{array}{l}\text { Memorandum of Understanding concerning Co-operation, Mutual Understanding and the Exchange of Information between } \\
\text { the Federal Department of Finance of the Swiss Confederation and the United Kingdom Department of Trade and Industry. }\end{array}$ & Bilateral & 30-Oct-91 \\
\hline 23 & $\begin{array}{l}\text { Memorandum of Understanding concerning consultation, technical assistance and mutual assistance for the exchange of } \\
\text { information between the Comisión Nacional de Valores of Argentina and the United States Securities and Exchange } \\
\text { Commission. }\end{array}$ & Bilateral & 09-Dec-91 \\
\hline 24 & $\begin{array}{l}\text { Memorandum of Understanding on Consultation and Technical Assistance between the Comisión Nacional de Valores of } \\
\text { Argentina and the Comisión de Valores Mobiliários of Brazil. }\end{array}$ & Bilateral & 7-Dec-91 \\
\hline 25 & $\begin{array}{l}\text { Memorandum of Understanding concerning Consultation and Technical Assistance between the Comisión Nacional } \\
\text { Supervisora de Empresas y Valores of Peru and the Superintendencia de Valores y Seguros of Chile. }\end{array}$ & Bilateral & 30-Jan-92 \\
\hline 26 & $\begin{array}{l}\text { Administrative Agreement on Mutual Assistance between the Commission des Opérations de Bourse of France and the } \\
\text { Commission des valeurs mobilières du Québec. }\end{array}$ & Bilateral & 31-Jan-92 \\
\hline 27 & $\begin{array}{l}\text { Administrative Agreement regarding the Exchange of Information between the Hungarian Financial Supervisory Authority } \\
\text { and the Ouébec Securities Commission. }\end{array}$ & Bilateral & 04-Mar-92 \\
\hline 28 & $\begin{array}{l}\text { Memorandum of Understanding on Consultation and Technical Assistance between the Comisión Nacional de Valores of } \\
\text { Argentina and the Comisión Nacional Supervisora de Empresas y Valores of Peru. }\end{array}$ & Bilateral & 24-Mar-92 \\
\hline 29 & $\begin{array}{l}\text { Memorandum of Understanding regarding the Provision of Technical Assistance for the Development and Mutual Co- } \\
\text { operation between the United States Securities and Exchange Commission and the Capital Market Supervisory Agency of } \\
\text { Indonesia. }\end{array}$ & Bilateral & 24-Mar-92 \\
\hline 30 & $\begin{array}{l}\text { Memorandum of Understanding on Consultation and Technical Assistance between the Comisión Nacional de Valores of } \\
\text { Argentina and the Superintendencia de Valores y Seguros of Chile. }\end{array}$ & Bilateral & 28-Apr-92 \\
\hline 31 & $\begin{array}{l}\text { Memorandum of Understanding to facilitate long-term Cooperation and to Exchange Information between the Malta Stock } \\
\text { Exchange and the London Stock Exchange of the United Kingdom. }\end{array}$ & Bilateral & 1-Jun-92 \\
\hline 32 & $\begin{array}{l}\text { Memorandum of Understanding on Technical Assistance between the Comisión Nacional de Valores of Argentina and the } \\
\text { Comisión Nacional del Mercado de Valores of Spain. }\end{array}$ & Bilateral & 5-Jun-92 \\
\hline 33 & $\begin{array}{l}\text { Memorandum of Understanding concerning consultation and cooperation in the administration of laws related to the } \\
\text { securities market between the Comisión Nacional del Mercado de Valores of Spain and the United StatesSecurities and } \\
\text { Exchange Commission. }\end{array}$ & Bilateral & 08-Jul-92 \\
\hline 34 & $\begin{array}{l}\text { Memorandum of Understanding on Consultation and Technical Assistance between the Comisión Nacional de Valores of } \\
\text { Argentina and the Comisión Nacional de Valores of Bolivia. }\end{array}$ & Bilateral & 28-Jul-92 \\
\hline 35 & $\begin{array}{l}\text { Memorandum of Understanding on Consultation and Technical Assistance between the Comisión Nacional de Valores of } \\
\text { Argentina and the Comisión Nacional de Valores of Paraguay. }\end{array}$ & Bilateral & 07-Aug-92 \\
\hline 36 & $\begin{array}{l}\text { Memorandum of Understanding concerning Consultation and Technical Assistance between the Comisión Nacional de } \\
\text { Valores of Costa Rica and the Superintendencia de Valores y Seguros of Chile. }\end{array}$ & Bilateral & 24-Sep-92 \\
\hline 37 & $\begin{array}{l}\text { Administrative Agreement concerning Co-operation and the Exchange of Information between the Commission des } \\
\text { Opérations de Bourse of France and the British Columbia Securities Commission. }\end{array}$ & Bilateral & $06-0 c t-92$ \\
\hline 38 & $\begin{array}{l}\text { Administrative Agreement concerning Mutual Co-operation and Technical Assistance between the } C \\
\text { Opérations de Bourse of France and the Comisión Nacional de Valores of Mexico. }\end{array}$ & Bilateral & 23-Oct-92 \\
\hline 39 & $\begin{array}{l}\text { Sscurities and Investment Board of the United Kingdom (Present FSA) and t } \\
\text { ssion. }\end{array}$ & Bilateral & $28-0 c t-92$ \\
\hline 40 & $\begin{array}{l}\text { Memorandum of Understanding concerning cooperation, mutual assistance and the exchange of information between the } \\
\text { Securities and Futures Commission of Hong Kong, Her Majesty's Treasury and the Financial Services Authority of the } \\
\text { United Kingdom. }\end{array}$ & Bilateral & $28-0 c t-92$ \\
\hline 41 & $\begin{array}{l}\text { Cooperative Arrangement for information sharing on matters related to program specific arrangements between the } \\
\text { Ministry of Agriculture, Forestry and Fisheries of Japan and the Commodity Futures Trading Commission of the United } \\
\text { States of America. }\end{array}$ & Bilateral & 01-Dec-92 \\
\hline 42 & $\begin{array}{l}\text { Memorandum of Understanding concerning Consultation and Technical Assistance between the Superintendencia de Valores } \\
\text { of Colombia and the Superintendencia de Valores y Seguros of Chile. }\end{array}$ & Bilateral & 02-Feb-93 \\
\hline 43 & $\begin{array}{l}\text { Memorandum of Understanding concerning the Exchange of Information between The Monetary Authority of Singapore and } \\
\text { the Securities and Futures Commission of Chinese Taipei. }\end{array}$ & Bilateral & 08-Feb-93 \\
\hline 44 & $\begin{array}{l}\text { Memorandum of Understanding concerning Consultation and Technical Assistance between the Superintendencia de Valor } \\
\text { of Colombia and the Comisión Nacional Bancaria y de Valores of Mexico. }\end{array}$ & Bilateral & 5-Mar-93 \\
\hline 45 & $\begin{array}{l}\text { Memorandum of Understanding on Consultation and Technical Assistance between the Comisión Nacional de Valores of } \\
\text { Argentina and the Comisión Nacional de Valores of Costa Rica. }\end{array}$ & Bilateral & 25-Mar-93 \\
\hline 46 & $\begin{array}{l}\text { Memorandum of Understanding concerning the exchange of information between the United States Securities and } \\
\text { Exchange Commission and the Commissione Nazionale per le Società e la Borsa of Italy. }\end{array}$ & Bilateral & 03-May-93 \\
\hline 47 & $\begin{array}{l}\text { Memorandum of Understanding on Co-operation and Technical Assistance between the Comisión Nacional de Valores of } \\
\text { Argentina and the Commission des Opérations de Bourse of France. }\end{array}$ & Bilateral & 24-May-93 \\
\hline 48 & US-Chile (Enforcement Cooperation) & Bilateral & 03-Jun-93 \\
\hline 49 & $\begin{array}{l}\text { Memorandum of Understanding on Consultation and Technical Assistance between the Comisión Nacional de Valores of } \\
\text { Argentina, the Superintendencia de Valores of Colombia and the Comisión Nacional de Valores of Paraguay. }\end{array}$ & Bilateral & 04-Jun-93 \\
\hline 50 & $\begin{array}{l}\text { Memorandum of Understanding concerning Consultation and Technical Assistance, between the Superintendencia de } \\
\text { Valores of Colombia, the Comisión Nacional de Valores of Argentina and the Comisión Nacional de Valores of Paragua }\end{array}$ & Bilateral & 04-Jun-93 \\
\hline
\end{tabular}




\begin{tabular}{|c|c|c|c|}
\hline & Acordos de Coo & Tipo & Entrada em vigor \\
\hline 51 & $\begin{array}{l}\text { Memorandum of Understanding between the Securities and Investments Board, the Securities Board of the Netherlands, } \\
\text { the Investment Management Regulatory Organisation and the Securities and Futures Authority on the Supervision of } \\
\text { Undertakings Authorized in the United Kingdom carrying on Investment Business in the Netherlands. }\end{array}$ & Bilateral & 14-Jun-93 \\
\hline 52 & $\begin{array}{l}\text { Memorandum of Regulatory Cooperation between the Securities and Futures Commission of Hong Kong and the Securities } \\
\text { and the China Securities Regulatory Commission, Shangai Securities Exchange, Shenzen Stock Exchange and the Stock } \\
\text { Exchange of Hong Kong Limited. }\end{array}$ & Bilateral & 19-Jun-93 \\
\hline 53 & $\begin{array}{l}\text { Memorandum of Understanding on Technical Assistance between the Comisión Nacional de Valores of Argentina and the } \\
\text { Commissione Nazionale per le Societá e la Borsa of Italy. }\end{array}$ & Bilateral & 22-Jun-93 \\
\hline 54 & $\begin{array}{l}\text { Administrative Agreement concerning the Exchange of Information between the Commissione Nazionale per le Societá e la } \\
\text { Borsa of Italy and the Commission des Opérations de Bourse of France. }\end{array}$ & Bilateral & 22-Jun-93 \\
\hline 55 & $\begin{array}{l}\text { Memorandum of Understanding concerning Consultation and Technical Assistance between the Comisión Nacional de } \\
\text { Valores of Paraguay and the Superintendencia de Valores y Seguros of Chile. }\end{array}$ & Bilateral & $13-J u l-93$ \\
\hline 56 & $\begin{array}{l}\text { Administrative Agreement concerning the Exchange of Information between the Commission des Opérations de Bourse of } \\
\text { France and the Commission Bancaire et Financière of Belgium. }\end{array}$ & Bilateral & $26-J u l-93$ \\
\hline 57 & $\begin{array}{l}\text { Memorandum of Understanding on the Exchange of Information between the Commission des valeurs mobilières du } \\
\text { Québec and the Ministry of Finance of Rumania, represented by the Romanian National Securities Commission. }\end{array}$ & Bilateral & 23-Sep-93 \\
\hline 58 & $\begin{array}{l}\text { Memorandum of Understanding on the Exchange of Information between the Comisión Nacional del Mercado de Valores of } \\
\text { Spain and the Commission des Opérations de Bourse of France. }\end{array}$ & Bilateral & $27-$ Sep-93 \\
\hline 59 & $\begin{array}{l}\text { Memorandum of Understanding concerning Mutual Assistance between the Securities and Futures Commission of Hong } \\
\text { Kong and the Australian Securities and Investments Commission. }\end{array}$ & Bilateral & 29-Sep-93 \\
\hline 60 & $\begin{array}{l}\text { Memorandum of Understanding concerning Consultation and Co-operation in the Administration and Enforcement of } \\
\text { Securities Laws between the Office of the Securities and Exchange Commission of Thailand and the Australian Securities } \\
\text { and Investments Commission. }\end{array}$ & Bilateral & 20-Oct-93 \\
\hline 61 & $\begin{array}{l}\text { Memorandum of Understanding concerning consultation and cooperation in the administration and enforcement of } \\
\text { securities laws between the Australian Securities and Investments Commission and the United States Securities and } \\
\text { Exchange Commission. }\end{array}$ & Bilateral & $20-$ Oct-93 \\
\hline 62 & $\begin{array}{l}\text { Memorandum of Understanding for Consultation and Co-operation in Enforcement of Legal Procedures between the } \\
\text { Comisión Nacional del Mercado de Valores of Spain and the Superintendencia de Valores y Seguros of Chile. }\end{array}$ & Bilateral & $25-$ Oct-93 \\
\hline 63 & $\begin{array}{l}\text { Memorandum of Understanding concerning Technical Assistance between the Superintendencia de Valores of Colombia and } \\
\text { the Comisión Nacional del Mercado de Valores of Spain. }\end{array}$ & Bilateral & 25-Oct-93 \\
\hline 64 & $\begin{array}{l}\text { Memorandum of Understanding regarding Consultation and Technical Assistance between the Comisión Nacional de Valores } \\
\text { of Mexico and the Comisión Nacional de Valores of Paraguay. }\end{array}$ & Bilateral & $25-0 c t-93$ \\
\hline 65 & $\begin{array}{l}\text { Memorandum of Understanding regarding Consultation and Technical Assistance between the Comisión Nacional de Valores } \\
\text { of Mexico and the Comisión Nacional de Valores of Panama. }\end{array}$ & Bilateral & 27-Oct-93 \\
\hline 66 & $\begin{array}{l}\text { Memorandum of Understanding concerning Technical Assistance between the Comisión Nacional de Valores of Argentina } \\
\text { and the Comisión Nacional de Valores of Panama. }\end{array}$ & Bilateral & $28-0 c t-93$ \\
\hline 67 & $\begin{array}{l}\text { Memorandum of Understanding on Consultation and Technical Assistance between the Superintendencia de Valores of } \\
\text { Colombia and the Superintendencia General de Valores of Costa Rica. }\end{array}$ & Bilateral & 28-Oct-93 \\
\hline 68 & $\begin{array}{l}\text { Memorandum of Understanding concerning Mutual Assistance and the Exchange of Information between the Securities and } \\
\text { Futures Commission of Hong Kong and the Securities and Exchange Commission of Thailand. }\end{array}$ & Bilateral & 12 -Nov-93 \\
\hline 69 & US-Germany (Enforcement Cooperation) & Bilateral & 22-Nov-93 \\
\hline 70 & $\begin{array}{l}\text { Memorandum of Understanding between the Securities Commission of Malaysia and the Capital Market Supervisory Agency } \\
\text { of Indonesia. }\end{array}$ & Bilateral & $12-J a n-94$ \\
\hline 71 & $\begin{array}{l}\text { Memorandum of Understanding on the Exchange of Information between the Commission des Opérations de Bourse of } \\
\text { France and the Commissione Nazionale per le Societá e la Borsa of Italy. }\end{array}$ & Bilateral & 27-Jan-94 \\
\hline 72 & $\begin{array}{l}\text { Administrative Agreement concerning the Exchange of Information between the Commissione Nazionale per le Societá e la } \\
\text { Borsa of Italy and the Commission Bancaire et Financière of Belgium. }\end{array}$ & Bilateral & $15-F e b-94$ \\
\hline 73 & $\begin{array}{l}\text { Memorandum of Understanding concerning Consultation and Technical Assistance between the Superintendencia de Valores } \\
\text { of Colombia and the Comisión Nacional de Valores of Venezuela. }\end{array}$ & Bilateral & $16-F e b-94$ \\
\hline 74 & $\begin{array}{l}\text { Memorandum of Understanding concerning Mutual Assistance and the Exchange of Information between the Securities and } \\
\text { Futures Commission of Hong Kong and the Malaysia Securities Commission. }\end{array}$ & Bilateral & 22-Feb-94 \\
\hline 75 & $\begin{array}{l}\text { Memorandum of Understanding for Mutual Assistance to facilitate the Exchange of Information and to enforce a secure } \\
\text { compliance with any law or regulation between the Securities Commission of Malaysia and the Securities and Exchange } \\
\text { Commission of Thailand. }\end{array}$ & Bilateral & 04-Apr-94 \\
\hline 76 & $\begin{array}{l}\text { Memorandum of Understanding concerning the Exchange of Information between the Comisión Nacional del Mercado de } \\
\text { Valores of Spain and the Commission Bancaire et Financière of Belgium. }\end{array}$ & Bilateral & 14-Apr-94 \\
\hline 77 & $\begin{array}{l}\text { Memorandum of Understanding on Consultation and Technical Assistance between the Superintendencia de Valores of } \\
\text { Colombia and the Superintendencia de Compañías of Ecuador. }\end{array}$ & Bilateral & 25-Apr-94 \\
\hline 78 & $\begin{array}{l}\text { Memorandum of Understanding regarding Mutual Co-operation and Technical Assistance between the Comisión Nacional de } \\
\text { Valores of Mexico and the Superintendencia de Compañías of Ecuador. }\end{array}$ & Bilateral & 6-Apr-94 \\
\hline 79 & $\begin{array}{l}\text { Memorandum of Understanding concerning cooperation, consultation and the provision of technical assistance between the } \\
\text { China Securities Regulatory Commission and the United States Securities and Exchange Commission. }\end{array}$ & Bilateral & 28-Apr-94 \\
\hline 80 & $\begin{array}{l}\text { Memorandum of Understanding on the Exchange of Information and Technical Assistance between the Superintendencia } \\
\text { General de Valores of Costa Rica and the Comisión Nacional de Valores of Paraguay. }\end{array}$ & Bilateral & 13-May-94 \\
\hline 81 & $\begin{array}{l}\text { Administrative Agreement for the Exchange of Information between the Comissão do Mercado de Valores Mobiliários of } \\
\text { Portugal and the Comisión Nacional del Mercado de Valores of Spain. }\end{array}$ & Bilateral & 16-May-94 \\
\hline 82 & $\begin{array}{l}\text { Memorandum of Understanding on Mutual Co-operation and the Exchange of Information between the Commission des } \\
\text { Opérations de Bourse of France and the Securities and Futures Commission of Hong Kong. }\end{array}$ & Bilateral & 14-Jun-94 \\
\hline 83 & $\begin{array}{l}\text { Memorandum of Understanding regarding Mutual Consultation and Technical Assistance for the Exchange of Information } \\
\text { between the Comisión Nacional de Valores of Mexico and the Comisión Nacional del Mercado de Valores of Spain. }\end{array}$ & Bilateral & 14-Jun-94 \\
\hline 84 & $\begin{array}{l}\text { Administrative Agreement for the Exchange of Information between the Comisión Nacional del Mercado de Valores of Spain } \\
\text { and the Commissione Nazionale per le Societá e la Borsa of Italy. }\end{array}$ & Bilateral & 5-Jun-94 \\
\hline 85 & $\begin{array}{l}\text { Memorandum of Understanding concerning Mutual Assistance and Administrative Arrangement between the Commission } \\
\text { des Opérations de Bourse of France and the Securities and Futures Commission of Chinese Taipei. }\end{array}$ & Bilateral & 20-Jun-94 \\
\hline 86 & $\begin{array}{l}\text { Memorandum of Understanding concerning division of responsibilities, notification, exchange of information, cooperation in } \\
\text { supervision and on-site controls between the Institut Monétaire Luxembourgeois and the Kredit Tilsynet of Norway. }\end{array}$ & Bilateral & 01-Jul-94 \\
\hline 87 & $\begin{array}{l}\text { Agreement concerning Mutual Co-operation and Technical Assistance between the Comisión Nacional de Valores of Mexico } \\
\text { and the Comisión Nacional Supervisora de Empresas y Valores of Peru. }\end{array}$ & Bilateral & $15-J u l-94$ \\
\hline 88 & $\begin{array}{l}\text { Memorandum of Understanding for Co-operation concerning banking supervision after the implementation of the Second } \\
\text { Banking Coordination Directive between the Finansinspektionen of Sweden and the Institut Monetaire of Luxembourg. }\end{array}$ & Bilateral & 19-Jul-94 \\
\hline 89 & $\begin{array}{l}\text { Memorandum of Understanding on Co-operation concerning banking supervision after the implementation of the Second } \\
\text { Banking Coordination Directive between the Finansinspektionen of Sweden, the Commission Bancaire and Committé des } \\
\text { Etablissements de Crédit of France. }\end{array}$ & Bilateral & 21-Jul-94 \\
\hline 90 & $\begin{array}{l}\text { Memorandum of Understanding relating to the Exchange of Information between the Securities Commission of New } \\
\text { Zealand and the Australian Securities and Investments Commission. }\end{array}$ & Bilateral & 01-Aug-94 \\
\hline 91 & $\begin{array}{l}\text { Memorandum of Understanding concerning the Exchange of Information between the Comissão do Mercado de Valores } \\
\text { Mobiliários of Portugal and the Commission Bancaire et Financière of Belgium. }\end{array}$ & Bilateral & $12-\operatorname{Sep}-94$ \\
\hline 92 & $\begin{array}{l}\text { Agreement concerning Mutual Co-operation and Technical Assistance between the Comisión Nacional de Valores of Mexico } \\
\text { and the Comissão do Mercado de Valores Mobiliários of Portugal. }\end{array}$ & Bilateral & 94 \\
\hline 93 & $\begin{array}{l}\text { Memorandum of Understanding regarding Mutual Assistance for the Exchange of Information between the Commissione } \\
\text { Nazionale per le Societá e la Borsa of Italy and the Ontario Securities Commission. }\end{array}$ & Bilateral & 19-Oct-94 \\
\hline 94 & $\begin{array}{l}\text { Memorandum of Understanding regarding Technical Assistance and the Exchange of Information between the Comisión } \\
\text { Nacional de Valores of Peru and the Comisión Nacional del Mercado de Valores of Spain. }\end{array}$ & Bilateral & 20-Oct-94 \\
\hline 95 & $\begin{array}{l}\text { Memorandum of Understanding concerning Mutual Assistance and the Exchange of Information between the Securities and } \\
\text { Futures Commission of Hong Kong and the Capital Market Supervisory Agency of Indonesia. }\end{array}$ & Bilateral & 31-Oct-94 \\
\hline 96 & $\begin{array}{l}\text { Memorandum of Understanding concerning division of responsibilities, notification, the exchange of information, } \\
\text { cooperation in supervision and on-site controls between the Commission bancaire, the Comite des établissements de crédit } \\
\text { of France and the Kredit Tilsynet of Norway. }\end{array}$ & Bilateral & 01-Nov-94 \\
\hline 97 & $\begin{array}{l}\text { Memorandum of Understanding concerning the Exchange of Information and Technical Assistance between the Comissão } \\
\text { de Valores Mobiliários of Brazil and the Comisión Nacional de Valores of Paraguay. }\end{array}$ & Bilateral & 24-Nov-94 \\
\hline 98 & $\begin{array}{l}\text { Memorandum of Understanding on the Exchange of Information and Technical Assistance between the Superintendencia } \\
\text { General de Valores of Costa Rica and the Comisión Nacional de Valores of Panama. }\end{array}$ & Bilateral & 29-Nov-94 \\
\hline 99 & $\begin{array}{l}\text { Memorandum of Understanding concerning division of responsibilities, notification, exchange of information, cooperation in } \\
\text { supervision and on site controls between De Nederlandsche Bank NV of Holland and the Kredit Tilsynet of Norway. }\end{array}$ & Bilateral & 01-Dec-94 \\
\hline 100 & $\begin{array}{l}\text { Memorandum of Understanding regarding Technical Assistance and the Exchange of Information between the Comis } \\
\text { Nacional de Valores of Paraguay and the Comisión Nacional Supervisora de Empresas y Valores of Peru. }\end{array}$ & Bilateral & 14-Dec-94 \\
\hline
\end{tabular}




\begin{tabular}{|c|c|c|c|}
\hline & Acordos de $\mathrm{Co}$ & & Entrada em vigor \\
\hline 101 & $\begin{array}{l}\text { Memorandum of Understanding on the Exchange of Information and Technical Assistance between the Superinte } \\
\text { General de Valores of Costa Rica and the Superintendencia de Compañías of Ecuador. }\end{array}$ & Bilateral & 19-Jan-95 \\
\hline 102 & US-Israel (Enforcement Cooperation) & Bilateral & 13-Feb-95 \\
\hline 103 & $\begin{array}{l}\text { Administrative Agreement for the Exchange of Information between the Commission des Opérations de Bourse of France } \\
\text { and the Australian Securities and Investments Commission. }\end{array}$ & Bilateral & 14-Mar-95 \\
\hline 04 & $\begin{array}{l}\text { Memorandum of Understanding concerning the Exchange of Information between the Interchange Association of Japan and } \\
\text { the Securities and Futures Commission of Chinese Taipei. }\end{array}$ & Bilateral & 24-Apr-95 \\
\hline 105 & $\begin{array}{l}\text { Memorandum of Understanding concerning the Exchange of Information between the Interchange Association of Japan and } \\
\text { the Securities and Futures Commission of Chinese Taipei. }\end{array}$ & Bilateral & 24-Apr-95 \\
\hline 106 & $\begin{array}{l}\text { Memorandum of Understanding concerning Mutual Assistance, Co-operation and Sharing of Information between the } \\
\text { Financial Services Board of South Africa and the International Association of Insurance Supervisors. }\end{array}$ & Bilateral & 06-Jun-95 \\
\hline 107 & $\begin{array}{l}\text { Memorandum of Understanding concerning Consultation and Technical Assistance between the Superintendencia de Valores } \\
\text { of Colombia and the Superintendencia de Pensiones, Valores y Seguros of Bolivia. }\end{array}$ & Bilateral & 08-Jun-95 \\
\hline 108 & $\begin{array}{l}\text { Memorandum of Understanding for Mutual Cooperation regarding the Exchange of Information and Investigative Assistance } \\
\text { in matters relating to the Administration and Enforcement of Securities laws between the Ontario Securities Commission } \\
\text { and the Australian Securities and Investments Commission. }\end{array}$ & Bilateral & 05-Jul-95 \\
\hline 109 & $\begin{array}{l}\text { Memorandum of Understanding concerning the Exchange of Information and Technical Assistance between the Comissão } \\
\text { de Valores Mobiliários of Brazil and the Comissão do Mercado de Valores Mobiliários of Portugal. }\end{array}$ & Bilateral & 07-Jul-95 \\
\hline 110 & $\begin{array}{l}\text { Memorandum of Understanding on Technical Assistance between the Comisión Nacional de Valores of Argentina and the } \\
\text { Superintendencia de Compañías of Ecuador. }\end{array}$ & Bilateral & 10-Jul-95 \\
\hline 111 & $\begin{array}{l}\text { Memorandum of Understanding regarding Technical Cooperation between the Comisión Nacional del Mercado de Valores of } \\
\text { Spain and the Comisión Nacional de Valores of Panama. }\end{array}$ & Bilateral & 24-Jul-95 \\
\hline 112 & $\begin{array}{l}\text { Memorandum of Understanding concerning Consultation and Technical Assistance between the Superintendencia de } \\
\text { Compañías of Ecuador and the Superintendencia de Valores y Seguros of Chile. }\end{array}$ & Bilateral & 28-Jul-95 \\
\hline 113 & $\begin{array}{l}\text { Memorandum of Understanding on their Co-operation in the field of Banking Supervision after the implementation of the } \\
\text { second Banking Coordination Directive between the Finansinspektionen of Sweden and the Bundesaufsichtsamt für das } \\
\text { Kreditwesen of Germany. }\end{array}$ & Bilateral & 04-Sep-95 \\
\hline 114 & $\begin{array}{l}\text { Memorandum of Understanding on their Co-operation in the field of Banking Supervision after the implementation of the } \\
\text { second Banking Coordination Directive between the Finansinspektionen of Sweden and the Nederlandsche Bank NV of The } \\
\text { Netherlands. }\end{array}$ & Bilateral & 19-Sep-95 \\
\hline 115 & $\begin{array}{l}\text { Memorandum of Understanding concerning Consultation and Co-operation in the Administration and Enforcement of } \\
\text { Futures Laws between the Securities and Futures Commission of Hong Kong and the United States Commodity Futures } \\
\text { Trading Commission. }\end{array}$ & Bilateral & 05-Oct-95 \\
\hline 116 & $\begin{array}{l}\text { Collaboration agreement between Her Majesty's Treasury of the United Kingdom and the Commission bancaire et financière } \\
\text { of Belgium. }\end{array}$ & Bilateral & 01-Nov-95 \\
\hline 117 & $\begin{array}{l}\text { Memorandum of Understanding on the Exchange of Information between the Comisión Nacional de Valores of Argentina } \\
\text { and the Securities and Exchange Commission of Chinese Taipei. }\end{array}$ & Bilateral & 02-Nov-95 \\
\hline 118 & $\begin{array}{l}\text { Memorandum of Understanding concerning Consultation, Technical Assistance and Mutual Assistance on Consultation, } \\
\text { Tachnical Assistance and Mutual Assistance for the Exchange of Information between the Securities and Exchange } \\
\text { Commission of Thailand and the Superintendencia de Valores y Seguros of Chile. }\end{array}$ & Bilateral & 06-Nov-95 \\
\hline 119 & $\begin{array}{l}\text { Memorandum of Understanding concerning Co-operation and the Exchange of Information on regulation of Securities and } \\
\text { Futures Activities between the China Securities Regulatory Commission and the Monetary Authority of Singapore. }\end{array}$ & Bilateral & 30-Nov-95 \\
\hline 120 & $\begin{array}{l}\text { Memorandum of Understanding for Mutual Assistance and the Exchange of Information between the Securities and } \\
\text { Investment Board of The United Kingdom and the Commissione Nazionale per le Societá e la Borsa of Italy. }\end{array}$ & Bilateral & 01-Dec-95 \\
\hline 121 & $\begin{array}{l}\text { Memorandum of Understanding concerning technical cooperation, mutual assistance and consultation between the United } \\
\text { States Securities and Exchange Commission and the Federal Commission for the Securities Market of the Russian } \\
\text { Federation. }\end{array}$ & Bilateral & 05-Dec-95 \\
\hline 122 & $\begin{array}{l}\text { Memorandum of Understanding concerning Mutual Assistance and the Exchange of Information between the Securities and } \\
\text { Futures Commission of Hong Kong and the Securities and Exchange Commission of Chinese Taipei. }\end{array}$ & Bilateral & $07-F e b-96$ \\
\hline 123 & $\begin{array}{l}\text { Memorandum of Understanding concerning the Exchange of Information, Consultation and Technical Assistance between } \\
\text { the Capital Market Authority of Egypt and the Securities and Exchange Commission of the United States of America. }\end{array}$ & Bilateral & $11-F e b-96$ \\
\hline 124 & $\begin{array}{l}\text { Memorandum of Understanding concerning the Exchange of Information between the Securities and Futures Commission of } \\
\text { Hong Kong and the British Columbia Securities Commission. }\end{array}$ & Bilateral & 21-Feb-96 \\
\hline 125 & $\begin{array}{l}\text { Memorandum of Understanding concerning the Exchange of Information between the Comissão de Valores Mobiliários of } \\
\text { Brazil and the Commissione Nazionale per le Societá e la Borsa of Italy. }\end{array}$ & Bilateral & 06-Mar-96 \\
\hline 126 & $\begin{array}{l}\text { Memorandum of Understanding on Consultation, Technical Assistance and Mutual Assistance concerning the Exchange of } \\
\text { Information between the Comissão de Valores Mobiliários of Brazil and the Comisión Nacional del Mercado de Valores of } \\
\text { Spain. }\end{array}$ & Bilateral & 12-Mar-96 \\
\hline 127 & $\begin{array}{l}\text { Agreement concerning Technical Assistance and the Exchange of Information between the Comisión Nacional de Valores de } \\
\text { Peru and the United States Securities and Exchange Commission. }\end{array}$ & Bilateral & 01-Apr-96 \\
\hline 128 & $\begin{array}{l}\text { Memorandum of Understanding concerning the Exchange of Information between the Financial Services Board of South } \\
\text { Africa and the Securities and Futures Commission of Chinese Taipei. }\end{array}$ & Bilateral & 01-Apr-96 \\
\hline 129 & $\begin{array}{l}\text { Memorandum of Understanding between the British Columbia Securities Commission and the Australian Securities and } \\
\text { Investments Commission. }\end{array}$ & Bilateral & 11-Apr-96 \\
\hline 130 & $\begin{array}{l}\text { Administrative Agreement concerning the Exchange of Information between the Comissão do Mercado de Valores } \\
\text { Mobiliários of Portugal and the Commission des Opérations de Bourse of France. }\end{array}$ & Bilateral & 19-Apr-96 \\
\hline 131 & $\begin{array}{l}\text { Memorandum of Understanding concerning the Exchange of Information and Technical Assistance between the Comisión } \\
\text { Nacional Supervisora de Empresas y Valores of Peru and the Superintendencia de Valores of Colombia. }\end{array}$ & Bilateral & 01-May-96 \\
\hline 132 & $\begin{array}{l}\text { Memorandum of Understanding regarding Securities and Futures Regulatory Cooperation between the China Securities } \\
\text { Regulatory Commission and the Australian Securities and Investments Commission. }\end{array}$ & Bilateral & 23-May-96 \\
\hline 133 & $\begin{array}{l}\text { Memorandum of Understanding concerning the Exchange of Information and Technical Assistance between the Comisión } \\
\text { Nacional Supervisora de Empresas y Valores of Peru and the Superintendencia de Compañías of Ecuador. }\end{array}$ & Bilateral & 01-Jun-96 \\
\hline 134 & $\begin{array}{l}\text { Memorandum of Understanding to enhance the protection of investors and promote the integrity of the securities market } \\
\text { by providing a framework for Co-operation between the Securities and Exchange Commission of Thailand and the } \\
\text { Securities and Exchange Commission of Chinese Taipei. }\end{array}$ & Bilateral & 18-Jun-96 \\
\hline 135 & $\begin{array}{l}\text { Memorandum of Understanding on Mutual Assistance between the Comisión Nacional del Mercado de Valores of Spain and } \\
\text { the Comisión Nacional de Valores of Costa Rica. }\end{array}$ & Bilateral & 20-Jun-96 \\
\hline 136 & $\begin{array}{l}\text { Memorandum of Understanding concerning the Exchange of Information and Technical Assistance between the Comissão } \\
\text { de Valores Mobiliários of Brazil and the Superintendencia de Valores y Seguros of Chile. }\end{array}$ & Bilateral & 21-Jun-96 \\
\hline 137 & $\begin{array}{l}\text { Memorandum of Understanding concerning the Exchange of Information and Technical Assistance between the Comissão } \\
\text { de Valores Mobiliários of Brazil and the Superintendencia de Compañias of Ecuador. }\end{array}$ & Bilateral & 21-Jun-96 \\
\hline 138 & $\begin{array}{l}\text { Memorandum of Understanding concerning the Exchange of Information and Technical Assistance between the Comissão } \\
\text { de Valores Mobiliários of Brazil and the Comisión Nacional Supervisora de Empresas y Valores of Peru. }\end{array}$ & Bilateral & 21-Jun-96 \\
\hline 139 & $\begin{array}{l}\text { Agreement on the Exchange of Information between the Bundesaufsichtsamt für den Wertpapierhandel of Germany } \\
\text { (BAWe) and the Commission des Opérations de Bourse of France (COB). }\end{array}$ & Bilateral & $10-$ Sep-96 \\
\hline 140 & $\begin{array}{l}\text { Memorandum of Understanding between the United States Commodity Futures Trading Commission and the New Zealand } \\
\text { Securities Commission on Consultation and Mutual Assistance for the Exchange of Information. }\end{array}$ & Bilateral & $16-$ Sep-96 \\
\hline 141 & $\begin{array}{l}\text { Memorandum of Understanding between the Securities Commission of New Zealand and the Securities and Futures } \\
\text { Commission of Hong Kong concerning Mutual Assistance and Co-operation regarding the Protection of Investors and } \\
\text { Preservation of Market Integrity. }\end{array}$ & Bilateral & $17-$ Sep-96 \\
\hline 142 & $\begin{array}{l}\text { Memorandum of Understanding on Mutual Co-operation between the Comisión Nacional del Mercado de Valores of Spain } \\
\text { and the Securities and Futures Commission of Hong Kong. }\end{array}$ & Bilateral & 17-Sep-96 \\
\hline 143 & $\begin{array}{l}\text { Memorandum of Understanding between the Securities and Futures Commission of Chinese Taipei and the Capital Markets } \\
\text { Authority of Kenya. }\end{array}$ & Bilateral & 17-Sep-96 \\
\hline 144 & $\begin{array}{l}\text { Administrative Agreement concerning Mutual Consultation and Technical Assistance for the Exchange of Information } \\
\text { between the Commission des Valeurs Mobilières du Québec and the Superintendencia de Valores y Seguros of Chile. }\end{array}$ & Bilateral & 18-Sep-96 \\
\hline 145 & Memorandum of Understanding - September 19, 1996 (Alberta-Australia) & Bilateral & 19-Sep-96 \\
\hline 146 & $\begin{array}{l}\text { Memorandum of Understanding on Mutual Assistance and the Exchange of Information concerning regulatory Co-operation } \\
\text { in Securities and Futures Matters between Her Majesty's Treasury of the United Kingdom, the Securities and Investments } \\
\text { Board of the United Kingdom and the China Securities Regulatory Commission. }\end{array}$ & Bilateral & 07-Oct-96 \\
\hline 147 & $\begin{array}{l}\text { Memorandum of Understanding concerning the Exchange of Information and Mutual Consultation between the } \\
\text { Superintendencia de Valores y Seguros of Chile and the Financial Services Authority of the United Kingdom. }\end{array}$ & Bilateral & $15-$ Oct-96 \\
\hline & $\begin{array}{l}\text { Memorandum of Understanding on the Exchange of Information between the Securities Commission in Wellington, New } \\
\text { Zealand and the Securities and Exchange Commission of Chinese Taipei. }\end{array}$ & Bilateral & 04-De \\
\hline 149 & $\begin{array}{l}\text { Administrative Agreement on the Exchange of Information between the Capital Market Commission of Greece and the } \\
\text { United States Securities and Exchange Commission. }\end{array}$ & Bilateral & 23-Dec-96 \\
\hline 150 & $\begin{array}{l}\text { Memorandum of Understanding between the Monetary Authority of Singapore and the Securities and Futures Commission } \\
\text { of Hong Kong concerning the creation of a Framework for Co-operation, Mutual Understanding and the Exchange of } \\
\text { Information. }\end{array}$ & Bilateral & 16-Jan-97 \\
\hline
\end{tabular}




\begin{tabular}{|c|c|c|c|}
\hline & Acordos de Cooperação Requlatória & Tipo & Entrada em vigor \\
\hline 151 & $\begin{array}{l}\text { Memorandum of Understanding between the Capital Market Supervisory Agency of Indonesia and the Australian Securities } \\
\text { and Investments Commission. }\end{array}$ & Bilateral & 20-Feb-97 \\
\hline 152 & $\begin{array}{l}\text { Memorandum of Understanding regarding Mutual Assistance for the Exchange of Information between the Ontario } \\
\text { Securities Commission and the Hong Kong Securities and Futures Commission. }\end{array}$ & Bilateral & 25-Feb-97 \\
\hline 153 & $\begin{array}{l}\text { Bilateral Cooperation Agreement concerning Co-operation between the Capital Market Authority of Egypt and the Conseil } \\
\text { du Marché Financier of Tunisia. }\end{array}$ & Bilateral & 01-Mar-97 \\
\hline 154 & Memorandum of Understanding between the China Securities Regulatory Commission and the Ministry of Finance of Japan. & Bilateral & 18-Mar-97 \\
\hline 155 & $\begin{array}{l}\text { Memorandum of Understanding concerning the Exchange of Information and Technical Assistance between the Comissão } \\
\text { de Valores Mobiliários of Brazil and the Securities and Futures Commission of Hong Kong. }\end{array}$ & Bilateral & 30-Mar-97 \\
\hline 156 & $\begin{array}{l}\text { Memorandum of Understanding concerning Securities and Futures Regulatory Co-operation between the China Securities } \\
\text { Regulatory Commission and the Securities Commission of Malaysia. }\end{array}$ & Bilateral & 18-Apr-97 \\
\hline 157 & $\begin{array}{l}\text { Memorandum of Understanding concerning Mutual Assistance between the Securities and Futures Commission of Hong } \\
\text { Kong and the Commissione Nazionale per le Societá e la Borsa of Italy. }\end{array}$ & Bilateral & 30-May-97 \\
\hline 158 & $\begin{array}{l}\text { Memorandum of Understanding between the Securities Commission of Malaysia and the Capital Markets Authority of Kenya } \\
\text { concerning Mutual Assistance and Co-operation. }\end{array}$ & Bilateral & 09-Jun-97 \\
\hline 159 & $\begin{array}{l}\text { Memorandum of Understanding concerning Mutual Assistance and the Exchange of Information between the Federal } \\
\text { Securities Supervisory Office of Germany and the Comisión Nacional del Mercado de Valores of Spain. }\end{array}$ & Bilateral & 17-Jun-97 \\
\hline 160 & $\begin{array}{l}\text { Memorandum of Understanding concerning the Exchange of Information and Mutual Consultation between the } \\
\text { Superintendencia de Valores y Seguros of Chile and the Superintendencia de Valores of El Salvador. }\end{array}$ & Bilateral & 27-Jun-97 \\
\hline 161 & $\begin{array}{l}\text { Memorandum of Understanding concerning Consultation, Technical Assistance and Information Sharing between the } \\
\text { Superintendencia de Valores of El Salvador and the Comisión Nacional de Valores of Costa Rica. }\end{array}$ & Bilateral & 27-Jun-97 \\
\hline 162 & $\begin{array}{l}\text { Memorandum of Understanding concerning Mutual Co-operation and Assistance between the Commission des Opérations } \\
\text { de Bourse of France and the Conseil du Marché Financier of Tunisia. }\end{array}$ & Bilateral & 04-Jul-97 \\
\hline 163 & $\begin{array}{l}\text { Memorandum of Understanding concerning Mutual Assistance and the Exchange of Information between the Federal } \\
\text { Securities Supervisory Office of Germany and the Commissione Nazionale per le Societá e la Borsa of Italy. }\end{array}$ & Bilateral & $11-$ Sep-97 \\
\hline 164 & $\begin{array}{l}\text { Memorandum of Understanding between the Bank Supervision Department of the South African Reserve Bank and the } \\
\text { States of Jersey Financial Services Department on exchange of information regarding institutions that are subject to bank } \\
\text { supervision within each jurisdiction. }\end{array}$ & Bilateral & 02-Oct-97 \\
\hline 165 & $\begin{array}{l}\text { Memorandum of Understanding concerning Mutual Co-operation and Consultation between the Hungarian Banking and } \\
\text { Capital Market Supervision and the Commissariat aux Bourse of Luxembourg. }\end{array}$ & Bilateral & 07-Oct-97 \\
\hline 166 & $\begin{array}{l}\text { Memorandum of Understanding concerning the Exchange of Information and Technical Assistance between the Comissão } \\
\text { de Valores Mobiliários of Brazil and the Commission des Opérations de Bourse of France. }\end{array}$ & Bilateral & $10-$ Oct-97 \\
\hline 167 & $\begin{array}{l}\text { Memorandum of Understanding concerning mutual assistance And the exchange of information between the Comissão do } \\
\text { Mercado de Valores Mobiliários of Portugal and the United States Securities and Exchange Commisison. }\end{array}$ & Bilateral & $10-$ Oct-97 \\
\hline 168 & $\begin{array}{l}\text { Memorandum of Understanding concerning the Exchange of Information and Technical Assistance between the Comissão } \\
\text { de Valores Mobiliários of Brazil and the Office of the Securities and Exchange Commission of Thailand. }\end{array}$ & Bilateral & 31-Oct-97 \\
\hline 169 & $\begin{array}{l}\text { Memorandum of Understanding between the Securities Commission of Malaysia and the Financial Services Board of South } \\
\text { Africa concerning Mutual Assistance and Co-operation. }\end{array}$ & Bilateral & $31-$ Oct-97 \\
\hline 170 & $\begin{array}{l}\text { Memorandum of Understanding concerning Consultation and Technical Assistance between the Superintendencia de } \\
\text { Compañías of Ecuador and the Comisión Nacional del Mercado de Valores of Spain. }\end{array}$ & Bilateral & 04-Nov-97 \\
\hline 171 & $\begin{array}{l}\text { Memorandum of Understanding on the Exchange of Supervisory, Surveillance and Investigatory Information between the } \\
\text { Office of the Securities and Exchange Commission of Thailand and the Comisión Nacional de Valores of Argentina. }\end{array}$ & Bilateral & $06-N o v-97$ \\
\hline 172 & $\begin{array}{l}\text { Memorandum of Understanding concerning the Exchange of Information and Technical Assistance between the Comissão } \\
\text { de Valores Mobiliários of Brazil and the Australian Securities and Investments Commission. }\end{array}$ & Bilateral & $07-$ Nov-97 \\
\hline 173 & $\begin{array}{l}\text { Memorandum of Understanding concerning the Exchange of Information and Technical Assistance between the Comissão } \\
\text { de Valores Mobiliários of Brazil and the Securities Commission of Malaysia. }\end{array}$ & Bilateral & 07-Nov-97 \\
\hline 174 & $\begin{array}{l}\text { Memorandum of Understanding concerning the Exchange of Information and Technical Assistance between the Comissão } \\
\text { de Valores Mobiliários of Brazil and the Securities and Futures Commission of Chinese Taipei. }\end{array}$ & Bilateral & 07-Nov-97 \\
\hline 175 & $\begin{array}{l}\text { Memorandum of Understanding concerning Mutual Assistance and the Exchange of Supervisory, Surveillance and } \\
\text { Investigatory Information between the Federal Securities Supervisory Office of Germany and the Securities and Futures } \\
\text { Commission of Chinese Taipei }\end{array}$ & Bilateral & 07-Nov-97 \\
\hline 176 & $\begin{array}{l}\text { Memorandum of Understanding on the Exchange of Information between the Securities Commission of Malaysia and the } \\
\text { Securities and Futures Commission of Chinese Taipei. }\end{array}$ & Bilateral & 07-Nov-97 \\
\hline 177 & $\begin{array}{l}\text { Memorandum of Understanding on the Exchange of Information between the Comisión Nacional del Mercado de Valores of } \\
\text { Spain and the Securities and Futures Commission of Chinese Taipei. }\end{array}$ & Bilateral & 07-Nov-97 \\
\hline 178 & $\begin{array}{l}\text { Memorandum of Understanding concerning the Exchange of Information and Technical Assistance between the Comissão } \\
\text { de Valores Mobiliários of Brazil and the China Securities Regulatory Commission. }\end{array}$ & Bilateral & 13-Nov-97 \\
\hline 179 & $\begin{array}{l}\text { Memorandum of Understanding concerning the Exchange of Information and Technical Assistance between the Comissão } \\
\text { de Valores Mobiliários of Brazil and the Superintendencia de Valores of Bolivia. }\end{array}$ & Bilateral & $20-N o v-97$ \\
\hline 180 & $\begin{array}{l}\text { Memorandum of Understanding concerning Mutual Assistance between the Commission des Opérations de Bourse of France } \\
\text { and the Securities and Futures Commission of Hong Kong. }\end{array}$ & Bilateral & 20-Nov-97 \\
\hline 181 & $\begin{array}{l}\text { Memorandum of Understanding regarding Securities and Regulatory Co-operation between the China Securities Regulatory } \\
\text { Commission and the Ukrainian Securities and Stock Market State Commission. }\end{array}$ & Bilateral & 22-Dec-97 \\
\hline 182 & $\begin{array}{l}\text { Memorandum of Understanding on the Exchange of Information and Technical Assistance between the Superintendencia } \\
\text { General de Valores of Costa Rica and the Superintendencia de Pensiones, Valores y Seguros of Bolivia. }\end{array}$ & Bilateral & $14-\mathrm{Feb}-98$ \\
\hline 183 & $\begin{array}{l}\text { Memorandum of Understanding concerning Mutual Assistance and the Exchange of Information between the Federal } \\
\text { Securities Supervisory Office of Germany and the Securities and Futures Commission of Hong Kong. }\end{array}$ & Bilateral & 01-Mar-98 \\
\hline 184 & $\begin{array}{l}\text { Memorandum of Understanding concerning Mutual Cooperation and the Exchange of Information between the Federal } \\
\text { Securities Supervisory Office of Germany and the Australian Securities and Investments Commission. }\end{array}$ & Bilateral & 03-Mar-98 \\
\hline 185 & $\begin{array}{l}\text { Memorandum of Understanding regarding Securities and Futures Regulatory Co-operation between the China Securities } \\
\text { Regulatory Commission and the Commission des Opérations de Bourse of France. }\end{array}$ & Bilateral & 04-Mar-98 \\
\hline 186 & $\begin{array}{l}\text { Memorandum of Understanding concerning cooperation, consultation and technical assistance between the Securities and } \\
\text { Exchange Board (SEBI) of India and the United States Securities and Exchange Commission. }\end{array}$ & Bilateral & 06-Mar-98 \\
\hline 187 & $\begin{array}{l}\text { Memorandum of Understanding concerning the Exchange of Information and Technical Assistance between the Comissão } \\
\text { de Valores Mobiliários of Brazil and the Commission des Valeurs Mobilières du Québec. }\end{array}$ & Bilateral & 23-Mar-98 \\
\hline 188 & $\begin{array}{l}\text { Memorandum of Understanding concerning Mutual Co-operation and Assistance between the Commission des Opérations } \\
\text { de Bourse of France and the Conseil Deóntologique des Valeurs Mobilières of Morocco. }\end{array}$ & Bilateral & 09-Apr-98 \\
\hline 9 & $\begin{array}{l}\text { Memorandum of Understanding concerning Mutual Co-operation and the Exchange of Information between the Federal } \\
\text { Securities Supervisory Office of Germany and the Hungarian Financial Supervisory Authority. }\end{array}$ & Bilateral & 24-Apr-98 \\
\hline 190 & $\begin{array}{l}\text { Memorandum of Understanding regarding Securities and Futures Regulatory Co-operation between the China Securities } \\
\text { Regulatory Commission and the Commission de Surveillance du Secteur Financier of Luxembourg. }\end{array}$ & Bilateral & 18-May-98 \\
\hline 191 & Memorandum of Understanding between Malaysia and the Comisión Nacional de Valores of Argentina. & Bilateral & 21-May-98 \\
\hline 2 & $\begin{array}{l}\text { Memorandum of Understanding on Mutual Co-operation and the Exchange of Information between the Commission des } \\
\text { Valeurs Mobilières du Québec and the Securities and Futures Commission of Hong Kong. }\end{array}$ & Bilateral & $25-M$ \\
\hline 193 & $\begin{array}{l}\text { Memorandum of Understanding concerning Mutual Consultation and the Exchange of Information between the } \\
\text { Superintendencia de Valores y Seguros of Chile and the Securities Commission of Malaysia. }\end{array}$ & Bilateral & 26-May-98 \\
\hline 194 & $\begin{array}{l}\text { Memorandum of Understanding concerning the Exchange of Information between the Financial Services Board of South } \\
\text { Africa and the Superintendencia de Valores y Seguros of Chile. }\end{array}$ & Bilateral & 26-May-98 \\
\hline 195 & $\begin{array}{l}\text { Memorandum of Understanding concerning Mutual Consultation and the Exchange of Information between the } \\
\text { Superintendencia de Valores y Seguros of Chile and the Securities and Futures Commission of Taiwan. }\end{array}$ & Bilateral & 26-May-98 \\
\hline 196 & $\begin{array}{l}\text { Memorandum of Understanding concerning Mutual Co-operation and Assistance between the Commission des Opérations } \\
\text { de Bourse of France and the Superintendencia de Valores y Seguros of Chile. }\end{array}$ & Bilateral & 27-May-98 \\
\hline 197 & $\begin{array}{l}\text { Memorandum of Understanding between the Superintendencia de Pensiones, Valores y Seguros of Bolivia and the } \\
\text { Superintendencia de Valores y Seguros of Chile. }\end{array}$ & Bilateral & 04-Jun-98 \\
\hline 198 & $\begin{array}{l}\text { Memorandum of Understanding between the Superintendencia de Valores of El Salvador and the Comisión Nacional de } \\
\text { Supervisora de Empresas y Valores of Perú on Consultation and Technical Assistance }\end{array}$ & Bilateral & 15-Jun-98 \\
\hline 199 & $\begin{array}{l}\text { Convention on Mutual Co-operation and the Exchange of Information between the Commission des Opérations de Bourse } \\
\text { France and the Hungarian Financial Supervisory Authority. }\end{array}$ & ateral & 24-Jun-98 \\
\hline & $\begin{array}{l}\text { Memorandum of Understanding concerning Mutual Co-operation and the Exchange of Information between the Federal } \\
\text { Securities Supervisory Office of Germany and the Comissão do Mercado de Valores Mobiliários of Portugal. }\end{array}$ & Bilateral & 26-Jun-98 \\
\hline
\end{tabular}




\begin{tabular}{|c|c|c|c|}
\hline & Acordos de Cooperação Requlatória & Tipo & Entrada em vigor \\
\hline 201 & $\begin{array}{l}\text { Memorandum of Understanding concerning the Exchange of Information and Consultation between the Capital Market } \\
\text { Authority of Egypt and the Securities and Exchange Commission of Cyprus. }\end{array}$ & Bilateral & 30-Jun-98 \\
\hline 202 & $\begin{array}{l}\text { Memorandum of Understanding between the Securities Commission of Malaysia and the Australian Securities and } \\
\text { Investments Commission concerning Mutual Assistance and Co-operation. }\end{array}$ & Bilateral & 08-Jul-98 \\
\hline 203 & $\begin{array}{l}\text { Administrative Agreement on the Exchange of Information between the Capital Market Commission of Greece and the } \\
\text { Securities Market Commission of Portugal. }\end{array}$ & Bilateral & 09-Jul-98 \\
\hline 204 & $\begin{array}{l}\text { Memorandum of Understanding for the Exchange of Information and Investigative Assistance between the Securities } \\
\text { Commission of Papua New Guinea and the Securities Commission of New Zealand. }\end{array}$ & Bilateral & 22-Jul-98 \\
\hline 205 & $\begin{array}{l}\text { Memorandum of Understanding concerning Consultation and Technical Assistance between the Superintendencia de Valores } \\
\text { of El Salvador and the Superintendencia de Compañías de Ecuador. }\end{array}$ & Bilateral & 04-Aug-98 \\
\hline 206 & $\begin{array}{l}\text { Administrative Agreement on the Exchange of Information between the Capital Market Commission of Greece and the } \\
\text { Securities and Exchange Commission of Cyprus. }\end{array}$ & Bilateral & 01-Sep-98 \\
\hline 207 & $\begin{array}{l}\text { Memorandum of Understanding between the Finansinspektionen of Sweden and the Securities and Futures Commission of } \\
\text { Hong Kong concerning the Exchange of Information and Mutual Assistance. }\end{array}$ & Bilateral & 12-Sep-98 \\
\hline 208 & $\begin{array}{l}\text { Memorandum of Understanding concerning the Exchange of Information and Mutual Co-operation between the Commission } \\
\text { des valeurs mobilières du Québec and the Comsión Nacional del Mercado de Valores of Spain. }\end{array}$ & Bilateral & 14-Sep-98 \\
\hline 209 & $\begin{array}{l}\text { Memorandum of Understanding on Mutual Assistance and Co-operation between the Commissione Nazionale per le Societá } \\
\text { e la Borsa of Italy and the Hungarian Banking and Capital Market Supervision. }\end{array}$ & Bilateral & 14-Sep-98 \\
\hline 210 & $\begin{array}{l}\text { Memorandum of Understanding regarding Mutual Cooperation between the Commissione Nazionale per le Societá e la } \\
\text { Borsa of Italy and the Australian Securities and Investments Commission. }\end{array}$ & Bilateral & 15-Sep-98 \\
\hline 211 & $\begin{array}{l}\text { Memorandum of Understanding between the Financial Services Board of South Africa and the Securities and Futures } \\
\text { Commission of Hong Kong concerning Mutual Assistance and the Exchange of Information to Enforce or Secure Compliance } \\
\text { with any Laws or Regulations of these Jurisdictions. }\end{array}$ & Bilateral & 15-Sep-98 \\
\hline 212 & $\begin{array}{l}\text { Memorandum of Understanding concerning Mutual Co-operation and the Exchange of Information between the Federal } \\
\text { Securities Supervisory Office of Germany and the China Securities Regulatory Commission. }\end{array}$ & Bilateral & 08-Oct-98 \\
\hline 213 & $\begin{array}{l}\text { Memorandum of Understanding concerning Consultation and Technical Assistance between the Superintendencia de Valores } \\
\text { of El Salvador and the Superintendencia de Pensiones, Valores y Seguros of Bolivia. }\end{array}$ & Bilateral & $16-$ Oct-98 \\
\hline 214 & $\begin{array}{l}\text { Memorandum of Understanding on Consultation and Technical Assistance between the Superintendencia de Valores of } \\
\text { Colombia and the Superintendencia de Valores of El Salvador. }\end{array}$ & Bilateral & 23-Oct-98 \\
\hline 215 & $\begin{array}{l}\text { Memorandum of Understanding concerning Mutual Co-operation and the Exchange of Information between the } \\
\text { Bundesaufsichtsamt für den Wertpapierhandel of Germany (BAWe) and the Czech Securities Commission. }\end{array}$ & Bilateral & 05-Nov-98 \\
\hline 216 & $\begin{array}{l}\text { Memorandum of Understanding on the Exchange of Information and Mutual Assistance concerning matters of Securities } \\
\text { Supervision between the Austrian Securities Authority and the Hungarian Banking and Capital Market Supervision. }\end{array}$ & Bilateral & 16-Nov-98 \\
\hline 217 & $\begin{array}{l}\text { Memorandum of Understanding between the Superintendencia de Valores of El Salvador and the Comisión Nacional del } \\
\text { Mercado de Valores of Spain on Consultation and Technical Assistance. }\end{array}$ & Bilateral & 23-Nov-98 \\
\hline 218 & $\begin{array}{l}\text { Administrative Agreement on the Exchange of Information between the Capital Market Commission of Greece and the } \\
\text { Romanian National Securities Commission of Romania. }\end{array}$ & Bilateral & 30-Nov-98 \\
\hline 219 & Memorandum of Understanding between Germany and the Comisión Nacional de Valores of Argentina. & Bilateral & $18-$ Dec-98 \\
\hline 220 & $\begin{array}{l}\text { Agreement between the Bank of Mauritius and the Jersey Financial Services Commission on information sharing regarding } \\
\text { institutions for supervisory purposes. }\end{array}$ & Bilateral & 15-Jan-99 \\
\hline 221 & $\begin{array}{l}\text { Memorandum of Understanding between the Lithuanian Securities Commission, the Estonian Securities Inspectorate and } \\
\text { the Financial and Capital Market Commission of the Republic of Latvia on the Exchange of Information. }\end{array}$ & Bilateral & 21-Jan-99 \\
\hline 222 & $\begin{array}{l}\text { Multilateral Memorandum of Understanding on the exchange of information and surveillance of securities activities between } \\
\text { the following European authorities: }\end{array}$ & Multilateral & 26-Jan-99 \\
\hline 223 & $\begin{array}{l}\text { Multilateral Memorandum of Understanding on the exchange of information and surveillance of securities activities between } \\
\text { the following European authorities: }\end{array}$ & Multilateral & 26-Jan-99 \\
\hline 224 & $\begin{array}{l}\text { Memorandum of Understanding for the Exchange of Information and Investigative Assistance between the Securities } \\
\text { Commission of Papua New Guinea and the Australian Securities and Investments Commission. }\end{array}$ & Bilateral & 21-Feb-99 \\
\hline 225 & $\begin{array}{l}\text { Convention concerning the Exchange of Information between the Commission des Valeurs Mobilières du Québec and the } \\
\text { Conseil Deontologique des Valeurs Mobilières of Morocco. }\end{array}$ & Bilateral & 31-Mar-99 \\
\hline 226 & Administrative Agreement - April 01, 1999 & Bilateral & 01-Apr-99 \\
\hline 227 & $\begin{array}{l}\text { Protocol of Co-operation between the Capital Market Authority of Egypt and the Commission d'Organisations de Bourse of } \\
\text { Algeria. }\end{array}$ & Bilateral & 22-Apr-99 \\
\hline 228 & $\begin{array}{l}\text { Memorandum of Understanding between the Financial Services Board of the Republic of South Africa and the Australian } \\
\text { Securities and Investments Commission on the Exchange of Information for Co-operation and Consultation. }\end{array}$ & Bilateral & 01-May-99 \\
\hline 229 & $\begin{array}{l}\text { Memorandum of Understanding concerning Mutual Cooperation and Assistance between the Comissão de Valores } \\
\text { Mobiliários of Brazil and the Bundesaufsichtsamt für den Wertpapierhandel (Bawe), Germany. }\end{array}$ & Bilateral & 01-May-99 \\
\hline 230 & $\begin{array}{l}\text { Memorandum of Understanding on the Exchange of Information and Mutual Assistance concerning matters of Securities } \\
\text { Supervision between the Austrian Securities Authority and the Czech Securities Commission. }\end{array}$ & Bilateral & 03-May-99 \\
\hline 231 & $\begin{array}{l}\text { Memorandum of Understanding on the Exchange of Information between the Commission des Opérations de Bourse of } \\
\text { France and the Polish Securities and Exchange Commission. }\end{array}$ & Bilateral & 24-May-99 \\
\hline 232 & $\begin{array}{l}\text { Memorandum of Understanding between the Securities and Exchange Commission of Poland and the Bundesaufsichtsamt } \\
\text { für den Wartpapierhandel of Germany (BAWe). }\end{array}$ & Bilateral & 24-May-99 \\
\hline 233 & $\begin{array}{l}\text { Memorandum of Understanding between the Comisión Nacional del Mercado de Valores of Spain and the Australian } \\
\text { Securities and Investments Commission on the Exchange of Information and Mutual Assistance. }\end{array}$ & Bilateral & 25-May-99 \\
\hline 234 & $\begin{array}{l}\text { Memorandum of Understanding between the Securities and Exchange Commission of Poland and the Securities and } \\
\text { Exchange Commission of Argentina. }\end{array}$ & Bilateral & 26-May-99 \\
\hline 235 & Memorandum of Understanding between South Africa and the Comisión Nacional de Valores of Argentina. & Bilateral & 26-May-99 \\
\hline 236 & $\begin{array}{l}\text { Memorandum of Understanding between the Commissão de Valores Mobiliários of Portugal and the Securities and } \\
\text { Exchange Commission of Poland. }\end{array}$ & Bilateral & 27-May-99 \\
\hline 237 & $\begin{array}{l}\text { Memorandum of Understanding concerning Mutual Co-operation and the Exchange of Information between the Czech } \\
\text { Securities Commission and the Hungarian Financial Supervisory Authority. }\end{array}$ & Bilateral & 12-Sep-99 \\
\hline 238 & $\begin{array}{l}\text { Memorandum of Understanding between the Securities and Exchange Commission of Poland and the Czech Securities } \\
\text { Commission. }\end{array}$ & Bilateral & 12-Sep-99 \\
\hline 239 & $\begin{array}{l}\text { Memorandum of Understanding on Co-operation and the Exchange of Information between the Securities and Exchange } \\
\text { Commission of Poland and the Hungarian Banking and Capital Supervision. }\end{array}$ & Bilateral & 12-Sep-99 \\
\hline 240 & $\begin{array}{l}\text { Memorandum of Understanding between the Austrian Securities Authority and the Polish Securities and Exchange } \\
\text { Commission. }\end{array}$ & Bilateral & 13-Sep-99 \\
\hline 241 & $\begin{array}{l}\text { Memorandum of Understanding concerning Mutual Co-operation and Assistance between the Commission des Opérations } \\
\text { de Bourse of France and the Securities Commission of Malaysia. }\end{array}$ & Bilateral & 13-Sep-99 \\
\hline 242 & $\begin{array}{l}\text { Memorandum of Understanding on the Exchange of Information and Co-operation between the Comissão do Mercado de } \\
\text { Valores Mobiliários of Portugal and the Hungarian Banking and Capital Market Supervision. }\end{array}$ & Bilateral & 13-Sep-99 \\
\hline 243 & $\begin{array}{l}\text { Memorandum of Understanding between the London International Financial Futures Exchange (LIFFE) and the Comisión } \\
\text { Nacional del Mercado de Valores of Spain on the Exchange of Information relating to CNMV registered Investment Firms } \\
\text { which are or have applied to become Members of LIFFE. }\end{array}$ & Bilateral & 23-Sep-99 \\
\hline 244 & $\begin{array}{l}\text { Memorandum of Understanding concerning Mutual Co-operation and Assistance between the Commission des Opérations } \\
\text { de Bourse of France and the Conseil regional de l'épargne publique et des marches financiers of the West African Monetary } \\
\text { Union. }\end{array}$ & Plurilateral & 04-Oct-99 \\
\hline 245 & $\begin{array}{l}\text { Memorandum of Understanding on Consultation, Co-operation and the Exchange of Information between the Comissão do } \\
\text { Mercado de Valores Mobiliários of Portugal and the Financial Services Board of South Africa. }\end{array}$ & Bilateral & 19-Oct-99 \\
\hline 246 & $\begin{array}{l}\text { Memorandum of Understanding concerning Securities and Futures Regulatory Co-operation between the Commissione } \\
\text { Nazionale per le Societá e la Borsa of Italy and the China Securities Regulatory Commission. }\end{array}$ & Bilateral & 03-Nov-99 \\
\hline 247 & $\begin{array}{l}\text { Memorandum of Understanding concerning Mutual Co-operation and Assistance between the Commission des Opérations } \\
\text { de Bourse of France and the Monetary Authority of Singapore. }\end{array}$ & Bilateral & 23-Nov-99 \\
\hline 248 & $\begin{array}{l}\text { Memorandum of Understanding concerning Co-operation and Mutual Assistance between the Commission des Opérations } \\
\text { de Bourse of France and the Czech Securities Commission. }\end{array}$ & Bilateral & 07-Dec-99 \\
\hline 249 & $\begin{array}{l}\text { Memorandum of Understanding between the Bundesaufsichtsamt für das Kreditwesen and the Jersey Financial Services } \\
\text { Commission concerning their co-operation in the field of supervision of banks and investment firms. The authorities intend } \\
\text { to co-operate in the supervision of cross-border establishments of banks and investment firms incorporated in the } \\
\text { respective other country and within their respective jurisdiction. }\end{array}$ & Bilateral & $16-$ Feb-00 \\
\hline 250 & $\begin{array}{l}\text { Memorandum of Understanding between the Kredittilsynet of Norway, the Finansinspektionen of Sweden, the Financial } \\
\text { Supervision Authority of Finland, the Insurance Supervision Authority of Finland, the Financial Supervisory Authority of } \\
\text { Iceland, and the Financial Supervisory Authority of Denmark regarding co-operation concerning supervision of credit } \\
\text { institutions, insurance undertakings and investment firms. }\end{array}$ & Bilateral & $01-A p r-00$ \\
\hline
\end{tabular}




\begin{tabular}{|c|c|c|c|}
\hline & Acordos de Cooperação Requlatória & Tipo & Entrada em vigor \\
\hline 251 & $\begin{array}{l}\text { Memorandum of Understanding regarding Securities and Futures Regulatory Co-operation between the Commissione } \\
\text { Nazionale per le Societá e la Borsa of Italy and the Polish Securities and Exchange Commission. }\end{array}$ & Bilateral & 04-May-00 \\
\hline 252 & Memorandum of Understanding - May 14, 2000 Albania-Quebec & Bilateral & 14-May-00 \\
\hline 253 & US-Singapore (Enforcement Cooperation) & Bilateral & 15-May-00 \\
\hline 254 & $\begin{array}{l}\text { Memorandum of Understanding for Mutual Co-operation between the Commission des valeurs mobilières du Québec and } \\
\text { the Comisión Nacional de Valores of Argentina. }\end{array}$ & Bilateral & $16-$ May-00 \\
\hline 255 & $\begin{array}{l}\text { Memorandum of Understanding on the Exchange of Information and Mutual Assistance between the Monetary Authority of } \\
\text { Singapore and the Australian Securities and Investments Commission. }\end{array}$ & Bilateral & 16-May-00 \\
\hline 256 & Memorandum of Understanding between the Austrian Securities Authority and the Croatian Securities Commission. & Bilateral & 16-May-00 \\
\hline 257 & $\begin{array}{l}\text { Memorandum of Understanding on the Exchange of Information between the Turkish Capital Markets Board; SERMAYE } \\
\text { PIYASASI KURULU and the Bundesaufsichtsamt für den Wertpapierhandel of Germany (BAWe). }\end{array}$ & Bilateral & $16-$ May-00 \\
\hline 258 & $\begin{array}{l}\text { Memorandum of Understanding concerning the Exchange of Information between the Comissão do Valores Mobiliários of } \\
\text { Portugal and the Securities and Futures Commission of Hong Kong. }\end{array}$ & Bilateral & 16-May-00 \\
\hline 259 & $\begin{array}{l}\text { Memorandum of Understanding between the Comissão de Valores Mobiliários of Brazil and the Capital Market Commission } \\
\text { of Greece. }\end{array}$ & Bilateral & $17-M a y-00$ \\
\hline 260 & $\begin{array}{l}\text { Memorandum of Understanding on Mutual Assistance and the Exchange of Information between the Monetary Authority of } \\
\text { Singapore and the German Federal Securities Supervisory Office (BAWe). }\end{array}$ & Bilateral & 17-May-00 \\
\hline 261 & $\begin{array}{l}\text { Memorandum of Understanding between the Commission des Operations de Bourse of France and the Capital Markets } \\
\text { Board of Turkey on the Exchange of Information. }\end{array}$ & Bilateral & 18-May-00 \\
\hline 262 & $\begin{array}{l}\text { Memorandum of Understanding between the Danish Financial Supervisory Authority and the Financial and Capital Market } \\
\text { Commission of the Republic of Latvia on Co-operation in the field of Securities Market Supervision and the Exchange of } \\
\text { Information. }\end{array}$ & Bilateral & 25-May-00 \\
\hline 263 & Memorandum of Understanding - June 13, 2000 & Bilateral & 13-Jun-00 \\
\hline 264 & $\begin{array}{l}\text { Memorandum of Understanding regarding Securities Regulatory Co-operation between the Capital Market Authority of } \\
\text { Egypt and the China Securities Regulatory Commission (CSRC). }\end{array}$ & Bilateral & 22-Jun-00 \\
\hline 265 & $\begin{array}{l}\text { Memorandum of Understanding between the Rahoitustarkastus and the Bundesaufsichtsamt für das Kreditwesen } \\
\text { (BAWe)concerning their co-operation in the field of supervision after the implementation of the Second Banking } \\
\text { Coordination Directives and the Investment Services Directive of the European Commission. }\end{array}$ & Bilateral & 27-Jun-00 \\
\hline 266 & Memorandum of Understanding between El Salvador and the Comisión Nacional de Valores of Argentina. & Bilateral & 29-Jun-00 \\
\hline 267 & $\begin{array}{l}\text { Memorandum of Understanding between the Swedish Financial Supervisory Authority and the Financial and Capital Market } \\
\text { Commission of the Republic of Lativa on the Exchange of Information. }\end{array}$ & Bilateral & 17-Aug-00 \\
\hline 268 & $\begin{array}{l}\text { Memorandum of Understanding concerning Mutual Cooperation, Consultation and Assistance between the Comissão de } \\
\text { Valores Mobiliários of Brazil and the Commission de Surveillance du Secteur Financier of Luxembourg. }\end{array}$ & Bilateral & $06-\mathrm{Oct}-00$ \\
\hline 269 & $\begin{array}{l}\text { Memorandum of Understanding between the Secrutieis Market Agency of Slovenia and the Hellenic Capital Market } \\
\text { Commission on Mutual Co-operation and Exchange of Information. }\end{array}$ & Bilateral & $06-O c t-00$ \\
\hline 270 & $\begin{array}{l}\text { Memorandum of Understanding concerning Mutual Co-operation between the Comissão do Mercado de Valores Mobiliários } \\
\text { of Portugal and the Securities Market Agency of Slovenia. }\end{array}$ & Bilateral & $06-$ Oct-00 \\
\hline 271 & $\begin{array}{l}\text { Memorandum of Understanding for Mutual Co-operation and Assistance between the Commission des Opérations de Bourse } \\
\text { of France and the Lithuanian Securities Commission. }\end{array}$ & Bilateral & $09-0 c t-00$ \\
\hline 272 & $\begin{array}{l}\text { Memorandum of Understanding for Mutual Co-operation and Assistance between the Commission des Opérations de Bourse } \\
\text { of France and the Financial Services Board of South Africa. }\end{array}$ & Bilateral & $19-$ Oct-00 \\
\hline 273 & $\begin{array}{l}\text { Memorandum of Understanding between the Commission de Surveillance du Secteur Financier of Luxembourg and the } \\
\text { Financial Services Board of the Republic of South Africa on the Exchange of Information for Co-operation and Consultation. }\end{array}$ & Bilateral & 09-Nov-00 \\
\hline 274 & $\begin{array}{l}\text { Memorandum of Understanding on the Exchange of Information for Co-operation and Consultation between the Office of } \\
\text { the Securities and Exchange Commission of Thailand and the Financial Services Board of South Africa. }\end{array}$ & Bilateral & 19-Nov-00 \\
\hline 275 & $\begin{array}{l}\text { Administrative Agreement on the Exchange of Information between the Hellenic Capital Market Commission and the } \\
\text { Bulgarian National Securities Commission. }\end{array}$ & Bilateral & 01-Dec-00 \\
\hline 276 & $\begin{array}{l}\text { Memorandum of Understanding concerning Mutual Co-operation and the Exchange of Information between the Czech } \\
\text { Securities Commission and the Comissão do Mercado de Valores Mobiliários of Portugal. }\end{array}$ & Bilateral & 15 -Dec-00 \\
\hline 277 & Cooperation Agreement with the Banco de Cabo Verde and the Comissão do Mercado de Valores Mobiliários of Portugal. & Bilateral & 10-Jan-01 \\
\hline 278 & $\begin{array}{l}\text { Memorandum of Understanding concerning the Exchange of Information between the Cyprus Securities and Exchange } \\
\text { Commission and the Comissão do Mercado de Valores Mobiliários of Portugal. }\end{array}$ & Bilateral & 22-Jan-01 \\
\hline 279 & $\begin{array}{l}\text { Memorandum of Understanding between the Commission des Opérations de Bourse of France and the Commission } \\
\text { d'organisation et de surveillance des opérations de bourse of Algeria on Mutual Co-operation and the Exchange of } \\
\text { Information. }\end{array}$ & Bilateral & 25-Jan-01 \\
\hline 280 & $\begin{array}{l}\text { Memorandum of Understanding between the Comissão do Mercado de Valores Mobiliários of Portugal and the Comisia } \\
\text { Nationala a Valorilor Mobiliare of Rumania on the Exchange of Information. }\end{array}$ & Bilateral & 06-Feb-01 \\
\hline 281 & $\begin{array}{l}\text { Memorandum of Understanding between the Brazilian Securities and Exchange Commission and the Monetary Authority of } \\
\text { Singapore. }\end{array}$ & Bilateral & 22-Feb-01 \\
\hline 282 & $\begin{array}{l}\text { Memorandum of Understanding on the Exchange of Information and Mutual Co-operation between the Russian Securities } \\
\text { Supervisory Authority; Federalnaja Komissija Po Rinku Zennich Bumag and the Bundesaufsichtsamt für den } \\
\text { Wertpapierhandel of Germany (BAWe). }\end{array}$ & Bilateral & 15-Mar-01 \\
\hline 283 & Memorandum of Understanding between Portugal and the Comisión Nacional de Valores of Argentina. & Bilateral & 20-Mar-01 \\
\hline 284 & $\begin{array}{l}\text { Memorandum of Understanding between the Comissão do Mercado de Valores Mobiliários of Portugal and the Australian } \\
\text { Securities and Investments Commission on the Exchange of Information and Mutual Assistance. }\end{array}$ & Bilateral & 20-Mar-01 \\
\hline 285 & $\begin{array}{l}\text { Memorandum of Understanding between the Commission de Surveillance du Secteur Financier of Luxembourg and the } \\
\text { Securities Market Commission of the Republic of Latvia on the Exchange of Information. }\end{array}$ & Bilateral & 20-Mar-01 \\
\hline 286 & Memorandum of Understanding on the co-ordinated regulation, supervision and oversight of the Euronext Group. & Bilateral & 22-Mar-01 \\
\hline 287 & $\begin{array}{l}\text { Memorandum of Understanding between the Luxembourg Financial Supervisory Authority and the Financial and Capital } \\
\text { Market Commission on Co-operation in the field of Securities Market Supervision and the Exchange of Information. }\end{array}$ & Bilateral & 04-Apr-01 \\
\hline 288 & $\begin{array}{l}\text { Memorandum of Understanding between the Comisión Nacional de Valores of Argentina, the HM Treasury and the Financial } \\
\text { Services Authority of the United Kingdom. }\end{array}$ & Bilateral & 07-May-01 \\
\hline 289 & $\begin{array}{l}\text { Memorandum of Understanding between the Securities Commission of Malaysia, the Securities and Exchange Board of } \\
\text { India and the Government of the Republic of India. }\end{array}$ & Bilateral & 14-May-01 \\
\hline 290 & $\begin{array}{l}\text { Memorandum of Understanding concerning Mutual Co-operation and the Exchange of Information between the Securities } \\
\text { Market Agency of Slovenia and the Czech Securities Commission. }\end{array}$ & Bilateral & 31-May-01 \\
\hline 291 & $\begin{array}{l}\text { Agreement regarding Securities and Futures Regulatory Co-operation between the Financial Supervisory Commission of the } \\
\text { Republic of Korea and the China Securities Regulatory Commission. }\end{array}$ & Bilateral & 19-Jun-01 \\
\hline 292 & $\begin{array}{l}\text { Memorandum of Understanding concerning the Exchange of Information, Co-operation and Consultation between the } \\
\text { Comissão de Valores Mobiliários of Brazil and the Financial Services Board of the Republic of South Africa. }\end{array}$ & Bilateral & 25-Jun-01 \\
\hline 293 & $\begin{array}{l}\text { Memorandum of Understanding between the Monetary Authority of Singapore and the Commission des Valeurs Mobilières } \\
\text { du Québec on the Exchange of Information. }\end{array}$ & Bilateral & 25-Jun- 01 \\
\hline 294 & $\begin{array}{l}\text { Memorandum of Understanding concerning Mutual Co-operation and the Exchange of Information between the Czech } \\
\text { Securities Commission and the Commissione Nazionale per le Societá e la Borsa of Italy. }\end{array}$ & Bilateral & 25-Jun-01 \\
\hline 295 & $\begin{array}{l}\text { Memorandum of Understanding concerning Mutual Co-operation and the Exchange of Information between the Czech } \\
\text { Securities Commission and the Financial Market Authority of Slovakia. }\end{array}$ & Bilateral & 25 -Jun- 01 \\
\hline 296 & $\begin{array}{l}\text { Memorandum of Understanding regarding Securities and Futures Regulatory Cooperation between the Commissione } \\
\text { Nazionale per le Societa e la Borsa of Italy and the Capital Markets Board of Turkey. The Authorities will provide each other } \\
\text { the maximum possible assistance in order to facilitate their function to supervise the market. }\end{array}$ & Bilateral & 25-Jun-01 \\
\hline 297 & $\begin{array}{l}\text { Memorandum of Understanding on the Exchange of Information Between Finansinspektionen of Sweden and the Capital } \\
\text { Markets Board of Turkey. The Signatories will exchange supervisory, surveillance and investigators information in order to } \\
\text { assist each other in securing compliance with the laws, regulations and rules of both jurisdictions relating to securities and } \\
\text { futures markets. }\end{array}$ & Bilateral & 25-Jun-01 \\
\hline 298 & $\begin{array}{l}\text { Memorandum of Understanding between the United States Commodity Futures Trading Commission and the Capital } \\
\text { Markets Board of Turkey concerning Consultation and Cooperation and the Exchange of Information to enhance the } \\
\text { efficiency and integrity of the Futures Markets of the United States and Turkey; the protection of investors and customers; } \\
\text { appropriate market oversight etc. }\end{array}$ & Bilateral & 25-Jun-01 \\
\hline 299 & $\begin{array}{l}\text { Memorandum of Understanding between the Australian Securities and Investments Commission and the Capital Markets } \\
\text { Board of Turkey. }\end{array}$ & Bilateral & 26-Jun-01 \\
\hline 300 & $\begin{array}{l}\text { Memorandum of Understanding between the Securities Market Agency of Slovenia and the Austrian Securities Authori } \\
\text { Mutual Co-operation and the Exchange of Information. }\end{array}$ & Bilateral & 26-Jun-01 \\
\hline
\end{tabular}




\begin{tabular}{|c|c|c|c|}
\hline & Acordos de Cooperacãa Requlatória & Tipo & Entrada em vigor \\
\hline 301 & $\begin{array}{l}\text { Memorandum of Understanding between the Securities and Exchange Commission of Poland and the Securities Commission } \\
\text { of Malaysia. }\end{array}$ & Bilateral & 26-Jun-01 \\
\hline 302 & $\begin{array}{l}\text { Memorandum of Understanding on the Exchange of Information for Co-operation and Consultation between the Financial } \\
\text { Services Board of the Republic of South Africa and the Monetary Authority of Singapore. }\end{array}$ & Bilateral & 26-Jun-01 \\
\hline 303 & $\begin{array}{l}\text { Memorandum of Understanding between the Capital Markets Board of Turkey and the Malta Stock Exchange on the } \\
\text { Exchange of Information in order to protect investors and to promote the integrity of regulated markets by providing a } \\
\text { framework for cooperation, including channels for communication, increased mutual understanding, the exchange of } \\
\text { regulatory and technical information and investigative assistance. }\end{array}$ & Bilateral & 27-Jun-01 \\
\hline 304 & $\begin{array}{l}\text { Administrative Agreement on the Exchange of Information between the Capital Market Commission of Greece and the } \\
\text { Czech Securities Commission. }\end{array}$ & Bilateral & 28-Jun-01 \\
\hline 305 & $\begin{array}{l}\text { Memorandum of Understanding concerning Mutual Co-operation and the Exchange of Information between the Czech } \\
\text { Securities Commission and the Commission de Surveillance du Secteur Financier of Luxembourg. }\end{array}$ & Bilateral & 20-Jul-01 \\
\hline 306 & $\begin{array}{l}\text { Memorandum of Understanding between the Securities and Stock Market State Commission of Ukraine and the Federal } \\
\text { Commission for The Securities Market of the Russian Federation. }\end{array}$ & Bilateral & 18-Sep-01 \\
\hline 307 & $\begin{array}{l}\text { Memorandum of Understanding between the Superintendencia de Valores y Seguros of Chile and the Comissão do Mercado } \\
\text { de Valores Mobiliários of Portugal concerning the Exchange of Information and Mutual Assistance. }\end{array}$ & Bilateral & 20-Sep-01 \\
\hline 308 & Memorandum of Understanding between the Isle of Man Financial Supervision Commission and the Central Bank of Ireland. & Bilateral & 20-Sep-01 \\
\hline 309 & $\begin{array}{l}\text { Memorandum of Understanding concerning the Exchange of Information between the Malta Stock Exchange and the Cyprus } \\
\text { Securities and Exchange Commission. }\end{array}$ & Bilateral & 05-Oct-01 \\
\hline 310 & $\begin{array}{l}\text { Administrative Agreement on the Exchange of Information between the Capital Market Commission of Greece and the } \\
\text { Capital Markets Board of Turkey. }\end{array}$ & Bilateral & 05-Oct-01 \\
\hline 311 & $\begin{array}{l}\text { Memorandum of Understanding between the Financial Services Board of South Africa and the Bundesaufsichtsamt für den } \\
\text { Wertpapierhandel of Germany (BAWe) on the Exchange of Information and Mutual Co-operation. }\end{array}$ & Bilateral & 12-Oct-01 \\
\hline 312 & $\begin{array}{l}\text { Memorandum of Understanding on the Exchange of Information between the Capital Markets Board of Turkey and the } \\
\text { Comissão do Mercado de Valores Mobiliários of Portugal. }\end{array}$ & Bilateral & $12-$ Oct-01 \\
\hline 313 & $\begin{array}{l}\text { Memorandum of Understanding between the Securities and Exchange Commission of Poland and the Commission de } \\
\text { Surveillance du Secteur Financier of Luxembourg. }\end{array}$ & Bilateral & 25-Oct-01 \\
\hline 314 & $\begin{array}{l}\text { Memorandum of Understanding between the Polish Securities and Exchange Commission and the Financial and Capital } \\
\text { Market Commission of the Republic of Latvia concerning Co-operation and the Exchange of Information. }\end{array}$ & Bilateral & 05-Nov-01 \\
\hline 315 & $\begin{array}{l}\text { Memorandum of Understanding on the Exchange of Information for Co-operation and Consultation between the Office of } \\
\text { the Securities and Exchange Commission of Thailand and the Securities and Exchange Commission of Sri Lanka. }\end{array}$ & Bilateral & 19-Nov-01 \\
\hline 316 & $\begin{array}{l}\text { Memorandum of Understanding between the Commission des Opérations de Bourse of France and the Jersey Financial } \\
\text { Services Commission (JFSC) concerning Mutual Co-operation and the Exchange of Information. }\end{array}$ & Bilateral & 30-Nov-01 \\
\hline 317 & $\begin{array}{l}\text { Memorandum of Understanding between the Financial Services Agency of Japan and the Monetary Authority of Singapore } \\
\text { concerning Intensification of Co-operation in Sharing Information on Securities markets and Securities Derivatives Markets. }\end{array}$ & Bilateral & 21-Dec-01 \\
\hline 318 & $\begin{array}{l}\text { Memorandum of Understanding for Consultation and Co-operation between the Federal Commission for the Securities } \\
\text { Market of the Russian Federation and the Center on Coordination and Control of the Securities Market of the Republic of } \\
\text { Uzbekistan. }\end{array}$ & Bilateral & 21-Dec-01 \\
\hline 319 & $\begin{array}{l}\text { Memorandum of Understanding regarding Mutual Assistance and Co-operation between the Securities and Exchange } \\
\text { Commission of Sri Lanka and the Capital Market Supervisory Agency of Indonesia. }\end{array}$ & Bilateral & 04-Feb-02 \\
\hline 320 & $\begin{array}{l}\text { Memorandum of Understanding between the Securities Commission of Malaysia and the Securities and Exchange } \\
\text { Commission of Sri Lanka concerning Mutual Assistance and Co-operation. }\end{array}$ & Bilateral & 04-Feb-02 \\
\hline 321 & $\begin{array}{l}\text { Memorandum of Understanding between Finantsinspektsioon of Estonia and Rahoitustarkastus of Finland concerning their } \\
\text { co-operation in the field of securities supervision. }\end{array}$ & Bilateral & $08-F e b-02$ \\
\hline 322 & $\begin{array}{l}\text { Memorandum of Understanding between the Czech Securities Commission and the Cyprus Securities and Exchange } \\
\text { Commission on Mutual Co-operation and Exchange of Information. }\end{array}$ & Bilateral & 01-Mar-02 \\
\hline 323 & $\begin{array}{l}\text { Memorandum of Understanding between the Polish Securities and Exchange Commission and the Lithuanian Securities } \\
\text { Commission. }\end{array}$ & Bilateral & 01-Mar-02 \\
\hline 324 & $\begin{array}{l}\text { Agreement on the Exchange of Information between the Commission de Contrôle de la Gestion de Portefeuilles et des } \\
\text { Activités Boursières Assimilées of Monaco and the Commission des Opérations de Bourse of France. }\end{array}$ & Bilateral & 08-Mar-02 \\
\hline 325 & IOSCO Multilateral Memorandum of Understanding & Multilateral & 01-May-02 \\
\hline 326 & $\begin{array}{l}\text { Memorandum of Understanding between the Polish Securities and Exchange Commission and the Securities Market Agency } \\
\text { of Slovenia on cooperation and exchange of information. }\end{array}$ & Bilateral & 05-May-02 \\
\hline 327 & $\begin{array}{l}\text { Memorandum of Understanding on the Exchange of Information and Mutual Assistance on Matters of Securities Activities } \\
\text { Regulation between the Comisión Nacional del Mercado de Valores of Spain and the Czech Securities Commission. }\end{array}$ & Bilateral & 20-May-02 \\
\hline 328 & $\begin{array}{l}\text { Memorandum of Understanding between the Polish Securities and Exchange Commission and the Netherlands Authority for } \\
\text { the Financial Markets. }\end{array}$ & Bilateral & 21-May-02 \\
\hline 329 & $\begin{array}{l}\text { Memorandum of Understanding between the Securities Commission of New Zealand and the Securities and Exchange } \\
\text { Commission of Sri Lanka in relation to assistance and co-operation. }\end{array}$ & Bilateral & 21-May-02 \\
\hline 330 & $\begin{array}{l}\text { Memorandum of Understanding between the Securities Market Agency of Slovenia(SMA) and the Commissione Nazionale } \\
\text { per le Società e la Borsa (CONSOB) on mutual cooperation to facilitate supervisory functions. }\end{array}$ & Bilateral & 23-May-02 \\
\hline 331 & $\begin{array}{l}\text { Memorandum of Understanding between the Capital Market Supervisory Agency of Indonesia (BAPEPAM) and the Philippine } \\
\text { Securities and Exchange Commission on mutual cooperation in matters relating to the administration and enforcement of } \\
\text { the Philippine and Indonesian securities laws. }\end{array}$ & Bilateral & 05-Jun- 02 \\
\hline 332 & $\begin{array}{l}\text { Memorandum of Understanding concerning Exchange of Information and Assistance between the Capital Market Authority } \\
\text { of Egypt and the Commission des opérations de bourse of France. }\end{array}$ & Bilateral & 06-Sep-02 \\
\hline 333 & $\begin{array}{l}\text { Memorandum of Understanding between the Hellenic Capital Market Commission and the Financial Services Board of the } \\
\text { Republic of South Africa on the Exchange of Information for Co-operation and Consultation }\end{array}$ & Bilateral & 09-Oct-02 \\
\hline 334 & $\begin{array}{l}\text { Memorandum of Understanding in relation to Assistance and Mutual Cooperation between the Securities Commission of } \\
\text { Malaysia and the Jordan Securities Commission. }\end{array}$ & Bilateral & 31-Oct-02 \\
\hline 335 & $\begin{array}{l}\text { Memorandum of Understanding between the Jersey Financial Services Commission and the Bahrain Monetary Authority for } \\
\text { mutual assistance and the exchange of information for the purpose of enforcing and securing compliance with the } \\
\text { respective laws and regulations of each jurisdiction. }\end{array}$ & Bilateral & 03-Nov-02 \\
\hline 336 & $\begin{array}{l}\text { Memorandum of Understanding between the Securities and Exchange Board of India and the Financial Services } \\
\text { Commission of Mauritius on mutual co-operation to strengthen communication channels and establish a framework for } \\
\text { assistance }\end{array}$ & Bilateral & 12 -Dec-02 \\
\hline 337 & $\begin{array}{l}\text { Memorandum of Understanding between the Hellenic Capital Market Commission and the Hungarian Financial Supervisory } \\
\text { Authority on the Exchange of Information and Mutual Assistance concerning Matters of Securities Supervision }\end{array}$ & Bilateral & $08-\operatorname{Jan}-03$ \\
\hline 338 & $\begin{array}{l}\text { Memorandum of Understanding between the Securities and Exchange Board of India and the Securities and Exchange } \\
\text { Commission of Sri Lanka for assistance and mutual co-operation between the two agencies. }\end{array}$ & Bilateral & 23-Jan-03 \\
\hline 339 & $\begin{array}{l}\text { Memorandum of Understanding on Mutual Assistance and the Exchange of Information concerning matters of Securities } \\
\text { and Insurance Supervision between the Hungarian Financial Supervisory Authority and the Financial Market Authority of } \\
\text { the Slovak Republic }\end{array}$ & Bilateral & 27-Jan-03 \\
\hline 340 & $\begin{array}{l}\text { Memorandum of Understanding betweeen the Polish Securities and Exchange Commission and the Commission bancaire et } \\
\text { financière of Belgium. }\end{array}$ & Bilateral & 03-Mar-03 \\
\hline 341 & $\begin{array}{l}\text { Memorandum of Understanding regarding Securities and Futures Regulatory Co-operation between the China Securities } \\
\text { Regulatory Commission and the participating members of the Canadian Securities Administrators (Alberta Securities } \\
\text { Commission, the British Columbia Securities Commission, the Ontario Securities Commission, and the Commission des } \\
\text { valeurs mobilières du Québec) }\end{array}$ & Bilateral & 21-Mar-03 \\
\hline 342 & $\begin{array}{l}\text { Memorandum of Understanding regarding Securities and Futures Regulatory Co-operation between the China Securities } \\
\text { Regulatory Commission and the participating members of the Canadian Securities Administrators (Alberta Securities } \\
\text { Commission, the British Columbia Securities Commission, the Ontario Securities Commission, and the Commission des } \\
\text { valeurs mobilières du Québec) }\end{array}$ & Bilateral & 21-Mar-03 \\
\hline 343 & $\begin{array}{l}\text { Memorandum of Understanding between the Comissão do Mercado de Valores Mobiliários of Portugal and the "Úrad pre } \\
\text { financý trh (UFT), of the Slovak Republic. }\end{array}$ & Bilateral & 27-Jun-03 \\
\hline 344 & Memorandum of Understanding - August 01, 2003 & Bilateral & 01-Aug-03 \\
\hline 345 & $\begin{array}{l}\text { Memorandum of Understanding between the Polish Securities and Exchange Commission and the Hellenic Capital Market } \\
\text { Commission }\end{array}$ & Bilateral & 01-Aug-03 \\
\hline 346 & $\begin{array}{l}\text { Agreement of Cooperation between the Comissão do Mercado de Valores Mobiliários of Portugal and the Banco de } \\
\text { Mocambique. }\end{array}$ & Bilateral & $10-$ Sep-03 \\
\hline 347 & $\begin{array}{l}\text { Memorandum of Understanding concerning Mutual Assistance between the Office of Securities and Exchange Commission } \\
\text { of Thailand and the Capital Market Supervisory Agency of Indonesia. }\end{array}$ & Bilateral & 15 -Oct-03 \\
\hline 8 & $\begin{array}{l}\text { Memorandum of Understanding in relation to Assistance and Mutual Cooperation between the Securities Commission of } \\
\text { Malaysia and the Commissione Nazionale per le Società e la Borsa of Italy. }\end{array}$ & lateral & $17-0 c t-03$ \\
\hline 349 & $\begin{array}{l}\text { Memorandum of Understanding in relation to Assistance and Mutual Cooperation between the Securities Commission of } \\
\text { Malaysia and the Capital Market Authority of the Sultanate of Oman. }\end{array}$ & Bilateral & $17-0 c t-03$ \\
\hline 350 & $\begin{array}{l}\text { Memorandum of Understanding between the Securities Commission of Malaysia and the Commissione Nazionale per le } \\
\text { Società e la Borsa of Italy in relation to Assistance and Mutual Co-operation. }\end{array}$ & Bilateral & $18-0 c t-03$ \\
\hline
\end{tabular}




\begin{tabular}{|c|c|c|c|}
\hline & Acordos de Cooperação Requ & Tipo & Entrada em vigor \\
\hline 351 & $\begin{array}{l}\text { Memorandum of Understanding between the Romanian National Securities Commission and the Commissione Nazionale per } \\
\text { le Società e la Borsa of Italy on Mutual Cooperation and Exchange of Information. }\end{array}$ & Bilateral & 25 -Nov-03 \\
\hline 352 & $\begin{array}{l}\text { Memorandum of Understanding between the Commissione Nazionale per le Società e la Borsa of Italy and the Commission } \\
\text { de contrôle de la gestion de portefeuilles et des activités boursières assimilées de la Principauté de Monaco on Cooperation } \\
\text { and Exchange of Information. }\end{array}$ & Bilateral & $27-$ Nov- 03 \\
\hline 353 & $\begin{array}{l}\text { Memorandum of Understanding between the Securities and Exchange Commission of Pakistan and the Securities and } \\
\text { Exchange Commission of Sri Lanka in relation to Assistance and Mutual Cooperation. }\end{array}$ & Bilateral & 04-Dec-03 \\
\hline 354 & $\begin{array}{l}\text { Memorandum of Understanding between the China Securities Regulatory Commission and the New Zealand Securities } \\
\text { Commission regarding securities and futures regulatory cooperation. }\end{array}$ & Bilateral & 20-Feb-04 \\
\hline 355 & $\begin{array}{l}\text { Memorandum of Understanding between the Securities Commission of New Zealand and the Indonesian Capital Market } \\
\text { Supervisory Agency (BAPEPAM) in relation to mutual assistance and exchange of information. }\end{array}$ & Bilateral & $20-$ Feb- 04 \\
\hline 356 & $\begin{array}{l}\text { Memorandum of Understanding between the Securities Commission of Malaysia and the Securities Commission of New } \\
\text { Zealand in relation to assistance and mutual co-operation. }\end{array}$ & Bilateral & $20-F e b-04$ \\
\hline 357 & $\begin{array}{l}\text { Memorandum of Understanding on the Exchange of Information between the Capital Market Authority of Egypt and the } \\
\text { Commissione Nazionale per le Società e la Borsa of Italy. }\end{array}$ & Bilateral & 22-Feb-04 \\
\hline 358 & $\begin{array}{l}\text { Memorandum of Understanding on cooperation and exchange of information between the Mongolian Securities and } \\
\text { Exchange Commission and the Polish Securities and Exchange Commission. }\end{array}$ & Bilateral & 08-Mar-04 \\
\hline 359 & $\begin{array}{l}\text { Memorandum of Understanding in relation to consultation, cooperation and the exchange of information between the } \\
\text { Securities Commission of Malaysia and the Financial Supervisory Commission of Korea. }\end{array}$ & Bilateral & 17-Mar-04 \\
\hline 360 & $\begin{array}{l}\text { Agreement of Cooperation between the Malta Financial Services Authority and the Comissao do Mercado de Valores } \\
\text { Mobiliários of Portugal. }\end{array}$ & Bilateral & 23-Mar-04 \\
\hline 361 & $\begin{array}{l}\text { Agreement of Cooperation between the Comissao do Mercado de Valores Mobiliários of Portugal and the Malaysian } \\
\text { Securities Commission. }\end{array}$ & Bilateral & 19-May-04 \\
\hline 362 & $\begin{array}{l}\text { Memorandum of Understanding between the Securities and Exchange Commission of the Former Yugoslav Republic of } \\
\text { Macedonia and the Bulgarian Financial Supervision Commission on Mutual Assistance and the Exchange of Information } \\
\text { concerning matters of Securities supervision. }\end{array}$ & Bilateral & 25-Jun-04 \\
\hline 363 & $\begin{array}{l}\text { Memorandum of Understanding between the Croatian Securities Commission and the Securities and Exchange Commission } \\
\text { of the Former Yugoslav Republic of Macedonia on the Exchange of Information and Mutual Assistance concerning matters } \\
\text { of Securities Market supervision. }\end{array}$ & Bilateral & 25-Jun-04 \\
\hline 364 & $\begin{array}{l}\text { Agreement of Cooperation between the China Securities Regulatory Commission (CSRC) and the Comissão do Mercado de } \\
\text { Valores Mobiliários of Portugal. }\end{array}$ & Bilateral & 26-Oct-04 \\
\hline 365 & $\begin{array}{l}\text { Memorandum of Understanding between the Securities Commission of Malaysia and the Emirates Securities and } \\
\text { Commodities Autority (ESCA) of the United Arab Emirates in relation to assistance and mutual co-operation }\end{array}$ & Bilateral & 18-Mar-05 \\
\hline 366 & $\begin{array}{l}\text { Memorandum of Understanding on the Exchange of Information between the Netherlands Authority for the Financial } \\
\text { Markets (AFM) and the Capital Markets Board (Sermaye Piyasasi Kurulu) of Turkey }\end{array}$ & Bilateral & 13-Jun-05 \\
\hline 367 & $\begin{array}{l}\text { Memorandum of Understanding on the Exchange of Information and mutual assistance concerning matters of securities } \\
\text { supervision }\end{array}$ & Bilateral & 27-Jun-05 \\
\hline 368 & $\begin{array}{l}\text { Memorandum of Understanding between the Hellenic Capital Market Commission (HCMC) and the Israeli Securities } \\
\text { Authority (ISA) on the exchange of information and Surveillance of Securities activities }\end{array}$ & Bilateral & 27-Sep-05 \\
\hline 369 & $\begin{array}{l}\text { Memorandum of Understanding between the New Zealand Securities Commission (NSZC) and the Israel Securities } \\
\text { Authority (ISA) on the Exchange of Information and Surveillance of Securities Activities }\end{array}$ & Bilateral & $06-0 c t-05$ \\
\hline 370 & $\begin{array}{l}\text { Memorandum of Understanding between the Netherlands Authority for the Financial Markets (AFM) and Australian } \\
\text { Securities and Investments Commission (ASIC), recognising international activity in the financial markets, and the } \\
\text { corresponding need for cooperation between the relevant national authorities. }\end{array}$ & Bilateral & 18 -Nov-05 \\
\hline 371 & $\begin{array}{l}\text { Memorandum of Understanding between the Hellenic Capital Market Commission (HCMC) and the Securities Commission of } \\
\text { the Republic of Serbia on the exchange of information and mutual assistance concerning matters of securities supervision }\end{array}$ & Bilateral & 03-Dec-05 \\
\hline 372 & $\begin{array}{l}\text { Memorandum of Understanding between the Israel Securities Authority (ISA) and the Comissão do Mercado de Valores } \\
\text { Mobiliários of Portugal }\end{array}$ & Bilateral & 20-Dec-05 \\
\hline 373 & $\begin{array}{l}\text { Memorandum of Understanding between the Qatar Central Bank (QCB) and the Jersey Financial Services Commission } \\
\text { (JFSC) on the Exchange of Information for co-operation. }\end{array}$ & Bilateral & 16-Mar-06 \\
\hline 374 & US-Belgium (Regulatory Cooperation - Market Participants and Markets) & Bilateral & 26-Jun-06 \\
\hline 375 & $\begin{array}{l}\text { Memorandum of Understanding between the Securities Commission of Malaysia and the Dubai Financial Services Authority } \\
\text { (DFSA)on the exchange of information, co-operation and consultation. }\end{array}$ & Bilateral & 15-Aug-06 \\
\hline 376 & $\begin{array}{l}\text { Memorandum of Understanding between the Cayman Island Monetary Authority and the Jersey Financial Services } \\
\text { Commission on the Exchange of Information for co-operation and consultation }\end{array}$ & Bilateral & 21-Aug-06 \\
\hline 377 & $\begin{array}{l}\text { Agreement of cooperation between the Comissão do Mercado de Valores Mobiliarios (CMVM) of Portugal and the Comissão } \\
\text { do Mercado de Capitais (CMC) of Angola }\end{array}$ & Bilateral & 1-Sep-06 \\
\hline 378 & $\begin{array}{l}\text { Memorandum of Understanding between the Jersey Financial Services Commission and the Cyprus Securities and Exchange } \\
\text { Commission for mutual assistance and the exchange of information for the purpose of enforcing and securing compliance } \\
\text { with the respective laws of each jurisdiction. }\end{array}$ & Bilateral & 05-Feb- 07 \\
\hline 379 & $\begin{array}{l}\text { MEMORANDUM OF UNDERSTANDING BETWEEN THE STATE SECURITIES COMMISSION OF VIETNAM AND THE SECURITIES } \\
\text { COMMISSION OF MALAYSIA ON INFORMATION EXCHANGE AND MUTUAL ASSISTANCE. }\end{array}$ & Bilateral & $27-\mathrm{Feb}-07$ \\
\hline 380 & US-UK (Regulatory Cooperation - Isuers and Financial Reporting) & Bilateral & 01-Apr-07 \\
\hline 381 & $\begin{array}{l}\text { Memorandum of Understanding between the Hellenic Capital Market Commission (HCMC) and the Dubai Financ } \\
\text { Authority }\end{array}$ & Bilateral & 14-Sep-07 \\
\hline 382 & US-Bulgaria (Regulatory Cooperation - Isuers and Financial Reporting) & Bilateral & 01-May-08 \\
\hline 383 & $\begin{array}{l}\text { Memorandum of Understanding between the Jersey Financial Services Commission and the Central Bank of Oman to share } \\
\text { information and accomplish convergence towards common modalities and standards in cross-border supervision of banking } \\
\text { institutions and to establish a good working relationship to facilitate consolidated supervision. }\end{array}$ & Bilateral & 15-May-08 \\
\hline 384 & $\begin{array}{l}\text { Memorandum of Understanding between the Jersey Financial Services Commission and the Polish Financial Supervision } \\
\text { Authority to provide a formal basis for co-operation, including for the exchange of information and assistance in } \\
\text { enforcement matters. (Filed by the Jersey Financial Services Commission.) }\end{array}$ & Bilateral & 04-Nov-09 \\
\hline 385 & $\begin{array}{l}\text { Memorandum of Understanding on the Exchange of Information and Technical Assistance between the Comisión Nacional } \\
\text { de Valores of Panama and the Superintendencia de Valores of the Dominican Republic. }\end{array}$ & Bilateral & - \\
\hline
\end{tabular}


ANeXo II - ReSUltados DAS REgRESSÕeS.

\begin{tabular}{|c|c|c|c|c|c|c|c|c|}
\hline \multicolumn{9}{|c|}{ 01.índice de Precos ao Consumidor (2000 $=100)$} \\
\hline \multicolumn{2}{|l|}{ Parâmetros } & \multirow{2}{*}{$\begin{array}{l}i_{\text {i_co }} \mathbf{2 0 0 0 1 0 0} \\
j_{-} \text {co } 2000100\end{array}$} & \multirow{2}{*}{$\begin{array}{c}\text { Coef. } \\
0.1867139\end{array}$} & \multirow{2}{*}{$\begin{array}{c}\text { Std, Err. } \\
0.818595\end{array}$} & \multicolumn{2}{|c|}{$z \quad P>z$} & \multicolumn{2}{|c|}{ [ $95 \%$ Conf.Interval] } \\
\hline Tipo de regressão: & Random-effects GLS & & & & 0.23 & 0.820 & -1.417702 & 1.79113 \\
\hline \multirow[t]{2}{*}{ Variável agrupadora: } & Pares de países (par) & mablbk & 32.70562 & 1258.994 & 0.03 & 0.979 & -2434.878 & 2500.289 \\
\hline & & maplbk & 178.7066 & 332.4647 & 0.54 & 0.591 & -472.9122 & 830.3254 \\
\hline \multicolumn{2}{|l|}{$R$-quadrado: } & $m a m / b k$ & 2315.361 & 58.69056 & 39.45 & 0.000 & 2200.329 & 2430.392 \\
\hline - dentre & 0.0177 & mam/sc & -2095.244 & 58.72108 & -35.68 & 0.000 & -2210.335 & -1980.15 \\
\hline - entre & 0.0622 & $r c b l b k$ & 76.7249 & 2853630 & 0.00 & 1.000 & -5592934 & 5593088 \\
\hline \multirow[t]{2}{*}{ - geral } & 0.0196 & rcplbk & -705.7204 & 975.6689 & -0.72 & 0.469 & -2617.996 & 1206.556 \\
\hline & & $r c m / b k$ & 425.9536 & 36.41679 & 11.70 & 0.000 & 354.578 & 497.3292 \\
\hline Efeitos alearórios u_i: & Gaussianos & rcblsc & 223.5344 & 2853623 & 0.00 & 1.000 & -5592775 & 5593222 \\
\hline \multirow[t]{2}{*}{$\operatorname{corr}\left(u_{-} i\right)$ : } & 0 (assumido) & rcplsc & 250.8174 & 2853642 & 0.00 & 1.000 & -5592784 & 5593286 \\
\hline & & $h m m / b k$ & 35.80416 & 38.79717 & 0.92 & 0.356 & -40.23689 & 111.8452 \\
\hline Número de obs: & 221777 & hmblsc & -77.2534 & 2853635 & -0.00 & 1.000 & -5593099 & 5592944 \\
\hline Número de grupos: & 7921 & coblsc & -381.3063 & 336.8429 & -1.13 & 0.258 & -1041.506 & 278.8937 \\
\hline \multicolumn{2}{|l|}{ Observações por grupos: } & $\mathrm{com} / \mathrm{sc}$ & -300.5539 & 575.5257 & -0.52 & 0.602 & -1428.564 & 827.4556 \\
\hline$-\min$ & 9 & jxmablbk & -1.034055 & 11.93487 & -0.09 & 0.931 & -24.42598 & 22.35787 \\
\hline - mad & 28 & jxmaplbk & -4.020911 & 4.845219 & -0.83 & 0.407 & -13.51737 & 5.475544 \\
\hline \multirow[t]{2}{*}{$-\max$} & 36 & jxmam/bk & -0.007594 & 0.005662 & -1.34 & 0.180 & -0.018691 & 0.003504 \\
\hline & & $j \times m a m / s c$ & 0.0066786 & 0.005802 & 1.15 & 0.250 & -0.004694 & 0.018051 \\
\hline Wald chi2: & 4422.6 & $j x r c b l b k$ & -1.778538 & 25846.72 & -0.00 & 1.000 & -50660.42 & 50656.87 \\
\hline \multirow[t]{2}{*}{ Prob. > chiz: } & 0 & jxrcplbk & 6.429911 & 10.77135 & 0.60 & 0.551 & -14.68155 & 27.54137 \\
\hline & & jxrcm/bk & -0.001323 & 0.005865 & -0.23 & 0.822 & -0.012818 & 0.010172 \\
\hline sigma_u & 181.76454 & $j \times r c b l s c$ & -2.604197 & 25846.63 & -0.00 & 1.000 & -50661.07 & 50655.86 \\
\hline sigma_e & 5820.2861 & jxrcplsc & -0.109485 & 25846.89 & -0.00 & 1.000 & -50659.08 & 50658.86 \\
\hline \multirow{5}{*}{$\begin{array}{l}\text { rho (fração da variância } \\
\text { devido a } u \_i \text { ) }\end{array}$} & 0.00097433 & jxhmmlbk & -0.186415 & 0.818615 & -0.23 & 0.820 & -1.790872 & 1.418042 \\
\hline & & $j x h m b / s c$ & 1.968073 & 25846.79 & 0.00 & 1.000 & -50656.81 & 50660.75 \\
\hline & & jxcoblsc & 2.406666 & 3.675498 & 0.65 & 0.513 & -4.797178 & 9.61051 \\
\hline & & $j x c o m / s c$ & -0.255525 & 5.69324 & -0.04 & 0.964 & -11.41407 & 10.90302 \\
\hline & & cons & 20.47018 & 28.27932 & 0.72 & 0.469 & -34.95626 & 75.89663 \\
\hline
\end{tabular}

\begin{tabular}{|c|c|c|c|c|c|c|c|c|}
\hline \multicolumn{9}{|c|}{ 02.Inflação, precos ao consumidor (\%) } \\
\hline \multicolumn{2}{|l|}{ Parâmetros } & \multirow{2}{*}{${ }_{j \text { inflatio }}^{\text {i inflation }}$} & \multirow{2}{*}{$\begin{array}{l}\text { Coef. } \\
0.0047386\end{array}$} & \multirow{2}{*}{$\begin{array}{l}\text { Std. Err. } \\
0.004523\end{array}$} & \multirow{2}{*}{$\begin{array}{r}z \\
1.05\end{array}$} & \multirow{2}{*}{$\begin{array}{c}P>z \\
0.295\end{array}$} & \multicolumn{2}{|c|}{ [95\% Conf.Interval] } \\
\hline Tipo de regressão: & Random-effects GLS & & & & & & -0.004126 & 0.013603 \\
\hline \multirow[t]{2}{*}{ Variável agrupadora: } & Pares de países (par) & mablbk & 5.316225 & 20.49659 & 0.26 & 0.795 & -34.85635 & 45.4888 \\
\hline & & maplbk & -40.35046 & 25.62743 & -1.57 & 0.115 & -90.57931 & 9.878383 \\
\hline \multicolumn{2}{|l|}{$R$-quadrado: } & mamlbk & 208.1416 & 6.072313 & 34.28 & 0.000 & 196.2401 & 220.0432 \\
\hline - dentre & 0.018 & mamlsc & -202.5693 & 6.066499 & -33.39 & 90.000 & -214.4594 & -190.679 \\
\hline - entre & 0.036 & $r c b / b k$ & -19.3126 & 6496.934 & -0.00 & 0.998 & -12753.07 & 12714.44 \\
\hline \multirow[t]{2}{*}{ - geral } & 0.0185 & $r c p / b k$ & 9.44194 & 29.22488 & 0.32 & 0.747 & -47.83777 & 66.72165 \\
\hline & & $r c m / b k$ & -2.65087 & 3.819551 & -0.69 & 0.488 & -10.13705 & 4.835312 \\
\hline Efeitos alearórios u_i: & Gaussianos & rcblsc & 4.99009 & 6494.595 & 0.00 & 0.999 & -12724.18 & 12734.16 \\
\hline \multirow[t]{2}{*}{$\operatorname{corr}\left(u \_i\right)$ : } & 0 (assumido) & rcp/sc & 3.81598 & 6502.807 & 0.00 & 1.000 & -12741.45 & 12749.08 \\
\hline & & $h m m l b k$ & -0.112887 & 3.478027 & -0.03 & 0.974 & -6.929696 & 6.703921 \\
\hline Número de obs: & 217940 & hmblsc & 29.72288 & 6500.404 & 0.00 & 0.996 & -12710.84 & 12770.28 \\
\hline Número de grupos: & 7921 & coblsc & -26.97633 & 7.999772 & -3.37 & 0.001 & -42.65559 & -11.2971 \\
\hline \multicolumn{2}{|l|}{ Observações por grupos: } & $\mathrm{com} / \mathrm{sc}$ & -24.47257 & 8.206473 & -2.98 & 0.003 & -40.55696 & -8.38818 \\
\hline$-\min$ & 8 & $j x m a p / b k$ & -0.078714 & 2.564254 & -0.03 & 0.976 & -5.104559 & 4.947131 \\
\hline - mad & 27.5 & jxmamlbk & -0.010013 & 0.006672 & -1.50 & 0.133 & -0.02309 & 0.003064 \\
\hline \multirow[t]{2}{*}{$-\max$} & 36 & jxmablsc & -0.992295 & 3.417701 & -0.29 & 0.772 & -7.690865 & 5.706275 \\
\hline & & jxmamlsc & 0.0075388 & 0.006873 & 1.10 & 0.273 & -0.005932 & 0.02101 \\
\hline Wald chi2: & 4086.57 & jxrcblbk & -2.726026 & 1583.239 & -0.00 & 0.999 & -3105.818 & 3100.366 \\
\hline \multirow[t]{2}{*}{ Prob. > chi2: } & 0 & jxrcm/bk & -0.007259 & 0.006119 & -1.19 & 0.236 & -0.019251 & 0.004734 \\
\hline & & jxrcblsc & 1.444125 & 1582.533 & 0.00 & 0.999 & -3100.264 & 3103.152 \\
\hline sigma_u & 76.013323 & jxrcplsc & 9.181371 & 1586.565 & 0.01 & 0.995 & -3100.43 & 3118.793 \\
\hline sigma_e & 571.65468 & $j \times h m p / b k$ & -0.038124 & 4.660986 & -0.01 & 0.993 & -9.173489 & 9.097241 \\
\hline rho (fração da variância & 0.01737401 & jxhmmlbk & 0.0017014 & 0.007106 & 0.24 & 0.811 & -0.012225 & 0.015628 \\
\hline devido a $u \_i$ ) & & $j \times h m b / s c$ & -5.461923 & 1585.851 & -0.00 & 0.997 & -3113.673 & 3102.749 \\
\hline & & jxcoblsc & -0.020445 & 0.077566 & -0.26 & 0.792 & -0.172471 & 0.131581 \\
\hline & & jxcom/sc & -0.304676 & 1.191086 & -0.26 & 0.798 & -2.639161 & 2.029809 \\
\hline & & cons & 55.01624 & 2.222389 & 24.76 & 0.000 & 50.66043 & 59.37204 \\
\hline 3.Taxa & & & & & & & & \\
\hline Parâmetros & & i_official ue & Coef. & Std. Err. & $z$ & $P>z$ & {$[95 \%$ Conf } & Interval] \\
\hline Tipo de regressão: & Random-effects GLS & j_official e & 0.0355267 & 0.007447 & 4.77 & 0.000 & 0.0209317 & 0.050122 \\
\hline Variável agrupadora: & Pares de países (par) & mablbk & 106.4154 & 19.29478 & 5.52 & 0.000 & 68.59836 & 144.2325 \\
\hline & & maplbk & 51.59782 & 24.16542 & 2.14 & 0.033 & 4.234461 & 98.96117 \\
\hline$R$-quadrado: & & mamlbk & -682.1387 & 9.37591 & -72.7 & 50.000 & -700.5152 & -663.762 \\
\hline - dentre & 0.0829 & mamlsc & 669.403 & 9.437906 & 70.93 & 0.000 & 650.905 & 687.9009 \\
\hline - entre & 0.033 & rcblbk & -132.1208 & 586.019 & -0.23 & 0.822 & -1280.697 & 1016.455 \\
\hline - geral & 0.0526 & rcplbk & -243.2867 & 23.24629 & -10.4 & $\begin{array}{ll}70.000 \\
\end{array}$ & -288.8486 & -197.725 \\
\hline & & rcmlbk & 36.19292 & 6.11231 & 5.92 & 0.000 & 24.21301 & 48.17282 \\
\hline Efeitos alearórios u_i: & Gaussianos & rcblsc & 84.55141 & 676.829 & 0.12 & 0.901 & -1242.009 & 1411.112 \\
\hline corr $\left(u \_i\right)$ : & 0 (assumido) & rcplsc & 156.2371 & 868.19 & 0.18 & 0.857 & -1545.384 & 1857.858 \\
\hline & & hmmlbk & 331.7041 & 5.199385 & 63.80 & 0.000 & 321.5135 & 341.8947 \\
\hline Número de obs: & 239840 & hmblsc & -276.7129 & 557.6056 & -0.50 & 0.620 & -1369.6 & 816.174 \\
\hline Número de grupos: & 8100 & coblsc & 26.57121 & 12.56609 & 2.11 & 0.034 & 1.942122 & 51.2003 \\
\hline Observações por grupos: & & comlsc & -229.5902 & 9.956179 & -23.0 & $6 \quad 0.000$ & -249.1039 & -210.076 \\
\hline$-\min$ & 4 & jxmablbk & 0.0503837 & 0.012205 & 4.13 & 0.000 & 0.0264623 & 0.074305 \\
\hline - mad & 29.6 & jxmaplbk & -0.019909 & 0.042614 & -0.47 & 0.640 & -0.103431 & 0.063614 \\
\hline$-\max$ & 36 & jxmamlbk & 0.0285049 & 0.005694 & 5.01 & 0.000 & 0.0173442 & 0.039666 \\
\hline & & jxmamlsc & -0.046942 & 0.005922 & -7.93 & 0.000 & -0.058549 & -0.03534 \\
\hline Wald chi2: & 21187.36 & jxrcblbk & (dropped) & & & & & \\
\hline Prob. > chi2: & 0 & jxrcplbk & 0.5781104 & 0.460472 & 1.26 & 0.209 & -0.324397 & 1.480618 \\
\hline & & jxrcmlbk & -0.006947 & 0.003692 & -1.88 & 0.060 & -0.014183 & 0.000289 \\
\hline sigma_u & 1231.9884 & jxrcblsc & -184.9221 & 384.756 & -0.48 & 0.631 & -939.03 & 569.1858 \\
\hline sigma_e & 737.18095 & jxhmmlbk & -0.022111 & 0.006653 & -3.32 & 0.001 & -0.035149 & -0.00907 \\
\hline rho (fração da variância & 0.73635379 & jxhmplsc & 185.2961 & 384.7561 & 0.48 & 0.630 & -568.812 & 939.4042 \\
\hline devido a $u$ i) & & jxcoblsc & -0.010646 & 0.008865 & -1.20 & 0.230 & -0.028021 & 0.006729 \\
\hline & & jxcomlsc & 0.0400005 & 0.180303 & 0.22 & 0.824 & -0.313387 & 0.393388 \\
\hline & & cons & 101.1764 & 14.0579 & 7.20 & 0.000 & 73.62338 & 128.7293 \\
\hline
\end{tabular}




\begin{tabular}{|c|c|c|c|c|c|c|c|c|}
\hline Parâmetros & & i realeffenX & Coef. & Std. Err. & $z$ & $P>z$ & {$[95 \%$ Conf. } & Interval7 \\
\hline Tipo de regressão: & Random-effects GLS & j_realeffe $\sim x$ & -0.002316 & 0.003484 & -0.66 & 0.506 & -0.009144 & 0.004511 \\
\hline Variável agrupadora: & Pares de paises (par) & mablbk & -4131.434 & 27993.71 & -0.15 & 0.883 & -58998.09 & 50735.23 \\
\hline & & maplbk & -15229.93 & 21419.42 & -0.71 & 0.477 & -57211.23 & 26751.36 \\
\hline$R$-quadrado: & & mamlbk & 743.8406 & 14701.37 & 0.05 & 0.960 & -28070.32 & 29558 \\
\hline - dentre & 0.0222 & mamlsc & 1863.879 & 14952.49 & 0.12 & 0.901 & -27442.46 & 31170.21 \\
\hline - entre & 0.0194 & rcblbk & 7267.662 & 421984.5 & 0.02 & 0.986 & -819806.8 & 834342.1 \\
\hline - geral & 0.0219 & rcplbk & 20356.52 & 31108.15 & 0.65 & 0.513 & -40614.33 & 81327.37 \\
\hline & & rcmlbk & -1548.475 & 7340.415 & -0.21 & 0.833 & -15935.42 & 12838.47 \\
\hline Efeitos alearórios $u \_i$ : & Gaussianos & rcblsc & 3364.42 & 384284.3 & 0.01 & 0.993 & -749819 & 756547.8 \\
\hline corr $\left(u \_i\right)$ : & 0 (assumido) & rcplsc & -29796.23 & 444241.7 & -0.07 & 0.947 & -900494 & 840901.5 \\
\hline & & hmmlbk & -9483.819 & 4696.365 & -2.02 & 0.043 & -18688.52 & -279.113 \\
\hline Número de obs: & 82437 & hmblsc & 16430.76 & 406693.9 & 0.04 & 0.968 & -780674.6 & 813536.1 \\
\hline Número de grupos: & 3025 & coblsc & 468.6444 & 15484.21 & 0.03 & 0.976 & -29879.86 & 30817.15 \\
\hline Observações por grupos: & & comlsc & 250.7609 & 13118.89 & 0.02 & 0.985 & -25461.79 & 25963.32 \\
\hline$-\min$ & 10 & jxmablbk & 43.11197 & 256.403 & 0.17 & 0.866 & -459.4288 & 545.6527 \\
\hline - mad & 27.3 & jxmaplbk & 75.88796 & 203.3001 & 0.37 & 0.709 & -322.5729 & 474.3488 \\
\hline$-\max$ & 36 & jxmamlbk & -2.158781 & 140.5571 & -0.02 & 0.988 & -277.6455 & 273.328 \\
\hline & & jxmamlsc & -7.231549 & 143.1891 & -0.05 & 0.960 & -287.877 & 273.4139 \\
\hline Wald chi2: & 1851.81 & jxrcblbk & -73.53319 & 3760.427 & -0.02 & 0.984 & -7443.836 & 7296.769 \\
\hline Prob. > chi2: & 0 & jxrcplbk & -124.5453 & 288.3608 & -0.43 & 0.666 & -689.722 & 440.6314 \\
\hline & & jxrcmlbk & 5.874961 & 68.87909 & 0.09 & 0.932 & -129.1256 & 140.8755 \\
\hline sigma_u & 10284.66 & jxrcblsc & -38.66143 & 3456.354 & -0.01 & 0.991 & -6812.991 & 6735.668 \\
\hline sigma_e & 111253.63 & jxhmmlbk & 1.826066 & 43.6987 & 0.04 & 0.967 & -83.82181 & 87.47394 \\
\hline rho (fração da variância & 0.00847336 & jxhmblsc & -90.35036 & 3683.988 & -0.02 & 0.980 & -7310.834 & 7130.134 \\
\hline devido a u_i) & & jxcoblsc & -2.295045 & 146.9634 & -0.02 & 0.988 & -290.338 & 285.7479 \\
\hline & & jxcoplsc & 213.7757 & 3987.041 & 0.05 & 0.957 & -7600.681 & 8028.232 \\
\hline & & jxcomlsc & -0.69864 & 123.1434 & -0.01 & 0.995 & -242.0553 & 240.658 \\
\hline & & cons & 9443.407 & 677.0618 & 13.95 & 0.000 & 8116.39 & 10770.42 \\
\hline 05. Comércio de servi & (\% of PIB) & & & & & & & \\
\hline Parâmetros & & i_tradeins $p$ p & Coef. & Std. Err. & $z$ & $P>z$ & [95\% Conf. & Interval] \\
\hline Tipo de regressão: & Random-effects GLS & j_tradeins p & 0.0218743 & 0.002924 & 7.48 & 0.000 & 0.0161425 & 0.027606 \\
\hline Variável agrupadora: & Pares de países (par) & maplbk & -1.222447 & 0.276666 & -4.42 & 0.000 & -1.764703 & -0.68019 \\
\hline & & mamlbk & 0.7789596 & 0.103837 & 7.50 & 0.000 & 0.5754438 & 0.982476 \\
\hline$R$-quadrado: & & mablsc & 2.932185 & 0.2091 & 14.02 & 0.000 & 2.522357 & 3.342013 \\
\hline - dentre & 0.205 & mamlsc & 2.931008 & 0.103246 & 28.39 & 0.000 & 2.72865 & 3.133365 \\
\hline - entre & 0.0857 & rcblbk & 5.73682 & 21.0676 & 0.27 & 0.785 & -35.55491 & 47.02855 \\
\hline - geral & 0.0818 & rcplbk & 2.363442 & 0.295782 & 7.99 & 0.000 & 1.78372 & 2.943163 \\
\hline & & rcmlbk & 0.2161563 & 0.067139 & 3.22 & 0.001 & 0.0845664 & 0.347746 \\
\hline Efeitos alearórios $u \_i$ : & Gaussianos & rcblsc & -8.621594 & 20.67868 & -0.42 & 0.677 & -49.15107 & 31.90788 \\
\hline $\operatorname{corr}\left(u \_i\right):$ & 0 (assumido) & rcplsc & -28.37015 & 21.31096 & -1.33 & 0.183 & -70.13886 & 13.39856 \\
\hline & & hmmlbk & 2.789665 & 0.0571 & 48.86 & 0.000 & 2.677751 & 2.901578 \\
\hline Número de obs: & 198243 & hmblsc & 9.488722 & 20.90109 & 0.45 & 0.650 & -31.47666 & 50.45411 \\
\hline Número de grupos: & 7885 & coblsc & -1.196883 & 0.127816 & -9.36 & 0.000 & -1.447398 & -0.94637 \\
\hline Observações por grupos: & & comlsc & -0.168899 & 0.098107 & -1.72 & 0.085 & -0.361185 & 0.023387 \\
\hline$-\min$ & 1 & jxmablbk & -0.027378 & 0.00826 & -3.31 & 0.001 & -0.043568 & -0.01119 \\
\hline - mad & 25.1 & jxmaplbk & 0.0250961 & 0.016564 & 1.52 & 0.130 & -0.007368 & 0.05756 \\
\hline$-\max$ & 36 & jxmamlbk & -0.006762 & 0.00488 & -1.39 & 0.166 & -0.016326 & 0.002803 \\
\hline & & jxmamlsc & 0.0007574 & 0.004897 & 0.15 & 0.877 & -0.00884 & 0.010355 \\
\hline Wald chi2: & 49554.93 & jxrcblbk & -0.626939 & 2.611807 & -0.24 & 0.810 & -5.745987 & 4.492109 \\
\hline Prob. > chi2: & 0 & jxrcplbk & -0.044802 & 0.016735 & -2.68 & 0.007 & -0.077602 & -0.012 \\
\hline & & jxrcmlbk & -0.014118 & 0.003465 & -4.07 & 0.000 & -0.020909 & -0.00733 \\
\hline sigma_u & 9.0225957 & jxrcblsc & 0.5531871 & 2.591158 & 0.21 & 0.831 & -4.525389 & 5.631763 \\
\hline sigma_e & 4.4418721 & jxrcplsc & 2.10021 & 2.636387 & 0.80 & 0.426 & -3.067013 & 7.267433 \\
\hline rho (fração da variância & 0.80491672 & jxhmmlbk & 0.0056527 & 0.003196 & 1.77 & 0.077 & -0.000611 & 0.011917 \\
\hline devido a u_i) & & jxhmblsc & -0.974533 & 2.615859 & -0.37 & 0.709 & -6.101521 & 4.152456 \\
\hline & & jxcoblsc & -0.012627 & 0.007024 & -1.80 & 0.072 & -0.026393 & 0.001139 \\
\hline & & jxcomlsc & 0.0003809 & 0.004365 & 0.09 & 0.930 & -0.008174 & 0.008936 \\
\hline & & cons & 12.34302 & 0.110137 & 112.07 & $7 \quad 0.000$ & 12.12715 & 12.55888 \\
\hline 6.PIB (constante 2000 & US\$) & & & & & & & \\
\hline Parâmetros & & i_PIBconstns & Coef. & Std. Err. & $z$ & $P>z$ & [95\% Conf. & Interval] \\
\hline Tipo de regressão: & Random-effects GLS & j_PIBconst $\sim S$ & 0.0353098 & 0.004704 & 7.51 & 0.000 & 0.0260899 & 0.04453 \\
\hline Variável agrupadora: & Pares de países (par) & mablbk & $2.48 E+10$ & $7.57 E+09$ & 3.27 & 0.001 & $9.93 E+09$ & $3.96 E+10$ \\
\hline & & maplbk & $2.32 \mathrm{E}+09$ & $9.64 \mathrm{E}+09$ & 0.24 & 0.810 & $-1.66 \mathrm{E}+10$ & $2.12 \mathrm{E}+10$ \\
\hline$R$-quadrado: & & mamlbk & $9.73 E+09$ & $3.39 E+09$ & 2.87 & 0.004 & $3.08 \mathrm{E}+09$ & $1.64 \mathrm{E}+10$ \\
\hline - dentre & 0.1315 & mamlsc & $1.11 \mathrm{E}+11$ & $3.38 E+09$ & 32.88 & 0.000 & $1.05 E+11$ & $1.18 \mathrm{E}+11$ \\
\hline - entre & 0.0303 & rcblbk & $-4.19 E+12$ & $3.03 E+11$ & -13.81 & 10.000 & $-4.78 E+12$ & $-3.60 E+12$ \\
\hline - geral & 0.0402 & rcplbk & $-8.38 E+10$ & $1.07 E+10$ & -7.86 & 0.000 & $-1.05 E+11$ & $-6.29 E+10$ \\
\hline & & rcmlbk & $4.02 \mathrm{E}+10$ & $2.13 \mathrm{E}+09$ & 18.83 & 0.000 & $3.60 E+10$ & $4.44 \mathrm{E}+10$ \\
\hline Efeitos alearórios $u \_i$ : & Gaussianos & rcblsc & $4.12 \mathrm{E}+12$ & $2.87 E+11$ & 14.35 & 0.000 & $3.56 \mathrm{E}+12$ & $4.68 \mathrm{E}+12$ \\
\hline corr $\left(u \_i\right)$ : & 0 (assumido) & rcplsc & $-5.47 E+10$ & $3.32 \mathrm{E}+11$ & -0.16 & 0.869 & $-7.05 E+11$ & $5.96 \mathrm{E}+11$ \\
\hline & & hmmlbk & $6.99 E+10$ & $1.75 \mathrm{E}+09$ & 39.84 & 0.000 & $6.65 \mathrm{E}+10$ & $7.33 E+10$ \\
\hline Número de obs: & 248587 & hmblsc & $-5.72 E+11$ & $3.02 \mathrm{E}+11$ & -1.89 & 0.058 & $-1.16 \mathrm{E}+12$ & $2.05 E+10$ \\
\hline Número de grupos: & 8100 & coblsc & $2.18 \mathrm{E}+11$ & $4.85 \mathrm{E}+09$ & 44.97 & 0.000 & $2.09 \mathrm{E}+11$ & $2.28 \mathrm{E}+11$ \\
\hline Observações por grupos: & & comlsc & $1.14 \mathrm{E}+11$ & $3.53 E+09$ & 32.22 & 0.000 & $1.07 \mathrm{E}+11$ & $1.21 \mathrm{E}+11$ \\
\hline$-\min$ & 6 & jxmablbk & -0.031224 & 0.004939 & -6.32 & 0.000 & -0.040904 & -0.02154 \\
\hline - mad & 30.7 & jxmaplbk & -0.002634 & 0.005708 & -0.46 & 0.644 & -0.013821 & 0.008553 \\
\hline$-\max$ & 36 & jxmamlbk & -0.000868 & 0.002509 & -0.35 & 0.729 & -0.005785 & 0.004049 \\
\hline & & jxmamlsc & -0.017235 & 0.002546 & -6.77 & 0.000 & -0.022224 & -0.01225 \\
\hline Wald chi2: & 36580.16 & jxrcblbk & -0.5558 & 0.347861 & -1.60 & 0.110 & -1.237595 & 0.125995 \\
\hline Prob. > chi2: & 0 & jxrcplbk & -0.0315 & 0.011063 & -2.85 & 0.004 & -0.053183 & -0.00982 \\
\hline & & jxrcmlbk & -0.004786 & 0.00194 & -2.47 & 0.014 & -0.008587 & -0.00098 \\
\hline sigma_u & $8.938 \mathrm{E}+11$ & jxrcblsc & -0.340208 & 0.035249 & -9.65 & 0.000 & -0.409295 & -0.27112 \\
\hline sigma_e & $2.699 \mathrm{E}+11$ & jxrcplsc & 1.942967 & 0.34873 & 5.57 & 0.000 & 1.25947 & 2.626465 \\
\hline rho (fração da variância & 0.91646024 & jxhmmlbk & -0.022193 & 0.002263 & -9.81 & 0.000 & -0.026629 & -0.01776 \\
\hline devido a u_i) & & jxhmblsc & 0.0037108 & 0.03805 & 0.10 & 0.922 & -0.070865 & 0.078287 \\
\hline & & jxcoblsc & 0.0210347 & 0.002271 & 9.26 & 0.000 & 0.0165844 & 0.025485 \\
\hline & & jxcomlsc & 0.0034248 & 0.002077 & 1.65 & 0.099 & -0.000647 & 0.007496 \\
\hline & & cons & $1.90 \mathrm{E}+11$ & $1.01 \mathrm{E}+10$ & 18.86 & 0.000 & $1.70 \mathrm{E}+11$ & $2.10 \mathrm{E}+11$ \\
\hline
\end{tabular}




\begin{tabular}{|c|c|c|c|c|c|c|c|c|}
\hline \multicolumn{2}{|l|}{ Parâmetros } & \multirow{2}{*}{\begin{tabular}{|l|} 
i_PIBgrowt I \\
j_PIBgrowt 1
\end{tabular}} & \multirow{2}{*}{$\frac{\text { Coef. }}{0.0736757}$} & \multirow{2}{*}{$\frac{\text { Std, Err. }}{0.002992}$} & \multirow{2}{*}{$\frac{z}{24.62}$} & \multirow{2}{*}{$\frac{P>z}{0.000}$} & \multicolumn{2}{|c|}{ [95\% Conf.Interval] } \\
\hline Tipo de regressão: & Random-effects GLS & & & & & & 0.0678106 & 0.079541 \\
\hline \multirow[t]{2}{*}{ Variável agrupadora: } & Pares de países (par) & mablbk & 0.2644706 & 0.182238 & 1.45 & 0.147 & -0.09271 & 0.621651 \\
\hline & & maplbk & -0.168625 & 0.189351 & -0.89 & 0.373 & -0.539748 & 0.202497 \\
\hline \multicolumn{2}{|l|}{$R$-quadrado: } & mamlbk & -0.61281 & 0.07905 & -7.75 & 0.000 & -0.767745 & -0.45787 \\
\hline - dentre & 0.0272 & mamlsc & 0.9895845 & 0.078279 & 12.64 & 0.000 & 0.836161 & 1.143008 \\
\hline - entre & 0.0007 & rcblbk & -2.158299 & 6.981591 & -0.31 & 0.757 & -15.84197 & 11.52537 \\
\hline \multirow[t]{2}{*}{ - geral } & 0.0226 & rcplbk & -0.46982 & 0.218234 & -2.15 & 0.031 & -0.89755 & -0.04209 \\
\hline & & rcmlbk & 0.3034632 & 0.041201 & 7.37 & 0.000 & 0.222711 & 0.384215 \\
\hline Efeitos alearórios u_i: & Gaussianos & rcblsc & 1.554592 & 6.833744 & 0.23 & 0.820 & -11.8393 & 14.94848 \\
\hline \multirow[t]{2}{*}{ corr $\left(u \_i\right)$ : } & 0 (assumido) & hmmlbk & 0.1033538 & 0.029879 & 3.46 & 0.001 & 0.0447928 & 0.161915 \\
\hline & & hmblsc & -3.752572 & 7.025596 & -0.53 & 0.593 & -17.52249 & 10.01734 \\
\hline Número de obs: & 247510 & coblsc & -0.817451 & 0.099083 & -8.25 & 0.000 & -1.011649 & -0.62325 \\
\hline Número de grupos: & 8100 & coplsc & 1.791396 & 7.175763 & 0.25 & 0.803 & -12.27284 & 15.85563 \\
\hline \multicolumn{2}{|l|}{ Observações por grupos: } & comlsc & 0.0151029 & 0.093365 & 0.16 & 0.871 & -0.167889 & 0.198094 \\
\hline$-\min$ & 12 & jxmablbk & -0.085971 & 0.040379 & -2.13 & 0.033 & -0.165111 & -0.00683 \\
\hline - mad & 30.6 & jxmaplbk & 0.1517131 & 0.045083 & 3.37 & 0.001 & 0.0633529 & 0.240073 \\
\hline \multirow[t]{2}{*}{$-\max$} & 36 & jxmamlbk & 0.0043375 & 0.014586 & 0.30 & 0.766 & -0.02425 & 0.032925 \\
\hline & & jxmamlsc & 0.0302969 & 0.014517 & 2.09 & 0.037 & 0.0018432 & 0.058751 \\
\hline Wald chi2: & 6516.73 & jxrcblbk & 1.27935 & 2.542342 & 0.50 & 0.615 & -3.703548 & 6.262248 \\
\hline \multirow[t]{2}{*}{ Prob. > chi2: } & 0 & jxrcplbk & 0.059151 & 0.055081 & 1.07 & 0.283 & -0.048806 & 0.167108 \\
\hline & & jxrcmlbk & -0.045162 & 0.006952 & -6.50 & 0.000 & -0.058788 & -0.03154 \\
\hline sigma_u & 1.3852061 & jxrcblsc & -1.05801 & 2.515494 & -0.42 & 0.674 & -5.988287 & 3.872268 \\
\hline sigma_e & 4.5312754 & jxrcplsc & -1.120563 & 2.588292 & -0.43 & 0.665 & -6.193522 & 3.952396 \\
\hline rho (fração da variância & 0.08546499 & jxhmmlbk & 0.0270894 & 0.004291 & 6.31 & 0.000 & 0.0186802 & 0.035499 \\
\hline \multirow[t]{4}{*}{ devido a u_i) } & & jxhmblsc & 1.575269 & 2.561189 & 0.62 & 0.539 & -3.444569 & 6.595107 \\
\hline & & jxcoblsc & 0.0890932 & 0.019548 & 4.56 & 0.000 & 0.0507801 & 0.127406 \\
\hline & & jxcomlsc & 0.0197291 & 0.018756 & 1.05 & 0.293 & -0.017033 & 0.056491 \\
\hline & & cons & 2.957615 & 0.023346 & 126.6 & $\begin{array}{ll}9 & 0.000\end{array}$ & 2.911859 & 3.003372 \\
\hline
\end{tabular}

\begin{tabular}{|c|c|c|c|c|c|c|c|c|}
\hline \multicolumn{9}{|c|}{ 8.PIB per capita (constante 2000 US\$) } \\
\hline \multicolumn{2}{|l|}{ Parâmetros } & \multirow{2}{*}{$\begin{array}{l}\text { I_PIBperca s } \\
\text { j_PIBperca s }\end{array}$} & \multirow{2}{*}{$\begin{array}{c}\text { Coef: } \\
0.1080497\end{array}$} & \multirow{2}{*}{$\begin{array}{l}\text { Std. Err. } \\
0.003167\end{array}$} & \multirow{2}{*}{$\begin{array}{c}z \\
34.11\end{array}$} & \multirow{2}{*}{$\begin{array}{l}P>z \\
0.000\end{array}$} & \multicolumn{2}{|c|}{ [95\% Conf.Interval] } \\
\hline Tipo de regressão: & Random-effects GLS & & & & & & 0.101842 & 0.114258 \\
\hline \multirow[t]{2}{*}{ Variável agrupadora: } & Pares de países (par) & mablbk & 1358.307 & 91.37797 & 14.86 & 0.000 & 1179.21 & 1537.405 \\
\hline & & maplbk & -502.7351 & 129.7318 & -3.88 & 0.000 & -757.0048 & -248.465 \\
\hline \multicolumn{2}{|l|}{ R-quadrado: } & mamlbk & 2018.693 & 30.59987 & 65.97 & 0.000 & 1958.719 & 2078.668 \\
\hline - dentre & 0.4103 & mamlsc & 1127.687 & 30.53983 & 36.93 & 0.000 & 1067.83 & 1187.544 \\
\hline - entre & 0.0654 & rcblbk & -4169.92 & 6800.931 & -0.61 & 0.540 & -17499.5 & 9159.66 \\
\hline \multirow[t]{2}{*}{ - geral } & 0.0887 & rcmlbk & 581.6323 & 18.93017 & 30.73 & 0.000 & 544.5298 & 618.7347 \\
\hline & & rcblsc & 10400.57 & 6594.808 & 1.58 & 0.115 & -2525.015 & 23326.16 \\
\hline Efeitos alearórios u_i: & Gaussianos & hmplbk & 1259.398 & 156.1616 & 8.06 & 0.000 & 953.3272 & 1565.47 \\
\hline \multirow{2}{*}{ corr $\left(u \_i\right)$ : } & 0 (assumido) & hmmlbk & 1204.211 & 15.26554 & 78.88 & 0.000 & 1174.291 & 1234.131 \\
\hline & & hmblsc & -3897.766 & 6880.171 & -0.57 & 0.571 & -17382.65 & 9587.121 \\
\hline Número de obs: & 248587 & hmplsc & -14333.26 & 7126.578 & -2.01 & 0.044 & -28301.1 & -365.423 \\
\hline Número de grupos: & 8100 & coblsc & -626.3214 & 49.68665 & -12.6 & 10.000 & -723.7055 & -528.937 \\
\hline \multicolumn{2}{|l|}{ Observações por grupos: } & comlsc & 722.1104 & 35.46154 & 20.36 & 0.000 & 652.607 & 791.6137 \\
\hline$-\min$ & 6 & jxmablbk & -0.03328 & 0.004643 & -7.17 & 0.000 & -0.04238 & -0.02418 \\
\hline - mad & 30.7 & jxmaplbk & 0.0027619 & 0.008037 & 0.34 & 0.731 & -0.01299 & 0.018514 \\
\hline \multirow[t]{2}{*}{$-\max$} & 36 & jxmamlbk & -0.011257 & 0.00208 & -5.41 & 0.000 & -0.015333 & -0.00718 \\
\hline & & jxmamlsc & -0.013197 & 0.002079 & -6.35 & 0.000 & -0.017271 & -0.00912 \\
\hline Wald chi2: & 166529.61 & jxrcblbk & -0.170999 & 0.22752 & -0.75 & 0.452 & -0.61693 & 0.274933 \\
\hline \multirow[t]{2}{*}{ Prob. > chiz: } & 0 & jxrcplbk & 0.0514385 & 0.008793 & 5.85 & 0.000 & 0.0342042 & 0.068673 \\
\hline & & jxrcmlbk & 0.000764 & 0.001527 & 0.50 & 0.617 & -0.002228 & 0.003756 \\
\hline sigma_u & 7650.5867 & jxrcblsc & -0.223568 & 0.205764 & -1.09 & 0.277 & -0.626858 & 0.179721 \\
\hline sigma_e & 1972.0924 & jxrcplsc & 1.138847 & 0.238069 & 4.78 & 0.000 & 0.672241 & 1.605453 \\
\hline \multirow{5}{*}{$\begin{array}{l}\text { rho (fração da variância } \\
\text { devido a u_i) }\end{array}$} & 0.9376945 & jxhmmlbk & -0.051483 & 0.001553 & -33.1 & $5 \quad 0.000$ & -0.054527 & -0.04844 \\
\hline & & jxhmblsc & 0.1049741 & 0.216858 & 0.48 & 0.628 & -0.320059 & 0.530008 \\
\hline & & jxcoblsc & 0.0981445 & 0.002859 & 34.33 & 0.000 & 0.0925414 & 0.103748 \\
\hline & & jxcomlsc & -0.001196 & 0.001997 & -0.60 & 0.549 & -0.00511 & 0.002717 \\
\hline & & cons & 4857.391 & 87.91065 & 55.25 & 0.000 & 4685.089 & 5029.692 \\
\hline
\end{tabular}

\begin{tabular}{|c|c|c|c|c|c|c|c|c|}
\hline \multicolumn{9}{|c|}{ 9. Crescimento PIB per capita (anual \%) } \\
\hline \multicolumn{2}{|l|}{ Parâmetros } & \multirow{2}{*}{$\begin{array}{l}\text { i_PIBperca / } \\
\text { j_PIBperca | }\end{array}$} & \multirow{2}{*}{$\begin{array}{l}\text { Coef. } \\
0.0694466\end{array}$} & \multirow{2}{*}{$\begin{array}{l}\text { Std. Err. } \\
0.003027\end{array}$} & \multirow{2}{*}{22.95} & \multirow{2}{*}{$\begin{array}{l}P>z \\
0.000\end{array}$} & \multicolumn{2}{|c|}{ [95\% Conf.Interval] } \\
\hline Tipo de regressão: & Random-effects GLS & & & & & & 0.0635146 & 0.075379 \\
\hline \multirow[t]{2}{*}{ Variável agrupadora: } & Pares de países (par) & mablbk & 0.1645733 & 0.156679 & 1.05 & 0.294 & -0.142511 & 0.471658 \\
\hline & & maplbk & 0.6209456 & 0.169135 & 3.67 & 0.000 & 0.2894476 & 0.952444 \\
\hline \multicolumn{2}{|l|}{$R$-quadrado: } & mamlbk & -0.469301 & 0.065019 & -7.22 & 0.000 & -0.596736 & -0.34186 \\
\hline - dentre & 0.0366 & mamlsc & 1.092993 & 0.064417 & 16.97 & 0.000 & 0.9667371 & 1.219249 \\
\hline - entre & 0.022 & rcblbk & -0.52049 & 5.108471 & -0.10 & 0.919 & -10.53291 & 9.491928 \\
\hline \multirow[t]{2}{*}{ - geral } & 0.0352 & rcplbk & -1.128452 & 0.194096 & -5.81 & 0.000 & -1.508874 & -0.74803 \\
\hline & & rcmlbk & 0.1533171 & 0.035404 & 4.33 & 0.000 & 0.0839275 & 0.222707 \\
\hline Efeitos alearórios $u \_i$ : & Gaussianos & rcblsc & -0.194391 & 4.993904 & -0.04 & 0.969 & -9.982264 & 9.593482 \\
\hline \multirow[t]{2}{*}{ corr $\left(u \_i\right)$ : } & 0 (assumido) & rcplsc & 0.947984 & 5.254681 & 0.18 & 0.857 & -9.351002 & 11.24697 \\
\hline & & hmmlbk & 0.5819397 & 0.026965 & 21.58 & 0.000 & 0.5290892 & 0.63479 \\
\hline Número de obs: & 247687 & hmblsc & -2.039901 & 5.137022 & -0.40 & 0.691 & -12.10828 & 8.028478 \\
\hline Número de grupos: & 8100 & coblsc & -0.683057 & 0.083966 & -8.13 & 0.000 & -0.847626 & -0.51849 \\
\hline \multicolumn{2}{|l|}{ Observações por grupos: } & comlsc & 0.1117288 & 0.077952 & 1.43 & 0.152 & -0.041054 & 0.264512 \\
\hline$-\min$ & 12 & jxmablbk & -0.127399 & 0.03898 & -3.27 & 0.001 & -0.203799 & -0.051 \\
\hline - mad & 30.6 & jxmaplbk & 0.1267747 & 0.043632 & 2.91 & 0.004 & 0.041258 & 0.212291 \\
\hline \multirow[t]{2}{*}{$-\max$} & 36 & jxmamlbk & -0.00291 & 0.014094 & -0.21 & 0.836 & -0.030534 & 0.024715 \\
\hline & & jxmamlsc & 0.029481 & 0.014069 & 2.10 & 0.036 & 0.0019068 & 0.057055 \\
\hline Wald chi2: & 9260.17 & jxrcblbk & 1.403702 & 3.644043 & 0.39 & 0.700 & -5.738492 & 8.545896 \\
\hline \multirow[t]{2}{*}{ Prob. > chi2: } & 0 & jxrcplbk & 0.1023338 & 0.052672 & 1.94 & 0.052 & -0.000901 & 0.205569 \\
\hline & & jxrcmlbk & -0.068778 & 0.006942 & -9.91 & 0.000 & -0.082384 & -0.05517 \\
\hline sigma_u & 1.1876335 & jxrcblsc & -1.127502 & 3.625785 & -0.31 & 0.756 & -8.23391 & 5.978906 \\
\hline sigma_e & 4.4629472 & jxhmmlbk & 0.0526695 & 0.004338 & 12.14 & 0.000 & 0.0441666 & 0.061173 \\
\hline \multirow{5}{*}{$\begin{array}{l}\text { rho (fração da variância } \\
\text { devido a u_i) }\end{array}$} & 0.06613132 & jxhmblsc & 1.613713 & 3.655239 & 0.44 & 0.659 & -5.550424 & 8.77785 \\
\hline & & jxcoblsc & 0.0991296 & 0.019121 & 5.18 & 0.000 & 0.0616539 & 0.136605 \\
\hline & & jxcoplsc & -1.186188 & 3.673843 & -0.32 & 0.747 & -8.386787 & 6.014411 \\
\hline & & jxcomlsc & 0.0155269 & 0.018325 & 0.85 & 0.397 & -0.02039 & 0.051444 \\
\hline & & cons & 1.36211 & 0.019966 & 68.22 & 0.000 & 1.322977 & 1.401243 \\
\hline
\end{tabular}




\begin{tabular}{|c|c|c|c|c|c|c|c|c|}
\hline \multicolumn{9}{|c|}{ 10.Indice capital/ativos bancários (\%) } \\
\hline \multicolumn{2}{|l|}{ Parâmetros } & \multirow{2}{*}{$\begin{array}{l}\text { i_bankcapino } \\
\text { j_bankcapi o }\end{array}$} & \multirow{2}{*}{$\begin{array}{c}\text { Coef. } \\
-0.096097\end{array}$} & & $z$ & $P>z$ & {$[95 \%$ Conf. } & Interval] \\
\hline Tipo de regressão: & Random-effects GLS & & & 0.011807 & -8.14 & 0.000 & -0.119237 & -0.07296 \\
\hline Variável agrupadora: & Pares de países (par) & mablbk & -0.330101 & 0.182869 & -1.81 & 0.071 & -0.688517 & 0.028315 \\
\hline & & maplbk & -4.36665 & 0.515652 & -8.47 & 0.000 & -5.377309 & -3.35599 \\
\hline R-quadrado: & & mamlbk & -0.497215 & 0.129035 & -3.85 & 0.000 & -0.750119 & -0.24431 \\
\hline - dentre & 0.0417 & mamlsc & -1.281115 & 0.137275 & -9.33 & 0.000 & -1.550169 & -1.01206 \\
\hline - entre & 0.1342 & rcplbk & 3.536427 & 0.553989 & 6.380 & 0.000 & 2.450629 & 4.622226 \\
\hline - geral & 0.1334 & rcmlbk & -2.569199 & 0.155623 & -16.51 & 0.000 & -2.874214 & -2.26418 \\
\hline & & rcblsc & 4.573497 & 4.077413 & 1.120 & 0.262 & -3.418085 & 12.56508 \\
\hline Efeitos alearórios u_i: & Gaussianos & coblsc & 0.2349342 & 0.199131 & 1.180 & 0.238 & -0.155355 & 0.625224 \\
\hline corr $\left(u \_i\right)$ : & 0 (assumido) & coplsc & -11.63658 & 4.105592 & -2.83 & 0.005 & -19.6834 & -3.58977 \\
\hline & & comlsc & 0.3264583 & 0.086587 & 3.770 & 0.000 & 0.1567513 & 0.496165 \\
\hline Número de obs: & 41827 & jxmaplbk & 0.4728576 & 0.060786 & $7.78 \quad 0$ & 0.000 & 0.3537199 & 0.591995 \\
\hline Número de grupos: & 6241 & jxmamlbk & 0.0161267 & 0.012353 & 1.310 & 0.192 & -0.008084 & 0.040338 \\
\hline Observações por grupos: & & jxmablsc & 0.0148588 & 0.026417 & 0.560 & 0.574 & -0.036918 & 0.066636 \\
\hline$-\min$ & 2 & jxmamlsc & -0.007532 & 0.013029 & -0.58 & 0.563 & -0.033068 & 0.018005 \\
\hline - mad & 6.7 & jxrcblbk & 1.538261 & 0.482631 & 3.190 & 0.001 & 0.5923225 & 2.4842 \\
\hline$-\max$ & 8 & jxrcmlbk & 0.0798317 & 0.012992 & 6.140 & 0.000 & 0.0543671 & 0.105296 \\
\hline & & jxrcblsc & -0.556206 & 0.480859 & -1.16 & 0.247 & -1.498672 & 0.38626 \\
\hline Wald chi2: & 2559.02 & jxhmplbk & -0.429245 & 0.068098 & -6.30 & 0.000 & -0.562714 & -0.29578 \\
\hline Prob. > chi2: & 0 & jxcoblsc & -0.023965 & 0.022707 & -1.06 & 0.291 & -0.068469 & 0.02054 \\
\hline & & jxcomlsc & -0.008893 & 0.010756 & -0.83 & 0.408 & -0.029973 & 0.012188 \\
\hline sigma_u & 2.8989225 & cons & 12.00955 & 0.147966 & 81.16 & 0.000 & 11.71954 & 12.29955 \\
\hline sigma_e & 1.360203 & & & & & & & \\
\hline rho (fração da variância & 0.81956608 & & & & & & & \\
\hline devido a $u \_i$ ) & & & & & & & & \\
\hline 11.Empr & $s / E m$ & tais & & & & & & \\
\hline Parâmetros & & j_banknonp r & Coef. & Std. Err. & $z$ & $P>z$ & {$[95 \%$ Conf. } & Interval] \\
\hline Tipo de regressão: & Random-effects GLS & j_banknonp r r & 0.3374458 & 0.010778 & 31.31 & 0.000 & 0.3163214 & 0.35857 \\
\hline Variável agrupadora: & Pares de países (par) & mablbk & -0.716004 & 0.232478 & -3.08 & 0.002 & -1.171652 & -0.26036 \\
\hline & & maplbk & -1.053188 & 0.661308 & -1.59 & 0.111 & -2.349327 & 0.242952 \\
\hline R-quadrado: & & mamlbk & -3.036248 & 0.196177 & -15.48 & 0.000 & -3.420747 & -2.65175 \\
\hline - dentre & 0.1462 & mamlsc & 0.2595649 & 0.20643 & 1.260 & 0.209 & -0.145029 & 0.664159 \\
\hline - entre & 0.0537 & rcblbk & -1.083828 & 5.329832 & -0.20 & 0.839 & -11.53011 & 9.362451 \\
\hline - geral & 0.069 & $\mathrm{rcmlbk}$ & 1.635638 & 0.225593 & 7.250 & 0.000 & 1.193484 & 2.077792 \\
\hline & & rcblsc & 0.428954 & 5.276478 & $0.08 \quad 0$ & 0.935 & -9.912753 & 10.77066 \\
\hline Efeitos alearórios u_i: & Gaussianos & hmplbk & 0.197584 & 0.700188 & 0.280 & 0.778 & -1.174759 & 1.569927 \\
\hline corr $\left(u \_i\right)$ : & 0 (assumido) & coblsc & -1.281357 & 0.257324 & -4.98 & 0.000 & -1.785703 & -0.77701 \\
\hline & & comlsc & -1.787481 & 0.115829 & -15.43 & 0.000 & -2.0145 & -1.56046 \\
\hline Número de obs: & 43998 & jxmablbk & -0.012338 & 0.063506 & -0.19 & 0.846 & -0.136807 & 0.112131 \\
\hline Número de grupos: & 6241 & jxmaplbk & -0.07736 & 0.151138 & -0.51 & 0.609 & -0.373584 & 0.218865 \\
\hline Observações por grupos: & & jxmamlbk & -0.077834 & 0.011817 & -6.59 & 0.000 & -0.100996 & -0.05467 \\
\hline$-\min$ & 1 & jxmamlsc & -0.056014 & 0.012364 & -4.53 & 0.000 & -0.080247 & -0.03178 \\
\hline- mad & 7 & jxrcblbk & 1.205932 & 2.897369 & 0.420 & 0.677 & -4.472808 & 6.884672 \\
\hline$-\max$ & 8 & jxrcplbk & 0.0875862 & 0.164702 & 0.530 & 0.595 & -0.235223 & 0.410396 \\
\hline & & jxrcmlbk & -0.029072 & 0.012107 & -2.40 & 0.016 & -0.052801 & -0.00534 \\
\hline Wald chi2: & 6279.7 & jxrcblsc & -0.390648 & 2.89605 & -0.13 & 0.893 & -6.066803 & 5.285506 \\
\hline Prob. > chi2: & 0 & jxcoblsc & 0.0148465 & 0.019061 & $0.78 \quad 0$ & 0.436 & -0.022513 & 0.052206 \\
\hline & & jxcomlsc & -0.002543 & 0.011766 & -0.22 & 0.829 & -0.025604 & 0.020518 \\
\hline sigma_u & 5.8393067 & cons & 6.436365 & 0.210708 & 30.55 & 0.000 & 6.023384 & 6.849345 \\
\hline sigma_e & 4.1367079 & & & & & & & \\
\hline rho (fração da variância & 0.66583868 & & & & & & & \\
\hline devido a $\left.u \_i\right)$ & & & & & & & & \\
\hline 12.T & 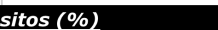 & & & & & & & \\
\hline Parâmetros & & i_depositine & Coef. & Std. Err. & $z$ & $P>z$ & {$[95 \%$ Conf. } & Interval] \\
\hline Tipo de regressão: & Random-effects GLS & j_depositi e & -0.002299 & 0.002584 & -0.89 & 0.374 & -0.007363 & 0.002766 \\
\hline Variável agrupadora: & Pares de países (par) & mablbk & -35.53151 & 136.2151 & -0.26 & 0.794 & -302.5083 & 231.4452 \\
\hline & & maplbk & -126.5148 & 149.5237 & -0.85 & 0.397 & -419.5759 & 166.5463 \\
\hline R-quadrado: & & mamlbk & 46.74424 & 34.37715 & 1.360 & 0.174 & -20.63374 & 114.1222 \\
\hline - dentre & 0.0193 & mamlsc & 97.2607 & 34.2743 & 2.840 & 0.005 & 30.0843 & 164.4371 \\
\hline - entre & 0.0008 & rcplbk & 228.5831 & 157.1375 & 1.450 & 0.146 & -79.40072 & 536.567 \\
\hline - geral & 0.0168 & remlbk & -120.5798 & 22.03679 & -5.47 & 0.000 & -163.7711 & -77.3885 \\
\hline & & rcblsc & 325.2126 & 984.9425 & 0.330 & 0.741 & -1605.239 & 2255.664 \\
\hline Efeitos alearórios u_i: & Gaussianos & replsc & -426.6717 & 989.8402 & -0.43 & 0.666 & -2366.723 & 1513.38 \\
\hline corr $\left(u \_i\right)$ : & 0 (assumido) & hmmlbk & -220.3511 & 18.70929 & -11.78 & 0.000 & -257.0206 & -183.682 \\
\hline & & coblsc & -26.36976 & 45.44612 & -0.58 & 0.562 & -115.4425 & 62.70301 \\
\hline Número de obs: & 150223 & comlsc & -4.675805 & 44.96314 & -0.10 & 0.917 & -92.80195 & 83.45034 \\
\hline Número de grupos: & 7332 & jxmablbk & -5.563473 & 24.22462 & -0.23 & 0.818 & -53.04285 & 41.9159 \\
\hline Observações por grupos: & & jxmaplbk & 1.798028 & 15.69425 & 0.110 & 0.909 & -28.96213 & 32.55819 \\
\hline$-\min$ & 1 & jxmamlbk & -0.234097 & 2.106874 & -0.11 & 0.912 & -4.363495 & 3.8953 \\
\hline - mad & 20.5 & jxmamlsc & -0.736417 & 2.074956 & -0.35 & 0.723 & -4.803255 & 3.330423 \\
\hline$-\max$ & 36 & jxrcblbk & -20.33146 & 116.4138 & -0.17 & 0.861 & -248.4983 & 207.8354 \\
\hline & & jxrcplbk & 2.981746 & 22.2276 & 0.130 & 0.893 & -40.58355 & 46.54704 \\
\hline Wald chi2: & 2879.29 & jxrcmlbk & 1.224582 & 0.927282 & 1.320 & 0.187 & -0.592858 & 3.042021 \\
\hline Prob. > chi2: & 0 & jxrcplsc & 20.72426 & 115.5071 & $0.18 \quad 0$ & 0.858 & -205.6654 & 247.1139 \\
\hline & & jxhmmlbk & 0.0001161 & 0.042479 & 0.000 & 0.998 & -0.083141 & 0.083373 \\
\hline sigma_u & 1256.4055 & jxcoblsc & -0.040949 & 0.162716 & -0.25 & 0.801 & -0.359867 & 0.277969 \\
\hline sigma_e & 2196.6331 & jxcomlsc & 1.179958 & 5.018577 & $0.24 \quad 0$ & 0.814 & -8.656271 & 11.01619 \\
\hline rho (fração da variância & 0.24650469 & cons & 262.8937 & 18.60474 & 14.13 & 0.000 & 226.4291 & 299.3583 \\
\hline devido a u_i) & & & & & & & & \\
\hline
\end{tabular}




\begin{tabular}{|c|c|c|c|c|c|c|c|}
\hline \multicolumn{8}{|c|}{ 13.Taxa de juros - Empréstimos (\%) } \\
\hline \multicolumn{2}{|l|}{ Parâmetros } & \multirow{2}{*}{$\begin{array}{l}\text { i_lendingine } \\
\text { j_lendingine }\end{array}$} & \multirow{2}{*}{$\begin{array}{l}\text { Coef. } \\
-0.002208\end{array}$} & \multirow{2}{*}{$\begin{array}{l}\text { Std. Err. } \\
0.002728\end{array}$} & \multirow{2}{*}{$\begin{array}{cl}\mathbf{z} & \mathbf{P}>\mathbf{z} \\
-0.81 & 0.418\end{array}$} & \multicolumn{2}{|c|}{ [95\% Conf.Interval] } \\
\hline Tipo de regressão: & Random-effects GLS & & & & & -0.007555 & 0.003138 \\
\hline \multirow{2}{*}{ Variável agrupadora: } & Pares de países (par) & mablbk & -35.48433 & 179.5515 & $-0.20 \quad 0.843$ & -387.3987 & 316.4301 \\
\hline & & maplbk & -195.9135 & 193.3061 & $-1.01 \quad 0.311$ & -574.7864 & 182.9594 \\
\hline \multicolumn{2}{|l|}{$R$-quadrado: } & mamlbk & 83.81893 & 40.37027 & $2.08 \quad 0.038$ & 4.694654 & 162.9432 \\
\hline - dentre & 0.0198 & mamlsc & 56.96801 & 40.33456 & $1.41 \quad 0.158$ & -22.08628 & 136.0223 \\
\hline - entre & 0.0017 & rcblbk & 270.5775 & 6930.029 & $0.04 \quad 0.969$ & -13312.03 & 13853.19 \\
\hline \multirow[t]{2}{*}{ - geral } & 0.0171 & remlbk & -84.513 & 27.71264 & $-3.05 \quad 0.002$ & -138.8288 & -30.1972 \\
\hline & & rcblsc & 39.7879 & 6747.206 & $0.01 \quad 0.995$ & -13184.49 & 13264.07 \\
\hline Efeitos alearórios $u \_i$ : & Gaussianos & rcplsc & -668.5996 & 7164.462 & $-0.09 \quad 0.926$ & -14710.69 & 13373.49 \\
\hline \multirow{2}{*}{$\operatorname{corr}\left(u_{-} i\right):$} & 0 (assumido) & hmplbk & 187.8126 & 216.9711 & $0.87 \quad 0.387$ & -237.443 & 613.0682 \\
\hline & & hmmlbk & -275.8856 & 25.6267 & $-10.77 \quad 0.000$ & -326.113 & -225.658 \\
\hline Número de obs: & 134400 & hmblsc & 214.0791 & 6982.433 & $0.03 \quad 0.976$ & -13471.24 & 13899.4 \\
\hline Número de grupos: & 7343 & coblsc & 88.58578 & 66.83464 & $1.33 \quad 0.185$ & -42.40771 & 219.5793 \\
\hline \multicolumn{2}{|l|}{ Observações por grupos: } & comlsc & 25.72236 & 55.89468 & $0.46 \quad 0.645$ & -83.82921 & 135.2739 \\
\hline$-\min$ & 1 & jxmablbk & 1.905669 & 19.18662 & $0.10 \quad 0.921$ & -35.69941 & 39.51075 \\
\hline - mad & 18.3 & jxmaplbk & 4.242315 & 12.29977 & $0.34 \quad 0.730$ & -19.86479 & 28.34942 \\
\hline \multirow{2}{*}{$-\max$} & 36 & jxmamlbk & -0.155932 & 0.971393 & $-0.16 \quad 0.872$ & -2.059827 & 1.747963 \\
\hline & & jxmamlsc & -0.127607 & 0.976466 & $-0.13 \quad 0.896$ & -2.041445 & 1.78623 \\
\hline Wald chi2: & 2630.88 & jxrcblbk & -18.85188 & 939.6967 & $-0.02 \quad 0.984$ & -1860.624 & 1822.92 \\
\hline \multirow[t]{2}{*}{ Prob. > chi2: } & 0 & jxrcplbk & 5.792823 & 18.80418 & $0.31 \quad 0.758$ & -31.06269 & 42.64834 \\
\hline & & jxrcmlbk & 0.1911845 & 0.63592 & $0.30 \quad 0.764$ & -1.055196 & 1.437565 \\
\hline sigma_u & 1607.9733 & jxrcblsc & -1.063506 & 930.0098 & $-0.00 \quad 0.999$ & -1823.849 & 1821.722 \\
\hline sigma_e & 2512.7809 & jxrcplsc & 3.561837 & 975.0921 & $0.00 \quad 0.997$ & -1907.584 & 1914.707 \\
\hline \multirow{5}{*}{$\begin{array}{l}\text { rho (fração da variância } \\
\text { devido } a \text { u_i) }\end{array}$} & 0.29052596 & jxhmmlbk & 0.1265835 & 0.462166 & $0.27 \quad 0.784$ & -0.779245 & 1.032412 \\
\hline & & jxhmblsc & 6.637234 & 965.4557 & $0.01 \quad 0.995$ & -1885.621 & 1898.896 \\
\hline & & jxcoblsc & -0.072682 & 3.379134 & $-0.02 \quad 0.983$ & -6.695663 & 6.5503 \\
\hline & & jxcomlsc & -1.183829 & 4.108071 & $-0.29 \quad 0.773$ & -9.235499 & 6.867842 \\
\hline & & cons & 293.0438 & 23.85767 & $12.28 \quad 0.000$ & 246.2836 & 339.8039 \\
\hline \multicolumn{8}{|c|}{ 14.Taxa de juros - spread (taxa empréstimo menos taxa depósito } \\
\hline \multicolumn{2}{|l|}{ Parâmetros } & i_interest $m$ & Coef. & Std. Err. & $z \quad P>z$ & {$[95 \%$ Conf } & Interval] \\
\hline Tipo de regressão: & Random-effects GLS & j_interest m & -0.003213 & 0.002911 & $-1.10 \quad 0.270$ & -0.008918 & 0.002492 \\
\hline Variável agrupadora: & Pares de países (par) & mablbk & -3.089914 & 25.10418 & $-0.12 \quad 0.902$ & -52.2932 & 46.11338 \\
\hline & & maplbk & -19.0797 & 19.58265 & $-0.97 \quad 0.330$ & -57.461 & 19.30159 \\
\hline$R$-quadrado: & & mamlbk & 32.84552 & 5.195978 & $6.32 \quad 0.000$ & 22.66159 & 43.02945 \\
\hline - dentre & 0.0218 & mamlsc & -16.84806 & 5.139654 & $\begin{array}{ll}-3.28 & 0.001\end{array}$ & -26.9216 & -6.77453 \\
\hline - entre & 0.0013 & rcblbk & 18.58315 & 329.5018 & $0.06 \quad 0.955$ & -627.2286 & 664.3949 \\
\hline - geral & 0.018 & rcplbk & 18.29524 & 28.83393 & $0.63 \quad 0.526$ & -38.21822 & 74.8087 \\
\hline & & rcmlbk & -7.153204 & 3.512984 & $-2.04 \quad 0.042$ & -14.03853 & -0.26788 \\
\hline Efeitos alearórios $u \_i$ : & Gaussianos & rcplsc & -44.52299 & 330.5693 & $-0.13 \quad 0.893$ & -692.4268 & 603.3808 \\
\hline $\operatorname{corr}\left(u_{-} i\right)$ : & 0 (assumido) & hmmlbk & -39.7604 & 3.381303 & $-11.76 \quad 0.000$ & -46.38763 & -33.1332 \\
\hline & & coblsc & 10.88737 & 9.392502 & $1.16 \quad 0.246$ & -7.521597 & 29.29634 \\
\hline Número de obs: & 118244 & comlsc & 1.121157 & 7.231697 & $0.16 \quad 0.877$ & -13.05271 & 15.29502 \\
\hline Número de grupos: & 6977 & jxmablbk & 0.3929448 & 5.271228 & $0.07 \quad 0.941$ & -9.938472 & 10.72436 \\
\hline Observações por grupos: & & jxmaplbk & 0.3258166 & 2.474911 & $0.13 \quad 0.895$ & -4.524921 & 5.176554 \\
\hline$-\min$ & 1 & jxmamlbk & -0.063663 & 0.177076 & $-0.36 \quad 0.719$ & -0.410726 & 0.2834 \\
\hline - mad & 16.9 & jxmamlsc & 0.0449087 & 0.175723 & $0.26 \quad 0.798$ & -0.299503 & 0.38932 \\
\hline$-\max$ & 36 & jxrcblbk & -1.808246 & 77.68818 & $-0.02 \quad 0.981$ & -154.0743 & 150.4578 \\
\hline & & jxrcmlbk & -0.005419 & 0.126956 & $-0.04 \quad 0.966$ & -0.254248 & 0.24341 \\
\hline Wald chi2: & 2541.62 & jxhmplbk & 2.741755 & 5.548351 & $0.49 \quad 0.621$ & -8.132814 & 13.61632 \\
\hline Prob. > chi2: & 0 & jxhmmlbk & 0.0129909 & 0.102273 & $0.13 \quad 0.899$ & -0.18746 & 0.213442 \\
\hline & & jxcoblsc & -0.271673 & 0.897648 & $-0.30 \quad 0.762$ & -2.031031 & 1.487685 \\
\hline sigma_u & 244.40034 & jxcoplsc & -0.130089 & 77.67527 & $-0.00 \quad 0.999$ & -152.3708 & 152.1106 \\
\hline sigma_e & 313.57242 & jxcomlsc & -0.236114 & 0.834913 & $-0.28 \quad 0.777$ & -1.872513 & 1.400285 \\
\hline rho (fração da variância & 0.37790607 & cons & 48.72184 & 3.574978 & $13.63 \quad 0.000$ & 41.71501 & 55.72866 \\
\hline devido a $\left.u \_i\right)$ & & & & & & & \\
\hline
\end{tabular}

\begin{tabular}{|c|c|c|c|c|c|c|c|c|}
\hline \multicolumn{9}{|l|}{ 15.Juros reais (\%) } \\
\hline \multicolumn{2}{|l|}{ Parâmetros } & \multirow{2}{*}{\begin{tabular}{|l} 
i_realintene \\
j_realinte $\sim$ e
\end{tabular}} & \multirow{2}{*}{$\frac{\text { Coef. }}{-0.001644}$} & \multirow{2}{*}{$\frac{\text { Std. Err. }}{0.003125}$} & \multirow{2}{*}{$\frac{z}{-0.53}$} & \multirow{2}{*}{$\frac{P>z}{0.599}$} & \multicolumn{2}{|c|}{ [95\% Conf.Interval] } \\
\hline Tipo de regressão: & Random-effects GLS & & & & & & -0.007769 & 0.004481 \\
\hline \multirow[t]{2}{*}{ Variável agrupadora: } & Pares de países (par) & maplbk & 0.8598944 & 1.025196 & 0.84 & 0.402 & -1.149453 & 2.869242 \\
\hline & & mamlbk & -0.784301 & 0.361993 & -2.17 & 0.030 & -1.493795 & -0.07481 \\
\hline \multicolumn{2}{|l|}{$R$-quadrado: } & mablsc & -2.001614 & 0.879864 & -2.27 & 0.023 & -3.726117 & -0.27711 \\
\hline - dentre & 0.0205 & mamlsc & -1.617895 & 0.359169 & -4.50 & 0.000 & -2.321854 & -0.91394 \\
\hline - entre & 0.0168 & rcblbk & -0.80922 & 73.36159 & -0.01 & 0.991 & -144.5953 & 142.9769 \\
\hline \multirow[t]{2}{*}{ - geral } & 0.0235 & rcplbk & -1.092534 & 1.258017 & -0.87 & 0.385 & -3.558202 & 1.373134 \\
\hline & & rcmlbk & 0.8446756 & 0.221092 & 3.82 & 0.000 & 0.4113434 & 1.278008 \\
\hline Efeitos alearórios u_i: & Gaussianos & rcblsc & 2.611076 & 72.31936 & 0.04 & 0.971 & -139.1323 & 144.3544 \\
\hline \multirow[t]{2}{*}{$\operatorname{corr}\left(u \_i\right)$ : } & 0 (assumido) & rcplsc & -0.624844 & 73.85908 & -0.01 & 0.993 & -145.386 & 144.1363 \\
\hline & & hmmlbk & 2.374562 & 0.200129 & 11.87 & 0.000 & 1.982317 & 2.766808 \\
\hline Número de obs: & 130494 & hmblsc & -3.746594 & 72.80045 & -0.05 & 0.959 & -146.4329 & 138.9397 \\
\hline Número de grupos: & 7335 & coblsc & -0.308789 & 0.499419 & -0.62 & 0.536 & -1.287633 & 0.670055 \\
\hline \multicolumn{2}{|l|}{ Observações por grupos: } & comlsc & -0.584503 & 0.378959 & -1.54 & 0.123 & -1.327249 & 0.158243 \\
\hline$-\min$ & 1 & jxmablbk & -0.059018 & 0.169507 & -0.35 & 0.728 & -0.391246 & 0.273211 \\
\hline - mad & 17.8 & jxmaplbk & -0.020994 & 0.113926 & -0.18 & 0.854 & -0.244285 & 0.202298 \\
\hline \multirow{2}{*}{ - max } & 36 & jxmamlbk & 0.0054941 & 0.028029 & 0.20 & 0.845 & -0.049441 & 0.060429 \\
\hline & & jxmamlsc & 0.0058199 & 0.027343 & 0.21 & 0.831 & -0.04777 & 0.05941 \\
\hline Wald chi2: & 2771.82 & jxrcblbk & 1.035205 & 19.82833 & 0.05 & 0.958 & -37.82761 & 39.89802 \\
\hline \multirow[t]{2}{*}{ Prob. > chi2: } & 0 & jxrcplbk & -0.093218 & 0.191666 & -0.49 & 0.627 & -0.468877 & 0.282442 \\
\hline & & jxrcmlbk & 0.016275 & 0.012741 & 1.28 & 0.201 & -0.008697 & 0.041247 \\
\hline sigma_u & 12.321762 & jxrcblsc & -0.4812 & 19.77162 & -0.02 & 0.981 & -39.23287 & 38.27047 \\
\hline sigma_e & 20.286571 & jxrcplsc & -0.180674 & 19.89097 & -0.01 & 0.993 & -39.16625 & 38.8049 \\
\hline \multirow{5}{*}{$\begin{array}{l}\text { rho (fração da variância } \\
\text { devido a u_i) }\end{array}$} & 0.26949537 & jxhmmlbk & 0.0200153 & 0.008185 & 2.45 & 0.014 & 0.0039733 & 0.036057 \\
\hline & & jxhmblsc & 0.691161 & 19.83298 & 0.03 & 0.972 & -38.18077 & 39.56309 \\
\hline & & jxcoblsc & 0.0935557 & 0.036013 & 2.60 & 0.009 & 0.0229709 & 0.164141 \\
\hline & & jxcomlsc & -0.03078 & 0.04072 & -0.76 & 0.450 & -0.110589 & 0.04903 \\
\hline & & cons & 4.880087 & 0.190945 & 25.56 & 0.000 & 4.505842 & 5.254331 \\
\hline
\end{tabular}




\begin{tabular}{|c|c|c|c|c|c|c|c|c|}
\hline \multicolumn{2}{|l|}{ Parâmetros } & \multirow{2}{*}{\begin{tabular}{|l} 
i_riskprem $\sim m$ \\
j_riskprem m
\end{tabular}} & & Std, Err. & $z$ & $P>z$ & {$[95 \%$ Conf. } & Interval] \\
\hline Tipo de regressão: & Random-effects GLS & & -0.00445 & 0.006381 & -0.70 & 0.486 & -0.016957 & 0.008056 \\
\hline Variável agrupadora: & Pares de países (par) & mablbk & -0.335159 & 2.586396 & -0.13 & 0.897 & -5.404403 & 4.734084 \\
\hline & & maplbk & -3.28296 & 1.233309 & -2.66 & 0.008 & -5.700201 & -0.86572 \\
\hline R-quadrado: & & mamlbk & 16.85829 & 0.643306 & 26.21 & 0.000 & 15.59743 & 18.11914 \\
\hline - dentre & 0.0538 & mamlsc & -18.97796 & 0.656282 & -28.92 & $2 \quad 0.000$ & -20.26425 & -17.6917 \\
\hline - entre & 0.0463 & rcblbk & -5.476755 & 24.83241 & -0.22 & 0.825 & -54.14738 & 43.19387 \\
\hline - geral & 0.0491 & rcplbk & 1.7192 & 1.695621 & 1.01 & 0.311 & -1.604157 & 5.042557 \\
\hline & & rcmlbk & 2.882009 & 0.38967 & 7.40 & 0.000 & 2.11827 & 3.645748 \\
\hline Efeitos alearórios $u_{-} i$ : & Gaussianos & rcblsc & 2.440999 & 14.83644 & 0.16 & 0.869 & -26.63788 & 31.51988 \\
\hline $\operatorname{corr}\left(u_{-} i\right)$ : & 0 (assumido) & rcplsc & -1.673822 & 20.17172 & -0.08 & 0.934 & -41.20967 & 37.86203 \\
\hline & & hmmlbk & -1.702608 & 0.393708 & -4.32 & 0.000 & -2.474261 & -0.93096 \\
\hline Número de obs: & 42336 & coblsc & 0.312174 & 0.746387 & 0.42 & 0.676 & -1.150718 & 1.775066 \\
\hline Número de grupos: & 3067 & comlsc & -1.414934 & 0.560083 & -2.53 & 0.012 & -2.512676 & -0.31719 \\
\hline Observações por grupos: & & jxmablbk & 0.2521356 & 0.748328 & 0.34 & 0.736 & -1.21456 & 1.718831 \\
\hline$-\min$ & 1 & jxmaplbk & -0.121376 & 0.273518 & -0.44 & 0.657 & -0.657461 & 0.414709 \\
\hline - mad & 13.8 & jxmamlbk & -0.057816 & 0.023921 & -2.42 & 0.016 & -0.1047 & -0.01093 \\
\hline$-\max$ & 36 & jxmamlsc & 0.0545885 & 0.023991 & 2.28 & 0.023 & 0.0075664 & 0.101611 \\
\hline & & jxrcblbk & 0.8552074 & 5.637397 & 0.15 & 0.879 & -10.19389 & 11.9043 \\
\hline Wald chi2: & 2329.14 & jxrcplbk & -0.083029 & 0.417168 & -0.20 & 0.842 & -0.900662 & 0.734605 \\
\hline Prob. > chi2: & 0 & jxrcmlbk & -0.028403 & 0.016783 & -1.69 & 0.091 & -0.061296 & 0.00449 \\
\hline & & jxrcblsc & -0.358032 & 8.403075 & -0.04 & 0.966 & -16.82776 & 16.11169 \\
\hline sigma_u & 10.448204 & jxhmmlbk & 0.0188501 & 0.016043 & 1.17 & 0.240 & -0.012594 & 0.050294 \\
\hline sigma_e & 21.77715 & jxhmblsc & 0.4925968 & 6.197402 & 0.08 & 0.937 & -11.65409 & 12.63928 \\
\hline rho (fração da variância & 0.1871156 & jxcoblsc & -0.038153 & 0.069923 & -0.55 & 0.585 & -0.175199 & 0.098893 \\
\hline devido a u_i) & & jxcomlsc & 0.01788 & 0.062435 & 0.29 & 0.775 & -0.104491 & 0.140251 \\
\hline & & cons & 8.651528 & 0.333765 & 25.92 & 0.000 & 7.997361 & 9.305695 \\
\hline & & & & & & & & \\
\hline Parâmetros & & i_domesticnn & Coef. & Std. Err. & $z$ & $P>z$ & {$[95 \%$ Conf. } & Interval] \\
\hline Tipo de regressão: & Random-effects GLS & j_domestic n & 0.1375836 & 0.002944 & 46.73 & 0.000 & 0.1318134 & 0.143354 \\
\hline Variável agrupadora: & Pares de países (par) & mablbk & 16.0795 & 1.337277 & 12.02 & 0.000 & 13.45848 & 18.70051 \\
\hline & & maplbk & 4.633272 & 1.542371 & 3.00 & 0.003 & 1.61028 & 7.656263 \\
\hline R-quadrado: & & mamlbk & 13.08305 & 0.444857 & 29.41 & 0.000 & 12.21115 & 13.95495 \\
\hline - dentre & 0.1968 & mamlsc & 9.125064 & 0.444277 & 20.54 & 0.000 & 8.254298 & 9.99583 \\
\hline - entre & 0.0445 & rcblbk & 40.27765 & 87.05621 & 0.46 & 0.644 & -130.3494 & 210.9047 \\
\hline - geral & 0.0886 & rcplbk & 0.4782879 & 1.961139 & 0.24 & 0.807 & -3.365474 & 4.32205 \\
\hline & & rcmlbk & -2.785901 & 0.293125 & -9.50 & 0.000 & -3.360416 & -2.21139 \\
\hline Efeitos alearórios u_i: & Gaussianos & rcblsc & -39.71866 & 85.45526 & -0.46 & 0.642 & -207.2079 & 127.7706 \\
\hline corr $\left(u \_i\right)$ : & 0 (assumido) & hmmlbk & 15.43561 & 0.265651 & 58.10 & 0.000 & 14.91494 & 15.95627 \\
\hline & & hmblsc & 2.837895 & 87.23507 & 0.03 & 0.974 & -168.1397 & 173.8155 \\
\hline Número de obs: & 220597 & hmplsc & -107.9856 & 88.92272 & -1.21 & 0.225 & -282.271 & 66.29969 \\
\hline Número de grupos: & 7921 & coblsc & -0.497226 & 0.728847 & -0.68 & 0.495 & -1.92574 & 0.931287 \\
\hline Observações por grupos: & & comlsc & 3.733917 & 0.527828 & 7.07 & 0.000 & 2.699394 & 4.768441 \\
\hline$-\min$ & 9 & jxmablbk & -0.035561 & 0.011343 & -3.14 & 0.002 & -0.057792 & -0.01333 \\
\hline - mad & 27.8 & jxmaplbk & -0.131564 & 0.016365 & -8.04 & 0.000 & -0.163638 & -0.09949 \\
\hline$-\max$ & 36 & jxmamlbk & 0.0010216 & 0.004568 & 0.22 & 0.823 & -0.007931 & 0.009975 \\
\hline & & jxmamlsc & -0.009068 & 0.004578 & -1.98 & 0.048 & -0.018041 & $-9.5 \mathrm{E}-05$ \\
\hline Wald chi2: & 52096.34 & jxrcblbk & -0.148826 & 0.481041 & -0.31 & 0.757 & -1.09165 & 0.793998 \\
\hline Prob. > chiz: & 0 & jxrcplbk & 0.1434986 & 0.019603 & 7.32 & 0.000 & 0.1050771 & 0.18192 \\
\hline & & jxrcmlbk & -0.004231 & 0.003329 & -1.27 & 0.204 & -0.010757 & 0.002295 \\
\hline sigma_u & 10.448204 & jxrcblsc & 0.3765042 & 0.45402 & 0.83 & 0.407 & -0.513359 & 1.266368 \\
\hline sigma_e & 21.77715 & jxrcplsc & 0.5851951 & 0.491255 & 1.19 & 0.234 & -0.377647 & 1.548037 \\
\hline rho (fração da variância & 0.1871156 & jxhmmlbk & -0.095245 & 0.00336 & -28.35 & $5 \quad 0.000$ & -0.10183 & -0.08866 \\
\hline devido a u_i) & & jxhmblsc & 0.1208432 & 0.464285 & 0.26 & 0.795 & -0.789139 & 1.030826 \\
\hline & & jxcoblsc & 0.0571145 & 0.006346 & 9.00 & 0.000 & 6767 & 0.069552 \\
\hline & & jxcomlsc & 0.0027346 & 0.004516 & 0.61 & 0.545 & -0.006116 & 0.011585 \\
\hline & & cons & 45.30319 & 0.471849 & 96.01 & 0.000 & 44.37839 & 46.228 \\
\hline Inn & $=0$ & & & & & & & \\
\hline Parâmetros & & i_foreignd N & Coef. & Std, Err. & $z$ & $P>Z$ & {$[95 \%$ Conf. } & Interval] \\
\hline Tipo de regressão: & Random-effects GLS & j_foreignd 1 & 0.0346867 & 0.009583 & 3.62 & 0.000 & 0.0159037 & 0.05347 \\
\hline Variável agrupadora: & Pares de países (par) & mablbk & 1.276302 & 0.132094 & 9.66 & 0.000 & 1.017402 & 1.535203 \\
\hline & & maplbk & -0.341979 & 0.131421 & -2.60 & 0.009 & -0.599559 & -0.0844 \\
\hline R-quadrado: & & mamlbk & 1.782695 & 0.05034 & 35.41 & 0.000 & 1.68403 & 1.88136 \\
\hline - dentre & 0.1273 & mamlsc & 0.4426767 & 0.050102 & 8.84 & 0.000 & 0.3444777 & 0.540876 \\
\hline - entre & 0.2085 & rcblbk & -2.753247 & 1.100571 & -2.50 & 0.012 & -4.910327 & -0.59617 \\
\hline - geral & 0.1337 & rcplbk & 0.6315802 & 0.131176 & 4.81 & 0.000 & 0.3744801 & 0.88868 \\
\hline & & rcmlbk & 0.587902 & 0.030589 & 19.22 & 0.000 & 0.5279489 & 0.647855 \\
\hline Efeitos alearórios u_i: & Gaussian & hmmlbk & 1.181887 & 0.026357 & 44.84 & 0.000 & 1.130228 & 1.233545 \\
\hline corr $\left(u \_i\right)$ : & 0 (assumido) & hmblsc & -2.364772 & 1.008434 & -2.34 & 0.019 & -4.341265 & -0.38828 \\
\hline & & hmplsc & -0.752586 & 1.513488 & -0.50 & 0.619 & -3.718968 & 2.213796 \\
\hline Número de obs: & 212626 & coblsc & -0.004228 & 0.070464 & -0.06 & 0.952 & -0.142335 & 0.13388 \\
\hline Número de grupos: & 8100 & comlsc & -1.008614 & 0.055503 & -18.17 & 70.000 & -1.117399 & -0.89983 \\
\hline Observações por grupos: & & jxmablbk & -0.141771 & 0.015874 & -8.93 & 0.000 & -0.172884 & -0.11066 \\
\hline$-\min$ & 8 & jxmaplbk & 0.262715 & 0.029856 & 8.80 & 0.000 & 0.204198 & 0.321232 \\
\hline - mad & 26.3 & jxmamlbk & 0.0011127 & 0.006648 & 0.17 & 0.867 & -0.011917 & 0.014143 \\
\hline$-\max$ & 35 & jxmamlsc & 0.0025697 & 0.006677 & 0.38 & 0.700 & -0.010516 & 0.015656 \\
\hline & & jxrcblbk & 0.3851593 & 0.391199 & 0.98 & 0.325 & -0.381576 & 1.151895 \\
\hline Wald chi2: & 31405.47 & jxrcplbk & -0.169508 & 0.029803 & -5.69 & 0.000 & -0.22792 & -0.1111 \\
\hline Prob. > chi2: & 0 & jxrcmlbk & -0.002251 & 0.004953 & -0.45 & 0.649 & -0.011959 & 0.007456 \\
\hline & & jxrcblsc & -0.007547 & 0.294368 & -0.03 & 0.980 & -0.584496 & 0.569403 \\
\hline sigma_u & 2.3391542 & jxrcplsc & 0.6469908 & 0.258628 & 2.50 & 0.012 & 0.140089 & 1.153893 \\
\hline sigma_e & 3.3691562 & jxhmmlbk & -0.009609 & 0.010112 & -0.95 & 0.342 & -0.029428 & 0.01021 \\
\hline rho (fração da variância & 0.3252505 & jxcoblsc & -0.043884 & 0.010556 & -4.16 & 0.000 & -0.064573 & -0.02319 \\
\hline devido a $u \_i$ ) & & jxcomlsc & 0.041335 & 0.008103 & 5.10 & 0.000 & 0.0254535 & 0.057217 \\
\hline & & cons & 1.322383 & 0.030804 & 42.93 & 0.000 & 1.262008 & 1.382758 \\
\hline
\end{tabular}




\begin{tabular}{|c|c|c|c|c|c|c|c|c|}
\hline \multicolumn{2}{|l|}{ Parâmetros } & \multirow{2}{*}{$\begin{array}{l}\text { i_foreignd wf } \\
\text { j_foreignd } \sim f\end{array}$} & \multirow{2}{*}{$\begin{array}{l}\text { Coef. } \\
0.1397083\end{array}$} & \multirow{2}{*}{$\begin{array}{l}\text { Std. Err. } \\
0.023717\end{array}$} & \multirow{2}{*}{\multicolumn{2}{|c|}{$\begin{array}{rc}\mathbf{z} & \mathbf{P}>\mathbf{z} \\
5.89 & 0.000\end{array}$}} & \multicolumn{2}{|c|}{ [95\% Conf.Interval] } \\
\hline Tipo de regressão: & Random-effects GLS & & & & & & 0.0932246 & 0.186192 \\
\hline \multirow[t]{2}{*}{ Variável agrupadora: } & Pares de países (par) & mablbk & 1.396462 & 0.118109 & 11.82 & 0.000 & 1.164973 & 1.627951 \\
\hline & & maplbk & -0.422705 & 0.140995 & -3.00 & 0.003 & -0.699051 & -0.14636 \\
\hline \multicolumn{2}{|l|}{ R-quadrado: } & mamlbk & 1.704207 & 0.063837 & 26.70 & 0.000 & 1.579089 & 1.829325 \\
\hline - dentre & 0.1118 & mamlsc & 0.9054913 & 0.063262 & 14.31 & 0.000 & 0.7814998 & 1.029483 \\
\hline - entre & 0.126 & rcblbk & -4.606497 & 9.744103 & -0.47 & 0.636 & -23.70459 & 14.49159 \\
\hline \multirow[t]{2}{*}{ - geral } & 0.1239 & rcplbk & 1.696867 & 0.143132 & 11.86 & 0.000 & 1.416334 & 1.9774 \\
\hline & & rcmlbk & 0.3751847 & 0.038491 & 9.75 & 0.000 & 0.2997437 & 0.450626 \\
\hline Efeitos alearórios u_i: & Gaussianos & rcblsc & 2.166447 & 9.709005 & 0.22 & 0.823 & -16.86285 & 21.19575 \\
\hline \multirow[t]{2}{*}{$\operatorname{corr}\left(u_{-} i\right)$ : } & 0 (assumido) & replsc & -0.161788 & 9.825489 & -0.02 & 0.987 & -19.41939 & 19.09582 \\
\hline & & hmmlbk & 0.4589061 & 0.038037 & 12.06 & 0.000 & 0.3843544 & 0.533458 \\
\hline Número de obs: & 117964 & hmblsc & -2.766566 & 9.785431 & -0.28 & 0.777 & -21.94566 & 16.41253 \\
\hline Número de grupos: & 7729 & coblsc & 0.0382027 & 0.074547 & 0.51 & 0.608 & -0.107906 & 0.184312 \\
\hline \multicolumn{2}{|l|}{ Observações por grupos: } & comlsc & -1.06351 & 0.053773 & 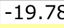 & $8 \quad 0.000$ & -1.168903 & -0.95812 \\
\hline$-\min$ & 1 & jxmablbk & -0.135695 & 0.014423 & -9.41 & 0.000 & -0.163964 & -0.10743 \\
\hline - mad & 15.3 & jxmaplbk & 0.0588574 & 0.035391 & 1.66 & 0.096 & -0.010508 & 0.128223 \\
\hline \multirow[t]{2}{*}{$-\max$} & 36 & jxmamlbk & -0.005571 & 0.008543 & -0.65 & 0.514 & -0.022314 & 0.011173 \\
\hline & & jxmamlsc & 0.0007331 & 0.008562 & 0.09 & 0.932 & -0.016049 & 0.017515 \\
\hline Wald chi2: & 15013.42 & jxrcblbk & 1.021459 & 3.140041 & 0.33 & 0.745 & -5.132907 & 7.175826 \\
\hline \multirow[t]{2}{*}{ Prob. > chi2: } & 0 & jxrcplbk & 0.0679365 & 0.035041 & 1.94 & 0.053 & -0.000742 & 0.136615 \\
\hline & & jxrcmlbk & 0.0214916 & 0.007956 & 2.70 & 0.007 & 0.0058985 & 0.037085 \\
\hline sigma_u & 2.5265668 & jxrcblsc & -0.894167 & 3.127701 & -0.29 & 0.775 & -7.024348 & 5.236014 \\
\hline sigma_e & 3.3545668 & jxrcplsc & 0.0636743 & 3.165739 & 0.02 & 0.984 & -6.141061 & 6.26841 \\
\hline \multirow{5}{*}{$\begin{array}{l}\text { rho (fração da variância } \\
\text { devido a u_i) }\end{array}$} & 0.36194724 & jxhmmlbk & -0.162281 & 0.024408 & -6.65 & 0.000 & -0.210121 & -0.11444 \\
\hline & & jxhmblsc & 0.7695317 & 3.153374 & 0.24 & 0.807 & -5.410969 & 6.950032 \\
\hline & & jxcoblsc & 0.0285436 & 0.010157 & 2.81 & 0.005 & 0.008636 & 0.048451 \\
\hline & & jxcomlsc & 0.0257778 & 0.008128 & 3.17 & 0.002 & 0.0098476 & 0.041708 \\
\hline & & & 1 & 0.039452 & 68 & 00 & 019735 & 35 \\
\hline
\end{tabular}

\begin{tabular}{|c|c|c|c|c|c|c|c|c|}
\hline \multicolumn{2}{|l|}{ Parâmetros } & i_portfolinu & \multirow{2}{*}{$\begin{array}{l}\text { Coef. } \\
0.021173\end{array}$} & \multirow{2}{*}{$\begin{array}{l}\text { Std. Err. } \\
0.014058\end{array}$} & \multirow{2}{*}{$\begin{array}{r}z \\
1.51\end{array}$} & \multirow{2}{*}{$\begin{array}{l}P>z \\
0.132\end{array}$} & \multicolumn{2}{|c|}{ [95\% Conf.Interval] } \\
\hline Tipo de regressão: & Random-effects GLS & j_portfoli u & & & & & -0.006379 & 0.048726 \\
\hline \multirow[t]{2}{*}{ Variável agrupadora: } & Pares de países (par) & mablbk & $5.30 \mathrm{E}+08$ & $3.30 E+08$ & 1.60 & 0.109 & $-1.18 \mathrm{E}+08$ & $1.18 \mathrm{E}+09$ \\
\hline & & maplbk & $-1.92 E+09$ & $3.93 E+08$ & -4.88 & 0.000 & $-2.69 E+09$ & $-1.15 E+09$ \\
\hline \multicolumn{2}{|l|}{ R-quadrado: } & mamlbk & $3.87 E+09$ & $1.31 \mathrm{E}+08$ & 29.52 & 0.000 & $3.61 E+09$ & $4.13 E+09$ \\
\hline - dentre & 0.0721 & mamlsc & $3.38 \mathrm{E}+09$ & $1.31 \mathrm{E}+08$ & 25.79 & 0.000 & $3.12 E+09$ & $3.63 E+09$ \\
\hline - entre & 0.1057 & rcplbk & $3.40 \mathrm{E}+09$ & $4.05 E+08$ & 8.39 & 0.000 & $2.61 \mathrm{E}+09$ & $4.20 \mathrm{E}+09$ \\
\hline \multirow[t]{2}{*}{ - geral } & 0.0779 & rcmlbk & $8.79 E+08$ & $7.91 E+07$ & 11.11 & 0.000 & $7.24 \mathrm{E}+08$ & $1.03 E+09$ \\
\hline & & rcblsc & $-6.37 E+09$ & $2.83 E+09$ & -2.25 & 0.025 & $-1.19 E+10$ & $-8.19 E+08$ \\
\hline Efeitos alearórios u_i: & Gaussianos & replsc & $-5.24 \mathrm{E}+10$ & $2.84 \mathrm{E}+09$ & -18.4 & $3 \quad 0.000$ & $-5.80 E+10$ & $-4.68 \mathrm{E}+10$ \\
\hline \multirow[t]{2}{*}{$\operatorname{corr}\left(u \_i\right)$ : } & 0 (assumido) & hmmlbk & $1.13 \mathrm{E}+09$ & $6.09 E+07$ & 18.59 & 0.000 & $1.01 \mathrm{E}+09$ & $1.25 \mathrm{E}+09$ \\
\hline & & hmblsc & $4.59 \mathrm{E}+10$ & $3.94 \mathrm{E}+09$ & 11.65 & 0.000 & $3.82 \mathrm{E}+10$ & $5.37 E+10$ \\
\hline Número de obs: & 254093 & coblsc & $3.43 E+09$ & $1.87 E+08$ & 18.38 & 0.000 & $3.07 E+09$ & $3.80 E+09$ \\
\hline Número de grupos: & 8100 & comlsc & $-2.08 \mathrm{E}+09$ & $1.42 \mathrm{E}+08$ & -14.7 & 20.000 & $-2.36 \mathrm{E}+09$ & $-1.81 \mathrm{E}+09$ \\
\hline \multicolumn{2}{|l|}{ Observações por grupos: } & jxmablbk & -0.024213 & 0.009938 & -2.44 & 0.015 & -0.04369 & -0.00474 \\
\hline$-\min$ & 6 & jxmaplbk & 0.0018199 & 0.016994 & 0.11 & 0.915 & -0.031487 & 0.035127 \\
\hline - mad & 31.4 & jxmamlbk & 0.001694 & 0.005381 & 0.31 & 0.753 & -0.008852 & 0.01224 \\
\hline \multirow{2}{*}{$-\max$} & 35 & jxmamlsc & -0.003696 & 0.005463 & -0.68 & 0.499 & -0.014404 & 0.007012 \\
\hline & & jxrcblbk & 0.2155717 & 0.293437 & 0.73 & 0.463 & -0.359555 & 0.790698 \\
\hline Wald chiz: & 20035.87 & jxrcplbk & 0.0058009 & 0.018888 & 0.31 & 0.759 & -0.03122 & 0.042822 \\
\hline \multirow[t]{2}{*}{ Prob. > chi2: } & 0 & jxrcmlbk & 0.0133091 & 0.005191 & 2.56 & 0.010 & 0.0031348 & 0.023483 \\
\hline & & jxrcblsc & -0.290523 & 0.039909 & -7.28 & 0.000 & -0.368744 & -0.2123 \\
\hline sigma_u & 5882000000 & jxrcplsc & 1.071552 & 0.291533 & 3.68 & 0.000 & 0.5001581 & 1.642947 \\
\hline sigma_e & 10530000000 & jxhmmlbk & -0.042157 & 0.014679 & -2.87 & 0.004 & -0.070926 & -0.01339 \\
\hline rho (fração da variância & 0.23786612 & jxcoblsc & 0.0241599 & 0.005628 & 4.29 & 0.000 & 0.0131285 & 0.035191 \\
\hline \multirow{2}{*}{ devido a u_i) } & & jxcomlsc & 0.0055075 & 0.005303 & 1.04 & 0.299 & -0.004887 & 0.015902 \\
\hline & & cons & $2.06 \mathrm{E}+08$ & $7.30 \mathrm{E}+07$ & 2.82 & 0.005 & $6.30 \mathrm{E}+07$ & $3.49 E+08$ \\
\hline
\end{tabular}

\begin{tabular}{|c|c|c|c|c|c|c|c|}
\hline \multicolumn{2}{|l|}{ Parâmetros } & \multirow{2}{*}{ i_portfolinc } & \multirow{2}{*}{$\begin{array}{c}\text { Coef. } \\
0.0231397\end{array}$} & \multirow{2}{*}{$\begin{array}{l}\text { Std. Err. } \\
0.01959\end{array}$} & \multirow{2}{*}{$\begin{array}{rl}z & P>z \\
1.18 & 0.238\end{array}$} & \multicolumn{2}{|c|}{ [95\% Conf.Interval] } \\
\hline Tipo de regressão: & Random-effects GLS & & & & & -0.015256 & 0.061535 \\
\hline \multirow[t]{2}{*}{ Variável agrupadora: } & Pares de países (par) & mablbk & $7.27 E+09$ & $1.02 E+09$ & $7.12 \quad 0.000$ & $5.27 E+09$ & $9.26 \mathrm{E}+09$ \\
\hline & & maplbk & $6.35 \mathrm{E}+09$ & $1.30 E+09$ & $4.89 \quad 0.000$ & $3.81 E+09$ & $8.90 E+09$ \\
\hline \multicolumn{2}{|l|}{$R$-quadrado: } & mamlbk & $7.78 \mathrm{E}+09$ & $5.95 E+08$ & $13.08 \quad 0.000$ & $6.62 \mathrm{E}+09$ & $8.95 E+09$ \\
\hline - dentre & 0.0437 & mamlsc & $2.57 \mathrm{E}+07$ & $5.78 \mathrm{E}+08$ & $0.04 \quad 0.965$ & $-1.11 E+09$ & $1.16 \mathrm{E}+09$ \\
\hline - entre & 0.0177 & rcblbk & $-6.24 \mathrm{E}+11$ & $4.38 \mathrm{E}+10$ & $-14.26 \quad 0.000$ & $-7.10 \mathrm{E}+11$ & $-5.39 E+11$ \\
\hline \multirow[t]{2}{*}{ - geral } & 0.0399 & replbk & $-1.64 \mathrm{E}+10$ & $1.25 \mathrm{E}+09$ & $-13.09 \quad 0.000$ & $-1.88 \mathrm{E}+10$ & $-1.39 E+10$ \\
\hline & & rcmlbk & $-5.40 E+08$ & $3.56 \mathrm{E}+08$ & $-1.52 \quad 0.129$ & $-1.24 \mathrm{E}+09$ & $1.58 \mathrm{E}+08$ \\
\hline Efeitos alearórios $u \_i$ : & Gaussianos & rcblsc & $6.10 \mathrm{E}+11$ & $3.80 E+10$ & $16.06 \quad 0.000$ & $5.36 \mathrm{E}+11$ & $6.84 \mathrm{E}+11$ \\
\hline \multirow{2}{*}{ corr $\left(u \_i\right)$ : } & 0 (assumido) & rcplsc & $4.32 \mathrm{E}+11$ & $4.49 E+10$ & $9.63 \quad 0.000$ & $3.44 E+11$ & $5.20 \mathrm{E}+11$ \\
\hline & & hmmlbk & $1.77 \mathrm{E}+09$ & $3.40 E+08$ & $5.20 \quad 0.000$ & $1.10 \mathrm{E}+09$ & $2.43 E+09$ \\
\hline Número de obs: & 141745 & hmblsc & $-4.49 \mathrm{E}+11$ & $3.91 \mathrm{E}+10$ & $-11.48 \quad 0.000$ & $-5.25 E+11$ & $-3.72 E+11$ \\
\hline Número de grupos: & 7823 & coblsc & $1.53 \mathrm{E}+10$ & $6.91 E+08$ & $22.20 \quad 0.000$ & $1.40 \mathrm{E}+10$ & $1.67 \mathrm{E}+10$ \\
\hline \multicolumn{2}{|l|}{ Observações por grupos: } & comlsc & $1.06 \mathrm{E}+10$ & $4.84 \mathrm{E}+08$ & $21.90 \quad 0.000$ & $9.65 \mathrm{E}+09$ & $1.15 \mathrm{E}+10$ \\
\hline$-\min$ & 1 & jxmablbk & -0.011068 & 0.011598 & $-0.95 \quad 0.340$ & -0.033799 & 0.011664 \\
\hline - mad & 18.1 & jxmaplbk & -0.01048 & 0.01394 & $-0.75 \quad 0.452$ & -0.037802 & 0.016842 \\
\hline \multirow{2}{*}{$-\max$} & 36 & jxmamlbk & -0.00957 & 0.007663 & $-1.25 \quad 0.212$ & -0.02459 & 0.00545 \\
\hline & & jxmamlsc & -0.004731 & 0.007983 & $-0.59 \quad 0.553$ & -0.020378 & 0.010915 \\
\hline Wald chiz: & 6280.56 & jxrcblbk & 0.2412202 & 0.507897 & $0.47 \quad 0.635$ & -0.754239 & 1.236679 \\
\hline \multirow[t]{2}{*}{ Prob. > chi2: } & 0 & jxrcplbk & 0.0028055 & 0.020038 & $0.14 \quad 0.889$ & -0.036469 & 0.04208 \\
\hline & & jxrcmlbk & -0.004229 & 0.007858 & $-0.54 \quad 0.590$ & -0.01963 & 0.011173 \\
\hline sigma_u & 29260000000 & jxrcblsc & -0.77146 & 0.071203 & $-10.83 \quad 0.000$ & -0.911016 & -0.6319 \\
\hline sigma_e & 35750000000 & jxrcplsc & 1.09255 & 0.509416 & $2.14 \quad 0.032$ & 0.0941123 & 2.090987 \\
\hline rho (fração da variância & 0.40106411 & jxhmmlbk & -0.025809 & 0.02067 & $\begin{array}{ll}-1.25 & 0.212\end{array}$ & -0.066322 & 0.014704 \\
\hline \multirow[t]{4}{*}{ devido a u_i) } & & jxhmblsc & 0.4859888 & 0.076445 & 6.360 .000 & 0.3361588 & 0.635819 \\
\hline & & jxcoblsc & -0.011348 & 0.006136 & $-1.85 \quad 0.064$ & -0.023375 & 0.000678 \\
\hline & & jxcomlsc & 0.0029921 & 0.005735 & $0.52 \quad 0.602$ & -0.008248 & 0.014232 \\
\hline & & cons & $-1.13 E+09$ & $3.99 E+08$ & -2.820 .005 & $-1.91 E+09$ & $-3.44 E+08$ \\
\hline
\end{tabular}




\begin{tabular}{|c|c|c|c|c|c|c|c|c|}
\hline \multicolumn{2}{|l|}{ Parâmetros } & \multirow{2}{*}{\begin{tabular}{|l|} 
i_financin $\sim t$ \\
$j \_$financin $\sim t$
\end{tabular}} & Coef. & Std. Err. & $z$ & $P>z$ & {$[95 \%$ Conf } & Interval] \\
\hline Tipo de regressão: & Random-effects GLS & & 0.0202763 & 0.011263 & 1.80 & 0.072 & -0.001798 & 0.04235 \\
\hline Variável agrupadora: & Pares de países (par) & mablbk & -0.081652 & 0.396151 & -0.21 & 0.837 & -0.858093 & 0.69479 \\
\hline & & maplbk & 0.2065674 & 0.492026 & 0.42 & 0.675 & -0.757785 & 1.17092 \\
\hline R-quadrado: & & mamlbk & -0.522555 & 0.157273 & -3.32 & 0.001 & -0.830804 & -0.21431 \\
\hline - dentre & 0.0242 & mamlsc & 1.326239 & 0.152191 & 8.71 & 0.000 & 1.027951 & 1.624528 \\
\hline - entre & 0.0219 & rcblbk & -6.169999 & 1.201074 & -5.14 & 0.000 & -8.52406 & -3.81594 \\
\hline - geral & 0.0203 & rcplbk & 2.617008 & 1.206312 & 2.17 & 0.030 & 0.2526797 & 4.981335 \\
\hline & & rcmlbk & -0.416609 & 0.125667 & -3.32 & 0.001 & -0.662912 & -0.17031 \\
\hline Efeitos alearórios u_i: & Gaussianos & coblsc & -0.438881 & 0.340423 & -1.29 & 0.197 & -1.106099 & 0.228337 \\
\hline $\operatorname{corr}\left(u \_i\right)$ : & 0 (assumido) & comlsc & 0.2654904 & 0.241295 & 1.10 & 0.271 & -0.207439 & 0.73842 \\
\hline & & jxmablbk & -0.076443 & 0.071205 & -1.07 & 0.283 & -0.216002 & 0.063116 \\
\hline Número de obs: & 19974 & jxmaplbk & 0.0698406 & 0.088753 & 0.79 & 0.431 & -0.104112 & 0.243794 \\
\hline Número de grupos: & 4096 & jxmamlbk & 0.0064954 & 0.02035 & 0.32 & 0.750 & -0.03339 & 0.046381 \\
\hline Observações por grupos: & & jxmamlsc & -0.023762 & 0.020085 & -1.18 & 0.237 & -0.063128 & 0.015604 \\
\hline$-\min$ & 2 & jxrcblbk & 1.160058 & 0.147981 & 7.84 & 0.000 & 0.8700205 & 1.450097 \\
\hline - mad & 4.9 & jxrcplbk & -0.200688 & 0.157729 & $\mid-1.27$ & 0.203 & -0.50983 & 0.108455 \\
\hline$-\max$ & 5 & jxrcmlbk & 0.0414368 & 0.015 & 2.76 & 0.006 & 0.0120366 & 0.070837 \\
\hline & & jxcoblsc & 0.0326854 & 0.057065 & 0.57 & 0.567 & -0.07916 & 0.144531 \\
\hline Wald chi2: & 466.43 & jxcomlsc & -0.029901 & 0.034805 & -0.86 & 0.390 & -0.098117 & 0.038315 \\
\hline Prob. > chi2: & 0 & cons & 3.21439 & 0.105951 & 30.34 & 0.000 & 3.006731 & 3.42205 \\
\hline & & & & & & & & \\
\hline sigma_u & 3.2458387 & & & & & & & \\
\hline sigma_e & 2.9054691 & & & & & & & \\
\hline rho (fração da variância & 0.55516399 & & & & & & & \\
\hline devido a u_i) & & & & & & & & \\
\hline 23.Companhias listada & total & & & & & & & \\
\hline Parâmetros & & i_listeddonI & Coef. & Std. Err. & $z$ & $P>z$ & {$[95 \%$ Conf } & Interval] \\
\hline Tipo de regressão: & Random-effects GLS & j_listeddo I & -0.003285 & 0.00537 & -0.61 & 0.541 & -0.01381 & 0.00724 \\
\hline Variável agrupadora: & Pares de países (par) & mablbk & 11.15348 & 13.02543 & 0.86 & 0.392 & -14.37589 & 36.68286 \\
\hline & & maplbk & -182.0333 & 21.78486 & -8.36 & 0.000 & -224.7308 & -139.336 \\
\hline R-quadrado: & & mamlbk & 2.231082 & 7.13027 & 0.31 & 0.754 & -11.74399 & 16.20615 \\
\hline - dentre & 0.0694 & mamlsc & 115.269 & 7.019562 & 16.42 & 0.000 & 101.5109 & 129.0271 \\
\hline - entre & 0.0338 & rcblbk & 2602.064 & 991.2731 & 2.62 & 0.009 & 659.2046 & 4544.924 \\
\hline - geral & 0.0368 & rcplbk & 75.6794 & 21.48576 & 3.52 & 0.000 & 33.56808 & 117.7907 \\
\hline & & rcmlbk & 103.3024 & 4.875272 & $21.1 \mathrm{c}$ & 0.000 & 93.74703 & 112.8577 \\
\hline Efeitos alearórios u_i: & Gaussianos & rcblsc & -2175.525 & 652.6633 & -3.33 & 0.001 & -3454.721 & -896.328 \\
\hline corr $\left(u \_i\right)$ : & 0 (assumido) & rcplsc & -6225.921 & 1031.284 & -6.04 & 0.000 & -8247.201 & -4204.64 \\
\hline & & hmmlbk & 42.05295 & 5.809601 & 7.24 & 0.000 & 30.66634 & 53.43956 \\
\hline Número de obs: & 99542 & hmblsc & 5138.215 & 702.9133 & 7.31 & 0.000 & 3760.53 & 6515.899 \\
\hline Número de grupos: & 6368 & coblsc & 37.04015 & 10.43738 & 3.55 & 0.000 & 16.58327 & 57.49704 \\
\hline Observações por grupos: & & comlsc & 79.22516 & 6.534113 & 12.12 & 0.000 & 66.41853 & 92.03178 \\
\hline$-\min$ & 1 & jxmablbk & -0.011256 & 0.010778 & -1.04 & 0.296 & -0.03238 & 0.009868 \\
\hline - mad & 15.6 & jxmaplbk & 0.0340447 & 0.016784 & 2.03 & 0.043 & 0.0011479 & 0.066942 \\
\hline$-\max$ & 21 & jxmamlbk & -0.002851 & 0.005094 & -0.56 & 0.576 & -0.012835 & 0.007133 \\
\hline & & jxmamlsc & -0.002708 & 0.004996 & -0.54 & 0.588 & -0.012501 & 0.007085 \\
\hline Wald chi2: & 7132.01 & jxrcblbk & -0.838394 & 0.34553 & -2.43 & 0.015 & -1.51562 & -0.16117 \\
\hline Prob. > chi2: & 0 & jxrcplbk & -0.070459 & 0.020186 & -3.49 & 0.000 & -0.110023 & -0.03089 \\
\hline & & jxrcmlbk & 0.0019589 & 0.003905 & 0.50 & 0.616 & -0.005694 & 0.009612 \\
\hline sigma_u & 997.99046 & jxrcblsc & 0.4773825 & 0.156069 & 3.06 & 0.002 & 0.1714933 & 0.783272 \\
\hline sigma_e & 394.73788 & jxrcplsc & 2.425389 & 0.349697 & 6.94 & 0.000 & 1.739996 & 3.110783 \\
\hline rho (fração da variância & 0.86471819 & jxhmmlbk & -0.00691 & 0.005073 & $\mid-1.36$ & 0.173 & -0.016853 & 0.003033 \\
\hline devido a u_i) & & jxhmblsc & -1.010078 & 0.162649 & -6.21 & 0.000 & -1.328863 & -0.69129 \\
\hline & & jxcoblsc & 0.0062356 & 0.00569 & 1.10 & 0.273 & -0.004917 & 0.017388 \\
\hline & & jxcomlsc & 0.0009289 & 0.003972 & 0.23 & 0.815 & -0.006857 & 0.008715 \\
\hline & & cons & 377.2465 & 13.54202 & 27.86 & 0.000 & 350.7046 & 403.7884 \\
\hline 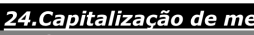 & & & & & & & & \\
\hline Parâmetros & & i marketcano & Coef. & Std. Err. & $z$ & $P>z$ & {$[95 \%$ Conf } & Interval] \\
\hline Tipo de regressão: & Random-effects GLS & j_marketca 0 & 0.214205 & 0.010216 & 20.97 & 0.000 & 0.1941827 & 0.234227 \\
\hline Variável agrupadora: & Pares de países (par) & mablbk & -12.12553 & 1.320275 & -9.18 & 0.000 & -14.71322 & -9.53784 \\
\hline & & maplbk & 0.2109973 & 1.916732 & 0.11 & 0.912 & -3.545729 & 3.967724 \\
\hline R-quadrado: & & mamlbk & 16.509 & 0.610888 & 27.02 & 0.000 & 15.31168 & 17.70632 \\
\hline - dentre & 0.2328 & mamlsc & 3.625544 & 0.601113 & 6.03 & 0.000 & 2.447383 & 4.803704 \\
\hline - entre & 0.0238 & rcblbk & 120.326 & 195.2065 & 0.62 & 0.538 & -262.2718 & 502.9237 \\
\hline - geral & 0.0752 & rcplbk & -8.606076 & 1.935001 & -4.45 & 0.000 & -12.39861 & -4.81355 \\
\hline & & rcmlbk & 9.015954 & 0.406645 & 22.17 & 0.000 & 8.218944 & 9.812963 \\
\hline Efeitos alearórios u_i: & Gaussianos & rcblsc & -65.66722 & 192.0164 & -0.34 & 0.732 & -442.0124 & 310.678 \\
\hline corr $\left(u \_i\right)$ : & 0 (assumido) & hmmlbk & 17.39108 & 0.506274 & 34.35 & 0.000 & 16.39881 & 18.38336 \\
\hline & & hmblsc & 57.53277 & 192.9622 & 0.30 & 0.766 & -320.6662 & 435.7318 \\
\hline Número de obs: & 97091 & hmplsc & -153.6615 & 196.2163 & -0.78 & 0.434 & -538.2384 & 230.9154 \\
\hline Número de grupos: & 6370 & coblsc & 1.786688 & 0.884548 & 2.02 & 0.043 & 0.0530051 & 3.52037 \\
\hline Observações por grupos: & & comlsc & 1.978648 & 0.551058 & 3.59 & 0.000 & 0.8985946 & 3.058702 \\
\hline$-\min$ & 1 & jxmablbk & 0.1322076 & 0.014006 & 9.44 & 0.000 & 0.1047559 & 0.159659 \\
\hline - mad & 15.2 & jxmaplbk & 0.0559072 & 0.031981 & 1.75 & 0.080 & -0.006775 & 0.118589 \\
\hline$-\max$ & 21 & jxmamlbk & -0.024284 & 0.006228 & -3.90 & 0.000 & -0.036491 & -0.01208 \\
\hline & & jxmamlsc & -0.00036 & 0.006277 & -0.06 & 0.954 & -0.012663 & 0.011943 \\
\hline Wald chi2: & 27357.46 & jxrcblbk & -1.065316 & 2.565061 & -0.42 & 0.678 & -6.092744 & 3.962113 \\
\hline Prob. > chi2: & 0 & jxrcplbk & 0.1097827 & 0.033047 & 3.32 & 0.001 & 0.0450109 & 0.174554 \\
\hline & & jxrcmlbk & -0.040522 & 0.005365 & -7.55 & 0.000 & -0.051037 & -0.03001 \\
\hline sigma_u & 46.622686 & jxrcblsc & 0.3920444 & 2.559371 & 0.15 & 0.878 & -4.624231 & 5.40832 \\
\hline sigma_e & 28.255191 & jxrcplsc & 1.418628 & 2.56928 & 0.55 & 0.581 & -3.617068 & 6.454324 \\
\hline rho (fração da variância & 0.73137699 & jxhmmlbk & -0.060776 & 0.010046 & -6.05 & 0.000 & -0.080465 & -0.04109 \\
\hline devido a u_i) & & jxhmblsc & -0.235818 & 2.563455 & -0.09 & 0.927 & -5.260097 & 4.788461 \\
\hline & & jxcoblsc & 0.0738822 & 0.007493 & 9.86 & 0.000 & 0.0591963 & 0.088568 \\
\hline & & jxcomlsc & 0.0304188 & 0.005228 & 5.82 & 0.000 & 0.0201718 & 0.040666 \\
\hline & & _cons & 11.68365 & 0.734332 & 15.91 & 0.000 & 10.24439 & 13.12292 \\
\hline
\end{tabular}




\begin{tabular}{|c|c|c|c|c|c|c|c|c|}
\hline \multicolumn{2}{|l|}{ Parâmetros } & i_marketcans & Coef. & Std. Err. & $z \quad F$ & $P>z$ & {$[95 \%$ Conf } & Interval] \\
\hline Tipo de regressão: & Random-effects GLS & & 0.0795119 & 0.013773 & $5.77 \quad 0$ & 0.000 & 0.0525183 & 0.106506 \\
\hline Variável agrupadora: & Pares de países (par) & mablbk & $1.54 \mathrm{E}+11$ & $2.06 \mathrm{E}+10$ & $7.47 \quad 0$. & 0.000 & $1.14 \mathrm{E}+11$ & $1.95 \mathrm{E}+11$ \\
\hline & & maplbk & $-1.46 E+10$ & $3.37 E+10$ & -0.430 & 0.664 & $-8.08 \mathrm{E}+10$ & $5.15 E+10$ \\
\hline R-quadrado: & & mamlbk & $1.10 \mathrm{E}+11$ & $1.15 \mathrm{E}+10$ & $9.64 \quad 0$ & 0.000 & $8.80 E+10$ & $1.33 \mathrm{E}+11$ \\
\hline - dentre & 0.0975 & mamlsc & $1.74 \mathrm{E}+11$ & $1.13 \mathrm{E}+10$ & 15.44 & 0.000 & $1.52 \mathrm{E}+11$ & $1.96 \mathrm{E}+11$ \\
\hline - entre & 0.0455 & rcblbk & $-1.12 \mathrm{E}+12$ & $1.20 \mathrm{E}+12$ & -0.930 & 0.351 & $-3.48 \mathrm{E}+12$ & $1.23 \mathrm{E}+12$ \\
\hline - geral & 0.0587 & rcmlbk & $1.45 \mathrm{E}+11$ & $8.04 \mathrm{E}+09$ & 17.99 & 0.000 & $1.29 \mathrm{E}+11$ & $1.60 \mathrm{E}+11$ \\
\hline & & rcblsc & $7.35 \mathrm{E}+11$ & $7.43 E+11$ & 0.990 & 0.323 & $-7.22 \mathrm{E}+11$ & $2.19 E+12$ \\
\hline Efeitos alearórios u_i: & Gaussianos & rcplsc & $-4.95 E+12$ & $1.26 \mathrm{E}+12$ & -3.940 & 0.000 & $-7.42 \mathrm{E}+12$ & $-2.49 E+12$ \\
\hline corr $\left(u \_i\right)$ : & 0 (assumed) & hmplbk & $-1.92 \mathrm{E}+11$ & $3.38 \mathrm{E}+10$ & -5.670 & 0.000 & $-2.58 \mathrm{E}+11$ & $-1.25 \mathrm{E}+11$ \\
\hline & & hmmlbk & $5.55 \mathrm{E}+10$ & $9.66 \mathrm{E}+09$ & $5.75 \quad 0$. & 0.000 & $3.66 \mathrm{E}+10$ & $7.44 E+10$ \\
\hline Número de obs: & 97387 & hmblsc & $4.29 \mathrm{E}+12$ & $8.17 E+11$ & 5.260 & 0.000 & $2.69 E+12$ & $5.90 E+12$ \\
\hline Número de grupos: & 6370 & coblsc & $3.61 \mathrm{E}+11$ & $1.64 \mathrm{E}+10$ & 21.99 & 0.000 & $3.29 E+11$ & $3.93 E+11$ \\
\hline Observações por grupos: & & comlsc & $1.67 E+11$ & $9.96 \mathrm{E}+09$ & 16.72 & 0.000 & $1.47 E+11$ & $1.86 \mathrm{E}+11$ \\
\hline$-\min$ & 1 & jxmablbk & -0.026861 & 0.009348 & $-2.87 \mathrm{c}$ & 0.004 & -0.045184 & -0.00854 \\
\hline - mad & 15.3 & jxmaplbk & -0.010446 & 0.016285 & $-0.64 \quad 0 \quad r y-10$ & 0.521 & -0.042363 & 0.021472 \\
\hline$-\max$ & 21 & jxmamlbk & -0.007807 & 0.00549 & -1.420 & 0.155 & -0.018567 & 0.002953 \\
\hline & & jxmamlsc & -0.008222 & 0.005607 & -1.470 & 0.143 & -0.019211 & 0.002767 \\
\hline Wald chi2: & 10094.99 & jxrcblbk & -0.866729 & 0.470398 & -1.840 & 0.065 & -1.788691 & 0.055234 \\
\hline Prob. > chi2: & 0 & jxrcmlbk & -0.021002 & 0.007447 & -2.82 & 0.005 & -0.035597 & -0.00641 \\
\hline & & jxrcblsc & -0.066625 & 0.089968 & $-0.74 \quad c$ & 0.459 & -0.242959 & 0.10971 \\
\hline sigma_u & $1.317 E+12$ & jxrcplsc & 1.980571 & 0.472786 & 4.190 & 0.000 & 1.053927 & 2.907215 \\
\hline sigma_e & $6.816 \mathrm{E}+11$ & jxhmplbk & -0.020087 & 0.028457 & -0.71 & 0.480 & -0.075862 & 0.035688 \\
\hline rho (fração da variância & 0.78862786 & jxhmmlbk & -0.055079 & 0.012876 & -4.28 & 0.000 & -0.080315 & -0.02984 \\
\hline devido a u_i) & & jxhmblsc & -0.012527 & 0.095496 & -0.13 & 0.896 & -0.199695 & 0.174642 \\
\hline & & jxcoblsc & 0.0268852 & 0.005544 & 4.850 & 0.000 & 0.0160184 & 0.037752 \\
\hline & & jxcomlsc & 0.008415 & 0.004048 & $2.08 \quad 0$ & 0.038 & 0.0004814 & 0.016349 \\
\hline & & cons & $8.51 \mathrm{E}+10$ & $1.85 \mathrm{E}+10$ & 4.610 & 0.000 & $4.89 \mathrm{E}+10$ & $1.21 \mathrm{E}+11$ \\
\hline 26.Crédito pri & ( LCU corrente) & & & & & & & \\
\hline Parâmetros & & i_netdomesnu & Coef. & Std. Err. & $z \quad t$ & $P>z$ & {$[95 \%$ Conf } & Interval] \\
\hline Tipo de regressão: & Random-effects GLS & j_netdomes u & -0.034083 & 0.662832 & -0.05 & 0.959 & -1.33321 & 1.265044 \\
\hline Variável agrupadora: & Pares de países (par) & mablbk & $-1.95 \mathrm{E}+14$ & $3.65 E+14$ & -0.54 & 0.592 & $-9.10 \mathrm{E}+14$ & $5.19 \mathrm{E}+14$ \\
\hline & & maplbk & $-1.80 E+14$ & $3.59 E+14$ & -0.50 & 0.616 & $-8.84 E+14$ & $5.24 E+14$ \\
\hline$R$-quadrado: & & mamlbk & $5.72 \mathrm{E}+15$ & $1.50 \mathrm{E}+14$ & 38.06 & 0.000 & $5.43 E+15$ & $6.02 E+15$ \\
\hline - dentre & 0.017 & mamlsc & $-5.16 \mathrm{E}+15$ & $1.51 \mathrm{E}+14$ & -34.23 & 0.000 & $-5.45 E+15$ & $-4.86 \mathrm{E}+15$ \\
\hline - entre & 0.0737 & rcblbk & $1.04 \mathrm{E}+14$ & $1.14 \mathrm{E}+16$ & 0.010 & 0.993 & $-2.23 E+16$ & $2.25 E+16$ \\
\hline - geral & 0.0195 & rcplbk & $-6.47 E+14$ & $4.49 E+14$ & -1.44 & 0.149 & $-1.53 E+15$ & $2.33 E+14$ \\
\hline & & rcmlbk & $1.05 \mathrm{E}+15$ & $9.29 \mathrm{E}+13$ & 11.25 & 0.000 & $8.63 E+14$ & $1.23 E+15$ \\
\hline Efeitos alearórios $u \_i$ : & Gaussianos & rcblsc & $-2.75 E+14$ & $1.12 \mathrm{E}+16$ & -0.02 & 0.980 & $-2.22 E+16$ & $2.17 E+16$ \\
\hline $\operatorname{corr}\left(u \_i\right):$ & 0 (assumed) & rcplsc & $5.41 \mathrm{E}+14$ & $1.10 \mathrm{E}+16$ & $0.05 \quad 0$ & 0.961 & $-2.10 \mathrm{E}+16$ & $2.20 \mathrm{E}+16$ \\
\hline & & hmmlbk & $-5.23 E+13$ & $8.34 \mathrm{E}+13$ & -0.63 & 0.531 & $-2.16 \mathrm{E}+14$ & $1.11 \mathrm{E}+14$ \\
\hline Número de obs: & 225359 & hmblsc & $3.06 \mathrm{E}+14$ & $1.07 E+16$ & 0.030 & 0.977 & $-2.07 E+16$ & $2.13 E+16$ \\
\hline Número de grupos: & 7921 & coblsc & $-4.13 E+14$ & $1.98 \mathrm{E}+14$ & -2.09 & 0.037 & $-8.01 E+14$ & $-2.53 E+13$ \\
\hline Observações por grupos: & & comlsc & $-8.27 E+14$ & $1.65 \mathrm{E}+14$ & -5.02 & 0.000 & $-1.15 E+15$ & $-5.04 E+14$ \\
\hline$-\min$ & 9 & jxmablbk & 0.3843838 & 1.625557 & $0.24 \quad 0$ & 0.813 & -2.801649 & 3.570416 \\
\hline - mad & 28.5 & jxmaplbk & -35.47611 & 83.37652 & -0.43 & 0.670 & -198.8911 & 127.9389 \\
\hline$-\max$ & 36 & jxmamlbk & -0.007486 & 0.005694 & -1.31 & 0.189 & -0.018645 & 0.003673 \\
\hline & & jxmamlsc & 0.0067488 & 0.005799 & 1.160 & 0.245 & 04618 & 0.018116 \\
\hline Wald chi2: & 4385.86 & jxrcblbk & -48.76101 & 552.7634 & -0.09 & 0.930 & -1132.157 & 1034.635 \\
\hline Prob. > chi2: & 0 & jxrcplbk & 64.44669 & 122.6531 & 0.530 & 0.599 & -175.9489 & 304.8423 \\
\hline & & jxrcmlbk & -0.001306 & 0.005894 & -0.22 & 0.825 & -0.012858 & 0.010246 \\
\hline sigma_u & $1.272 \mathrm{E}+15$ & jxrcblsc & 20.76546 & 545.3742 & $0.04 \quad 0$ & 0.970 & 8.148 & 1089.679 \\
\hline sigma_e & $1.443 E+16$ & jxhmmlbk & 0.0342234 & 0.662855 & $0.05 \quad 0$ & 0.959 & -1.264949 & 1.333396 \\
\hline rho (fração da variância & 0.00771538 & jxcoblsc & -0.194849 & 1.094828 & -0.18 & 0.859 & -2.340671 & 1.950974 \\
\hline devido a u_i) & & jxcomlsc & -0.16267 & 0.802284 & -0.20 & 0.839 & -1.735118 & 1.409777 \\
\hline & & cons & $2.68 \mathrm{E}+13$ & $5.04 \mathrm{E}+13$ & $0.53 \quad 0$ & 0.595 & $-7.20 \mathrm{E}+13$ & $1.26 \mathrm{E}+14$ \\
\hline & & & & & & & & \\
\hline Parâmetros & & i_netforeinu & Coef. & Std. Err. & $z+1$ & $P>z$ & {$[95 \%$ Conf } & Interval] \\
\hline Tipo de regressão: & Random-effects GLS & j_netforei u & 0.0476403 & 0.099466 & $0.48 \quad 0$ & 0.632 & -0.14731 & 0.24259 \\
\hline Variável agrupadora: & Pares de países (par) & mablbk & $5.34 \mathrm{E}+12$ & $1.49 \mathrm{E}+12$ & 3.590 & 0.000 & $2.42 E+12$ & $8.25 E+12$ \\
\hline & & maplbk & $-2.36 \mathrm{E}+12$ & $1.67 \mathrm{E}+12$ & -1.41 & 0.157 & $-5.63 E+12$ & $9.11 \mathrm{E}+11$ \\
\hline R-quadrado: & & mamlbk & $-1.15 E+13$ & $6.52 E+11$ & -17.70 & 0.000 & $-1.28 \mathrm{E}+13$ & $-1.03 E+13$ \\
\hline - dentre & 0.0212 & mamlsc & $1.92 \mathrm{E}+13$ & $6.52 \mathrm{E}+11$ & 29.45 & 0.000 & $1.79 E+13$ & $2.05 E+13$ \\
\hline - entre & 0.0241 & rcblbk & $-2.49 \mathrm{E}+12$ & $4.31 \mathrm{E}+13$ & -0.06 & 0.954 & $-8.69 E+13$ & $8.19 E+13$ \\
\hline - geral & 0.0223 & rcplbk & $-7.49 \mathrm{E}+12$ & $1.81 \mathrm{E}+12$ & -4.15 & 0.000 & $-1.10 \mathrm{E}+13$ & $-3.95 E+12$ \\
\hline & & rcmlbk & $3.46 \mathrm{E}+12$ & $4.17 E+11$ & 8.300 & 0.000 & $2.64 E+12$ & $4.27 E+12$ \\
\hline Efeitos alearórios $u \_i$ : & Gaussianos & rcblsc & $-6.92 \mathrm{E}+12$ & $4.08 \mathrm{E}+13$ & -0.17 & 0.865 & $-8.69 E+13$ & $7.31 \mathrm{E}+13$ \\
\hline corr $\left(u \_i\right)$ : & 0 (assumed) & rcplsc & $1.12 \mathrm{E}+13$ & $4.49 E+13$ & 0.250 & 0.802 & $-7.68 \mathrm{E}+13$ & $9.93 E+13$ \\
\hline & & hmmlbk & $3.49 E+12$ & $3.66 \mathrm{E}+11$ & 9.540 & 0.000 & $2.77 E+12$ & $4.21 \mathrm{E}+12$ \\
\hline Número de obs: & 226276 & hmblsc & $-1.51 \mathrm{E}+12$ & $4.27 E+13$ & -0.04 & 0.972 & $-8.51 E+13$ & $8.21 E+13$ \\
\hline Número de grupos: & 7921 & coblsc & $-2.30 \mathrm{E}+12$ & $8.91 \mathrm{E}+11$ & -2.58 & 0.010 & $-4.04 \mathrm{E}+12$ & $-5.49 E+11$ \\
\hline Observações por grupos: & & comlsc & $-8.65 E+12$ & $6.97 \mathrm{E}+11$ & -12.42 & 0.000 & $-1.00 \mathrm{E}+13$ & $-7.29 E+12$ \\
\hline$-\min$ & 9 & jxmablbk & 0.1201519 & 0.025054 & 4.800 & 0.000 & 0.0710466 & 0.169257 \\
\hline - mad & 28.6 & jxmaplbk & -0.303007 & 1.206917 & -0.25 & 0.802 & -2.668521 & 2.062508 \\
\hline$-\max$ & 36 & jxmamlbk & -0.001347 & 0.00569 & -0.24 & 0.813 & -0.0125 & 0.009805 \\
\hline & & jxmamlsc & -0.00748 & 0.005814 & -1.29 & 0.198 & -0.018875 & 0.003914 \\
\hline Wald chi2: & 4939.15 & jxrcblbk & 9.063685 & 206.9943 & $0.04 \quad 0$ & 0.965 & -396.6377 & 414.765 \\
\hline Prob. > chi2: & 0 & jxrcplbk & 0.3706657 & 3.277371 & 0.110 & 0.910 & -6.052864 & 6.794196 \\
\hline & & jxrcmlbk & -0.010147 & 0.005719 & -1.77 & 0.076 & -0.021355 & 0.001062 \\
\hline sigma_u & $1.865 \mathrm{E}+13$ & jxrcblsc & -0.95777 & 158.8397 & -0.01 & 0.995 & -312.2778 & 310.3623 \\
\hline sigma_e & $5.612 \mathrm{E}+13$ & jxrcplsc & -1.169491 & 218.9469 & -0.01 & 0.996 & -430.2976 & 427.9586 \\
\hline rho (fração da variância & 0.09945501 & jxhmmlbk & -0.029735 & 0.099575 & -0.30 & 0.765 & -0.224897 & 0.165428 \\
\hline devido a u_i) & & jxhmblsc & -6.021426 & 174.0934 & -0.03 & 0.972 & -347.2383 & 335.1954 \\
\hline & & jxcoblsc & -0.054856 & 0.021385 & -2.57 & 0.010 & -0.096769 & -0.01294 \\
\hline & & jxcomlsc & -0.046887 & 0.071538 & -0.66 & 0.512 & -0.187098 & 0.093325 \\
\hline & & _cons & $5.39 \mathrm{E}+11$ & $2.93 \mathrm{E}+11$ & $1.84 \quad 0$ & 0.066 & $-3.53 E+10$ & $1.11 \mathrm{E}+12$ \\
\hline
\end{tabular}




\begin{tabular}{|c|c|c|c|c|c|c|c|c|}
\hline \multicolumn{2}{|l|}{ Parâmetros } & \multirow{2}{*}{$\begin{array}{c}\text { i_spglobalna } \\
\text { j_spglobal a }\end{array}$} & Coef. & Std. Err. & $z$ & $P>z$ & {$[95 \%$ Conf } & Interval] \\
\hline Tipo de regressão: & Random-effects GLS & & 0.2192399 & 0.014685 & 14.93 & 0.000 & 0.1904578 & 0.248022 \\
\hline Variável agrupadora: & Pares de países (par) & mablbk & -16.04342 & 3.614327 & -4.44 & 0.000 & -23.12737 & -8.95947 \\
\hline & & maplbk & -2.9552 & 6.739988 & -0.44 & 0.661 & -16.16533 & 10.25493 \\
\hline R-quadrado: & & mamlbk & 9.451631 & 1.099247 & 8.60 & 0.000 & 7.297147 & 11.60611 \\
\hline - dentre & 0.0824 & mamlsc & -5.077027 & 1.055451 & -4.81 & 0.000 & -7.145674 & -3.00838 \\
\hline - entre & 0.101 & rcblbk & -0.456546 & 5.166852 & -0.09 & 0.930 & -10.58339 & 9.670298 \\
\hline - geral & 0.0785 & rcplbk & 7.497061 & 7.585539 & 0.99 & 0.323 & -7.370322 & 22.36444 \\
\hline & & rcmlbk & 0.0753306 & 1.092657 & 0.07 & 0.945 & -2.066237 & 2.216899 \\
\hline Efeitos alearórios u_i: & Gaussianos & coblsc & -5.330425 & 1.572549 & -3.39 & 0.001 & -8.412565 & -2.24829 \\
\hline $\operatorname{corr}\left(u \_i\right)$ : & 0 (assumed) & comlsc & 1.639571 & 1.315979 & 1.25 & 0.213 & -0.939701 & 4.218843 \\
\hline & & jxmablbk & 0.4755375 & 0.084012 & 5.66 & 0.000 & 0.3108775 & 0.640197 \\
\hline Número de obs: & 23121 & jxmaplbk & 0.0772414 & 0.150698 & 0.51 & 0.608 & -0.218122 & 0.372604 \\
\hline Número de grupos: & 2280 & jxmamlbk & -0.035653 & 0.016473 & -2.16 & 0.030 & -0.06794 & -0.00337 \\
\hline Observações por grupos: & & jxmamlsc & 0.0089911 & 0.016504 & 0.54 & 0.586 & -0.023356 & 0.041338 \\
\hline$-\min$ & 1 & jxrcblbk & -0.152992 & 0.115526 & -1.32 & 0.185 & -0.379419 & 0.073435 \\
\hline - mad & 10.1 & jxrcplbk & 0.0221627 & 0.167615 & 0.13 & 0.895 & -0.306356 & 0.350681 \\
\hline$-\max$ & 13 & jxrcmlbk & -0.058139 & 0.01641 & -3.54 & 0.000 & -0.090302 & -0.02598 \\
\hline & & jxcoblsc & 0.193952 & 0.035099 & 5.53 & 0.000 & 0.1251584 & 0.262746 \\
\hline Wald chi2: & 1967.65 & jxcomlsc & 0.2496595 & 0.024832 & 10.05 & 0.000 & 0.2009907 & 0.298328 \\
\hline Prob. > chi2: & 0 & cons & 11.19902 & 1.003901 & 11.16 & 0.000 & 9.231412 & 13.16663 \\
\hline & & & & & & & & \\
\hline sigma_u & ton 010081 & & & & & & & \\
\hline sigma_e & 60.949981 & & & & & & & \\
\hline rho (fração da variância & 0 & & & & & & & \\
\hline devido a u_i) & & & & & & & & \\
\hline 29.Ações & 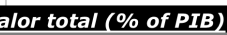 & & & & & & & \\
\hline Parâmetros & & j_stockstr pp & Coef. & Std. Err. & $z$ & $P>z$ & {$[95 \%$ Conf } & Interval] \\
\hline Tipo de regressão: & Random-effects GLS & j_stockstr $\sim p$ & 0.2274568 & 0.022884 & 9.94 & 0.000 & 0.1826043 & 0.272309 \\
\hline Variável agrupadora: & Pares de países (par) & mablbk & 20.17583 & 1.17607 & 17.16 & 0.000 & 17.87078 & 22.48088 \\
\hline & & maplbk & -5.211455 & 1.62521 & -3.21 & 0.001 & -8.396809 & -2.0261 \\
\hline R-quadrado: & & mamlbk & 14.01357 & 0.594096 & 23.59 & 0.000 & 12.84916 & 15.17798 \\
\hline - dentre & 0.258 & mamlsc & 12.58918 & 0.584364 & 21.54 & 0.000 & 11.44385 & 13.73451 \\
\hline - entre & 0.0904 & rcblbk & -124.5843 & 61.5291 & -2.02 & 0.043 & -245.1792 & -3.98951 \\
\hline - geral & 0.1562 & rcplbk & 1.644115 & 1.624213 & 1.01 & 0.311 & -1.539284 & 4.827513 \\
\hline & & rcmlbk & 10.05963 & 0.39901 & 25.21 & 0.000 & 9.277588 & 10.84168 \\
\hline Efeitos alearórios u_i: & Gaussianos & rcblsc & 123.1567 & 54.76011 & 2.25 & 0.025 & 15.82883 & 230.4845 \\
\hline corr $\left(u_{i} i\right)$ : & 0 (assumed) & rcplsc & 23.6172 & 63.39797 & 0.37 & 0.710 & -100.6405 & 147.8749 \\
\hline & & hmmlbk & 10.30146 & 0.499389 & 20.63 & 0.000 & 9.32268 & 11.28025 \\
\hline Número de obs: & 94163 & hmblsc & -90.58447 & 56.66727 & -1.60 & 0.110 & -201.6503 & 20.48134 \\
\hline Número de grupos: & 6076 & coblsc & -3.301002 & 0.830003 & -3.98 & 0.000 & -4.927777 & -1.67423 \\
\hline Observações por grupos: & & comlsc & 6.332623 & 0.550703 & 11.50 & 0.000 & 5.253265 & 7.411982 \\
\hline$-\min$ & 1 & jxmablbk & -0.038279 & 0.012148 & -3.15 & 0.002 & -0.062087 & -0.01447 \\
\hline - mad & 15.5 & jxmaplbk & -0.084759 & 0.025079 & -3.38 & 0.001 & -0.133912 & -0.03561 \\
\hline$-\max$ & 21 & jxmamlbk & 0.0005089 & 0.006984 & 0.07 & 0.942 & -0.013179 & 0.014197 \\
\hline & & jxmamlsc & -0.014515 & 0.00714 & -2.03 & 0.042 & -0.028508 & -0.00052 \\
\hline Wald chi2: & 31101.06 & jxrcblbk & -0.062359 & 0.327683 & -0.19 & 0.849 & -0.704606 & 0.579888 \\
\hline Prob. > chi2: & 0 & jxrcplbk & 0.0875956 & 0.025814 & 3.39 & 0.001 & 0.0370013 & 0.13819 \\
\hline & & jxrcmlbk & -0.007596 & 0.007773 & -0.98 & 0.328 & -0.022832 & 0.007639 \\
\hline sigma_u & 38.188344 & jxrcblsc & -0.554233 & 0.281286 & -1.97 & 0.049 & -1.105543 & -0.00292 \\
\hline sigma_e & 30.369008 & jxrcplsc & 0.7023478 & 0.336552 & 2.09 & 0.037 & 0.0427184 & 1.361977 \\
\hline rho (fração da variância & 0.61259074 & jxhmmlbk & -0.165745 & 0.023233 & -7.13 & 0.000 & -0.211281 & -0.12021 \\
\hline devido a u_i) & & jxhmblsc & 0.6834493 & 0.290379 & 2.35 & 0.019 & 0.1143177 & 1.252581 \\
\hline & & jxcoblsc & 0.1910628 & 0.007862 & 24.30 & 0.000 & 0.1756532 & 0.206473 \\
\hline & & jxcomlsc & 0.0350647 & 0.006093 & 5.75 & 0.000 & 0.0231228 & 0.047007 \\
\hline & & cons & 1.790977 & 0.644146 & 2.78 & 0.005 & 0.5284739 & 3.05348 \\
\hline 0.Acóe & & & & & & & & \\
\hline Parâmetros & & i_stockstr u & Coef. & Std. Err. & $z$ & $P>z$ & {$[95 \%$ Conf } & Interval] \\
\hline Tipo de regressão: & Random-effects GLS & j_stockstr u & 0.1495294 & 0.047807 & 3.13 & 0.002 & 0.0558296 & 0.243229 \\
\hline Variável agrupadora: & Pares de países (par) & mablbk & $5.22 \mathrm{E}+11$ & $4.71 \mathrm{E}+10$ & 11.10 & 0.000 & $4.30 E+11$ & $6.15 \mathrm{E}+11$ \\
\hline & & maplbk & $-6.09 E+10$ & $7.59 E+10$ & -0.80 & 0.422 & $-2.10 E+11$ & $8.78 \mathrm{E}+10$ \\
\hline R-quadrado: & & mamlbk & $3.46 \mathrm{E}+11$ & $2.59 E+10$ & 13.36 & 0.000 & $2.95 \mathrm{E}+11$ & $3.97 E+11$ \\
\hline - dentre & 0.0775 & mamlsc & $3.36 \mathrm{E}+11$ & $2.56 \mathrm{E}+10$ & 13.15 & 0.000 & $2.86 \mathrm{E}+11$ & $3.86 \mathrm{E}+11$ \\
\hline - entre & 0.0452 & rcblbk & $-2.29 E+13$ & $2.18 \mathrm{E}+12$ & -10.52 & 20.000 & $-2.72 E+13$ & $-1.86 \mathrm{E}+13$ \\
\hline - geral & 0.0615 & rcplbk & $-5.07 E+11$ & $7.38 \mathrm{E}+10$ & -6.87 & 0.000 & $-6.52 E+11$ & $-3.63 E+11$ \\
\hline & & rcmlbk & $1.75 \mathrm{E}+11$ & $1.85 \mathrm{E}+10$ & 9.48 & 0.000 & $1.39 \mathrm{E}+11$ & $2.11 \mathrm{E}+11$ \\
\hline Efeitos alearórios u_i: & Gaussianos & rcblsc & $2.18 \mathrm{E}+13$ & $1.66 \mathrm{E}+12$ & 13.14 & 0.000 & $1.85 \mathrm{E}+13$ & $2.50 E+13$ \\
\hline corr $\left(u \_i\right)$ : & 0 (assumed) & rcplsc & $1.28 \mathrm{E}+13$ & $2.30 \mathrm{E}+12$ & 5.57 & 0.000 & $8.28 \mathrm{E}+12$ & $1.73 \mathrm{E}+13$ \\
\hline & & hmmlbk & $1.46 \mathrm{E}+10$ & $2.27 \mathrm{E}+10$ & 0.64 & 0.519 & $-2.98 \mathrm{E}+10$ & $5.91 \mathrm{E}+10$ \\
\hline Número de obs: & 94455 & hmblsc & $-1.34 \mathrm{E}+13$ & $1.79 \mathrm{E}+12$ & -7.49 & 0.000 & $-1.70 E+13$ & $-9.93 E+12$ \\
\hline Número de grupos: & 6076 & coblsc & $6.07 E+11$ & $3.66 \mathrm{E}+10$ & 16.57 & 0.000 & $5.35 \mathrm{E}+11$ & $6.79 E+11$ \\
\hline Observações por grupos: & & comlsc & $3.46 \mathrm{E}+11$ & $2.25 \mathrm{E}+10$ & 15.41 & 0.000 & $3.02 \mathrm{E}+11$ & $3.90 E+11$ \\
\hline$-\min$ & 1 & jxmablbk & -0.041235 & 0.01172 & -3.52 & 0.000 & -0.064206 & -0.01826 \\
\hline - mad & 15.5 & jxmaplbk & -0.040638 & 0.022324 & -1.82 & 0.069 & -0.084393 & 0.003116 \\
\hline$-\max$ & 21 & jxmamlbk & -0.002637 & 0.007076 & -0.37 & 0.709 & -0.016506 & 0.011232 \\
\hline & & jxmamlsc & -0.012751 & 0.007597 & -1.68 & 0.093 & -0.02764 & 0.002139 \\
\hline Wald chi2: & 7700.86 & jxrcblbk & -0.953056 & 0.988554 & -0.96 & 0.335 & -2.890586 & 0.984474 \\
\hline Prob. > chi2: & 0 & jxrcplbk & -0.02442 & 0.036894 & -0.66 & 0.508 & -0.096731 & 0.047891 \\
\hline & & jxrcmlbk & -0.008104 & 0.011014 & -0.74 & 0.462 & -0.029691 & 0.013484 \\
\hline sigma_u & $1.954 \mathrm{E}+12$ & jxrcblsc & -0.588033 & 0.064967 & -9.05 & 0.000 & -0.715365 & -0.4607 \\
\hline sigma_e & $1.572 \mathrm{E}+12$ & jxrcplsc & 2.066868 & 0.990017 & 2.09 & 0.037 & 0.1264703 & 4.007265 \\
\hline rho (fração da variância & 0.60717806 & jxhmmlbk & -0.152406 & 0.047728 & -3.19 & 0.001 & -0.245951 & -0.05886 \\
\hline devido a u_i) & & jxhmblsc & 0.5604028 & 0.073435 & 7.63 & 0.000 & 0.416472 & 0.704334 \\
\hline & & jxcoblsc & 0.0393027 & 0.006548 & 6.00 & 0.000 & 0.0264681 & 0.052137 \\
\hline & & jxcomlsc & 0.0071767 & 0.005231 & 1.37 & 0.170 & -0.003077 & 0.01743 \\
\hline & & _cons & $8.18 \mathrm{E}+09$ & $3.12 \mathrm{E}+10$ & 0.26 & 0.793 & $-5.30 E+10$ & $6.94 \mathrm{E}+10$ \\
\hline
\end{tabular}


31.Acões negociadas, giro (\%)

\begin{tabular}{|c|c|c|c|c|c|c|c|c|}
\hline \multicolumn{2}{|l|}{ Parâmetros } & \multirow{2}{*}{\begin{tabular}{|l} 
i_stockstr $\sim 0$ \\
j_stockstr $\sim 0$
\end{tabular}} & \multirow{2}{*}{$\frac{\text { Coef. }}{0.0431083}$} & \multirow{2}{*}{$\frac{\text { Std. Err. }}{0.024449}$} & \multirow{2}{*}{$\frac{z}{1.76}$} & \multirow{2}{*}{$\frac{P>z}{0.078}$} & \multicolumn{2}{|c|}{ [95\% Conf.Interval] } \\
\hline Tipo de regressão: & Random-effects GLS & & & & & & -0.004811 & 0.091028 \\
\hline \multirow[t]{2}{*}{ Variável agrupadora: } & Pares de países (par) & mablbk & 21.74493 & 1.811603 & 12.00 & 0.000 & 18.19426 & 25.29561 \\
\hline & & maplbk & 0.9733123 & 3.505134 & 0.28 & 0.781 & -5.896624 & 7.843249 \\
\hline \multicolumn{2}{|l|}{ R-quadrado: } & mamlbk & 8.317133 & 0.860961 & 9.66 & 0.000 & 6.629679 & 10.00459 \\
\hline - dentre & 0.0825 & mamlsc & 4.303317 & 0.842275 & 5.11 & 0.000 & 2.652488 & 5.954145 \\
\hline - entre & 0.0562 & rcblbk & -121.8167 & 81.93921 & -1.49 & 0.137 & -282.4146 & 38.78124 \\
\hline \multirow[t]{2}{*}{ - geral } & 0.0625 & rcmlbk & 1.769719 & 0.823396 & 2.15 & 0.032 & 0.1558924 & 3.383545 \\
\hline & & rcblsc & 114.6891 & 72.36934 & 1.58 & 0.113 & -27.15214 & 256.5304 \\
\hline Efeitos alearórios u_i: & Gaussianos & rcplsc & 13.97259 & 86.98218 & 0.16 & 0.872 & -156.5093 & 184.4545 \\
\hline \multirow[t]{2}{*}{ corr $\left(u \_i\right)$ : } & 0 (assumed) & hmplbk & -3.336184 & 3.643756 & -0.92 & 0.360 & -10.47781 & 3.805446 \\
\hline & & hmmlbk & 21.17959 & 1.269747 & 16.68 & 0.000 & 18.69093 & 23.66825 \\
\hline Número de obs: & 70180 & hmblsc & -82.69548 & 77.82523 & -1.06 & 0.288 & -235.2301 & 69.83916 \\
\hline Número de grupos: & 6076 & coblsc & -12.16081 & 1.36244 & -8.93 & 0.000 & -14.83114 & -9.49048 \\
\hline \multicolumn{2}{|l|}{ Observações por grupos: } & comlsc & 9.445533 & 0.840142 & 11.24 & 0.000 & 7.798885 & 11.09218 \\
\hline$-\min$ & 1 & jxmablbk & -0.010414 & 0.017894 & -0.58 & 0.561 & -0.045486 & 0.024658 \\
\hline - med & 11.6 & jxmaplbk & -0.20423 & 0.041201 & -4.96 & 0.000 & -0.284983 & -0.12348 \\
\hline \multirow[t]{2}{*}{$-\max$} & 21 & jxmamlbk & 0.0077995 & 0.008669 & 0.90 & 0.368 & -0.009191 & 0.02479 \\
\hline & & jxmamlsc & -0.032831 & 0.008843 & -3.71 & 0.000 & -0.050163 & -0.0155 \\
\hline Wald chi2: & 6077.73 & jxrcblbk & 0.2123682 & 0.542785 & 0.39 & 0.696 & -0.85147 & 1.276206 \\
\hline \multirow[t]{2}{*}{ Prob. > chi2: } & 0 & jxrcplbk & 0.1953334 & 0.041283 & 4.73 & 0.000 & 0.1144207 & 0.276246 \\
\hline & & jxrcmlbk & 0.0320912 & 0.009098 & 3.53 & 0.000 & 0.0142586 & 0.049924 \\
\hline sigma_u & 45.947697 & jxrcblsc & -0.502586 & 0.403018 & -1.25 & 0.212 & -1.292487 & 0.287314 \\
\hline sigma_e & 35.476004 & jxrcplsc & 0.405122 & 0.571521 & 0.71 & 0.478 & -0.715039 & 1.525283 \\
\hline \multirow{5}{*}{$\begin{array}{l}\text { rho (fração da variância } \\
\text { devido a u_i) }\end{array}$} & 0.62651489 & jxhmmlbk & -0.048325 & 0.025377 & -1.90 & 0.057 & -0.098064 & 0.001413 \\
\hline & & jxhmblsc & 0.7483876 & 0.439706 & 1.70 & 0.089 & -0.11342 & 1.610196 \\
\hline & & jxcoblsc & 0.1323944 & 0.012881 & 10.28 & 0.000 & 0.1071473 & 0.157641 \\
\hline & & jxcomlsc & 0.0217826 & 0.008831 & 2.47 & 0.014 & 0.0044738 & 0.039091 \\
\hline & & cons & 23.61386 & 1.23441 & 19.13 & 0.000 & 21.19446 & 26.03326 \\
\hline
\end{tabular}




\section{CONSIDERAÇÕES FINAIS.}

Em 1944, quando as economias mais importantes à época reuniram-se em Bretton Woods para discutir os fundamentos da futura ordem financeira internacional do pósguerra, os delegados presentes estavam principalmente preocupados com três assuntos: a manutenção de taxas de câmbio estáveis para que o comércio internacional fluísse sem sobressaltos, a correção de desequilíbrios de conta corrente, e problemas relacionados com eventuais fuga de capitais. Desejava-se um mundo em que fortes controles de capital permanecessem, que as taxas câmbio se mantivessem fixas, e que as moedas se mantivessem atreladas a um padrão.

Nesse rígido (e idealizado) mundo, as políticas monetárias domésticas não produziriam externalidades, um país não seria afetado pela maneira como outro governo nacional gere sua moeda, ou cria incentivos para seu sistema financeiro. Esse foi o fundamento sobre o qual o FMI foi criado $^{222}$. Nesse mundo, haveria pouco espaço para integração de mercados, e os governos nacionais continuariam sendo soberanos sobre seus sistemas financeiros nacionais. Tampouco haveria a necessidade de cooperação internacional e criação de outras instituições financeiras.

Esse mundo não existe mais hoje, e muitos dizem que nunca existiu ${ }^{223}$. Como mostrado supra, por diversas razões e por meio de formatos múltiplos, desde a década de 1970 governos nacionais têm cooperado no sentido de construir instituições que permitiram a formação de mercados transfronteiriços, offshore e virtuais. A integração de mercados, chamada aqui de globalização, é uma realidade, e fluxos financeiros internacionais afetam os países ao redor do globo de formas cada vez mais significativas.

Dando suporte a esses fluxos está uma nascente malha jurídico-institucional que, acompanhando o crescimento da movimentação de capitais, também têm se tornado mais densa. Essa teia de acordos e instituições tem natureza diversa. Em relação à forma, é composta por tratados internacionais, regras harmonizadas, determinações supranacionais ou comunitárias, cooperação executiva, medidas domésticas. Em relação aos

${ }^{222}$ Vide (United Nations Monetary and Financial Conference 1944).

${ }^{223}$ Vide, por exemplo, um estudo clássico sobre o sistema de Bretton Woods, (Barry Eichengreen 2008c). 
participantes, têm-se acordos bilaterais, plurilaterais e multilaterais. Em relação aos setores abrangidos, refere-se aos setores bancário e mercado de capitais. A existência de quase nenhum destes tipos de acordos foi prevista ou considerada pelos fundadores do Sistema de Bretton Woods, e, em verdade, tais acordos surgiram muitas vezes sem coordenação alguma com instituições financeiras internacionais como o FMI.

O presente estudo teve dois objetivos. O primeiro (1) foi substantivo: contribuir com o debate sobre globalização financeira, ajudando a nele incorporar uma dimensão que parecia um pouco fora de foco em diversas discussões - a dimensão jurídicoinstitucional empírica. Existem duas razões para isso. A primeira é que, considerando-se a literatura revista e o alto nível das discussões suscitadas, ainda assim parece haver algumas idéias fora de lugar e falta de evidência empírica. A segunda é que esse debate, pensa-se, muitas vezes é feito na seara puramente normativa, e beneficiar-se-ia com um pouco mais de abordagens explicativas e certa sensibilidade institucional.

O segundo (2) era metodológico, e não se relaciona diretamente com o objeto da pesquisa: ajudar a incorporar ao estudo do direito no Brasil a utilização de certas técnicas empíricas que permitiriam o exercício mais freqüente do que se será chamado aqui de "ceticismo esclarecido pela empiria" - o salutar questionamento de afirmações doutrinais peremptórias com o auxílio de evidência empírica.

Sobre o objetivo (1) substantivo, a tese apresentada é uma reação a uma interpretação do fenômeno da globalização financeira que foi corrente durante a década passada e parecia dominante até a crise financeira de 2008. Grosso modo, a interpretação pode ser resumida da seguinte forma. A globalização financeira estaria sendo causada pela retração dos Estados Nacionais, que estavam se retirando da atividade regulatória, de forma geral, e regulação das finanças, de formas mais específicas. Num movimento generalizado e amplo, governos ao redor do mundo estariam sucumbindo às forças e benesses do mercado, permitindo que seus súditos tivessem acesso a finanças estrangeiras, e instituições financeiras internacionais adquirissem ativos financeiros nos mercados domésticos. Essa internacionalização das finanças, portanto, é produto da ausência de regulação e do movimento natural dos mercados.

Tal interpretação tem três componentes. O primeiro é a asserção de que, supostamente, evidência empírica demonstraria que a liberalização financeira unilateral 
geraria desenvolvimento: baseado em certos estudos fragmentários de casos bemsucedidos de liberalização financeira ocorridos principalmente na década de 1980, poderse-ia dizer que abertura da conta corrente estaria relacionada com crescimento do produto interno bruto. $\mathrm{O}$ segundo componente é a asserção de que existiria certa uniformidade nos motivos e homogeneidade nos resultados dos diversos processos de reformas financeiras ocorrendo ao redor do mundo, e essas uniformidade e homogeneidade estariam gerando a globalização financeira. O terceiro componente é uma derivação normativa dos outros dois na forma de generalização dessas asserções. Implica dizer que existiria um receituário de reformas liberalizantes, um programa, que poderia ser prescrito aos diversos países ao redor do mundo. Esse programa permitiria que os países se integrassem à onda globalizante e se beneficiassem.

Os capítulos da tese apresentada contrapõem-se a essa interpretação. Reconhecendo que a globalização financeira é um fato - fluxos financeiros aumentaram, e mercados financeiros estão em processo de integração em escala global -, a presente tese expõe uma interpretação alternativa para o fenômeno. Segundo o aqui sustentado, a globalização seria descentralizada na natureza e heterogênea nos resultados, produto de uma de uma série de mudanças institucionais que não necessariamente estariam articuladas. Tais transformações, foram geradas, não pela retração dos Estados, mas por uma série de programas e reformas institucionais, conjuntos de ações de governos nacionais visando a atingir diversos fins. Portanto, pela ativa persecução de objetivos de política pública por parte dos governos nacionais.

Nessa linha, a Parte I da tese adotou um tipo específico de metodologia de estudo de caso - a reconstrução histórico-institucional - para mostrar a importância perene dos governos nacionais na construção de mercados financeiros. O Capítulo 1 mostrou o vigoroso papel dos governos na formação de um arranjo que esta tese chamou de sistema financeiro nacional. Governos nacionais, buscando consolidar sua dominância sobre os mercados nacionais, e, na seqüência, tentando desenvolver instrumentos para a apoiar a industrialização, houveram por bem controlar fluxos financeiros internacionais e regular pesadamente o mercado financeiro. $\mathrm{O}$ resultado foi a formação de estruturas de mercado em que a propriedade dos ativos financeiros e das instituições operando em mercado doméstico pertencia, predominantemente, a nacionais. Esse arranjo foi dominante até 
meados dos anos 1970. Foram apresentados cinco casos de formação de sistemas financeiros nacionais: Inglaterra, França, Alemanha, Estados Unidos e Brasil.

O Capítulo 2 concentrou-se em mostrar como governos nacionais têm se engajado no que a tese chamou de processos de integração financeira. Sob tal rubrica, enquadramse diversos casos de criação de instituições internacionais, assinatura de acordos, e edição conjunta de normas visando a possibilitar a atuação transfronteiriça de instituições financeiras. Estudaram-se aqui os casos de cinco casos diferentes de processos de integração: a integração unilateral brasileira nos anos 1990; a formação do espaço financeiro europeu; o estabelecimento do acordo da Basiléia; a assinatura do acordo de serviços financeiros da OMC; a adoção do Memorando Multilateral de Entendimento no seio da IOSCO. Por motivos relacionados, seja com estratégias de modernização do setor financeiro, seja com combate a crises financeiras, governos nacionais têm patrocinado a construção desses novos arranjos internacionais e instituições. Tais novidades têm tornado, pouco a pouco, as fronteiras nacionais mais porosas. Conseqüentemente, o arranjo regulatório chamado sistema financeiro nacional, nascido principalmente no início do século XX vem modificando-se e acoplando-se a uma malha de acordos e regimes regulatórios internacionais. A globalização financeira é produto dessas modificações.

A Parte (II) do texto buscou complementar a análise dos dois capítulos anteriores abordando as transformações apontadas sob um prisma quantitativo. Tentou-se comparar os diferentes tipos de processos de integração, de forma a dimensionar seus determinantes e efeitos. Em muitos aspectos as conclusões do estudo quantitativo corroboram a análise histórico-institucional. A análise econométrica indicou que cada um dos diversos processos integradores estaria correlacionado a variáveis específicas. Padrões claros de relacionamento surgiram, indicando pluralidade de determinantes e conseqüências.

Como conclusão, pode-se dizer que a presente tese levanta diversos elementos que aqueles que sustentam a interpretação de que a globalização financeira está a ser gerada pela retração do Estado. As três asserções em que esta última estava baseada parecem ser pouco críveis pelos seguintes motivos. Em primeiro lugar, ao contrário do que qualquer evidência inicial possa ter levado a crer, (a) não parece haver um único 
objetivo o qual todos os processos o qual todos os processos de liberalização perseguem, e (b) há muita heterogeneidade nos resultados por eles conseguidos. Estudos mais contemporâneos, inclusive o presente, mostram que nem mesmo a evidência sobre a correlação entre abertura financeira e crescimento do produto interno bruto se sustenta.

Em segundo lugar, é visível na evidência coligida pela tese que a globalização financeira resulta de uma sobreposição de processos de integração financeira, variados em seus objetivos e em suas conseqüências. Tais processos têm natureza jurídica diversa, não podem ser inseridos em supostas lógicas unitárias, são bastante heterogêneos e envolvem múltiplas geometrias de participantes.

Em terceiro lugar, dada a diversidade de necessidades, formas e resultados, não poderia existir um programa único de reformas. No entanto, mesmo diante dessa pluralidade, é possível realizar estudos comparados e discutir soluções adotadas.. Integração financeira não é uma panacéia. Essa afirmação tem dois corolários interessantes. O primeiro, menos controverso, é o de que abertura pode, dependendo do contexto, ter efeitos positivos ou negativos sobre o crescimento econômico. O segundo, mais contra-intuitivo, é o de que, mesmo nos casos em que haja efeitos negativos sobre o crescimento do PIB, uma política de abertura pode ser adotada se o objetivo buscado pelo governo nacional não é primordialmente o crescimento econômico. 


\section{BIBLIOGRAFIA.}

Abbott, Philip, Thomas Barnebeck Andersen, and Finn Tarp. IMF and economic reform in developing countries. The Quarterly Review of Economics and Finance In Press, Corrected Proof. doi:10.1016/j.qref.2009.10.005. http://www.sciencedirect.com.monstera.cc.columbia.edu:2048/science/article/B6 W5X-4XH0MV6-2/2/564441127125965a10aa75b675e498f5.

Abiad, Abdul, Enrica Detragiache, and Thierry Tressel. 2008. A New Database of Financial Reforms. Working Paper. IMF Working Paper. Washington, D.C.: International Monetary Fund, December.

Adrian Richardson - RMIT Publishing - RMIT Training PTY LTD (http://www. rmitpublishing.com.au). 2006. Greater International Links in Banking Challenges for Banking Regulation. Economic Papers December, no. Special Issue (December): 111-120.

Aggarwal, Raj, and John W. Goodell. 2009. Markets and institutions in financial intermediation: National characteristics as determinants. Journal of Banking \& Finance 33, no. 10 (October): 1770-1780. doi:10.1016/j.jbankfin.2009.03.004.

Aizenman, Joshua, Menzie D. Chinn, and Hiro Ito. 2008. Assessing the Emerging Global Financial Architecture: Measuring the Trilemma's Configurations over Time. National Bureau of Economic Research Working Paper Series No. 14533 (December).

Alesina, A., V. Grilli, and G. M Milesi-Ferretti. 1994. The political economy of capital controls.

Allen, Franklin, and Douglas Gale. 2000. Financial Contagion. Journal of Political Economy 108, no. 1 (February 1): 1-33. doi:10.1086/262109.

Almeida, Manoel Luzardo de. 1992. Economia Brasileira. Ortiz.

Amsden, Alice H., and Yoon-Dae Euh. 1993. South Korea's 1980s financial reforms: Good-bye financial repression (maybe), hello new institutional restraints. World Development 21, no. 3. World Development: 379-390.

Amurgo Pacheco, Alberto. 2007. Mutual Recognition Agreements and Trade Diversion: Consequences for Developing Nations. Working Paper. Working Papers. Geneva: Graduate Institute of International Studies, April. http://econpapers.repec.org/paper/giigiihei/heiwp20-2006.htm.

Anaya, José Antonio González. 2003. Latin American macroeconomic reforms. University of Chicago Press.

Anon. United States v. Leon, 468 U.S. 897 (1984).

Armijo, Leslie Elliott. 2005. Mass democracy: The real reason that Brazil ended inflation? World Development 33, no. 12 (December): 2013-2027. doi:10.1016/j.worlddev.2005.05.011.

Armijo, Leslie Elliott, and Philippe Faucher. 2002. "We Have a Consensus": Explaining Political Support for Market Reforms in Latin America. Latin American Politics and Society 44, no. 2 (Summer): 1-40. 
Arrow, Kenneth J. 1969. The Organization of Economic Activity: Issues Pertinent to the Choice of Market versus Nonmarket Allocation. In 91st CongressThe Analysis and Evaluation of Public Expenditure: The PPB System, 1:59-73. Vol. 1. Washington, D.C.: U.S. Govt. Print. Off.

Ausubel, Lawrence M. 1991. The Failure of Competition in the Credit Card Market. The American Economic Review 81, no. 1 (March): 50-81. . 1999. Adverse Selection in the Credit Card Market. Working Paper. Maryland: University of Maryland, June 17.

Averbug, Andre. 2002. The Brazilian Economy in 1994-1999: From the Real Plan to Inflation Targets. The World Economy 25, no. 7: 925-944. doi:10.1111/14679701.00472.

Ayhan Kose, M., Eswar S. Prasad, and Marco E. Terrones. 2009. Does openness to international financial flows raise productivity growth? Journal of International Money and Finance 28, no. 4 (June): 554-580. doi:10.1016/j.jimonfin.2009.01.005.

Baldwin, Summerfield. 1968. Business in the middle ages. New York: Cooper Square Publishers.

Bank for International Settlements. 1999. The Core Principles Methodology. BCBS Publications. BCBS Publications. Basel: Bank for International Settlements, October.

—. 2001a. Core Principles for Systemically Important Payment Systems. CPSS Publications. CPSS Publications. Basel: Bank for International Settlements, January.

- 2001b. Recommendations for Securities Settlement Systems. CPSS Publications. CPSS Publications. Basel: Bank for International Settlements, November.

—. 2006. The Core Principles Methodology. BCBS Publications. BCBS Publications. Basel: Bank for International Settlements, October.

Bank of International Settlements. 2006. Implementation of the New Capital Adequacy Framework in Non-Basel Committee Member Countries. Working Paper. BIS Occasional Papers. Basle: Bank for International Settlements, September.

Bank, World, and International Monetary Fund. 2005. Financial sector assessment. World Bank Publications.

Barth, J. R, G. Caprio, and R. Levine. 2004. Bank regulation and supervision: what works best? Journal of Financial Intermediation 13, no. 2: 205-248.

Basel Committee on Banking Supervision. 1983. Principles for the Supervision of Banks' Foreign Establishments (the Concordat). Basle Committee on Banking Supervision, May 1.

- 1992. Minimum Standards for the Supervision of International Banking Groups and their Cross-border Establishments. Basle Committee on Banking Supervision, July 1.

Basle Committee on Banking Supervision (BCBS). 1988. International Convergence of Capital Measurement and Capital Standards. Basle: Basle Committee on Banking Supervision, July. . 2006. International Convergence of Capital Measurement and Capital Standards: A Revised Framework. Basle: Basle Committee on Banking Supervision, June. 
Beck, Thorsten, Juan Miguel Crivelli, and William Summerhill. State bank transformation in Brazil - choices and consequences. Journal of Banking \& Finance 29, no. 8-9 (August): 2223-2257. doi:10.1016/j.jbankfin.2005.03.014.

Bekaert, Geert, and Campbell R. Harvey. 2003. Emerging markets finance. Journal of Empirical Finance 10, no. 1-2 (February): 3-56. doi:10.1016/S09275398(02)00054-3.

Benink, Harald A. 1999. Europe's Single Banking Market. Journal of Financial Services Research 16, no. 2 (December 1): 319-322. doi:10.1023/A:1008113113955.

Bordo, Michael D. 2008. An Historical Perspective on the Crisis of 2007-2008. National Bureau of Economic Research Working Paper Series No. 14569 (December). http://www.nber.org/papers/w14569.

Bordo, Michael D., and Joseph G. Haubrich. 2009. Credit Crises, Money and Contractions: an historical view. National Bureau of Economic Research Working Paper Series No. 15389 (September). http://www.nber.org/papers/w15389.

Braithwaite, John, and Peter Drahos. 2000. Global Business Regulation. Cambridge University Press, February 13.

de Bruijn, R, H Kox, and A Lejour. 2008. Economic benefits of an Integrated European Market for Services. JOURNAL OF POLICY MODELING 30, no. 2 (April): 301319. doi:10.1016/j.jpolmod.2007.02.003.

Buonanno, L. 2006. The principle of mutual recognition in the European integration process. Journal of Common Market Studies 44, no. 5 (December): 1104-1105.

Burton, Maureen, and Raymond Lombra. 2005. The Financial System and the Economy. Thomson/South-Western, March 7.

Calvo, Guillermo A. 2005. Explaining Sudden Stops, Growth Collapse and BOP Crises: The Case of Distortionary Output Taxes. In Emerging Capital Markets in Turmoil: Bad Luck or Bad Policy? Cambridge, Mass: MIT Press.

Cameron, Rondo E., and Larry Neal. 2003. A Concise Economic History of the World: from Paleolithic Times to the Present. Oxford University Press US.

Carvalho, Carlos Eduardo. 2003. Bancos e inflação no Brasil: da crise dos anos 1980 ao Plano Real. In Carlos Eduardo Carvalho: PUC/SP Anais do V Congresso Brasileiro de História Econômica e $6^{a}$ Conferência Internacional de História de Empresas. Belo Horizonte: ABPHE, September 7. http://econpapers.repec.org/paper/abphe2003/056.htm.

Casas, F. R. 1983. International trade with produced transport services. Oxford Economic Papers 35, no. 1: 89-109.

Castro, Antônio Barros de, and Francisco Eduardo Pires de Souza. 1985. A Economia Brasileira em Marcha Forçada. Paz e Terra.

- 2004. A Economia Brasileira em Marcha Forçada. Paz e Terra.

Castro, Marcus Faro de, and Maria Izabel Valladao de Carvalho. 2003. Globalization and Recent Political Transitions in Brazil. International Political Science Review / Revue internationale de science politique 24, no. 4 (October): 465-490.

Chey, Hyoung-Kyu. 2007. Do markets enhance convergence on international standards? The case of financial regulation. Regulation \& Governance 1, no. 4: 295-311. doi:10.1111/j.1748-5991.2007.00020.x.

Claessens, Stijn, Geoffrey R. Underhill, and Xiaoke Zhang. 2008. The Political Economy of Basel II: The Costs for Poor Countries. The World Economy. 
Coffee, John C. 2007. Law and the Market: The Impact of Enforcement. Working Paper. Columbia Law School Working Paper Series. New York: Columbia Law School. SSRN. http://ssrn.com/paper=967482.

Coleman, William Donald. 1996. Financial Services, Globalization and Domestic Policy Change. Macmillan Press.

Commission of the European Communities. 1985. Completing the Internal Market: White Paper from the Commission to the European Council. Luxembourg: Office of Official Publications of the European Communities.

-1987. Communication of the Commission to the Council: Creation of a European Financial Area. November 4.

Commission of the European Union. 1998. Financial Services: Building a framework for action - Communication of the Commission. October 28.

-1999. Financial Services: Implementing the framework for financial markets: Action Plan - Communication of the Commission. May 11.

Committee on Trade in Financial Services. 1997. Trade in Services - Decision adopting the Fifth Protocol to the General Agreement on Trade in Services - Adopted by the Committee on Trade in Financial Services on 14 November 1997. S/L/44 (December 3).

Council of the European Communities. 1977. First Council Directive 77/780/EEC of 12 December 1977 on the coordination of laws, regulations and administrative provisions relating to the taking up and pursuit of the business credit institutions. December 12.

. 1989a. Council Directive 89/299/EEC of 17 April 1989 on the own funds of credit institutions. April 17. - 1989b. Second Council Directive 89/646/EEC of 15 December 1989 on the coordination of laws, regulations and administrative provisions relating to the taking up and pursuit of the business of credit institutions and amending Directive 77/780/EEC. December 15. . 1989c. Council Directive 89/647/EEC of 18 December 1989 on a solvency ratio for credit institutions. 89/647/EEC, O.J. L 386. December 18. . 1992. Council Directive 92/121/EEC of 21 December 1992 on the monitoring and control of large exposures of credit institutions. 92/121/EEC, O. J. L 029. December 21.

-1993. Council Directive 93/6/EEC of 15 March 1993 on the capital adequacy of investments firms and credit institutions. March 15.

Council of the European Union. 1998. Cardiff European Council - Presidency Conclusions. June 16.

Cysne, Rubens Penha. 1998. Aspectos Macro e Microeconômicos das Reformas Brasileiras. São Paulo: Graduate School of Economics, Getulio Vargas Foundation (Brazil), June. RePEc. http://ideas.repec.org/p/fgv/epgewp/328.html.

Daron Acemoglu and Simon Johnson. 2005a. Unbundling Institutions. Journal of Political Economy 113, no. 5. Journal of Political Economy: 949-995.

_. 2005b. Unbundling Institutions. Journal of Political Economy 113, no. 5. Journal of Political Economy: 949-995.

Davies, Glyn. 1994. A History of Money. University of Wales Press.

Demirguc-Kunt, Asli, and Enrica Detragiache. 2009. Basel Core Principles and Bank 
Soundness: Does Compliance Matter? Working Paper. Policy Research Working Paper. Washington, D.C.: World Bank, November.

Demirguc-Kunt, Asli, Enrica Detragiache, and Thierry Tressel. 2006. Banking on the principles : compliance with Basel Core Principles and bank soundness. The World Bank, June. RePEc. http://ideas.repec.org/p/wbk/wbrwps/3954.html. Demirguc-Kunt, Asli, and Ross Levine. 2008. Finance, Financial Sector Policies, and Long-Run Growth. January 1. SSRN. http://papers.ssrn.com/sol3/papers.cfm?abstract_id=1081783\&rec=1\&srcabs $=114$ 9111.

Dewatripont, Mathias, and Jean Tirole. 1994. The Prudential Regulation of Banks. The MIT Press, December 20.

Diamond, Douglas W., and Philip H. Dybvig. 1983. Bank Runs, Deposit Insurance, and Liquidity. Journal of Political Economy 91, no. 3 (January 1): 401. doi:10.1086/261155.

Diaz-Alejandro, Carlos F. 1981. Southern Cone Stabilization Plans. In Economic Stabilization in Developing Countries. Washington, D.C.: Brookings Institution Press.

Djajic, S., and H. Kierzkowski. 1995. Goods, services and trade. Bertil Ohlin: critical assessments 56, no. 221: 109.

Djankov, Simeon, Edward Glaeser, Rafael La Porta, Florencio Lopez-de-Silanes, and Andrei Shleifer. 2003. The new comparative economics. Journal of Comparative Economics 31, no. 4 (December): 595-619. doi:10.1016/j.jce.2003.08.005.

Dobson, Wendy, and Pierre Jacquet. 1998. Financial Services Liberalization in the WTO. Washington, D.C.: Institute for International Economics.

Dobson, Wendy, Jacquet Pierre, and Pierre Jacquet. 1998. Financial Services Liberalization in the WTO. Peterson Institute, June.

Dornbusch, R. 1998. Capital controls: an idea whose time is past. Should the IMF Pursue Capital-Account Convertibility: 20-27.

Drake, William J., and Kalypso Nicolaidis. 1992. Ideas, interests, and institutionalization:" trade in services" and the Uruguay Round. International Organization 46, no. 1: 37-100.

Edwards, Sebastian. 1989. On the Sequencing of Structural Reforms. National Bureau of Economic Research, Inc, October. RePEc. http://ideas.repec.org/p/nbr/nberwo/3138.html.

-2009. Sequencing of reforms, financial globalization, and macroeconomic vulnerability. Journal of the Japanese and International Economies 23, no. 2 (June): 131-148. doi:10.1016/j.jjie.2008.09.004.

Edwards, Sebastian, and Sweder van Wijnbergen. 1986. The Welfare Effects of Trade and Capital Market Liberalization. International Economic Review 27, no. 1 (February): 141-148.

Eichengreen, B., and M. Mussa. 1998. Capital account liberalization and the IMF. Finance and Development 35: 16-19.

Eichengreen, Barry. 2008a. Sui Generis EMU. National Bureau of Economic Research Working Paper Series No. 13740 (January). http://www.nber.org/papers/w13740. . 2008b. The European Economy since 1945: Coordinated Capitalism and Beyond. Princeton University Press, July 1. 
- 2008c. Globalizing Capital: A History of the International Monetary System. 2nd ed. Princeton: Princeton University Press, September 15.

Ellis, Howard Sylvester. 1969. The economy of Brazil. University of California Press. Erlanger, Howard S., Bryant Garth, Jane E. Larson, Elizabeth Ellen Mertz, Victoria Nourse, and David B. Wilkins. 2005. Is it Time for a New Legal Realism? Wisconsin Law Review 2005: 335-363.

Ethan Barnaby Kapstein. 1992. Between Power and Purpose: Central Bankers and the Politics of Regulatory Convergence. International Organization 46, no. 1 (Winter): 265-287.

Eun, Cheol S., and Jinsoo Lee. Mean-variance convergence around the world. Journal of Banking \& Finance In Press, Corrected Proof. doi:10.1016/j.jbankfin.2009.09.016. http://www.sciencedirect.com.monstera.cc.columbia.edu:2048/science/article/B6 VCY-4XB1T9B-2/2/e80ac5511472a837b9072d1d32d0e460.

European Economic Community. 1957. Treaty Establishing the European Economic Community. March 25. 1987. Single European Act. July 1.

European Parliament, and Council of the European Union. 2004. Directive 2004/39/EC of the European Parliament and of the Council of 21 April 2004 on markets in financial instruments amending Council Directives 85/611/EEC and 93/6/EEC and Directive 2000/12/EC of the European Parliament and of the Council and repealing Council Directive 93/22/EEC. April 30.

European Union. 1992. Treaty on European Union. February 7.

Falvey, Rod, and Cha Dong Kim. 1992. Timing and Sequencing Issues in Trade Liberalisation. The Economic Journal 102, no. 413 (July): 908-924.

Feketekuty, Geza. 1988. International Trade in Services: An Overview and Blueprint for Negotiations. Cambridge, Massachusetts: Ballinger Publishing Company.

Fischer, S. 1998. Capital Account Liberalization and the Role of the IMF. Working Paper. Princeton Essays in International Finance. Princeton: University Of Princeton. Google Scholar.

Franco, Gustavo H. B. 1995. O Plano Real e Outros Ensaios. Rio de Janeiro: Editora Francisco Alves.

Freixas, Xavier, and Jean-Charles Rochet. 2008. Microeconomics of Banking. 2nd ed. The MIT Press, April 30.

Genn, Dame Hazel, Martin Partington, and Sally Wheeler. 2006. Law in the Real World. London: The Nuffield Foundation. http://www.ucl.ac.uk/news/newsarticles/0611/06110704.

Georgakopoulos, Nicholas L. 2005. Principles and Methods of Law and Economics: Enhancing Normative Analysis. Cambridge, Mass: Cambridge University Press, October 10.

Germain, Randall D. 1997. The International Organization of Credit. Cambridge University Press.

Giambiagi, Fábio, and André Arruda Villela. 2005. Economia Brasileira Contemporânea. Elsevier, Editora Campus.

Goldberg, Linda S. 2009. Understanding Banking Sector Globalization. IMF Staff Papers 56, no. 1 (2): 171-197. doi:10.1057/imfsp.2008.31. 
Goldstein, M. 2000. Strengthening the international financial architecture: where do we stand? In . Honolulu, August 10.

Gore, Charles. 2000. The Rise and Fall of the Washington Consensus as a Paradigm for Developing Countries. World Development 28, no. 5 (May): 789-804. doi:10.1016/S0305-750X(99)00160-6.

Gottschalk, R. 2000. Sequencing Trade and Capital Account Liberalisation: The Experience of Brazil in the 1990s. Working Paper. Occasional Paper. Geneva: UNCTAD/UNDP. Google Scholar.

Government of the United States of America, and Government of Switzerland. 1982. Memorandum of Understanding concerning the exchange of information between the Government of the United States of America and the Government of Switzerland. August 31.

Griffiths, Brian. 1975. Invisible barriers to invisible trade. Trade Policy Research Centre. Grilli, Vittorio, and Gian Maria Milesi-Ferretti. 1995. Economic Effects and Structural Determinants of Capital Controls. Staff Papers - International Monetary Fund 42 , no. 3 (September): 517-551.

Gup, Benton E. 2004. Insights from a Global Survey on Bank Capital. SSRN eLibrary (April). http://papers.ssrn.com/sol3/papers.cfm?abstract_id=555995.

Heise, Michael. 2002. Empirical And Experimental Methods Of Law: The Past, Present, And Future Of Empirical Legal Scholarship: Judicial Decision Making And The New Empiricism. University of Illinois Law Review 2002: 819-850.

Hellwig, M. 1991. Banking, Financial Intermediation and Corporate Finance. In European Financial Integration. Cambridge, UK: Cambridge University Press.

Helpman, Elhanan, and Paul Krugman. 1987. Market Structure and Foreign Trade: Increasing Returns, Imperfect Competition, and the International Economy. The MIT Press, February 6.

Henry, Peter Blair. 2007. Capital account liberalization: Theory, evidence, and speculation. Journal of Economic Literature 45, no. 4: 887-935.

Hermann, Jennifer. 2002. Financial Structure and Financing Models: The Brazilian Experience over the 1964-1997 Period. Journal of Latin American Studies 34, no. 1 (February): 71-114.

Ho, Daniel E. 2002. Compliance and International Soft Law: Why Do Countries Implement the Basle Accord? J Int Economic Law 5, no. 3 (August 1): 647-688. doi:10.1093/jiel/5.3.647.

Holdsworth, Sir William Searle, and Edward Potton. 1937. A History of English Law. London: Methuen.

Horwitz, Morton J. 2006. The Transformation of American Law, 1780-1860. Cambridge, Mass: Harvard University Press, August 20.

Hoxha, Indrit, Sebnem Kalemli-Ozcan, and Dietrich Vollrath. 2009. How Big are the Gains from International Financial Integration? National Bureau of Economic Research Working Paper Series No. 14636 (January). http://www.nber.org/papers/w14636.

Interim Group on Financial Services. 1994. Communication from Japan and the United States: Measures by the Government of the United States and the Government of Japan Regarding Insurance. S/IGFS/W/1 (October 24).

International Monetary Fund. 1999. Code of Good Practices on Transparency in 
Monetary and Financial Policies: Declaration of Principles. Washington, D.C.: International Monetary Fund, September 26. . 2000. Offshore Financial Centers - IMF Background Paper. Background Paper. Washington, D.C.: International Monetary Fund.

International Organization of Securities Commissions. 1991. Principles of Memoranda of Understanding (MoU). Setember 1, 1991: International Organization of Securities Commissions. 1994. International Organization of Securities Commissioners, Resolution on Commitment to Basic IOSCO Principles of High Regulatory Standards and Mutual Cooperation and Assistance. International Organization of Securities Commissions, October. . 1998a. Objectives and Principles of Securities Regulation, Report of IOSCO. Report. International Organization of Securities Commissions, September. . 1998b. Resolution on Principles for Record Keeping, Collection of Information, Enforcement Powers and Mutual Cooperation to Improve the Enforcement of Securities and Futures Laws. International Organization of Securities Commissions, October 1. 2002. IOSCO Multilateral MOU, IOSCO Report. International Organization of Securities Commissions, May.

Jarreau, J. S. 1999. Interpreting the General Agreement on Trade in Services and the WTO instruments relevant to the international trade of financial services: the lawyer's perspective. NCJ Int'l L. \& Com. Reg. 25: 1.

Jefferson, ThomasLetter. 1816. Letter from Thomas Jefferson to John Taylor, 26 May 1816. May 26.

Jensen, Michael C., and William H. Meckling. 1976. Theory of the firm: Managerial behavior, agency costs and ownership structure. Journal of Financial Economics 3, no. 4. Journal of Financial Economics: 305-360.

Jones, R. W, and F. Ruane. 1990. Appraising the options for international trade in services. Oxford Economic Papers 42, no. 4: 672-687.

Joskow, P. L, and R. G Noll. 1999. The Bell Doctrine: Applications in Telecommunications, Electricity, and Other Network Industries. Stanford Law Review 51, no. 5.

Kalemli-Ozcan, Sebnem, Elias Papaioannou, and José-Luis Peydró. 2009. What Lies Beneath the Euro's Effect on Financial Integration: Currency Risk, Legal Harmonization, or Trade? National Bureau of Economic Research Working Paper Series No. 15034 (June). http://www.nber.org/papers/w15034.

Kaminsky, Graciela Laura, and Sergio L. Schmukler. 2002. Short-run pain, long-run gain : the effects of financial liberalization. Working Paper. Policy Research Working Paper. Washington, D.C.: The World Bank, October. RePEc. http://ideas.repec.org/p/wbk/wbrwps/2912.html.

Kapstein, Ethan. 2006. Architects of Stability? International Cooperation among Financial Supervisors. Working Paper. Working Papers. Basle: Bank for International Settlements, February.

Kasman, A, S Kirbaskasman, and E Turgutlu. 2008. Monetary policy convergence of potential EMU accession countries: A cointegration analysis with shifting regimes. Economic Modelling 25, no. 2 (3): 340-350. 
doi:10.1016/j.econmod.2007.06.004.

Key, Sydney J. 1989. Financial integration in the European Community. Board of Governors of the Federal Reserve System (U.S.). RePEc. http://ideas.repec.org/p/fip/fedgif/349.html.

Keynes, John Maynard. 1933. National self-sufficiency. The Yale Review 22, no. 4 (June): 755-769.

Kindleberger, Charles P. 1984. A Financial History of Western Europe. Taylor \& Francis.

King, Robert G., and Ross Levine. 1993a. Finance, entrepreneurship and growth: Theory and evidence. Journal of Monetary Economics 32, no. 3. Journal of Monetary Economics: 513-542.

. 1993b. Finance and Growth: Schumpeter Might be Right. The Quarterly Journal of Economics 108, no. 3 (August): 717-737.

Kireyev, Alexei. 2002. Liberalization of Trade in Financial Services and Financial Sector: Stability Analytical Approach. SSRN eLibrary (August).

Klein, M. W, and G. P Olivei. 2008. Capital account liberalization, financial depth, and economic growth. Journal of International Money and Finance 27, no. 6: 861875.

Klemperer, P. 1987a. The competitiveness of markets with switching costs. The RAND Journal of Economics: 138-150.

- 1987b. Markets with consumer switching costs. The Quarterly Journal of Economics 102, no. 2: 375-394.

Klerman, Daniel, and Paul G. Mahoney. 2007a. Legal origin? Journal of Comparative Economics 35, no. 2 (June): 278-293. doi:10.1016/j.jce.2007.03.007.

- 2007b. Legal origin? Journal of Comparative Economics 35, no. 2 (June): 278293. doi:10.1016/j.jce.2007.03.007.

Kose, M. Ayhan, Eswar Prasad, Kenneth S. Rogoff, and Shang-Jin Wei. 2006. Financial Globalization: A Reappraisal. Working Paper. NBER Working Paper. NBER, August. National Bureau of Economic Research.

Krugman, Paul. 2008. The Return of Depression Economics and the Crisis of 2008. W. W. Norton, December 1.

Krugman, Paul R., Maurice Obstfeld, and Addison Wesley. 2008. International Economics: Theory and Policy. International edition. Pearson Education Limited, July 3.

Kuhn, Thomas S. 1961. The Function of Measurement in Modern Physical Science. Isis 52, no. 2 (January 1): 161-193. doi:10.1086/349468.

Lagoarde-Segot, Thomas. 2009. Financial reforms and time-varying microstructures in emerging equity markets. Journal of Banking \& Finance 33, no. 10 (October): 1755-1769. doi:10.1016/j.jbankfin.2009.01.007.

Lardy, Nicholas R. 2008. Financial Repression in China. Policy Paper. Policy Brief in International Economics. Washington, D.C.: Peterson Institute for International Economics, September.

Lee, Tan Chong. 1989. International Convergence of Capital Measurement and Capital Standards for Banks. Reserve Bank Bulletin 52, no. 1: 37-43.

Lemmen, Jan, and Sylvester Eijffinger. 1996. The fundamental determinants of financial integration in the European Union. Review of World Economics 132, no. 3: 432- 
456. doi:10.1007/BF02707507.

Leroux, Eric H. 2002. Trade in financial services under the World Trade Organization. Journal of World Trade 36, no. 3: 413-442.

Lorenzo-Fernández, O. S. 1980. A Evolução da Economia Brasileira. Zahar Editores.

Lundberg, Eduardo. 1999. Saneamento do Sistema Financeiro - A Experiência Brasileira dos Últimos 25 Anos. In Intervenção e Liquidação Extrajudicial no Sistema Financeiro Nacional - 25 Anos da Lei 6.024/74, 53-70. São Paulo: Textonovo.

Macaulay, Stewart. 2005. The New versus the Old Legal Realism: 'Things Ain't What They Used to Be'. Wisconsin Law Review 2005, no. 2: 365-403.

Mann, Michael D., and William P. Barry. 2005. Developments in the Internationalization of Securities Enforcement. International Law 29: 667.

Marangos, John. 2009. What happened to the Washington Consensus? The evolution of international development policy. Journal of Socio-Economics 38, no. 1 (January): 197-208. doi:10.1016/j.socec.2008.07.007.

Marczyk, Geoffrey R., David DeMatteo, and David Festinger. 2005. Essentials of Research Design and Methodology. 1st ed. New York: Wiley, March 2.

van Marrewijk, C., J. Stibora, and A. de Vaal. 1996. Services tradability, trade liberalization and Foreign Direct Investment. Economica 63, no. 252: 611-631.

Martins, Ivan Pedro de. 1961. Introdução à Economia Brasileira. J. Olympio.

Mattoo, A., R. Rathindran, and A. Subramanian. 2006. Measuring services trade liberalization and its impact on economic growth: An illustration. Journal of Economic Integration 21, no. 1: 64-98.

McKinnon, R. I. 1973. Money and capital in economic development. Brookings Institution Press.

McKinnon, Ronald I. 1981. Southern Cone Stabilization Plans. Comments. In Economic Stabilization in Developing Countries. Washington, D.C.: Brookings Institution Press.

- 1991. Financial Control in the Transition from Classical Socialism to a Market Economy. The Journal of Economic Perspectives 5, no. 4 (Autumn): 107-122.

Meerschwam, David M. 1991. Breaking Financial Boundaries. Harvard Business School Press.

de Mello, J. M. 2003. Market power and the availability of credit: an empirical investigation of the small firms' credit market. Stanford University, mimeo.

Miles, Thomas J., and Cass R. Sunstein. 2008. The New Legal Realism. University of Chicago Law Review 75 (Spring): 831-851.

Mirandola, Carlos Mauricio. 2006. Normas Sobre o Comércio Internacional de Serviços na OMC e Regulação Financeira. Dissertação de Mestrado, São Paulo: University of São Paulo, December.

Mishkin, Frederic. 2005. Is Financial Globalization Beneficial? National Bureau of Economic Research Working Paper Series No. 11891 (December). http://www.nber.org/papers/w11891.

Mishkin, Frederic S. 2009. Globalization and financial development. Journal of Development Economics 89, no. 2 (July): 164-169. doi:10.1016/j.jdeveco.2007.11.004.

Mollo, Maria de Lourdes Rollemberg, and Alfredo Saad-Filho. 2006. Neoliberal economic policies in Brazil (1994-2005): Cardoso, Lula and the need for a 
democratic alternative. New Political Economy 11, no. 1: 99.

doi:10.1080/13563460500494933.

Moran, Michael. 1986. The Politics of Banking: The Strange Case of Competition and Credit Control. Macmillan, January 1.

1991. The Politics of the Financial Services Revolution. Macmillan.

Morgan, Edward Victor. 1965. The theory and practice of central banking, 1797-1913. CUP Archive.

Mosley, Layna. 2003. Attempting Global Standards: National Governments, International Finance, and the IMF's Data Regime. Review of International Political Economy 10, no. 2 (May): 331-362.

Moura, Alkimar Ribeiro. 2007. PAEG e Real. FGV Editora.

Multilateral Trade Negotiations, Trade Negotiations on Services. 1991. Services Sectoral Classification List: A Note by the Secretariat. MTN.GNS/W/120 (July 10).

Neuhaus, Paulo. 1980. Economia Brasileira: Uma Visão Histórica. Editora Campus.

Obadan, Mike I. 2006. Globalization of finance and the challenge of national financial sector development. Journal of Asian Economics 17, no. 2 (April): 316-332. doi:10.1016/j.asieco.2005.11.002.

Obstfeld, Maurice. 1998. The Global Capital Market: Benefactor or Menace? The Journal of Economic Perspectives 12, no. 4 (Autumn): 9-30.

- 2009. International Finance and Growth in Developing Countries: What Have We Learned? National Bureau of Economic Research Working Paper Series No. 14691 (February). http://www.nber.org/papers/w14691.

Obstfeld, Maurice, and Alan M. Taylor. 2004. Global capital markets. Cambridge University Press.

Osborne, Robin. 1993. Banking. In Financial Services in the New Europe, 4-41. London: Graham \& Trotman/M. Nijhoff.

Paula, Luis Fernando R. 2004. Determinantes e Impactos da Recente Entrada de Bancos Europeus no Brasil. Revista de Economia 30, no. 2: 35-77.

Paula, Luis Fernando R., and Maria Beatriz Leme Marques. 2006. Tendências recentes da consolidação bancária no Brasil. Análise Econômica 24, no. 45: 235-263.

Paula, Luiz Fernando de. 1998. Tamanho, dimensão e concentração do sistema bancário no contexto de alta e baixa inflação no Brasil. Nova Economia 8, no. 1: 87-116.

Peláez, Carlos Manuel. 1987. Economia Brasileira Contemporânea: Origens e Conjuntura Atual. Editora Atlas.

Pinheiro, Armando Castelar, Fábio Giambiagi, and Maurício Mesquita Moreira. 2001. $O$ Brasil na Década de 90: Uma Transição Bem-Sucedida? Discussion Paper. Texto Para Discussão. Rio de Janeiro: Banco Nacional de Desenvolvimento Economico e Social, November.

Pistor, Katharina, and Chenggang Xu. 2004. Incomplete Law. Journal of International Law and Politics: 931-1013.

- 2005. Governing emerging stock markets: legal vs administrative governance. American Law and Economics Review 114, no. 1 (January): 366-402.

Prado Júnior, Caio. 1963. História económica do Brasil. Editora Brasilense.

Prasad, E. S, and R. G Rajan. 2008. A pragmatic approach to capital account liberalization. Journal of Economic Perspectives 22, no. 3: 149-172.

Prasad, E. S, R. G Rajan, and A. Subramanian. 2007. Foreign capital and economic 
growth. Brookings Papers on Economic Activity 1: 153.

Productivity Commission. 2004. Evaluation of the Mutual Recognition Schemes. EconWPA, February. RePEc. http://ideas.repec.org/p/wpa/wuwpmi/0402002.html.

Purcell, Susan Kaufman, and Riordan Roett. 1997. Brazil under Cardoso. Lynne Rienner Publishers.

Roberts, Richard. 1994. Offshore Financial Centres. Edward Elgar Publishing, March. Rodrik, Dani, and Arvind Subramanian. 2009. Why Did Financial Globalization Disappoint? IMF Staff Papers 56, no. 1 (1): 112-138. doi:10.1057/imfsp.2008.29.

Roe, Mark J. 2008. Legal Origins and Modern Stock Markets. Discussion Paper. Harvard Law and Economics Discussion Paper. Cambridge, Mass: Harvard Law School. SSRN. http://ssrn.com/paper=908972.

Roe, Mark J., and Jordan I. Siegel. Finance and Politics: A Review Essay Based on Kenneth Dam's Analysis of Legal Traditions in the Law-Growth Nexus. SSRN eLibrary. http://papers.ssrn.com/sol3/papers.cfm?abstract id=1476043.

Rogoff, Kenneth. 1999. International Institutions for Reducing Ḡobal Financial Instability. National Bureau of Economic Research Working Paper Series No. 7265 (July). http://www.nber.org.monstera.cc.columbia.edu:2048/papers/w7265.

Samuels, David. 2003. Fiscal Straitjacket: The Politics of Macroeconomic Reform in Brazil, 1995-2002. Journal of Latin American Studies 35, no. 3 (August): 545569.

Scott, Hal S. 2005. An Overview of International Finance: Law and Regulation. SSRN eLibrary (December 15).

http://papers.ssrn.com/sol3/papers.cfm?abstract_id=800627\&rec=1\&srcabs $=1105$ 740 .

- 2008. International Finance: Transactions, Policy and Regulation. 15th ed. Foundation Press, July 28.

Scott, Hal S., and Philip A. Wellons. 2002. Cases on International Securities Regulation. Foundation Press.

Shaffer, Gregory. 2002. Managing U.S.-EU Trade Relations Through Mutual Recognition and Safe Harbor Agreements: 'New' and 'Global' Approaches to Transatlantic Economic Governance? Columbia Journal of European Law 9: 2977.

Simmons, Beth A. 2001. The International Politics of Harmonization: The Case of Capital Market Regulation. International Organization 55, no. 03: 589-620. doi:10.1162/00208180152507560.

_ 2006a. The Future of Central Bank Cooperation. SSRN eLibrary (February). http://papers.ssrn.com/sol3/papers.cfm?abstract_id=891920.

- 2006b. The Future of Central Bank Cooperation. Working Paper. Working Papers. Basle: Bank for International Settlements, February.

Singer, David Andrew. 2004. Capital Rules: The Domestic Politics of International Regulatory Harmonization. International Organization 58, no. 03: 531-565. doi:10.1017/S0020818304583042.

- 2007. Regulating Capital: Setting Standards for the International Financial System. illustrated edition. Cornell University Press, July.

Sodré, Nelson Werneck. 1967. História da Burguesia Brasileira. Civilização Brasileira. 
Spong, Kenneth. 2000. Banking Regulation Its Purposes, Implementation, and Effects.

Stiglitz, J. E. 2000. Capital market liberalization, economic growth, and instability. World development 28, no. 6: 1075-1086.

Strange, Susan. 1996. The Retreat of the State: The Diffusion of Power in the World Economy. Cambridge University Press, November 13.

Studart, Rogério. 1995. Investment finance in economic development. Routledge.

Stulz, René M. 2005. The Limits of Financial Globalization. The Journal of Finance 60, no. 4 (8): 1595-1638. doi:10.1111/j.1540-6261.2005.00775.x.

Tarbert, Heath Price. 2000. Are International Capital Adequacy Rules Adequate? The Basle Accord and beyond. University of Pennsylvania Law Review 148, no. 5 (May): 1771-1849.

Tarullo, Daniel K. 2008. Banking on Basel: The Future of International Financial Regulation. 1st ed. Peterson Institute, September 30.

Trachtman, Joel P. 2006. Embedding Mutual Recognition at the WTO. SSRN eLibrary (August 11). http://papers.ssrn.com/sol3/papers.cfm?abstract_id=923903.

U.S. International Trade Commission. 1993. GATT: Uruguay Round Agreement is Reached; Clinton Notifies Congress Under Fast Track. International Trade Report, December 15.

Umutlu, Mehmet, Levent Akdeniz, and Aslihan Altay-Salih. 2009. The degree of financial liberalization and aggregated stock-return volatility in emerging markets. Journal of Banking \& Finance In Press, Corrected Proof. doi:10.1016/j.jbankfin.2009.08.010. http://www.sciencedirect.com.monstera.cc.columbia.edu:2048/science/article/B6 VCY-4X1SBBC-1/2/05416ffc18a6ca33078da8ba6b3cc7f0.

United Nations Monetary and Financial Conference. 1944. Final Act and Related Documents. U.S. Dept. of State no. 55. Washington: U.S. Govt. print. off.

Vo, Xuan Vinh, and Kevin James Daly. 2007. The determinants of international financial integration. Global Finance Journal 18, no. 2: 228-250. doi:10.1016/j.gfj.2006.04.007.

White, William R. 1996. International Agreements in the Area of Banking and Finance: Accomplishments and Outstanding Issues. SSRN eLibrary (October). http://papers.ssrn.com/sol3/papers.cfm?abstract_id=860607.

Williamson, J. 1990. What Washington Means by Policy Reform. In Latin American Adjustment: How Much Has Happened, 1: Vol. 1. Washington, D.C.: Institute for International Economics.

World Trade Organization. 1994. General Agreement on Trade in Services. LT/UR/A1B/S/1 (April 15).

- 1996. Singapore Ministerial Declaration. WT/MIN(96)/DEC (December 13). 1997. Fifth Protocol to the General Agreement on Trade in Services. $S / L / 45$ (December 3).

World Trade Organization, Council on Trade in Services. 1995. Decision on the Application of the Second Annex on Financial Services Adopted by the Committee on Trade in Financial Services on 30 June 1995. S/L/6 (July 4).

- 2001. Guidelines and Procedures for the Negotiations on Trade in Services, Adopted by the Special Session of the Council for Trade in Services on 28 March 2001. S/L/29 (March 28). http://www.wto.org/english/tratop_e/serv_e/s193.doc. 
World Trade Organization, Council on Trade in Services, Committee on Trade in Financial Services. 1995a. Report on the Meeting Held on 19 June 1995: Note by the Secretariat. S/FIN/M/4 (June 7).

- 1995b. Report on the Meeting Held on 29 June 1995: Note by the Secretariat. S/FIN/M/5/Rev.1 (June 29).

- 1995c. Report on the Meeting Held on 30 June 1995: Note by the Secretariat. S/FIN/M/6 (July 7).

. 1995d. Report on the Meeting Held on 21 July 1995: Note by the Secretariat. S/FIN/M/7 (July 26).

- 1997a. Report on the Meeting Held on 10 April 1997: Note by the Secretariat. S/FIN/M/13 (April 19).

-1997b. Report on the Meeting Held on 17 October 1997: Note by the Secretariat. S/FIN/M/17 (November 5).

- 1997c. Report on the Meeting Held on 12 and 14 November 1997: Note by the Secretariat. $S / F I N / M / 18$ (November 21).

—. 1997d. Report on the Meeting Held on 8 December 1997: Note by the Secretariat. $S / F I N / M / 19$ (December 17).

- 1997e. Report on the Meeting Held on 12 December 1997: Note by the Secretariat. S/FIN/M/20 (December 19). 